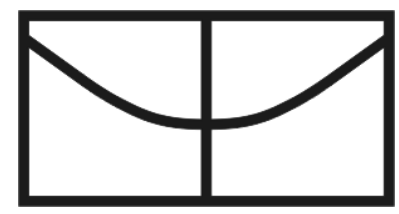

Universidade de Brasília

Instituto de Psicologia

Departamento de Processos Psicológicos Básicos

Programa de Pós-Graduação em Ciências do Comportamento

Comportamento de gestores de recursos públicos: identificação de contingências previstas e vigentes relativas à prestação de contas

Adriana de Oliveira

Orientador: Prof. Dr. Jorge Mendes de Oliveira Castro Neto

Brasília, novembro de 2016 


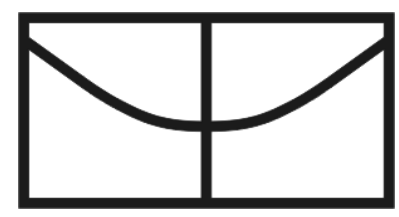

Universidade de Brasília

Instituto de Psicologia

Departamento de Processos Psicológicos Básicos

Programa de Pós-Graduação em Ciências do Comportamento

\title{
Comportamento de gestores de recursos públicos: identificação de contingências previstas e vigentes relativas à prestação de contas
}

\author{
Adriana de Oliveira
}

Orientador: Prof. Jorge Mendes de Oliveira Castro Neto, PhD

Tese apresentada ao Programa de PósGraduação em Ciências do Comportamento, Instituto de Psicologia, Área de Concentração Análise do Comportamento, como parte dos requisitos para obtenção do grau de Doutor em Psicologia.

Brasília, novembro de 2016 


\section{Comissão Examinadora}

A Banca Examinadora foi composta por:

Prof. Dr. Jorge Mendes de Oliveira-Castro Neto (Presidente)

Universidade de Brasília- UnB

Prof. Dr. Julio Cesar de Aguiar (Membro Efetivo)

Universidade Católica de Brasília - UCB

Profa. Dra. Eileen Pfeiffer Flores (Membro Efetivo)

Universidade de Brasília - UnB

Prof. Dr. Márcio Borges Moreira (Membro Efetivo)

Centro Universitário de Brasília - UniCeub

Prof. Dr. Lauro Eugênio Guimarães Nalini (Membro Efetivo)

Pontifícia Universidade Católica de Goiás - UCG

Profa. Dr. Fábio Henrique Granja e Barros (Membro Suplente)

Tribunal de Contas da União - TCU 


\section{Agradecimentos}

A Deus, por se fazer real todos os dias na minha vida e por me levar além do que um dia imaginei que seria possível.

Agradeço aos meus pais, pelo apoio e incentivo aos meus estudos desde os meus primeiros anos de vida e nessa etapa tão importante. Agradeço também aos meus irmãos e as minhas sobrinhas, pelo carinho e suporte em todos os momentos.

Aos meus amigos, por compreenderem a minha ausência e por me incentivarem a continuar. Aos colegas de doutorado, pelas contribuições, discussões e ideias, por me ajudarem nos detalhes que tornaram possível a conclusão deste trabalho. Aos meus colegas, Paulo e Ariela, por ouvirem os lamentos e me ajudarem na caminhada de quase 7 anos na UnB.

Ao meu orientador, Professor Jorge M. Oliveira-Castro Neto pelas contribuições teóricas valiosas, pelas discussões e orientações, pelo suporte e pela revisão atenta da tese. Agradeço em especial ao Professor Julio Cesar Aguiar pela rica contribuição e ensino sobre a Análise Comportamental do Direito, sem esse suporte, esse trabalho não teria sido realizado.

Agradeço à CAPES, pelo apoio financeiro concedido, à Universidade de Brasília, ao Instituto de Psicologia e ao Departamento de Processos Psicológicos Básicos.

Agradeço aos professores Julio Cesar de Aguiar, Márcio Borges Moreira, Eileen Pfeiffer Flores, Lauro Eugênio Guimarães Nalini e Fábio Henrique Granja e Barros por prontamente aceitarem compor minha banca examinadora.

Por fim, agradeço a todos que fizeram parte da minha vida durante esses anos e que me trouxeram tantas alegrias em meio às minhas ansiedades. 


\section{Sumário}

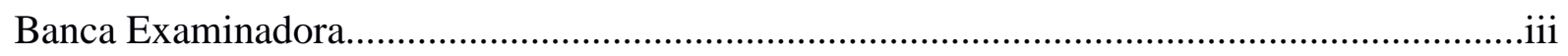

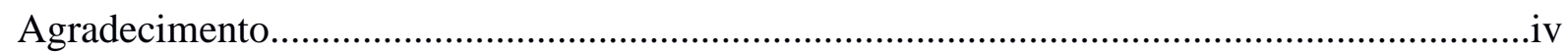

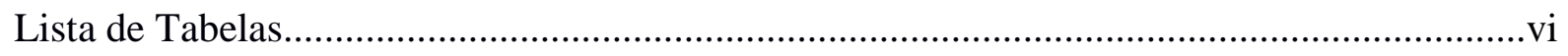

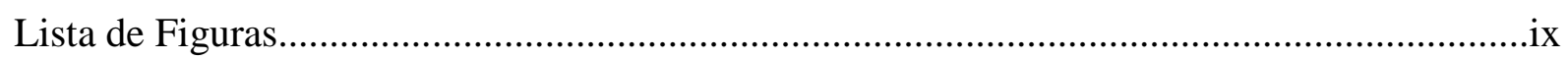

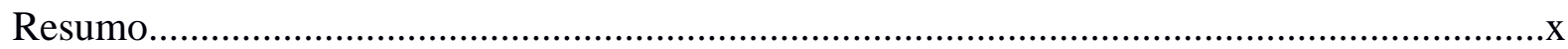

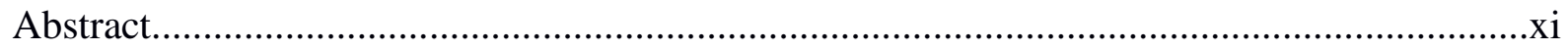

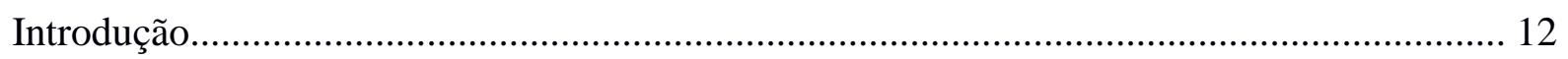

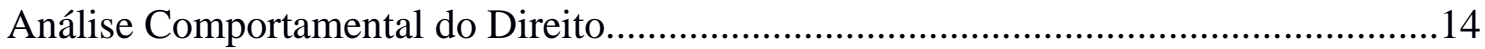

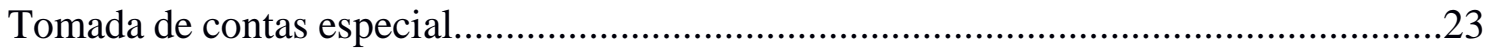

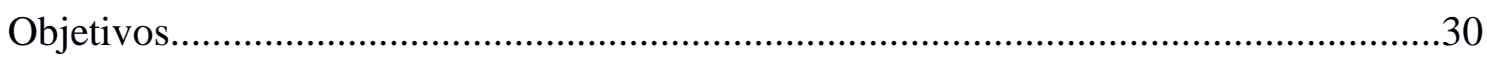

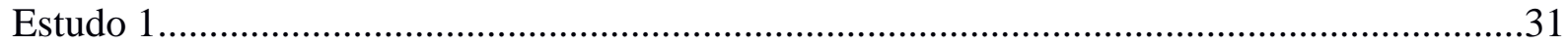

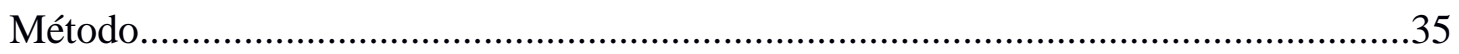

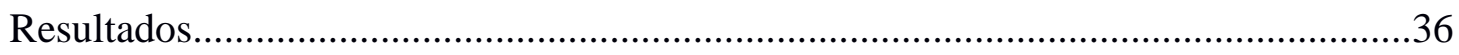

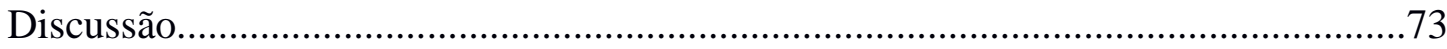

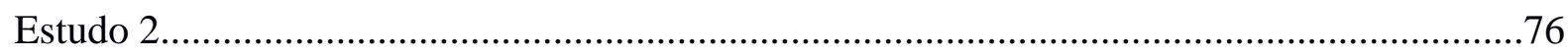

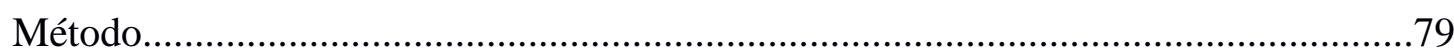

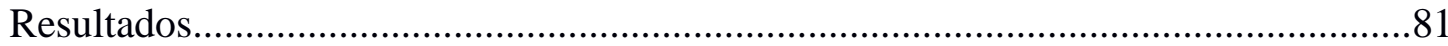

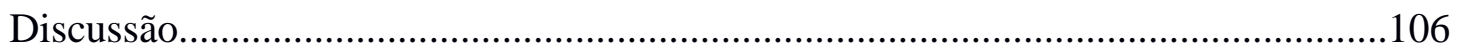

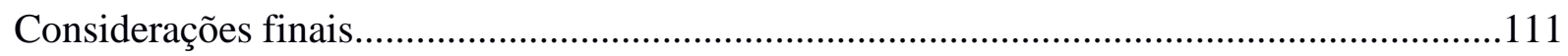

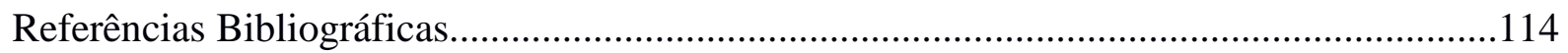

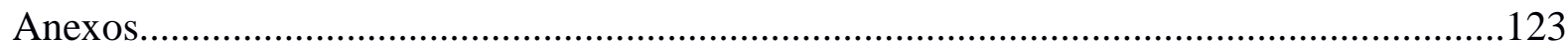




\section{Lista de Tabelas}

Tabela 1. Fluxograma da instauração de uma TCE. .26

Tabela 2. Análises de processos de tomada de contas especial (TCE) efetuadas pela CGU

Tabela 3. Norma jurídica e contingência jurídica no art. 8 da Lei $n^{\circ} 8.443 / 92$ para os responsáveis de recursos públicos e autoridades administrativas .57

Tabela 4. Contingência jurídica no art. 18 e art. 57 da Lei n ${ }^{\circ}$ 8.443/92 para os responsáveis de recursos públicos, autoridades administrativas e controle interno. .59

Tabela 5. Contingência jurídica no art. 51 da Lei $n^{\circ} 8.443 / 92$ e incisos 1 e 2 referente ao controle interno.

Tabela 6. Contingência jurídica no art. 58 da Lei n ${ }^{\circ} 8.443 / 92$ e incisos 1 e 2 referente ao controle interno.

Tabela 7. Contingência jurídica no art. 60 da Lei $n^{\circ} 8.443 / 92$ e responsável pelo uso do recurso

Tabela 8. Contingência jurídica no art. 197 do Regimento Interno do TCU, destinada à autoridade administrativa.

Tabela 9. Contingência jurídica no art. 210 e 267 do Regimento Interno do TCU, ao responsável pelo uso do recurso.

Tabela 10. Contingência jurídica no art. 214 do Regimento Interno do TCU, ao responsável pelo uso do recurso.

Tabela 11. Contingência jurídica no art. 219 do Regimento Interno do TCU, ao responsável pelo uso do recurso.

Tabela 12. Contingência jurídica no art. 268 do Regimento Interno do TCU, ao responsável pelo uso do recurso.

Tabela 13. Contingência jurídica no art. 270 do Regimento Interno do TCU, ao responsável pelo uso do recurso.

Tabela 14. Contingência jurídica no art. 271 do Regimento Interno do TCU, ao responsável pelo uso do recurso.

Tabela 15. Frequências absolutas e porcentagem referente aos motivos da Instauração da TCE na $1^{\circ}$ amostra. 
Tabela 16. Frequências absolutas e porcentagem referente aos motivos da Instauração da TCE na $2^{\circ}$ amostra

Tabela 17. Frequência absoluta e porcentagem em relação a instauração pelo TCU, débito solidário, convênio, processo em sigilo na $1^{\circ}$ e $2^{\circ}$ amostra. .84

Tabela 18. Frequência absoluta e porcentagem do cargo ou função do responsável das TCE na $1^{\circ}$ e $2^{\circ}$ amostra. .85

Tabela 19. Frequência absoluta e porcentagem das TCE por unidade federativa na $1^{\circ}$ e $2^{\circ}$ amostra .86

Tabela 20. Análises estatísticas na $1^{\circ}$ e $2^{\circ}$ amostra referente a duração do processo no TCU, quantidade de recursos e quantidade de pessoas em débito solidário.

Tabela 21. Médias, desvio padrão, variância das porcentagens das multas art. 57 e 58 da $1^{\circ}$ e $2^{\circ}$ amostra.

Tabela 22. Motivo de instauração do processo, frequências absolutas e porcentagens das multas dos artigos 57 e 58 na $1^{\circ}$ amostra. 89

Tabela 23. Motivo de instauração do processo, frequências absolutas e porcentagens das multas dos art. 57 e 58 na $2^{\circ}$ amostra. .91

Tabela 24. Motivo de instauração do processo que receberam multas de art. 57 e 58 na $1^{\circ}$ e $2^{\circ}$ amostra.

Tabela 25. Frequência absoluta e porcentagem em relação a instauração pelo TCU, débito solidário, convênio, processo em sigilo em relação a sanção de inabilitação para exercício de cargo em comissão ou função de confiança no âmbito da Administração Pública na Amostra 1 e 2 . .93

Tabela 26. Frequência absoluta e porcentagem dos cargos dos responsáveis na TCE em relação a sanção de inabilitação para exercício de cargo em comissão ou função de confiança no âmbito da Administração Pública na Amostra 1 e 2. .94

Tabela 27. Frequência absoluta e porcentagem aos motivos de instauração das TCE em relação a sanção de inabilitação para exercício de cargo em comissão ou função de confiança no âmbito da Administração Pública na Amostra 1 e 2 . .95

Tabela 28. Regressão linear da variável dependente multa do art. 57 na amostra 1 e 2 . .97 
Tabela 29. Regressão linear da variável dependente multa do art. 57 relacionado com as

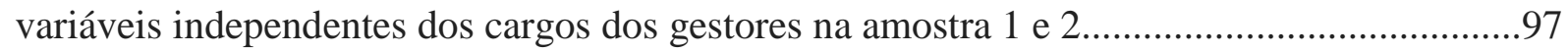

Tabela 30 Regressão linear da multa do art. 57 relacionado com o motivo da instauração na amostra 1 .

Tabela 31. Regressão linear da multa do art. 57 relacionado com o motivo da instauração na amostra 2

Tabela 32. Regressão linear da variável dependente porcentagem da multa do art. 57 na amostra 1 e 2 . 102

Tabela 33. Regressão linear da variável dependente porcentagem da multa do art. 57 relacionado com as variáveis independentes dos cargos dos gestores na amostra 1 e 2 ................. 102 Tabela 34. Regressão linear da porcentagem da multa do art. 57 relacionado com o motivo da instauração na amostra 1 104

Tabela 35. Regressão linear da porcentagem da multa do art. 57 relacionado com o motivo da instauração na amostra 2 105 


\section{Lista de Figuras}

Figura 1. Parte da rede jurídica envolvida na tomada de contas especial.................................37

Figura 2. Parte da rede jurídica envolvendo gestor de recurso público, autoridade administrativa

e Controladoria Geral da União.

Figura 3. Parte da rede jurídica envolvendo Controladoria Geral da União, Tribunal de Contas da União, Tribunal Superior Eleitoral e Ministério Público. 55 


\section{Resumo}

Quando ocorre irregularidades na prestação de contas dos gestores de recursos públicos, pode ser instaurada a tomada de contas especial (TCE), com o intuito de elucidar os fatos, identificar os responsáveis pelas irregularidades e quantificar o dano ao erário. Nesses casos, o Tribunal de Contas da União (TCU) é o responsável por julgar e aplicar as sanções previstas na lei. No Estudo 1, foi aplicado um modelo analítico-comportamental para identificar as contingências jurídicas descritas na leis e nos regulamentos relacionados com a tomada de contas especial. Além disso, foram descritas as sanções e a rede jurídica responsável pela sua aplicação. Essa rede inclui instituições de controle interno e externo, como as autoridades governamentais (por exemplo, os ministros), o Tribunal de Contas da União, dentre outros. O Estudo 2 investigou alguns aspectos das contingências vigentes que têm prevalecido em decisões do Tribunal de Contas da União, como o valor médio das multas aplicadas, a magnitude das sanções em função do valor do débito, o tipo de conduta e a sanção de inabilitação para o exercício de função pública. Essas análises foram baseadas em informações obtidas a partir de uma lista pública que o Tribunal de Contas da União envia ao Tribunal Superior Eleitoral (TSE) antes de cada eleição, que inclui os nomes de todos os indivíduos que tiveram suas contas públicas julgadas como irregulares pelo TCU nos últimos oito anos. Dependendo da decisão do Tribunal Superior Eleitoral, o gestor pode se tornar inelegível para se canditatar a cargos eletivos. Na lista analisada de 2014 havia 10.512 nomes. Foram seleccionadas duas amostras aleatórias de 371 nomes para a análise, para cada nome na lista, havia links para os processos judiciais, os acórdãos têm informações relativas a multas, condutas, quantidade de recursos, valores do débito entre outras. Os resultados indicaram que o valor absoluto das multas aplicadas são diretamente proporcionais ao valor do prejuízo causados aos cofres públicos. Já a porcentagem das multas aplicadas são inversamente proporcionais ao valor do débito, além disso, os maiores valores das multas são aplicadas para a conduta considerada mais graves (por exemplo, desfalque ou desvio). Os resultados do presente trabalho ilustram o potencial de investigações empíricas do Direito, com base em uma análise comportamental. A Análise Comportamental do Direito é uma ferramenta eficaz para identificar as contingências previstas e vigentes sobre o comportamento de destinatários da lei.

Palavras chave: Análise Comportamental do Direito, Tomada de Contas Especial, Contingências Jurídicas, Regimento Interno TCU, Lei nº 8.443/92 de julho de 1992. 


\begin{abstract}
When there are irregularities in the accounts rendered by public officials who manage federal resources, a special provision of accounts (Tomada de Contas Especial) is generated with the purpose of elucidating the facts, identifying those responsible for the irregularities and quantifying the produced damage. In such cases, the Federal Court of Accounts (Tribunal de Contas da União- TCU) is responsible for judging the process and applying any due sanctions. Study 1 applied a behavior-analytic model to identify the juridical contingencies of reinforcement planned by laws and regulations related to such special provision of accounts, such as the sanctions that are planned for each type of conduct, and the juridical network responsible for applying such sanctions, which includes internal control institutions, governmental authorities (e.g., Ministers), the Federal Court of Accounts, among others. Study 2 investigated some aspects of the actual reinforcement contingencies that have prevailed in rulings of the Federal Court, such as the average value of applied fines, and the magnitude of sanctions as a function of the amount of caused damaged, the type of misconduct and the job position held by public officials. These analyses were based upon information obtained from a public list that the Federal Court of Accounts sends to the Superior Electoral Court, before each election, which includes the names of all individuals that had their public accounts judged as irregular by TCU in the previous eight years. Depending upon a posterior decision of the Superior Electoral Court, officials that have their accounts not approved may become ineligible to be a candidate for elected positions. The list that was used contained the names of 10,512 individuals who had their accounts rendering rejected, from which two random samples of 371 names were selected for analysis. For each name on the list, there were links to the actual legal processes, from which information concerning fines, conducts, and such like, were collected. Results indicated that the absolute value of applied fines were directly proportional to the amount of damage caused to public resources, that the percentage of applied fines were inversely related to the amount of damage, and that applied fines were higher for more serious conducts (e.g., embezzlement). Taken together, results demonstrate the usefulness of the behavioral analysis of law to identify and analyze planned and actual legal reinforcement contingencies.
\end{abstract}

Keywords: Behavioral Analysis of Law, special provision of accounts, juridical contingencies, empirical legal study. 
A interação entre o Direito e outras ciências tem crescido muito nos últimos anos, por exemplo, Direito e Antropologia (e.g., Lima \&Varella, 2008 e Lima, 2008), Direito e Sociologia (e.g., Machado-Neto, 1987 e Scuro-Neto, 2009) e o próprio campo da Jurimetria, relação entre Direito e Estatística (e.g., Nunes, 2012; Zabala \& Silveira, 2014 e Loevinger, 1949). Outra interação crescente acontece entre o Direito e a Psicologia. Aguiar e Chinelato (2014) afirmam que: "a interpretação jurídica é mais uma forma de comportamento e, por isso, também pode ser analisada à luz da filosofia behaviorista de Skinner, cuja ideia fundamental é a de que 'os maiores problemas enfrentados hoje pelo mundo só poderão ser resolvidos se melhorarmos nossa compreensão sobre o comportamento humano"” (cf. Skinner, 1953/2006, p. 11).

Para compreender melhor os comportamentos individuais, a abordagem analíticocomportamental tem estudado o arranjo das contingências de reforço e punição (e.g., Moreira \& Medeiros, 2007; Skinner, 1981/2007; Todorov 1987). Contingência é um instrumento conceitual utilizado na análise de interações organismo-ambiente (cf. Skinner, 1953/2006). De acordo com Catania (1999), essas são “expressas como relações de probabilidade entre as respostas e suas consequências". Assim, as contingências descrevem a relação causal do comportamento, descrita em uma relação de dependência entre o contexto, o que o indivíduo faz e a probabilidade da ocorrência de determinadas consequências para aquelas ações. Planejar e implementar contingências que controlem os comportamentos pode promover o alcance de metas sociais.

O presente trabalho investigou como as contingências estão descritas em termos de leis e normas jurídicas referente à prestação de contas do gestor de recursos públicos. Pois, para os analistas do comportamento, uma das maneiras de compreender as normas e leis jurídicas é como contingências previstas com o intuito de controlar comportamentos (e.g., Aguiar, 2014; Baum, 2005; Moore, 2008). O objetivo das leis e normas relacionadas à prestação de contas é 
coibir a má gestão dos recursos públicos, reduzindo assim, o risco de desvios dos recursos, conforme previsto na Constituição Federal de 1988 (CF/88), no caput de seu art. 70, que estabelece:

A fiscalização contábil, financeira, orçamentária, operacional e patrimonial da União e das entidades da administração direta e indireta, quanto à legalidade, legitimidade, economicidade, aplicação das subvenções e renúncia de receitas, será exercida pelo Congresso Nacional, mediante controle externo, e pelo sistema de controle interno de cada Poder. (CF/88 art. 70)

A gestão dos recursos públicos federais é fiscalizada pelo sistema de controle interno (realizado pelos próprios órgãos e entidades dos entes federativos) e pelo controle externo (realizado pelo Poder Legislativo que é auxiliado pelas Cortes de Contas). A princípio, a fiscalização tem por objetivo reduzir riscos de má gestão, punindo atos irregulares e reavendo o ressarcimento de eventual dano ou prejuízo que tenha ocorrido (cf. Araújo, 2004). Para evitar eventual punição, cabe aos gestores a prestação de contas dos recursos utilizados. Uma vez identificada alguma irregularidade (dano ao erário, desfalque ou desvio, prática de ato ilegal ou ilegítimo, omissão no dever de prestar contas e aplicação irregular de recursos), o ordenamento jurídico brasileiro prevê que deverá ser instaurado um procedimento denominado tomada de contas especial (TCE).

A compreensão do universo jurídico como uma esfera das relações sociais é antiga, tendo em vista que o Direito tem uma função reguladora de comportamento social (cf. Lima, 1983). A pesquisa empírica no Direito é relativamente recente, porém de suma importância (e.g., Horta, Almeida \& Chilvarquer, 2014; Korobkin, 2015; Silva, 2016), sendo possível, por exemplo, mensurar o impacto de uma lei na sociedade e verificar se de fato ela funcionou como previsto. Nessa perspectiva, o presente estudo adentra na interação entre Direito e Psicologia, 
na aplicação da Análise Comportamental do Direito, no exame das contingências relacionadas a tomada de contas especial e a prestação de contas, com foco no comportamento de gestores públicos.

Na primeira seção, serão apresentados os conceitos teóricos utilizados pela Análise do Comportamento e Análise Comportamental do Direito. Na segunda seção, será discutido o processo de tomada de contas especial. Para tanto, foram realizados dois estudos: no Estudo 1 foi aplicado o modelo da Análise Comportamental do Direito para analisar as leis e normas jurídicas referentes à tomada de contas especial e, no Estudo 2, foram identificadas e descritas as contingências observadas nas TCE, ou seja, foram analisadas as contingências vigentes, ${ }^{1}$ referente aos atos do gestor de recursos públicos.

\section{Análise Comportamental do Direito}

A Análise do Comportamento busca compreender o comportamento humano enquanto produto da interação do organismo com seu meio (e.g., Skinner, 1953/2006; Baum, 2005; Moore, 2008). Para Skinner (1981/2007), o comportamento humano é selecionado por suas consequências em três níveis: filogenético (história da espécie), ontogenético (história do indivíduo) e cultural (aprendidos no grupo social e passados para os indivíduos através do comportamento verbal e não verbal). A análise do comportamento busca padrões comportamentais na relação funcional com o contexto no qual ocorrem, suas respectivas consequências, podendo essas serem reforçadoras ou punitivas (e.g., Skinner, 1953/2006; Baum, 2005; Schneider, 2012).

\footnotetext{
${ }^{1}$ Normalmente os Juristas utilizam o termo vigência para sinalizar que a lei está vigorando. O uso do termo vigente para qualificar contingências indica que as relações de dependência entre eventos ambientais e comportamentais estão de fato ocorrendo. Fazendo um paralelo ao Direito, o termo vigência está sendo usado no sentido que normalmente os juristas usam de eficácia da norma.
} 
Afirmar que o comportamento é selecionado por suas consequências significa dizer que, quando um comportamento é emitido, as consequências produzidas irão influenciar no padrão de ocorrência futura desse comportamento, ou seja, as consequências podem aumentar/manter ou diminuir a probabilidade de que determinado comportamento ocorra (cf. Moreira \& Medeiros, 2007). Matos (1999) afirma que os indivíduos seriam dotados de uma propensão inata de terem seus comportamentos alterados em decorrência dos efeitos de suas consequências. Por exemplo, uma criança ao tomar um choque por enfiar o dedo na tomada pode evitar fazê-lo novamente devido as consequências vivenciadas (choque). Se assim ocorrer, podemos dizer que tal comportamento foi punido pelas suas consequências, ou seja, as consequências do comportamento de colocar o dedo na tomada alteraram a probabilidade de uma nova ocorrência desse comportamento. Nesse exemplo, poderíamos dizer que a mudança no padrão comportamental foi causada pelas consequências (choque). Para Skinner (1953/2006), essa explicação causal é a seleção pelas consequências (e.g., Baum, 2005; Moore, 2008).

Ao afirmar que o comportamento foi selecionado por consequências, Skinner (1953/2006) refere-se então ao conceito de contingências. Nesse entendimento, a contingência pode ser descrita na seguinte relação: EM UM DADO CONTEXTO (estímulos discriminativos que antecedem um dado comportamento), SE (determinado comportamento ocorrer), ENTÃO (determinadas consequências serão apresentadas, com uma dada probabilidade) (e.g., Skinner, 1953/2006; Moreira \& Medeiros, 2007; Baum, 2005; Moore 2008).

Quando um comportamento é reforçado diante de um estímulo antecedente e não diante de outro, o estímulo passa a sinalizar a disponibilidade de reforço dado a uma determinada resposta (cf. Sério et. al., 2002). Quando um estímulo antecedente sinaliza reforço, este é chamado de estímulo discriminativo; esta relação é estabelecida na contingência, ou seja, na 
relação entre estímulos antecedentes, respostas e suas consequências. O estímulo discriminativo que antecedeu o comportamento reforçado passa a sinalizar a probabilidade da disponibilidade de reforço àquele comportamento (alterando assim a probabilidade que uma determina resposta ocorrer diante daquele estímulo); ao passo que os outros estímulos passam a sinalizar a não ocorrência de reforço dada tal comportamento (cf. Debert, Matos, \& Andery, 2006). Por exemplo, o motorista embriagado, ao visualizar uma fiscalização policial, poderia mudar o trajeto que estava fazendo a fim de evitá-la. Poderia-se dizer que o estímulo discriminativo (presença da polícia) sinalizou o comportamento (desviar da blitz) que deveria ser emitido a fim de obter reforço (evitar a multa).

Um tipo de estímulo discriminativo particularmente relevante para este trabalho são as regras (e.g., Baum, 1995; Glenn, 1987; 1988; Flores, 2004). Essas são comportamentos verbais que descrevem relações de contingências. De acordo com Matos (2001), "as regras são estímulos discriminativos de um tipo especial: elas envolvem o comportamento verbal de uma pessoa" (p. 51). Quando o motorista visualiza uma placa de trânsito escrita: "Tráfego interrompido, utilize o desvio", o comportamento do condutor se altera, indo por um trajeto alternativo, evitando assim o caminho com problema de tráfego. Nesse exemplo, podemos dizer que o comportamento foi influenciado pela regra.

Outros exemplos de regras são ordens, conselhos, leis jurídicas ou cientificas (cf. Skinner, 1953/2006, 1976). Vale ressaltar que as alterações nos padrões comportamentais que são acarretados por regras “estão submetidas às mesmas variáveis que controlam o comportamento dos indivíduos por meio do processo de seleção ontogenética” (cf. Aguiar, 2014, p. 257). Em suma, o comportamento de seguir ou não as regras passa pela história ontogenética do indivíduo. As regras são seguidas porque esse comportamento foi reforçado no passado (cf. Skinner, 1969). Além disso, como a regra descreve uma contingência (contexto - 
comportamento - consequência), quando o indivíduo entra em contato com as consequências previstas na regra, isso fortalece a relação do seguir regras. Scott (1971) aponta que existem sistemas sociais que modelariam o próprio comportamento de seguir regras, sendo isso uma característica presente em diferentes culturas.

Seguir regras possibilitou, na história humana que contingências remotas, que foram e são vitais para a sobrevivência dos indivíduos do grupo se tornassem relevantes para o comportamento dos indivíduos, ainda que não fizessem parte da história comportamental individual, mas sim do grupo (e.g., Aguiar, 2006; Watson, 1993). Aprender a seguir regras é um processo de aprendizagem individual, por exemplo, a criança é ensinada a seguir comandos dos seus pais ou cuidadores (cf. Hayes, Gifford \& Hayes, 1998). Quando as regras são congruentes com as condições ambientais físicas e sociais (contingências de seleção presentes), essas podem selecionar o seguir as regras, ou seja, tornar o comportamento de seguir regras bem estabelecido no repertório desses indivíduos (e.g., Hayes, Barnes-Holmes \& Roche, 2000; Aguiar, 2006).

Entretanto, em algumas situações pode acontecer da regra que descrevia uma determinada contingência não estar vigentes, ou seja, a regra descreve uma relação, mas na prática outra acontece. Por exemplo, a mãe fala com o filho: "só vai comer a sobremesa, se comer todo o almoço" (DADO O CONTEXTO [almoço], SE [almoçar tudo], ENTÃO [ganha sobremesa]). Porém, a criança não come tudo e mesmo assim a mãe dá a sobremesa. Nesse caso, não existe correspondência entre o que a regra previa e o que de fato ocorreu. Quando isso acontece é possível dizer que o comportamento será controlado pela contingência vigente e não pela prevista ou descrita na regra (cf. Catania, 1999).

Como dito anteriormente, as regras se fazem presentes em diversos contextos e um deles é no Direito. As leis poderiam ser compreendidas como regras, uma vez que descrevem relações 
entre comportamentos (por exemplo, infrações) e consequências (por exemplo, sanções). A Análise Comportamental do Direito propõe compreender os preceitos normativos constituições, leis, decretos, precedentes judiciais - estudados pelos juristas tradicionais, como contingências jurídicas (cf. Aguiar, 2013). Para tanto, seria possível compreender as normas jurídicas como uma parte de uma estrutura maior, que inclui um componente político-valorativo (a meta social) e um científico-descritivo (as premissas comportamentais), bem como os comportamentos e sanções previstas na lei. Por exemplo, o art. 306 da Lei $\mathrm{n}^{\circ} 9.503$ de setembro de 1997 (Anexo I), refere-se à condução de veículo automotor sob o efeito de álcool ou outras substâncias de efeitos análogos.

A estrutura da norma jurídica poderia ser descrita como uma contingência, por exemplo: \{DADO QUE [(Premissa Comportamental) Comportamentos seguidos por punição tendem a ter diminuída a probabilidade de sua ocorrência] DADO O CONTEXTO [Via pública], SE [Conduzir veículo automotor estando com concentração de álcool por litro de sangue igual ou superior a 6 (seis) decigramas, ou sob a influência de qualquer outra substância psicoativa que determine dependência ou Conduzir veículo automotor com capacidade psicomotora alterada em razão da influência de álcool ou de outra substância psicoativa que determine dependência], ENTÃO [detenção, de seis meses a três anos, multa e suspensão ou proibição de se obter a permissão ou a habilitação para dirigir veículo automotor] (Contingência Jurídica) [SE (contingência jurídica) ENTÃO (alcance da meta social)]\}.

Para Aguiar (2014), esse tipo de leitura jurídica é possível se levado em consideração o Direito positivo moderno, definido como mecanismo de controle social para o comportamento dos indivíduos, visto que os mesmos são submetidos a uma dada ordem social com poder de estabelecer normas de conduta de caráter coercitivo (e.g., Skinner, 1953; Luhmann, 1985; Kelsen, 1991). Para Aguiar (2014) isso significa que: 
O sistema social especializado do direito é concebido como composto essencialmente pelas organizações jurídicas estatais (os tribunais de todas as instâncias) e seu público alvo, ou seja, todos os indivíduos submetidos à jurisdição brasileira, nos termos da Constituição Federal e das leis infraconstitucionais (p. 264).

Nessa perspectiva, as sanções jurídicas visam de certa forma suprimir determinados comportamentos, omissivos ou comissivos, considerados indesejáveis, podendo, assim, ser denominadas de punições impostas pelo sistema jurídico (e.g., Aguiar, 2014; Kelsen, 1991; Luhmann, 1985). As contingências punitivas são impostas pela sociedade de maneira consistente, com o objetivo de suprimir ou punir os comportamentos socialmente indesejáveis que têm algum efeito danoso para o grupo. Assim, estaria justificada a necessidade dos grupos sociais de imporem tais contingências punitivas visando diminuir a frequência de tais comportamentos entre seus membros (cf. Aguiar, 2014). Historicamente, as organizações estatais se mostraram as agências mais adequadas ao cumprimento de tal função (e.g., Skinner, 1953; Weber, 1968; Luhmann, 1985). Nesse sentido, Aguiar (2013) conclui que "as contingências punitivas impostas por meio de organizações jurídicas deveriam ser chamadas de contingências jurídicas” (p. 182).

O mesmo autor destaca ainda que a lei pela imposição da sanção, seja ela punitiva ou reforçadora (normalmente punitiva), objetiva o controle da conduta descrita pela norma. Para tanto, a maioria das sanções envolvem a imposição de penas, específicas para cada infração/crime, as quais supostamente seriam eficazes no intuito de reduzir a frequência do comportamento indesejado na sociedade (cf. Aguiar, 2014). Além disso, na ausência da imposição da sanção, o comportamento indesejável seria frequente e em certa magnitude poderia vir a comprometer o bem-estar da comunidade. Por exemplo, no caso do dano ao erário, 
a premissa em questão pressupõe que a conduta 'desvio de dinheiro', na ausência da sanção, seria frequente e em tal magnitude que prejudicaria o bem-estar da sociedade, tendo em vista que o dinheiro destinado a determinado fim social não seria efetivado.

Para tanto, Aguiar (2014) conclui que:

As normas jurídicas são concebidas como uma regra mais abrangente na qual o comportamento de impor a contingência jurídica - ou seja, imputar uma sanção a uma determinada conduta omissiva ou comissiva descrita na lei - é causalmente vinculado à obtenção de um estado de coisas definido politicamente pela sociedade como desejável, ou seja, a meta social (pp. 265-266).

Em uma relação SE-ENTÃO é estabelecida a premissa comportamental, SE a punição diminui a probabilidade de ocorrer futuramente um determinado comportamento ENTÃO uma meta social pode ser alcançada, para que isso ocorra é introduzida a contingência jurídica. Depois que essa relação é estabelecida, vem o segundo SE-ENTÃO, o qual estabelece a contingência jurídica propriamente dita (e.g., Aguiar, 2006; Aguiar, 2013; Aguiar, 2014). As normas jurídicas poderiam ser compreendidas como sendo uma regra, que descreve premissa comportamental, as contingência jurídica, podendo descrever toda a relação (contexto comportamento - consequência) ou mesmo parte dessa contingência, por exemplo, comportamento e consequência e ainda a meta social, podendo estar subentendida na norma.

A meta social estará contida nas contingências jurídicas, por exemplo, SE [Conduzir veículo automotor estando com concentração de álcool por litro de sangue igual ou superior a 6 (seis) decigramas, ou sob a influência de qualquer outra substância psicoativa que determine dependência ou Conduzir veículo automotor com capacidade psicomotora alterada em razão da influência de álcool ou de outra substância psicoativa que determine dependência], descreve o comportamento indesejável socialmente que deverá sofrer sanções jurídicas. Se tal 
comportamento ocorrer, ENTÃO [detenção, de seis meses a três anos, multa e suspensão ou proibição de se obter a permissão ou a habilitação para dirigir veículo automotor]. A contingência punitiva relaciona-se ao alcance da meta social, qual seja a diminuição de acidentes de trânsitos, acarretando menor demanda de pacientes a serem atendidos no sistema público de saúde. Ou seja, a lei, nesse caso, envolve o alcance de uma meta social, embora de forma não explicitada.

Nessa perspectiva, pode se dizer, com base na análise do comportamento, que as normas jurídicas, além das contingências jurídicas, são contingências selecionadoras de comportamentos. De acordo com Aguiar (2014), a meta social relaciona-se com o estado de coisas considerado como socialmente desejável, cujo alcance depende da alteração comportamental - diminuição ou aumento da frequência do comportamento referido na contingência jurídica - visado pela instituição da contingência jurídica. Sendo assim, Aguiar (2013) afirma que:

Na visão do behaviorismo radical, a norma jurídica tradicional - por exemplo, o art. 155 do Código Penal Brasileiro - é uma contingência comportamental, isto é, uma ligação contingente entre um comportamento (a conduta comissiva ou omissiva descrita na norma) e uma consequência (a sanção). Na sua grande maioria, tais contingências são punitivas, isto é, visam a tornar a conduta sancionada menos frequente. Podendo, porém, ser também reforçadoras, no sentido de visar a tornar a conduta sancionada mais frequente, como nos casos da chamada delação premiada e de programas de incentivo à requisição da nota fiscal pelo consumidor no ato da compra. Eu chamo tais contingências comportamentais de contingências jurídicas (p. 268). 
Tradicionalmente, a análise do comportamento vem estudando leis enquanto um fenômeno envolvendo metacontingências (e.g., Todorov et al., 2004; Pereira, 2005; Prudêncio, 2005; Todorov, 2005). Martins (2009) afirma que uma lei é mais do que comportamento verbal, pois seu conteúdo não se restringe apenas à descrição de regras de conduta social, mas também à codificação de procedimentos controladores de agências governamentais. Já Todorov (2005) destaca a complexidade do controle do comportamento previsto nas normas jurídicas, pois os textos legais não se resumem às respostas em seus artigos constituintes, mas especificam circunstâncias de aplicação e, às vezes, apontam condições atenuantes. O autor afirma ainda que:

De um ponto de vista comportamental, leis são constituídas de contingências tríplices de reforço entrelaçadas em metacontingências. Então, é uma forma de olhar como uma lei controla o comportamento é começar com a análise da lei como uma declaração escrita de contingências entrelaçadas que controlam o comportamento individual (Todorov, 2005, p.87).

A proposta do presente trabalho é realizar uma análise baseada na Análise Comportamental do Direito, não como metacontingência, mas sim, compreendendo o direito enquanto fenômeno social, e fornecendo, então, uma ferramenta analítica aplicada ao direito. Aguiar (2014) afirma que essa ferramenta possibilitaria "ao jurista, em especial ao aplicador do direito, analisar os fins sociais das normas e as premissas comportamentais que governam a obtenção ou não de tais fins, mediante a imputação de sanções a determinados comportamentos humanos" (p.269). Em suma, a Análise Comportamental do Direito pode ser vista como uma ferramenta capaz de fazer do direito uma ciência do comportamento humano aplicada. Para Aguiar (2006) “o direito como uma ciência humana ou social aplicada não é novidade no Brasil, 
porém, nunca chegou a haver um embasamento teórico-metodológico duradouro, capaz de tornar realidade essa ideia" (p.9).

\section{Tomada de Contas Especial (TCE)}

A tomada de contas especial tem por objetivo a fiscalização e o julgamento da conduta do gestor na administração do recurso da União Federal quando há indícios de irregularidades, buscando o ressarcimento de possíveis prejuízos gerados aos cofres públicos. Portanto, o objetivo é identificar responsáveis e quantificar o prejuízo aos cofres públicos, para reaver esse dinheiro. De acordo com o regimento da Controladoria Geral da União (CGU, 2013), “a TCE tem como base a conduta do agente público que agiu em descumprimento à lei ou daquele que, agindo em nome de um ente público, deixou de atender ao interesse público” (p.9).

A má conduta do gestor pode se dar pela omissão no dever de prestar contas, pelas irregularidades na gestão do recurso público causando o dano ao erário, pela não execução ou execução parcial do objeto para o qual o dinheiro foi destinado. Pode ainda ser causada pelo desvio de finalidade para a qual o recurso foi destinado, ocorrência de desfalque, desvio ou desaparecimento do dinheiro, bens ou valores públicos, dentre outras irregularidades.

A definição de TCE está contida nos seguintes normativos:

Decreto - Lei n. ${ }^{\circ}$ 200, de 25.2.1967:

Art. 84. Quando se verificar que determinada conta não foi prestada, ou que ocorreu desfalque, desvio de bens ou outra irregularidade de que resulte prejuízo para a Fazenda Pública, as autoridades administrativas, sob pena de co-responsabilidade e sem embargo dos procedimentos disciplinares, deverão tomar imediatas providências para assegurar o respectivo ressarcimento e instaurar a tomada de contas, fazendo-se as comunicações a respeito ao Tribunal de Contas.

Lei $\mathrm{n}^{\circ}$ 8.443/92, de 16.07.1992:

Art. $8^{\circ}$ Diante da omissão no dever de prestar contas, da não comprovação da aplicação dos recursos repassados pela União, na forma prevista no inciso VII do art. $5^{\circ}$ desta lei, da ocorrência de desfalque ou desvio de dinheiros, bens ou valores públicos, ou, ainda, da prática de qualquer ato ilegal, ilegítimo ou antieconômico de que resulte dano ao erário, a autoridade administrativa competente, sob pena de responsabilidade solidária, deverá 
imediatamente adotar providências com vistas à instauração da tomada de contas especial para apuração dos fatos, identificação dos responsáveis e quantificação do dano.

Regimento Interno do TCU, de 02.01.2012:

Art. 197. Diante da omissão no dever de prestar contas, da não comprovação da aplicação dos recursos repassados pela União na forma prevista no inciso VIII do art. $5^{\circ}$, da ocorrência de desfalque ou desvio de dinheiros, bens ou valores públicos, ou, ainda, da prática de qualquer ato ilegal, ilegítimo ou antieconômico de que resulte dano ao erário, a autoridade administrativa competente, sob pena de responsabilidade solidária, deverá imediatamente adotar providências com vistas à instauração de tomada de contas especial para apuração dos fatos, identificação dos responsáveis e quantificação do dano.

Instrução Normativa TCU n ${ }^{\circ} 71 / 2012$, de 28.11.2012:

Art. $2^{\circ}$ Tomada de contas especial é um processo administrativo devidamente formalizado, com perguntas e respostas, para apurar responsabilidade por ocorrência de dano à administração pública federal, com apuração de fatos, quantificação do dano, identificação dos responsáveis e obter o respectivo ressarcimento. Parágrafo único. Consideram-se responsáveis pessoas físicas ou jurídicas às quais possa ser imputada a obrigação de ressarcir o Erário.

Portaria Interministerial MPOG/MF/CGU n ${ }^{\circ}$ 507, de 24.11.2011:

Art. 82. A Tomada de Contas Especial é um processo devidamente formalizado, dotado de rito próprio, que objetiva apurar os fatos, identificar os responsáveis e quantificar o dano causado ao erário, visando ao seu imediato ressarcimento.

A TCE é instaurada com o intuito de verificar se, de fato, ocorreu dano ao erário . Para tanto, faz-se necessária uma investigação a fim de analisar as informações referentes a esse dano. Consequentemente são apurados: os fatos detalhados, a ocorrência do prejuízo, a identificação dos responsáveis e assim, adotadas medidas cabíveis para que ocorra o ressarcimento. A Portaria Interministerial MPOG/MF/CGU n ${ }^{\circ}$ 507, de novembro de 2011, destacou nos seus art. $82, \S \S 1^{\circ}$ e $2^{\circ}$, uma série de possíveis situações, como inexecução total ou parcial dos contratos, desvio de finalidade na aplicação dos recursos destinados, dentre outras. Essas são situações nas quais poderiam ser instaurados os processos de tomada de contas especial, contida no inciso I do art. 72 (Anexo II).

Cabe destacar que, no caso das TCE, não existe prescrição para essas irregularidades. Contudo, quando houver passado o prazo superior a 10 anos entre a irregularidade que gerou o 
prejuízo e a primeira notificação ao responsável, não é necessário se instaurar um processo de TCE. Nesse caso, deverá ser aberto um processo administrativo.

As TCE somente são instauradas depois que todas as medidas administrativas foram adotadas dentro do órgão ou entidade no qual ocorreu o dano. É necessário esgotar todas as possíveis medidas administrativas, e quando ainda assim, não tiver sido obtido ressarcimento, apesar de constatada a irregularidade, então se formaliza a instauração de um processo de TCE. A irregularidade em si não é suficiente para a instauração da TCE. É preciso que o órgão ou entidade demonstre que de fato ocorreu um dano aos cofres públicos como consequência dessa irregularidade.

Uma vez que todas as medidas possíveis foram esgotadas dentro do órgão ou entidade, a TCE deve ser instaurada imediatamente. Se isso não acontecer, o órgão ou entidade pode sofrer pena de corresponsabilidade em relação ao prejuízo apurado contra o erário. Somente podem ser instaurados processos com valor superior a $\mathrm{R} \$ 75$ mil, sendo que valores menores que esse devem ser recuperados através de medidas administrativas do próprio órgão ou entidade onde ocorreu a irregularidade (art. XX, IN TCU 71/2012). Todavia, se o responsável pelas contas que geraram a irregularidade estiver envolvido em mais de um processo, os débitos devem ser consolidados em um único processo e assim, instaura-se a TCE. Quando a TCE é instaurada no órgão ou entidade, esta tem 45 dias para ser enviada ao Ministério da Transparência, Fiscalização e Controladoria-Geral da União ${ }^{2}$ e este tem até 180 dias para enviar o processo para o Tribunal de Contas da União (TCU), como pode ser observado na Tabela 1.

As TCE podem ainda serem instauradas diretamente pela CGU. O órgão (CGU) realiza sorteios públicos para fiscalizar o uso dos recursos públicos federais que são entregues a

\footnotetext{
${ }^{2}$ O Ministério da Transparência, Fiscalização e Controladoria-Geral da União é a antiga Controladoria Geral da União. Essa mudança ocorreu no Governo Temer com a publicação da Lei nº13.341 no Diário Oficial da União dia 30/09/16. Ao longo desse trabalho utilizou-se a sigla CGU para se referir a esse ministério.
} 
municípios e estados. Desde 2003, no âmbito do programa Fiscalização por Sorteio essa prática tem sido realizada.

Tabela 1

Exemplo do fluxograma da instauração de uma TCE

\begin{tabular}{ccc}
\hline TCE instaurada em & $\begin{array}{c}\text { Prazo para encaminhar a } \\
\text { TCE à CGU }\end{array}$ & $\begin{array}{c}\text { Prazo para encaminhar ao } \\
\text { TCU }\end{array}$ \\
\hline 01.05 .2013 & 15.06 .2013 & 31.06 .2014 \\
& (45 dias após a instauração da & $\begin{array}{c}\text { (180 dias findo o exercício } \\
\text { TCE). }\end{array}$ \\
& & financeiro em que foi instaurada a \\
& TCE). \\
\hline
\end{tabular}

De acordo com o site da CGU, “a cada sorteio são definidos 60 municípios, para exame de contas e documentos pelos auditores da CGU, além de inspeção pessoal e física das obras e serviços em realização". Podem ser feitos três sorteios anuais, assim podem ser fiscalizados até 180 municípios em um ano.

Uma vez que a TCE é encaminhada ao Tribunal de Contas da União (TCU), ficará a cargo do TCU o julgamento das TCE. A competência do Tribunal de Contas da União está estabelecida nos art. 70 e 71 da Constituição Federal, c/c o art. $1^{\circ}$ da Lei no .8 .443 , de 16.07.1992 (Anexo III) e Regimento Interno do TCU (Anexo IV). Cabe ao TCU, julgar as contas dos administradores e demais responsáveis por dinheiros, bens e valores públicos; proceder à fiscalização contábil, financeira, orçamentária, operacional e patrimonial dos órgãos e entidades da União (cf. Costa, 2006). As atribuições do TCU são de função fiscalizadora, opinativa, julgadora, sancionadora, corretiva, consultiva, informativa, ouvidora e normativa (cf. Fernandes, 2008).

As fiscalizações que ocorrem via sorteio público e o Portal da Transparência são igualmente importantes no controle das contas em estados e municípios. O TCU ao realizar auditorias e inspeções, por iniciativa própria ou de terceiros (decorrentes de solicitações do 
Congresso Nacional ou a partir da competência de ouvidoria), e ao apreciar relatórios de fiscalização, exerce as competências informativa e corretiva (cf. Teixeira, 2006). Ocorrendo dano ao erário, o TCU converte o processo de fiscalização em Tomada de contas especial.

Como nos processos judiciais e demais processos administrativos, os processos no TCU seguem etapas, como a admissibilidade, a instrução, o parecer do Ministério Público, o julgamento (ou apreciação, no caso de atos sujeitos ao registro e nas fiscalizações de atos e contratos) e, por fim, a fase dos recursos (cf. Lima, 2011). De acordo com o art. 144 do Regimento Interno do TCU, são partes no processo o responsável e o interessado. O Tribunal de Contas da União, em seu artigo $2^{\circ}$, define que:

O responsável é aquele que figure no processo em razão da utilização, arrecadação, guarda, gerenciamento ou administração de dinheiros, bens e valores públicos, ou pelos quais a União responda, ou que, em nome desta, assuma obrigações de natureza pecuniária, ou por ter dado causa a perda, extravio ou outra irregularidade de que resulte prejuízo ao erário (TCU, 2015).

A assistência das partes por advogado não é obrigatória no processo do TCU. No entanto, as partes não podem retirar autos das dependências do Tribunal sem que seja por meio de advogado legalmente constituído. Outro fator importante nesse processo é que o denunciante não é necessariamente interessado no processo.

A decisão definitiva do TCU é expressa via acórdão, que é publicado no Diário Oficial da União. A partir daí, o responsável é notificado para que recolha no prazo estabelecido no Regimento Interno do TCU, os valores da dívida atualizada monetariamente, acrescida de juros, bem como as multas impostas pela Corte (cf. Fernandes, 2008). No caso do pagamento não ser efetuado dentro do prazo estipulado, o "TCU pode determinar, em caso de servidores públicos, o desconto integral ou parcelado da dívida nos vencimentos, salários ou proventos do 
responsável, ou ainda, autorizar que o Ministério Público junto ao TCU cobre judicialmente a dívida" (cf. Gregório, 2012, p.41).

As prestações e tomadas de contas podem ser julgadas como regulares (art. 207):

Art. 207. As contas serão julgadas regulares quando expressarem, de forma clara e objetiva, a exatidão dos demonstrativos contábeis, a legalidade, a legitimidade e a economicidade dos atos de gestão do responsável.

Parágrafo único. Quando julgar as contas regulares, o Tribunal dará quitação plena ao responsável.

Podem ser julgadas como regulares com ressalva:

Art. 208. As contas serão julgadas regulares com ressalva quando evidenciarem impropriedade ou qualquer outra falta de natureza formal de que não resulte dano ao erário. $\S 1^{\circ} \mathrm{O}$ acórdão de julgamento deverá indicar, resumidamente, os motivos que ensejam a ressalva das contas.

$\S 2^{\circ}$ Na hipótese prevista no caput, o Tribunal dará quitação ao responsável e lhe determinará, ou a quem lhe haja sucedido, se cabivel, a adoção de medidas necessárias à correção das impropriedades ou faltas identificadas, de modo a prevenir a ocorrência de outras semelhantes.

Outra possibilidade é que a tomada de contas seja julgada como irregular, de acordo com o art. 202 do Regimento Interno do TCU, o relator ou o Tribunal:

I- definirá a responsabilidade individual ou solidária pelo ato de gestão inquinado;

II - se houver débito, ordenará a citação do responsável para que, no prazo de quinze dias, apresente alegações de defesa ou recolha a quantia devida, ou ainda, a seu critério, adote ambas as providências;

III - se não houver débito, determinará a audiência do responsável para que, no prazo de quinze dias, apresente razões de justificativa;

IV-adotará outras medidas cabíveis. 
$\S 1^{\circ}$ Os débitos serão atualizados monetariamente e, caso o responsável venha a ser condenado pelo Tribunal, serão acrescidos de juros de mora, nos termos da legislação vigente, devendo-se registrar expressamente essas informações no expediente citatório.

$\S 2^{\circ} \mathrm{Na}$ oportunidade da resposta à citação, será examinada a ocorrência de boa-fé na conduta do responsável e a inexistência de outra irregularidade nas contas.

$\S 3^{\circ}$ Comprovados esses requisitos e subsistindo o débito, o Tribunal proferirá, mediante acórdão, deliberação de rejeição das alegações de defesa e dará ciência ao responsável para que, em novo e improrrogável prazo de quinze dias, recolha a importância devida.

$\S 4^{\circ} \mathrm{Na}$ hipótese do parágrafo anterior, a liquidação tempestiva do débito atualizado monetariamente saneará o processo e o Tribunal julgará as contas regulares com ressalva e dará quitação ao responsável.

$\S 5^{\circ} O$ ofício que der ciência ao responsável da rejeição das alegações de defesa deverá conter expressamente informação sobre o disposto no parágrafo anterior.

$\S 6^{\circ}$ Não reconhecida a boa-fé do responsável ou havendo outras irregularidades, o Tribunal proferirá, desde logo, o julgamento definitivo de mérito pela irregularidade das contas.

$\S 7^{\circ}$ No caso de rejeição das razões de justificativa, a comunicação a que se refere o $\S 3^{\circ}$ do art. 179 será efetivada na mesma oportunidade em que se fizer a notificação da aplicação das sanções previstas nos art.. 268 e 270.

$\S 8^{\circ}$ O responsável que não atender à citação ou à audiência será considerado revel pelo Tribunal, para todos os efeitos, dando-se prosseguimento ao processo.

O art. 202 complementa o art. 16 da lei 8.443 (Lei Orgânica), inciso III, alíneas "a", "b”, "c" e "d", que descrevem as quatro ocorrências cometidos pelos gestores que acarretam no julgamento das contas como irregulares:

Art. 16. As contas serão julgadas:

III - irregulares, quando comprovada qualquer das seguintes ocorrências:

a) omissão no dever de prestar contas; 
b) prática de ato de gestão ilegal, ilegítimo, antieconômico, ou infração à norma legal ou regulamentar de natureza contábil, financeira, orçamentária, operacional ou patrimonial;

c) dano ao erário decorrente de ato de gestão ilegítimo ao antieconômico;

d) desfalque ou desvio de dinheiros, bens ou valores públicos.

Os principais objetivos das instaurações das TCE são identificar os responsáveis pelo dano ao erário e buscar reaver o valor da causa em questão. O TCU, ao julgar as TCE, busca recuperar o que foi desviado do erário ou apropriado do patrimônio público. De acordo com Teixeira (2006), o índice de recuperação de débitos e multas aplicados pelo TCU tem ficado em torno de $1 \%$.

Compreender como a tomada de contas especial é instaurada, julgada e executada para que o erário recupere o dano envolve escrutinar a rede jurídica, pois o fenômeno jurídico é interativo por excelência. Aguiar (2006b) afirma que "entender o direito como um sistema de redes significa não mais admitir um entendimento vertical das relações jurídicas, mas um complexo de interações recíprocas, que se bifurcam, agindo e retroagindo, isto é, dinamicamente se auto constituindo" (p. 36).

\section{Objetivos}

Este trabalho tem como objetivo a identificação e a descrição das contingências previstas nas leis e a averiguação de contingências vigentes no comportamento dos Gestores de Recursos Públicos referente à tomada de contas especial.

Esta tese está dividida em dois estudos:

Estudo 1: identificar e descrever as principais contingências previstas (ou especificadas) na legislação e nos documentos oficiais que definem a tomada de contas especial (TCE), analisando-as com base na Análise Comportamental do Direito. 
Estudo 2: identificar e descrever alguns aspectos das contingências que, de fato, estão presentes na tomada de contas especial vigentes nos comportamentos dos gestores de recursos públicos. Para a realização do Estudo 2, foram identificadas e descritas as contingências observadas nas TCE. Foram selecionadas algumas variáveis relacionadas às dimensões ou aos aspectos das contingências vigentes. Procurou-se identificar quais variáveis são preditoras das sanções aplicadas pelo TCU, como os valores das multas aplicadas e a aplicação de inabilitação para ocupar cargo ou função pública. Tais variáveis foram consideradas variáveis dependentes. Como variáveis independentes, foram selecionados o montante do débito, montante do débito analisado, convênio, se houve recursos, cargos e motivos de instauração do processo.

\section{Estudo 1}

Quando alguém administra o patrimônio de outra pessoa, conflitos de interesse podem surgir, pois o que é bom para um não o é necessariamente para o outro. Por exemplo, enquanto que ao administrador do patrimônio pode interessar elevar maximamente sua própria remuneração, isso pode ser incongruente com o interesse do proprietário, que pode preferir pagar salários tão baixos quanto possível para maximizar seus lucros. Esse potencial desencontro de interesses ficou conhecido na literatura como "conflito de agência", o qual decorre, geralmente, do distanciamento entre o proprietário e o gestor do patrimônio (e.g., Eisenhardt, 1989; Peters, 2007). Para muitos autores, esse tipo de conflito está na origem da necessidade do trabalho de auditoria, o qual objetiva verificar, dentre outras coisas, se as contas prestadas pelo administrado ao proprietário são corretas e confiáveis, descrevendo fielmente a utilização dos recursos (e.g., Boynton et. al, 2002).

Quando os recursos são públicos, provenientes de tributos pagos por toda a sociedade, o conflito de agência pode ser ainda maior, tendo em vista que a propriedade dos recursos administrados se torna difusa, pertencendo a todos. Além disso, a relação entre os partícipes é 
complexa e indireta, pois o cidadão, que seria, em última instância, dono do dinheiro, não pode, por exemplo, demitir e substituir direta e rapidamente o administrador, como faria o dono de uma empresa. Medidas como essa devem ser tomadas com base em procedimentos complexos, regidos por leis, e baseados em ações de várias instituições, em vez de ações de indivíduos.

Devido ao potencial conflito de agência, envolvendo os interesses de gestores públicos e os interesses da sociedade, torna-se necessária a implementação de sistemas e mecanismos que atenuem os riscos de má gestão dos recursos, que podem gerar desvios, fraudes e outras irregularidades, causando danos ao erário e prejuízos à prestação de serviços à sociedade. No Brasil, esses danos podem ser significativos, como ilustra análise realizada pelo Instituto Nacional de Criminalística da Polícia Federal em 160 trabalhos urbanos em diferentes municípios nos anos 2006 e 2007, a qual constatou que a cada $\mathrm{R} \$ 3$ investidos em obras, $\mathrm{R} \$ 1$ teve desvio comprovado, o equivalente a $\mathrm{R} \$ 2,621$ bilhões somente nos anos de 2006 e 2007 (cf. Milani \& Deak, 2007).

No âmbito federal, com o propósito de reduzir o risco de desvios e má gestão dos recursos públicos, a Constituição Federal de 1988 (CF/88), o parágrafo único do art. 70 determina que: "prestará contas qualquer pessoa física ou jurídica, pública ou privada que utilize, arrecade, guarde, gerencie ou administre dinheiros, bens e valores públicos ou pelos quais a União responda, ou que, em nome desta, assuma obrigações de natureza pecuniária”.

Portanto, qualquer pessoa que, de qualquer forma, gerencie recursos públicos federais poderá ser fiscalizado pelo sistema de controle interno e de controle externo. Essa fiscalização tem o objetivo de reduzir riscos de má gestão, punindo atos irregulares e procurando o ressarcimento de eventual dano ou prejuízo que tenha ocorrido (cf. Araújo, 2004). Qualquer gestor de recurso federal deve, portanto, prestar contas dos recursos utilizados. Isso pode se dar de várias maneiras, embora tipicamente haja um processo de prestação de contas ordinária (e.g., 
rotineira), que, no caso dos órgãos da administração direta (e.g., ministérios) e indireta (e.g., autarquias, fundações, empresas estatais), por exemplo, tem periodicidade anual. No caso de recursos descentralizados como, por exemplo, para estados e municípios, esses devem prestar contas dos convênios ao órgão responsável pela descentralização dos recursos, geralmente um ministério supervisor. O ministério deve analisar as contas sobre as quais podem atuar também a CGU e o TCU.

No caso de haver indícios de irregularidades, primeiramente são realizadas medidas administrativas e investigativas para reparação do dano dentro dos órgãos e entidades federais (e.g., ministérios). Uma vez esgotadas as medidas administrativas e investigativas dentro do órgão que ocorreu o dano, pode ser instaurada a tomada de contas especial.

Portanto, a tomada de contas especial (TCE) objetiva julgar a gestão dos recursos públicos, recuperando valores mal geridos. Por exemplo, em 2012 foram instaurados 858 processos de TCE, com 1.576 mil responsáveis condenados e o valor das condenações chegou a R\$1,28 bilhão de reais (TCU, 2012, p. 29).

Os gestores de recursos públicos devem conhecer e cumprir as normas legais e regulamentares a partir do orçamento e das licitações, com orientação sobre empenhos, adiantamentos, administração de material, contabilidade, tomada de contas e controle interno (TCU, 2012). Pode-se dizer, que a má gestão do recurso público envolveria o descumprimento da lei, tendo em vista que o princípio da legalidade, insculpido no art. 37 da $\mathrm{CF} / 88$. Esse estabelece que o gestor público só pode fazer aquilo previsto em lei, diferentemente do cidadão comum, o qual pode fazer qualquer coisa que não seja proibido por lei.

Para Kelsen (1991) “o Direito, que constitui o objeto deste conhecimento, é uma ordem normativa da conduta humana, ou seja, um sistema de normas que regulam o comportamento humano" (p.15). Nessa perspectiva, as leis e as normas jurídicas envolvendo o uso e a prestação 
de contas dos recursos públicos, a priori, visam controlar o comportamento dos gestores que administram recursos federais. Por essa razão, as leis e normas jurídicas podem ser descritas em termos de relações entre certos comportamentos e determinadas consequências previstas.

Para Aguiar (2014) as leis estabelecidas pelo Direito teriam a função de influenciar padrões comportamentais. Para que isso ocorra, seria preciso identificar as normas jurídicas, ou seja, a conduta descrita na lei e a previsão de punição ou, mais raramente, reforço. Para Aguiar (2014) as normas jurídicas devem ser concebidas de maneira ampla, a lei escrita, por outro lado, poderia ser vista como basicamente um estímulo discriminativo, sendo sinalizações diferentes para o aplicador da lei (juiz), outros operadores (e.g., promotor, advogado) ou mesmo para o destinatário da lei, aquele a quem a lei procura atingir, nesse caso, o gestor de recursos públicos. As normas jurídicas, então, visariam ao alcance de metas sociais, ou seja, elas seriam um meio ('instrumento') de controle social do comportamento, por intermédio, basicamente, da punição de condutas consideradas socialmente indesejáveis.

O objetivo desse trabalho foi analisar e identificar as contingências descritas nas leis pertinentes que se aplicam aos gestores de recursos públicos. No Estudo 1 foi aplicado o modelo da Análise Comportamental do Direito na análise das leis e normas jurídicas referentes à tomada de contas especial, descritas em termos de contingências, nos termos propostos por Aguiar (2014).

\section{Método}

Na perspectiva da Análise Comportamental do Direito, é possível compreender as normas jurídicas como regras idealizadas pela rede de relações estabelecidas e que descrevem a contingência jurídica. A análise da contingência jurídica pode possibilitar o controle do comportamento socialmente indesejado, tendo em vista que sanções (consequências 
programadas para determinados comportamentos) podem funcionar como punição e proporcionar o alcance de metas sociais, devido às premissas comportamentais vigentes.

Foi descrita a rede de relações estabelecidas entre juristas, executores da lei e gestores dos recursos públicos na tomada de contas especial. Essa rede envolve, do ponto de vista organizacional, o Tribunal de Contas da União (fiscalização do recurso da União e julgamento das TCE), Ministério da Transparência, Fiscalização e Controladoria-Geral da União (fiscalização do recurso da União no Poder Executivo), ministérios (na fiscalização de recurso da União em convênios/contratos) e Ministério Público junto ao TCU. Em termos normativos, ou seja, das regras que governam as relações jurídicas entre as organizações citadas, destacamse o Decreto $n^{\circ} 8.109$, de setembro de 2013, o Decreto ${ }^{\circ} 6.170$, de julho de 2007, a Lei $n^{\circ}$ 8.443, de julho de 1992 (Lei Orgânica do Tribunal de Contas da União) e a Lei nº.429, de junho de 1992.

Baseado na análise descritiva das normas e contingências jurídicas, foram identificadas as contingências jurídicas presentes na legislação referente à tomada de contas especial. Foram analisadas as normas relacionadas à tomada de contas especial que regem a gestão de recursos públicos federais. Na análise desses documentos foram descritas as normas e as contingências jurídicas, bem como identificadas as metas sociais. Além disso, identificaram-se as contingências estabelecidas na Lei Orgânica do Tribunal de Contas (Lei 8443/92) e o Normativo Interno do TCU (aprovado pela resolução do TCU n ${ }^{\circ} 155 / 2002$ ). A lei foi analisada, considerando seus artigos, parágrafos e incisos de cada uma dessas normas, e considerando que seus conteúdos são complementares, descritos nos termos da contingência tríplice.

$\mathrm{Na}$ primeira análise dessas contingências, foram identificas quais seriam a normas jurídicas e quais seriam contingências jurídicas. Após sua identificação, as normas e contingências jurídicas foram destrinchadas. As normas jurídicas foram fragmentadas em 
premissas comportamentais, contingência jurídica e as metas sociais. As contingências jurídicas foram analisadas como contingências tríplice, sendo identificada os antecedentes da lei, os comportamentos e as sanções (consequências).

\section{Resultados}

A rede jurídica referente a tomada de contas especial foi descrita focando os principais órgãos envolvidos no processo das TCE. Essa rede de relações envolve juristas e operadores das leis, como pode ser visto na Figura 1 de forma resumida.

\section{Ministérios e outros órgãos do Poder Judiciário e Legislativo}

São responsáveis por acompanhar os prazos da prestação de contas, analisar as contas fornecida pela concedente, podendo aprovar, aprovar com ressalvas ou rejeitar as contas.

- Adotar medidas administrativas e investigativas para reparação do dano dentro dos órgãos e entidades federais.

- Instaurar a TCE;

- Enviar a TCE a CGU.

\section{Tribunal de Contas de União}

- Recebe as TCE advindas do CGU;

- Instaurar as TCE.

- Julga as TCE

- Envia lista com o nome dos condenados ao TSE

- Envia pedidos de cobrança ao MP.

- Quando o TCU identifica indícios de fraude ou de qualquer outro crime no curso de fiscalização ou análise, informa ao MP.

\section{Tribunal Superior Eleitoral}

O TSE passa a fazer parte da rede jurídica das TCE com a criação da Lei Complementar 135/2010 (Lei da Ficha Limpa).

- Recebe a lista com a relação de responsáveis com contas julgadas irregulares;

- Pode tornar esses responsáveis inelegíveis por 8 anos.

\section{Ministério da Transparência, Fiscalização e Controladoria- Geral da União (ex-CGU)}

Fiscalização e avaliação de programas de governo, os que incluem recursos advindos do orçamento da União. Realiza auditorias, avalia resultados de gestão e apura denúncias. (Controle interno e apoio ao controle externo)

- Recebe as TCE advindas de órgãos de controle externo;

- Instaura TCE;

- Envia TCE para o TCU para serem julgadas.

\section{Ministério Público junto ao TCU(MP)}

Atua junto ao Tribunal de Contas da União, para tomar providencias cabíveis ao arresto de bens dos responsáveis julgados em débito nas TCE.

- Autorizar a cobrança judicial da dívida.

- Determinar o desconto integral ou parcelado da dívida nos vencimentos, salários ou proventos do responsável.

\section{Advocacia Geral da União}

- Executa as cobranças advindas do MPTCU.

Figura 1: Parte da rede jurídica envolvida na tomada de contas especial. 


\section{Descrição da Rede de Relações Estabelecidas entre Juristas e Executores da lei}

Os órgãos supracitados se entrelaçam e executam diferentes funções no processo de tomada de contas especial. Cada órgão foi descrito detalhadamente em relação as suas respectivas atribuições.

\section{Ministérios e outros órgãos do Poder Judiciário e Legislativo}

Os ministérios são parte importante da rede de relações estabelecidas relacionada às TCE, já que administram e distribuem parte dos recursos da União com estados, municípios e Distrito Federal, através de convênios e contratos. Desde 17 de março de 2016, existem 23 ministérios e 9 (nove) secretarias e órgãos com status de ministério (quatro secretarias e cinco órgãos ligados à Presidência da República). Cada ministério é responsável por uma área específica e administra uma dotação orçamentária oriunda de um orçamento da União.

Os ministérios são subordinados à Presidência da República e consequentemente integram a Administração Pública Federal. Estes possuem autonomia técnica, financeira e administrativa para executar as ações das suas áreas de competência. Algumas das funções dos ministérios são de estabelecer estratégias, diretrizes e prioridades na aplicação de recursos públicos, além de estabelecer normas, acompanhar e avaliar programas federais (Portal Brasil, 2016).

O decreto $n^{\circ} 6.170$, de julho de 2007 , no art. $1^{\circ}$, regulamenta o repasse do dinheiro advindo da União.

Art. $I^{\underline{o}}$ Este Decreto regulamenta os convênios, contratos de repasse e termos de execução descentralizada celebrados pelos órgãos e entidades da administração pública federal com órgãos ou entidades públicas ou privadas sem fins lucrativos, para a execução de programas, projetos e atividades que envolvam a transferência de recursos ou a descentralização de créditos oriundos dos Orçamentos Fiscal e da Seguridade Social da União.

Cabe ao gestor público do contrato/convênio acompanhar a prestação de contas conforme descrito no decreto $\mathrm{n}^{\circ} 6.170$, de julho de 2007 . 
$\S 6^{\circ}$ A prestação de contas no âmbito dos convênios e contratos de repasse observará regras específicas de acordo com o montante de recursos públicos envolvidos, nos termos das disposições $e$ procedimentos estabelecidos no ato conjunto de que trata o caput do art. 18.

$\S 7$ A A prestação de contas inicia-se concomitantemente com a liberação da primeira parcela dos recursos financeiros que deverá ser registrada pelo concedente no SICONV

$\S$ 8- O prazo para análise da prestação de contas e a manifestação conclusiva pelo concedente será de um ano, prorrogável no máximo por igual período, desde que devidamente justificado.

$\$ 9^{\circ}$ Constatada irregularidade ou inadimplência na apresentação da prestação de contas $e$ comprovação de resultados, a administração pública poderá, a seu critério, conceder prazo de até 45 dias para a organização da sociedade civil sanar a irregularidade ou cumprir a obrigação

$\S 10^{\circ}$. A análise da prestação de contas pelo concedente poderá resultar em:

I-aprovação

II - aprovação com ressalvas, quando evidenciada impropriedade ou outra falta de natureza formal de que não resulte dano ao erário; ou;

III - rejeição com a determinação da imediata instauração de tomada de contas especial.

Os ministérios relacionam-se com a rede de relações jurídica, tendo em vista que enquanto autoridades administrativas são responsáveis por acompanhar os prazos da prestação de contas. Além disso, realizarão a análise de contas fornecidas pela concedente. Na análise poderão aprovar, aprovar com ressalvas ou rejeitar as contas. Uma vez realizada a análise, deverão instaurar a tomada de contas especial e enviá-las à CGU.

Além dos ministérios, existem outros órgãos que fazem parte da rede de relações estabelecidas na administração pública direta: os órgãos públicos ligados diretamente ao poder executivo federal, estadual ou municipal. Esses são responsáveis imediatos pelas atividades administrativas do estado. A administração pública indireta caracteriza-se por entidades que possuem patrimônio, autonomia administrativa e orçamento específico para seus fins e de responsabilidade de gestão. Como por exemplo: as autarquias, as fundações públicas, empresas públicas e sociedades de economia mista.

\section{Ministério da Transparência, Fiscalização e Controladoria-Geral da União}

O Ministério da Transparência, Fiscalização e Controladoria-Geral da União está estruturado em quatro unidades finalísticas, que atuam de maneira articulada. As unidades são: 1) Secretaria de Transparência e Prevenção da Corrupção (STPC); 2) Secretaria Federal de Controle Interno (SFC); 3) Corregedoria-Geral da União (CRG) e 4) Ouvidoria Geral da União 
(OGU). No que se refere à tomada de contas especial, duas secretarias participam ativamente do processo, a Secretaria Federal de Controle Interno e a Corregedoria-Geral da União.

A Secretaria Federal de Controle Interno (SFC) executa atividades de controle interno do Poder Executivo Federal. Sendo assim, a fiscalização e avaliação de programas de governo, os que incluem recursos advindos do orçamento da União. O processo envolve auditorias e avaliação dos resultados da gestão dos administradores públicos federais, apuração de denúncias e representações, e execução de atividades de apoio ao controle externo. A Corregedoria-Geral da União (CGU) trabalha no combate à impunidade na Administração Pública Federal. Promove, coordena e acompanha a execução de ações disciplinares, objetivando à apuração de responsabilidade administrativa de servidores públicos (CGU, 2013). As competências da CGU foram definidas pela Lei $\mathrm{n}^{\circ} 10.683$, de 28 de maio de 2003 e pelo Decreto $\mathrm{n}^{\mathrm{o}} 8.109$, de 17 de setembro de 2013.

Decreto ${ }^{\circ} 8.109$ de Setembro de 2003

Art. $1^{o}$ A Controladoria-Geral da União, órgão central do Sistema de Controle Interno do Poder Executivo federal e integrante da estrutura da Presidência da República, dirigida pelo Ministro de Estado Chefe da Controladoria-Geral da União, tem como competência assistir direta e imediatamente o Presidente da República no desempenho de suas atribuições quanto aos assuntos e providências, no âmbito do Poder Executivo federal, relativos a:

I - defesa do patrimônio público;

II - controle interno;

III - auditoria pública;

IV - correição;

$V$ - prevenção e combate à corrupção;

VI - atividades de ouvidoria; $e$

VII - incremento da transparência da gestão.

$\S 1^{o}$ Compete à Controladoria-Geral da União exercer a supervisão técnica dos órgãos que compõem o Sistema de Controle Interno, o Sistema de Correição e das unidades de ouvidoria do Poder Executivo federal, e prestar orientação normativa na condição de órgão central.

$\S 2^{\circ} A$ Controladoria-Geral da União prestará orientação aos dirigentes públicos $e$ administradores de bens e recursos públicos quanto a correição, controle interno, prevenção da corrupção e ouvidoria.

Art. $2^{\circ}$ A Controladoria-Geral da União encaminhará à Advocacia-Geral da União os casos que configurem improbidade administrativa e os casos para os quais se recomendem a indisponibilidade de bens, o ressarcimento ao erário e outras providências a cargo daquele órgão, e provocará, sempre que necessária, a atuação do Tribunal de Contas da União, da Secretaria da Receita Federal do Brasil do Ministério da Fazenda, dos órgãos do Sistema de Controle Interno do Poder Executivo federal e, quando houver indícios de responsabilidade penal, do Departamento de Polícia Federal do Ministério 
da Justiça e do Ministério Público, inclusive quanto a representações ou denúncias que se afigurarem manifestamente caluniosas.

O Ministério da Transparência, Fiscalização e Controladoria-Geral da União terá duas funções principais em relação a tomada de contas especial. Quando a TCE é instaurada no órgão ou entidade, tem 45 dias para ser enviada ao Ministério da Transparência, Fiscalização e Controladoria-Geral da União e este tem até 180 dias para enviar o processo para o Tribunal de Contas da União (TCU).

Ao receber um processo de TCE, o Ministério da Transparência, Fiscalização e Controladoria-Geral da União irá analisar os seguintes aspectos:

a) se está composto das peças estabelecidas no art. 10 da IN/TCU nº 71/2012;

b) se há pressupostos para sua instauração, com a devida ocorrência de dano ao erário;

c) se as medidas administrativas adotadas pela autoridade competente foram adequadas;

d) se foram cumpridas as normas para instauração e desenvolvimento da TCE;

e) se o responsável foi devidamente identificado e notificado, se o dano está corretamente quantificado e se os fatos estão adequadamente descritos.

Caso o processo não esteja devidamente formalizado, a CGU devolve-o ao órgão instaurador, em diligência, para que sejam apuradas as inconsistências. Se o processo estiver corretamente formalizado, ele é encaminhado à Pasta Ministerial para posteriormente encaminhar ao TCU para julgamento.

Além do encaminhamento formal das TCE recebidas, a própria CGU poderá ainda instaurar as TCE. Ela o faz através de ações coordenadas que podem se originar em outros órgãos do governo federal ou pela própria decisão da CGU em decorrência de denúncias, operações especiais e avaliações de programas do governo.

A Ação de controle que se origina por meio de solicitação em outros órgãos do governo federal ou de decisão da própria CGU. 
As Auditorias Especiais são realizadas pelos órgãos públicos federais. Esses trabalhos originam-se das solicitações de autoridades do próprio governo ou ainda de decisões tomadas na CGU. Por exemplo, denúncias veiculadas na imprensa ou mesmo na avaliação de risco desenvolvida pelo órgão central de Controle Interno do Poder Executivo Federal.

Denúncias, requisições de ações de controle e pedidos de informação encaminhados à CGU por órgãos da Administração Pública.

Pelo disposto na Lei ${ }^{\circ} 10.683 / 2003$, fica sob responsabilidade da Controladoria-Geral da União (CGU), acompanhar as representações ou denúncias relativas à lesão ou ainda a ameaça de lesão ao patrimônio público. É responsabilidade também da CGU, a execução das ações de controle sempre que avaliarem pertinentes.

Entende-se por demandas externas ${ }^{3}$ as denúncias, requisições de ações de controle e mesmo pedidos de informação sobre a aplicação de recursos públicos federais encaminhados à CGU. Podem ser feitos por administradores públicos, representantes de entidades, cidadãos e outros. As investigações são compiladas no Relatório de Demandas Externas, e são enviadas ao gestor para que este manifeste-se no que diz respeito às impropriedades/irregularidades que tenham sido identificadas. Os resultados são sumarizados nos Relatórios Anuais de Auditoria sobre a Prestação de Contas dos responsáveis pelos órgãos ou entidades, e consequentemente, enviados ao Tribunal de Contas da União. Quando for necessário, esses ainda são enviados à Polícia Federal e ao Ministério Público.

\footnotetext{
${ }^{3}$ As demandas externas são as TCE originadas de outros órgãos ou mesmo denúncias que não oriundas do Ministério da Transparência, Fiscalização e Controladoria-Geral da União.
} 


\section{Operações Especiais}

As operações especiais são conduzidas em parceria com outros órgãos de defesa do Estado, como por exemplo, o Departamento da Polícia Federal (DPF) e o Ministério Público, tanto âmbito Federal como no Estadual.

Avaliação de Programas do Governo

1- Programa de Fiscalização em Entes Federativos

O Programa de Fiscalização em Entes Federativos permite à CGU avaliar e verificar o uso previsto dos recursos públicos, transferidos a Estados, municípios e Distrito Federal através de programas e ações do Governo Federal. O programa atualmente realiza a seleção dos municípios por sorteios públicos e apresentam uma metodologia considerada nova por meio de análise de indicadores de vulnerabilidade.

1.1 - Sorteio Público

O Programa de Fiscalização por Sorteios iniciou em 2003 e, de acordo com o site da CGU (2016), “a cada sorteio são definidos 60 municípios, onde os auditores da CGU examinam contas e documentos, além de inspeção pessoal e física das obras e serviços em realização". Podem ser realizados até três sorteios anuais, assim podem ser fiscalizados até 180 municípios em um ano, dentro de 5.561 municípios no Brasil (IBGE, 2016).

\subsection{Matriz de Vulnerabilidade}

Na Matriz de Vulnerabilidade, a CGU sinaliza as fragilidades na aplicação dos recursos públicos federais que são direcionados a estados, municípios e Distrito Federal. Cada ente federativo recebe uma nota, e a partir disso, são estabelecidos indicadores que são agrupados em quatro aspectos: 1- Desenvolvimento Econômico-Social; 2- Materialidade; 3Transparência e 4- Controle. Os indicadores são construídos a partir de dados pré-existentes 
nos sistemas de informação governamentais e oriundos de informações produzidas pela própria CGU. Os entes federativos são escolhidos de acordo com a pontuação obtida em cada indicador.

2- Avaliação da Execução de Programas de Governo

A CGU avalia programas de Governos de uma amostra selecionada aleatoriamente e que representem o universo significativo de recursos federais aplicados. A seleção dá-se através de uma hierarquização dos programas constantes da Lei Orçamentária Anual (LOA), são utilizados critérios como: relevância, materialidade e criticidade.

De acordo com dados do site da CGU (2016), a Secretaria Federal de Controle Interno (SFC) executou auditorias, de $1^{\circ}$ de janeiro de 2002 a 31 de dezembro de 2015, em processos de tomada de contas especial, tendo sido realizadas 24.987 análises. Dessas análises, 20.293 contas foram avaliadas irregulares, sendo o equivalente $81,21 \%$ das análises. Esses processos foram enviados ao Tribunal de Contas da União (TCU), para julgamento, com retorno potencial aos cofres do Tesouro Nacional da ordem de R $\$ 15,868$ bilhões (CGU, 2016). Estima-se que somente $1 \%$ do total de recursos desviados sejam recuperados pelo TCU (cf. Teixeira, 2006).

Na Tabela 2 observa-se, que dos processos analisados, 4.694 referem-se a análises de processos que foram devolvidos (para diligência) aos órgãos/entidades instauradores, para fins de revisão e/ou complementação de dados. 
Tabela 2

Análises de processos de Tomada de contas especial (TCE) efetuadas pela CGU

\begin{tabular}{ccccc}
\hline Exercícios & $\begin{array}{c}\text { Análises de } \\
\text { TCE } \\
\text { Efetuadas }\end{array}$ & $\begin{array}{c}\text { Diligenciadas } \\
\text { ao Orgão de } \\
\text { Origem }\end{array}$ & $\begin{array}{c}\text { Certificadas } \\
\text { ao TCU }\end{array}$ & Retorno Potencial R\$ \\
\hline $2002-2009$ & 13.409 & 2.922 & 10.487 & $4.249 .716 .084,03$ \\
2010 & 1.481 & 375 & 1.106 & $1.685 .274 .158,37$ \\
2011 & 1.149 & 405 & 744 & $1.783 .167 .841,61$ \\
2012 & 1.688 & 414 & 1.274 & $1.453 .300 .009,34$ \\
2013 & 2.127 & 204 & 1.923 & $2.520 .489 .158,45$ \\
2014 & 2.500 & 178 & 2.322 & $1.381 .037 .790,38$ \\
2015 & 2.638 & 200 & 2.438 & $2.795 .822 .701,49$ \\
\hline TOTAL & 24.992 & 4.698 & 20.294 & $15.868 .807 .743,67$ \\
\hline
\end{tabular}

Atualizado até $31 / 12 / 2015$

\section{Tribunal de Contas da União}

O Tribunal de Contas da União (TCU) foi criado no nascimento da República, pelo Decreto 966-A, de 7 de novembro de 1890, que passa então a fazer parte da Constituição de 1981 (Gregório, 2012). O TCU funciona como um tribunal administrativo. É um órgão colegiado, e as deliberações são realizadas no Plenário (instância máxima que reúne todos os ministros), na Primeira Câmara e na Segunda Câmara (colegiados nos quais os ministros se dividem).

As competências do Tribunal de Contas da União estão descritas nos art. 70 e 71 da Constituição Federal, c/c o art. $1^{\circ}$, da Lei nº. 8.443, de 16.07.1992 (Lei Orgânica do Tribunal de Contas da União). Cabe ao TCU julgar as contas dos administradores e demais responsáveis por dinheiros, bens e valores públicos. Além disso, deve proceder à fiscalização contábil, financeira, orçamentária, operacional e patrimonial dos órgãos e entidades da União, bem como 
apreciar as contas prestadas anualmente pelo Presidente da República e analisar a legalidade dos atos de admissão de pessoal na administração direta e indireta e das concessões de aposentadorias, reformas e pensões (cf. Costa, 2006). As atribuições do TCU são de função fiscalizadora, opinativa, julgadora, sancionadora, corretiva, consultiva, informativa, ouvidora e normativa (cf. Fernandes, 2008).

De acordo com Costa et al. (2003), os Tribunais de Contas amparados por suas competências constitucionais desempenham, dentre outras, as seguintes atividades principais:

- Auxiliam o Poder Legislativo em suas atribuições de efetuar o julgamento político do agente titular de cada poder, emitindo parecer prévio recomendando a aprovação ou rejeição de suas contas;

- Julgam as contas dos ordenadores de despesa e demais responsáveis por dinheiros, bens e valores públicos da administração direta e indireta, e as contas daqueles que derem causa a perda, extravio ou outra irregularidade de que resulte prejuízo ao erário. Além disso, emitem decisões, reprovando ou aprovando, com ou sem ressalvas, as contas prestadas ou a tomada de contas especial;

- Procedem, por iniciativa própria ou por solicitação das casas legislativas, à fiscalização contábil, financeira, orçamentária, operacional e patrimonial dos poderes das respectivas esferas de governo e das demais entidades referidas no item anterior;

•. Apreciam, mediante a emissão de acórdão, a legalidade dos atos de admissão de pessoal, na administração direta e indireta, bem como a das concessões de aposentadorias, reformas e pensões, ressalvadas as melhorias posteriores que não alterem o fundamento legal do ato concessório.

A Constituição no inciso II do art. 71 afirma que as contas dos administradores e demais responsáveis por dinheiro, bens e valores públicos deverão ser julgadas pelo TCU. Estão 
incluídas nesta competência "as fundações e sociedades instituídas e mantidas pelo Poder Público federal, e as contas daqueles que derem causa a perda, extravio ou outra irregularidade de que resulte prejuízo ao erário público" (cf. Brasil, 2012, p. 56). Cabe ainda ao TCU a apreciação da "legalidade dos atos de admissão de pessoal, a qualquer título, na administração direta e indireta, incluídas as fundações instituídas e mantidas pelo Poder Público, excetuadas as nomeações para cargo de provimento em comissão, bem como a das concessões de aposentadorias, reformas e pensões" (cf. Brasil, 2012, p. 56).

Outra competência listada no art. 71 da Constituição trata da fiscalização da aplicação de quaisquer recursos repassados pela União mediante convênio, acordo, ajuste ou outros instrumentos congêneres, a Estado, ao Distrito Federal ou a Município. A regra do inciso VI do art. 71 do texto constitucional exige a comprovação por parte dos Estados, Municípios e Distrito Federal dos gastos e da maneira como foram utilizados os recursos públicos recebidos mediante convênios ou contratos.

A fiscalização em questão pode ser feita pelo Tribunal de Contas da União tendo como foco, também, o órgão ou entidade da União que efetuou o repasse. Assim, tanto o responsável pelo repasse (por exemplo, ministérios) quanto as entidades recebedoras do recurso (por exemplo, prefeituras) deverão prestar contas ao TCU. Cabe ressaltar que o inciso VI trata especificamente de repasses efetuados pela União de recursos originariamente federais. Ainda em relação às competências exclusivas do Tribunal de Contas da União, o inciso VIII autoriza o TCU a "aplicar aos responsáveis, em caso de ilegalidade de despesa ou irregularidade de contas, as sanções previstas em lei, que estabelecerá, entre outras cominações, multa proporcional ao dano causado ao erário" (cf. Brasil, 2012, p. 56). 


\section{Tribunal Superior Eleitoral (TSE)}

O Tribunal Superior Eleitoral é órgão máximo da Justiça Eleitoral, e suas competências foram definidas pela Constituição Federal e pelo Código Eleitoral da Lei no 4.737, de julho de 1965. O TSE passa a fazer parte da rede jurídica das TCE em 2010 com a criação da Lei Complementar 135/2010 (Lei da Ficha Limpa) relacionada ao disposto no art. 11, § 5º da Lei $n^{\circ} 9.504$, de 1997.

O responsável que tiver as contas relativas ao exercício de cargos ou funções públicas rejeitadas por irregularidade não pode se candidatar a cargo eletivo nas eleições que se realizarem nos oito anos seguintes à data da condenação. Além disso, o registro de candidatura poderá ser impugnado a pedido de candidatos, partidos políticos ou coligações concorrentes no prazo de cinco dias contados da publicação do edital do pedido de registro, utilizando como base da petição as informações contidas na lista do TCU.

Desde então, o Tribunal de Contas da União gera uma lista com a relação de responsáveis com contas julgadas irregulares durante os oito anos que precedem a eleição, e envia ao TSE até o dia 5 de julho do ano em que se realizarem as eleições.

\section{Ministério Público junto ao Tribunal de Contas da União (MPTCU)}

O MPTCU tem como missão guardar a Lei Orgânica e fiscalizar a sua execução. Podem autorizar cobranças judiciais da dívida e tomar medidas necessários ao arresto de bens dos responsáveis julgados em débito.

A lei n8.429, de 2 de junho de 1992, “dispõe sobre as sanções aplicáveis aos agentes públicos nos casos de enriquecimento ilícito no exercício de mandato, cargo, emprego ou função na administração pública direta, indireta ou fundacional e dá outras providências" (Presidência da República, 1992). A lei refere-se ainda a questão ligada ao Ministério Público junto ao TCU nos seguintes artigos dessa lei: 
Art. 7. Quando o ato de improbidade causar lesão ao patrimônio público ou ensejar enriquecimento ilícito caberá a autoridade administrativa responsável pelo inquérito representar ao Ministério Público, para a indisponibilidade dos bens do indiciado.

Art. 15. A comissão processante dará conhecimento ao Ministério Público e ao Tribunal ou Conselho de Contas da existência de procedimento administrativo para apurar a prática de ato de improbidade.

Parágrafo único. O Ministério Público ou Tribunal ou Conselho de Contas poderá, a requerimento, designar representante para acompanhar o procedimento administrativo.

Art. 16. Havendo fundados indícios de responsabilidade, a comissão representará ao Ministério Público ou à procuradoria do órgão para que requeira ao juízo competente a decretação do sequestro dos bens do agente ou terceiro que tenha enriquecido ilicitamente ou causado dano ao patrimônio público.

Art. 17. A ação principal, que terá o rito ordinário, será proposta pelo Ministério Público ou pela pessoa jurídica interessada, dentro de trinta dias da efetivação da medida cautelar.

$\S 3{ }^{o}$ No caso de a ação principal ter sido proposta pelo Ministério Público, aplica-se, no que couber, o disposto no $\$ 3^{\circ}$ do art. 6 da Lei $n^{o} .717$, de 29 de junho de 1965.

$\S 4^{\circ} O$ Ministério Público, se não intervir no processo como parte, atuará obrigatoriamente, como fiscal da lei, sob pena de nulidade.

A relação prevista entre Tribunal de Contas da União e Ministério Público está prevista

na Lei $n^{\circ} 8443 / 92$, art. 28, art. 61 e art.81.

Art. 28. Expirado o prazo a que se refere o caput do art. 25 desta Lei, sem manifestação do responsável, o Tribunal poderá:

I - determinar o desconto integral ou parcelado da dívida nos vencimentos, salários ou proventos do responsável, observados os limites previstos na legislação pertinente; ou

II - autorizar a cobrança judicial da divida por intermédio do Ministério Público junto ao Tribunal, na forma prevista no inciso III do art. 81 desta Lei.

Art. 61. O Tribunal poderá, por intermédio do Ministério Público, solicitar à Advocacia-Geral da União ou, conforme o caso, aos dirigentes das entidades que lhe sejam jurisdicionadas, as medidas necessárias ao arresto dos bens dos responsáveis julgados em débito, devendo ser ouvido quanto à liberação dos bens arrestados e sua restituição.

Art. 81. Competem ao procurador-geral junto ao Tribunal de Contas da União, em sua missão de guarda da lei e fiscal de sua execução, além de outras estabelecidas no Regimento Interno, as seguintes atribuições:

I - promover a defesa da ordem jurídica, requerendo, perante o Tribunal de Contas da União as medidas de interesse da justiça, da administração e do erário;

II - comparecer às sessões do Tribunal e dizer de direito, verbalmente ou por escrito, em todos os assuntos sujeitos à decisão do Tribunal, sendo obrigatória sua audiência nos processos de tomada ou prestação de contas e nos concernentes aos atos de admissão de pessoal e de concessão de aposentadorias, reformas e pensões;

III - promover junto à Advocacia-Geral da União ou, conforme o caso, perante os dirigentes das entidades jurisdicionadas do Tribunal de Contas da União, as medidas previstas no inciso II do art. 28 e no art. 61 desta Lei, remetendo-lhes a documentação e instruções necessárias;

$I V$ - interpor os recursos permitidos em lei. 
O Ministério Público pode atuar junto ao Tribunal de Contas da União, para tomar providencias cabíveis ao arresto de bens dos responsáveis julgados em débito.

A rede de relações pode ser resumida conforme descrito abaixo:

\section{MINISTÉRIOS E OUTROS ÓRGÃOS DO PODER JUDICÍARIO E LEGISLATIVO}

a) Aplica diretamente recursos da União

b) Transfere recursos para entes públicos e privados

c) Controla a aplicação dos recursos transferidos, se analisada a irregularidade, instaura a TCE e envia à CGU.

MINISTÉRIO DA TRANSPARÊNCIA, FISCALIZAÇÃO E CONTROLADORIA-

\section{GERAL DA UNIÃO}

a) Pode instaurar as TCE através de ações coordenadas que podem se originalizar dentro do governo federal ou pela própria decisão da CGU, denúncias, operações especiais e avaliações de programas do governo.

b) Analisa as TCE recebidas, em caso de falha no processo devolve ao órgão que instaurou. Se o processo tiver correto, tem 180 para analisar e enviar ao TCU.

\section{TRIBUNAL DE CONTAS DA UNIÃO (TCU)}

a) Julga as contas dos administradores e demais responsáveis por dinheiros, bens e valores públicos.

b) Fiscaliza da aplicação de quaisquer recursos repassados pela União mediante convênio, acordo, ajuste ou outros instrumentos congêneres, a Estado, ao Distrito Federal ou a Município.

c) Autoriza, por intermédio do Ministério Público junto ao TCU, a cobrança judicial da dívida. 


\section{MINISTÉRIO PÚBLICO JUNTO AO TRIBUNAL DE CONTAS DA UNIÃO (MPTCU)}

a) Atua junto ao Tribunal de Contas da União, para tomar providencias cabíveis ao arresto de bens dos responsáveis julgados em débito.

\section{Análise da Rede Jurídica para a Tomada de Contas Especial}

O conceito de rede pode ser definido como entrelaçamento de estruturas, nesse caso específico a um entrelaçamento de órgãos envolvidos na tomada de contas especiais. Essa rede jurídica inicia-se no órgão ou entidade que recebeu recuso da União.

A rede jurídica estabelece contingências entrelaçadas, começando quando o gestor de recurso público: (1) arrecadar, (2) gerenciar, (3) utilizar e (4) administrar os recursos públicos ou valores recebidos da União. Essas atividades antecedem ao comportamento da má gestão, ou seja, atos que geram dano ao erário (previstas no art. 16 da lei 8.443 nas alíneas "a", "b", “c”, e "d”). Para esses comportamentos são previstos várias punições, sendo a primeira delas, o gestor se tornar réu em uma TCE. A identificação do dano ao erário por parte da autoridade administrativa é um estímulo discriminativo para que este venha a impor medidas administrativas a fim de identificar os responsáveis, quantificar o dano e recuperar o dinheiro. Caso a autoridade administrativa não tome as medidas cabíveis e descritas na lei, a mesma pode ser incluída por responsabilidade solidária. Ainda dentro do órgão que ocorreu a má gestão do recuso, já existe uma relação entre a contingência jurídica, sendo uma estabelecida para o gestor e outra para a autoridade administrativa.

Uma vez que todas as medidas administrativas tiverem sido executadas e ainda assim não ocorrer a prestação de contas e nem se reaver o dano ao erário quantificado, uma TCE é instaurada e enviada a Controladoria Geral da União (este órgão compõe a rede jurídica). A CGU ao receber e avaliar o pedido de abertura da TCE pode devolver o processo ao órgão instaurador em diligência para seja sanada inconsistências processuais ou encaminhar a TCE 
para o TCU no prazo de 180 dias, caso o processo tenha sido corretamente formalizado. Se os prazos estabelecidos na lei não forem cumprimos e nem solicitado prorrogação de prazo, o responsável pela avaliação do processo pode ser incluído na TCE por responsabilidade solidária (podendo observar três contingências, descritas na Figura 1).

Entre o órgão ou entidade que ocorreu o dano e a CGU, nota-se três contingências jurídicas, diagramada na Figura 2.

Contingência 1

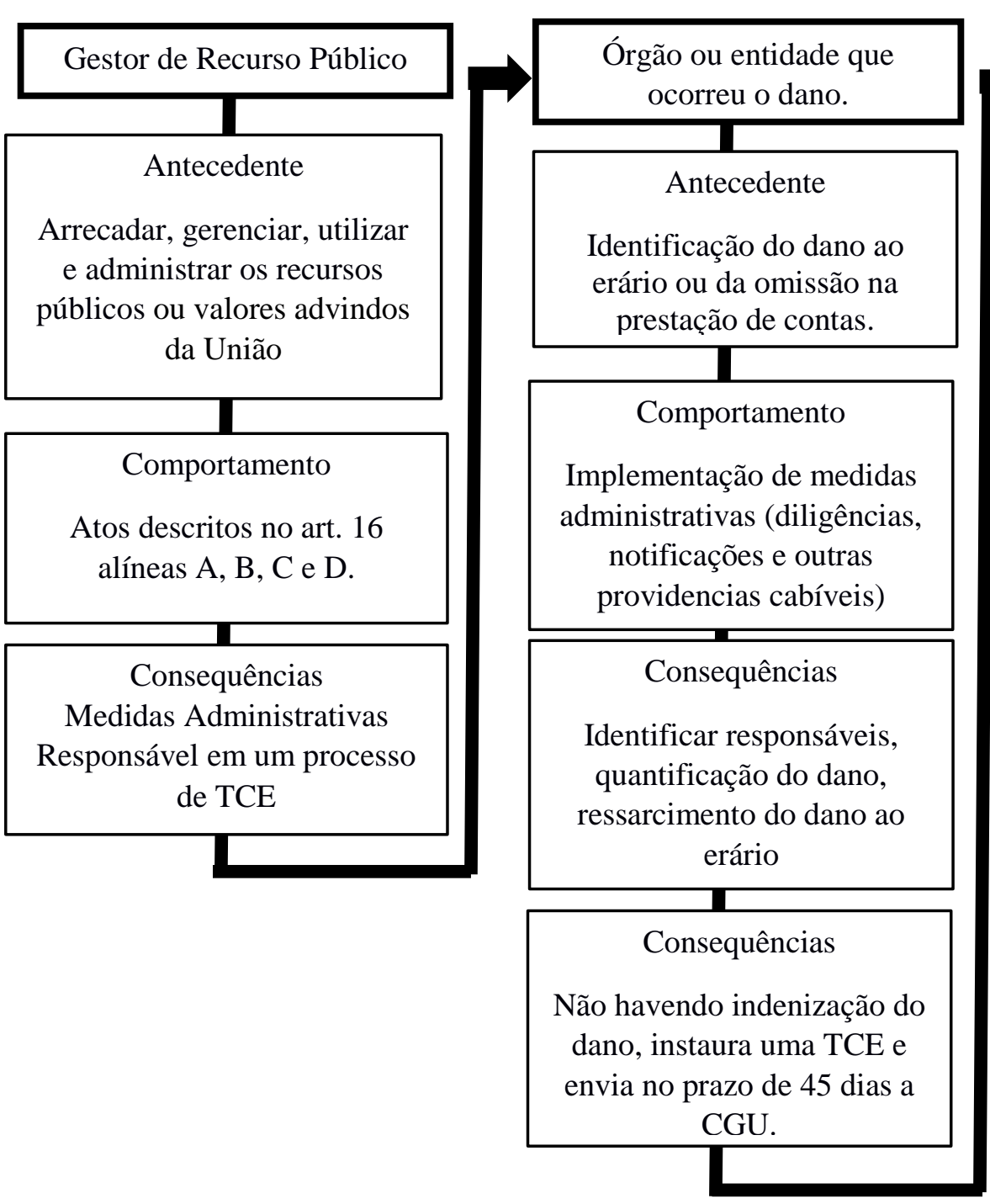

$\underline{\text { Contingência } 3}$

Controladoria Geral da União<smiles>[C]1C[C]2C[C]12</smiles>

\begin{tabular}{|c|}
\hline Antecedente \\
Recebimento da TCE pelo \\
órgão instaurador
\end{tabular}

Figura 2. Parte da rede jurídica envolvendo gestor de recurso público, autoridade administrativa e Controladoria Geral da União. 
Se as contas foram julgadas como irregulares, o TCU poderá aplicar algumas sanções como: multa, cobrança do dano ao erário com juros ou a sanção de inabilitação para o exercício de cargos públicos podendo variar de 5 a 8 anos. Contudo, o TCU não executa as cobranças. Assim, os processos são encaminhados ao Ministério Público para autorizarem a cobrança judicial do dano ao erário. O MPTCU pode autorizar a cobrança judicial da dívida e até mesmo, determinar o desconto integral ou parcelado da dívida nos vencimentos, salários ou proventos do responsável (fato que ocorre com servidores e funcionários públicos).

Uma outra contingência que pode ser observada nessa rede de relações ocorre quando o TCU, ao analisar a TCE, identifica indícios de fraude. Este irá encaminhar a denúncia para o MP que procederá às investigações. Nenhum processo criminal é instaurado pelo TCU.

Além de encaminhar as cobranças para o MPTCU e o TCU, a cada dois anos, compila uma lista com a relação de responsáveis com contas julgadas irregulares e envia ao Tribunal Superior Eleitoral que poderá aplicar uma sanção de inelegibilidade de 8 anos.

As sanções envolvendo inelegibilidade, pagamento do dano ao erário, as multas e mesmo a sanção de inabilitação para exercício de cargos públicos são consequências atrasadas que podem levar anos para acontecerem. A média de duração de um processo no TCU é de 4 anos, fora os demais prazos que deverão ser cumpridos antes mesmo da TCE chegar no TCU. Essa outras 4 contingências jurídicas podem ser observadas na Figura 3

A compreensão da rede jurídica é de suma importância pois as sanções previstas na Lei 8.443/92 e complementada pelo Regimento Interno do TCU perpassam por todos esses órgãos. Para aprofundar na análise, foi descrito as contingências especificadas na lei. 
Contingência 4

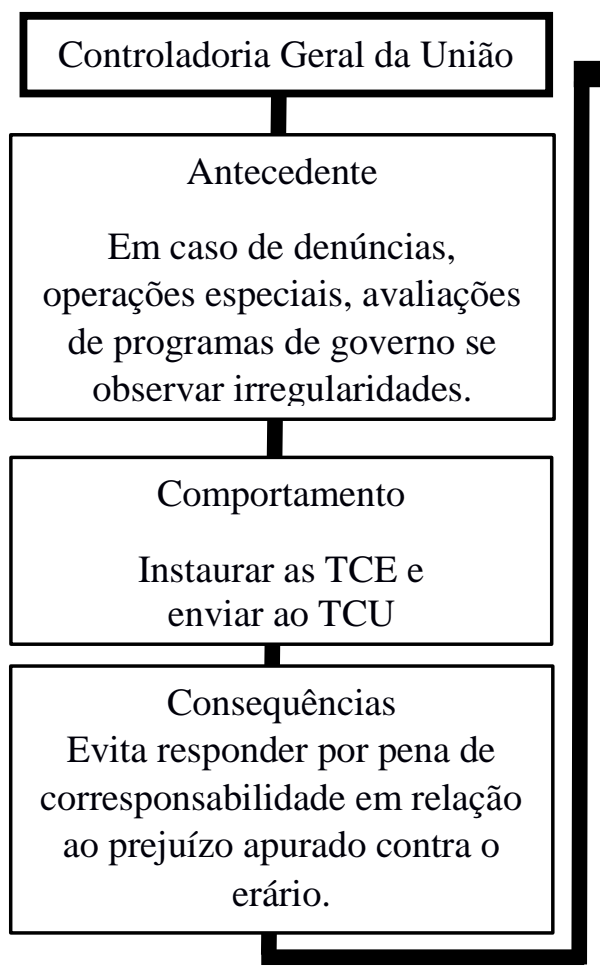

Contingência 7

\begin{tabular}{|c|}
\hline Tribunal Superior Eleitoral \\
\hline Antecedente \\
$\begin{array}{c}\text { Recebe a lista com a relação de } \\
\text { responsáveis com contas } \\
\text { julgadas irregulares. }\end{array}$ \\
\hline Comportamento \\
$\begin{array}{c}\text { Pode tornar esses responsáveis } \\
\text { inelegíveis por } 8 \text { anos. }\end{array}$ \\
\hline Consequência \\
Aumento da idoneidade dos \\
candidatos em âmbito nacional
\end{tabular}

Contingência 5

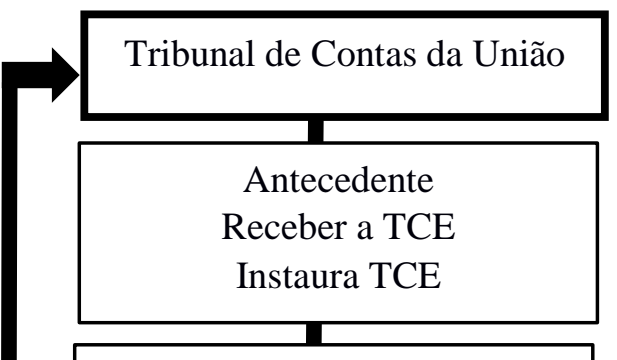

Comportamento

Analisa e julga as TCE

Em caso de julgamento de

contas irregulares aplicação das sanções

Comportamento

Envia pedidos de cobrança ao MPTCU.

Quando identificado indícios de fraude ou de qualquer outro crime no curso de fiscalização ou análise, informa ao MP.

\section{Comportamento}

Envia lista com o nome dos condenados ao TSE.

Contingência 6

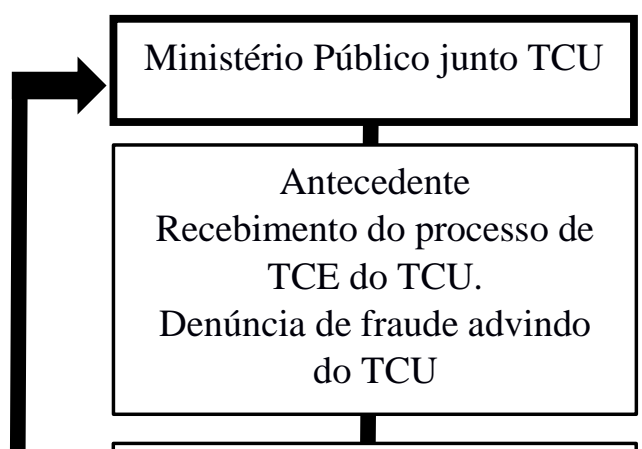

\section{Comportamento}

Autorizar a cobrança judicial da dívida.

Determinar o desconto integral ou parcelado da dívida nos vencimentos, salários ou proventos do responsável.

\section{Comportamento}

Instauração de processo de investigação de fraude.

Consequências

Reaver o dano ao erário

\section{Consequência para o} gestor do recurso

Consequências

Nenhuma prevista em lei

Advocacia Geral da União

Execução da dívida.

Figura 3. Parte da rede jurídica envolvendo Controladoria Geral da União, Tribunal de Contas

da União, Tribunal Superior Eleitoral e Ministério Público. 


\section{Lei Específica para a Tomada de Contas Especial}

A análise da legislação teve por objetivo descrever duas contingências aninhadas: 1Análise Comportamental de Normas Jurídicas (Premissas Comportamentais - Contingência Jurídica - Meta Social) e 2- As contingências jurídicas (Contexto - Comportamento Consequências).

\section{Lei $\mathrm{n}^{\circ} 8.443$ de julho de 1992}

A Lei Orgânica do Tribunal de Contas da União - Lei 8443/92 enfatiza atos relacionados à prestação de contas, ou seja, a recursos recebidos cuja destinação precisa ser justificada e comprovada. $\mathrm{O}$ art. $8^{\circ}$ da Lei deixa claro que a tomada de contas especial (TCE) se relaciona à prestação de contas, ou seja, dinheiro recebido da União cuja utilização precisa ser justificada e documentada.

Na Tabela 3 pode-se observar a descrição do art. 8 da lei n. 8.443/92 de acordo com a Análise Comportamental do Direito da norma jurídica e da contingência jurídica. Na primeira coluna, observa-se a premissa comportamental que indica que os comportamentos seguidos por punição tendem a diminuir em termos de probabilidade de ocorrência se a contingência jurídica for aplicada, ou seja, as sanções previstas em leis forem aplicadas sobre o comportamento, então, metas sociais podem ser alcançadas. Nesse caso específico, reduzir comportamentos associados a má gestão de recursos públicos, reduzir a ilegalidade na prestação de contas de recursos público e coibir o dano ao erário.

Nessa tabela, é possível observar a descrição da contingência jurídica aninhada a essa contingência maior. Sendo analisados os possíveis antecedentes desses comportamentos, os comportamentos previstos no artigo e as consequências antevistas. A tabela descreve a análise comportamental da norma jurídica, contingência jurídica do responsável por uso de recurso, autoridade administrativa e controle interno. Essa análise será realizada para outros artigos e 
incisos previstos na Lei ${ }^{\circ}$ 8.443/92. Como todos os elementos da lei visam o alcance da mesma meta social, a norma jurídica foi descrita somente uma vez.

Se as contas do gestor forem julgadas irregulares pelo TCU e havendo débito, o responsável deverá pagar a dívida atualizada, acrescida a juros, conforme descrito no art. 19 e art. 57.

Art. 19. Quando julgar as contas irregulares, havendo débito, o Tribunal condenará o responsável ao pagamento da dívida atualizada monetariamente, acrescida dos juros de mora devidos, podendo, ainda, aplicar-lhe a multa prevista no art. 57 desta lei, sendo o instrumento da decisão considerado título executivo para fundamentar a respectiva ação de execução.

Art. 57.Quando o responsável for julgado em débito, poderá ainda o Tribunal aplicar-lhe multa de até cem por cento do valor atualizado do dano causado ao erário.

Tabela 3

Norma jurídica e contingência jurídica no art. 8 da Lei $n^{\circ} 8.443 / 92$ para os responsáveis de recursos públicos e autoridades administrativas.

\begin{tabular}{|c|c|c|}
\hline \multicolumn{3}{|c|}{ Análise Comportamental da Norma Jurídica } \\
\hline $\begin{array}{c}\text { DADO QUE } \\
\text { (Premissas Comportamentais) }\end{array}$ & SE (Contingência Jurídica) & $\begin{array}{c}\text { ENTÃO } \\
\text { (META SOCIAL) }\end{array}$ \\
\hline $\begin{array}{l}\text { - Comportamentos seguidos de } \\
\text { punição tendem a diminuir em } \\
\text { termos de probabilidade de } \\
\text { ocorrência. }\end{array}$ & $\begin{array}{l}\text { - se comportamentos associados } \\
\text { a má gestão de recursos } \\
\text { ocorrerem, diversas sanções } \\
\text { serão aplicadas. }\end{array}$ & $\begin{array}{l}\text { - reduzir comportamentos } \\
\text { associados a má gestão de } \\
\text { recursos públicos. } \\
\text { - reduzir a ilegalidade na } \\
\text { prestação de contas de recursos } \\
\text { público. } \\
\text { - coibir o dano ao erário. }\end{array}$ \\
\hline
\end{tabular}




\section{Tabela 3}

Norma jurídica e contingência jurídica no art. 8 da Lei $n^{\circ} 8.443 / 92$ para os responsáveis de recursos públicos e autoridades administrativas.

\section{Contingência jurídica (destinadas ao responsável por uso de recursos)}

\section{EVENTO ANTECEDENTE COMPORTAMENTO \\ CONSEQUENCIA}

- Arrecadar, gerenciar, utilizar e - omissão no dever de prestar - instauração da TCE

administrar os recursos públicos contas,

ou valores pelos quais a União responde.

- não comprovação da aplicação

dos recursos repassados pela

União, na forma prevista no

inciso VII do art. $5^{\circ}$ desta Lei

(convênios, acordos.)

- ocorrência de desfalque ou desvio de dinheiros, bens ou valores públicos

- prática de qualquer ato ilegal, ilegítimo ou antieconômico de que resulte dano ao erário.

\footnotetext{
Contingência jurídica (destinadas à autoridade administrativa)

EVENTO ANTECEDENTE

Tomar conhecimento de:

- omissão no dever de prestar contas,

- não comprovação da aplicação dos recursos repassados pela União, na forma prevista no inciso VII do art. $5^{\circ}$ desta Lei (convênios, acordos..)

- ocorrência de desfalque ou desvio de dinheiros, bens ou valores públicos

- prática de qualquer ato ilegal, ilegítimo ou antieconômico de que resulte dano ao erário

\section{COMPORTAMENTO}

- deixar de adotar imediatamente providências com vistas à instauração da tomada de contas especial para apuração dos fatos, identificação dos responsáveis e quantificação do dano

\section{CONSEQUENCIA}

- o Tribunal determinará a instauração da tomada de contas especial, fixando prazo para cumprimento dessa decisão.
} 
Na Tabela 4 foi analisado o art. 19 e art. 57. Pode-se observar nesses artigos a descrição dos comportamentos a serem punidos pela lei, como: omissão no dever de prestar contas, não comprovação da aplicação dos recursos repassados pela União, ocorrência de desfalque ou desvio de dinheiros, bens ou valores públicos e prática de qualquer ato ilegal, ilegítimo ou antieconômico de que resulte dano ao erário.

É prevista consequência para o gestor como débito (devolução dos valores corrigidos), multa proporcional ao débito, inabilitação por um período de cinco a oito anos para o exercício de cargo em comissão ou função de confiança no âmbito da Administração Pública, ou mesmo, arresto dos bens dos responsáveis julgados em débito. A análise incluiu descrever as contingências relacionadas ao gestor do recurso público e contingências destinadas a autoridade administrativas.

Tabela 4.

Contingência jurídica no art. 19 e art. 57 da Lei $n^{\circ}$ 8.443/92 para os responsáveis de recursos públicos, autoridades administrativas e controle interno.

\begin{tabular}{|c|c|c|}
\hline \multicolumn{3}{|c|}{ Contingência jurídica (destinadas ao responsável por uso de recursos) } \\
\hline EVENTO ANTECEDENTE & COMPORTAMENTO & CONSEQUENCIA \\
\hline $\begin{array}{l}\text { - Arrecadar, gerenciar, utilizar e } \\
\text { administrar os recursos públicos } \\
\text { ou valores pelos quais a União } \\
\text { responda. }\end{array}$ & $\begin{array}{l}\text { - omissão no dever de prestar } \\
\text { contas, } \\
\text { - não comprovação da } \\
\text { aplicação dos recursos } \\
\text { repassados pela União, na } \\
\text { forma prevista no inciso VII do } \\
\text { art. } 5^{\circ} \text { desta Lei (convênios, } \\
\text { acordos..) } \\
\text { - ocorrência de desfalque ou } \\
\text { desvio de dinheiros, bens ou } \\
\text { valores públicos } \\
\text { - prática de qualquer ato ilegal, } \\
\text { ilegítimo ou antieconômico de } \\
\text { que resulte dano ao erário. }\end{array}$ & $\begin{array}{l}\text { - contas julgadas irregulares } \\
\text { - débito (devolução dos valores } \\
\text { corrigidos) } \\
\text { - multa proporcional ao débito; } \\
\text { - multa sem débito; } \\
\text { - inabilitado, por um período que } \\
\text { variará de cinco a oito anos, para o } \\
\text { exercício de cargo em comissão ou } \\
\text { função de confiança no âmbito da } \\
\text { Administração Pública } \\
\text { - arresto dos bens dos responsáveis } \\
\text { julgados em débito. }\end{array}$ \\
\hline
\end{tabular}


Tabela 4.

Contingência jurídica no art. 19 e art. 57 da Lei $n^{\circ}$ 8.443/92 para os responsáveis de recursos públicos, autoridades administrativas e controle interno.

\section{Contingência jurídica (destinadas à autoridade administrativa)}

\begin{tabular}{|c|c|c|}
\hline EVENTO ANTECEDENTE & COMPORTAMENTO & CONSEQUENCIA \\
\hline $\begin{array}{l}\text { Tomar conhecimento de: } \\
\text { - omissão no dever de prestar } \\
\text { contas, } \\
\text { - não comprovação da aplicação } \\
\text { dos recursos repassados pela } \\
\text { União, na forma prevista no } \\
\text { inciso VII do art. } 5^{\circ} \text { desta Lei } \\
\text { (convênios, acordos, etc) } \\
\text { - ocorrência de desfalque ou } \\
\text { desvio de dinheiros, bens ou } \\
\text { valores públicos. } \\
\text { - prática de qualquer ato ilegal, } \\
\text { ilegítimo ou antieconômico de } \\
\text { que resulte dano ao erário }\end{array}$ & $\begin{array}{l}\text { - deixar de dar ciência de } \\
\text { imediato ao Tribunal de } \\
\text { Contas da União. }\end{array}$ & $\begin{array}{l}\text { - pagamento da dívida atualizada } \\
\text { monetariamente, acrescida dos juros } \\
\text { de mora devidos; } \\
\text { - multa prevista no art. } 57 \text { (multa de } \\
\text { até cem por cento do valor atualizado } \\
\text { do dano causado ao erário). } \\
\text { - inabilitado, por um período que } \\
\text { variará de cinco a oito anos, para o } \\
\text { exercício de cargo em comissão ou } \\
\text { função de confiança no âmbito da } \\
\text { Administração Pública } \\
\text { - arresto dos bens dos responsáveis } \\
\text { julgados em débito. } \\
\text { - Responsabilidade solidária. }\end{array}$ \\
\hline
\end{tabular}

Na Tabela 5 foi analisado o art. 51 e incisos 1 e 2 referente aos responsáveis pelo controle interno.

Art. 51. Os responsáveis pelo controle interno, ao tomarem conhecimento de qualquer irregularidade ou ilegalidade, dela darão ciência de imediato ao Tribunal de Contas da União, sob pena de responsabilidade solidária

$\S 1^{\circ} \mathrm{Na}$ comunicação ao Tribunal, o dirigente do órgão competente indicará as providências adotadas para evitar ocorrências semelhantes.

$\S 2^{\circ}$ Verificada em inspeção ou auditoria, ou no julgamento de contas, irregularidade ou ilegalidade que não tenha sido comunicada tempestivamente ao Tribunal, e provada a omissão, o dirigente do órgão de controle interno, na qualidade de responsável solidário, ficará sujeito às sanções previstas para a espécie nesta Lei.

Vale ressaltar que quando as contas são julgadas irregulares, porém não havendo débito, o Tribunal de Contas da União aplicará multa ao responsável (Parágrafo único e art. 58). 
Tabela 5.

Contingência jurídica no art. 51 da Lei $n^{\circ} 8.443 / 92$ e parágrafos 1 e 2 referente ao controle interno.

\begin{tabular}{|c|c|c|}
\hline \multicolumn{3}{|c|}{ Contingência jurídica (destinadas à autoridade ao responsável pelo controle interno) } \\
\hline $\begin{array}{c}\text { EVENTO } \\
\text { ANTECEDENTE }\end{array}$ & COMPORTAMENTO & CONSEQUENCIA \\
\hline $\begin{array}{l}\text { Tomar conhecimento de: } \\
\text { - omissão no dever de prestar } \\
\text { contas, } \\
\text { - não comprovação da } \\
\text { aplicação dos recursos } \\
\text { repassados pela União, na } \\
\text { forma prevista no inciso VII } \\
\text { do art. } 5^{\circ} \text { desta Lei } \\
\text { (convênios, acordos) } \\
\text { - ocorrência de desfalque ou } \\
\text { desvio de dinheiros, bens ou } \\
\text { valores públicos } \\
\text { - prática de qualquer ato } \\
\text { ilegal, ilegítimo ou } \\
\text { antieconômico de que resulte } \\
\text { dano ao erário }\end{array}$ & $\begin{array}{l}\text { - deixar de dar ciência de } \\
\text { imediato ao Tribunal de Contas } \\
\text { da União }\end{array}$ & $\begin{array}{l}\text {-responsabilidade } \\
\text { (contas julgadas irregulares; } \\
\text { débito (devolução dos valores } \\
\text { corrigidos); multa proporcional } \\
\text { ao débito; multa sem débito; } \\
\text { inabilitado, por um período que } \\
\text { variará de cinco a oito anos, para } \\
\text { o exercício de cargo em } \\
\text { comissão ou função de } \\
\text { confiança no âmbito da } \\
\text { Administração Pública; arresto } \\
\text { dos bens dos responsáveis } \\
\text { julgados em débito). }\end{array}$ \\
\hline
\end{tabular}

Parágrafo único. Não havendo débito, mas comprovada qualquer das ocorrências previstas nas alíneas $a, b$ e c do inciso III, do art. 16, o Tribunal aplicará ao responsável a multa prevista no inciso I do art. 58, desta lei.

Art. 58. O Tribunal poderá aplicar multa de Cr\$42.000.000,00 (quarenta e dois milhões de cruzeiros), ou valor equivalente em outra moeda que venha a ser adotada como moeda nacional, aos responsáveis por:

I - contas julgadas irregulares de que não resulte débito, nos termos do parágrafo único do art. 19 desta lei;

II - ato praticado com grave infração à norma legal ou regulamentar de natureza contábil, financeira, orçamentária, operacional e patrimonial;

III - ato de gestão ilegítimo ou antieconômico de que resulte injustificado dano ao erário;

IV - não atendimento, no prazo fixado, sem causa justificada, a diligência do Relator ou a decisão do Tribunal;

$V$ - obstrução ao livre exercício das inspeções e auditorias determinadas;

$V I$ - sonegação de processo, documento ou informação, em inspeções ou auditorias realizadas pelo Tribunal;

VII - reincidência no descumprimento de determinação do Tribunal.

$\S 1$ Ficará sujeito à multa prevista no caput deste artigo aquele que deixar de dar cumprimento à decisão do Tribunal, salvo motivo justificado. 
$\S 2^{\circ} O$ valor estabelecido no caput deste artigo será atualizado, periodicamente, por portaria da Presidência do Tribunal, com base na variação acumulada, no período, pelo índice utilizado para atualização dos créditos tributários da União.

$\S 3^{\circ} \mathrm{O}$ Regimento Interno disporá sobre a gradação da multa prevista no caput deste artigo, em função da gravidade da infração.

Como o valor da moeda estipulado pela Lei 8.443/92 está estabelecida em cruzeiros, anualmente o Tribunal de Contas da União tem atualizado o valor da multa em reais através de portarias.

- 2006 - Art. $1^{o}$ Fica fixado em $R \$ 30.523,17$ (trinta e dois mil, oitocentos e oitenta e cinco reais e sessenta e oito centavos), para o exercício de 2006, o valor máximo da multa a que se refere o art. 58, caput, da Lei $n^{\circ}$ 8.443, de 16 de julho de 1992.

- 2007 - Art. $1^{\circ}$ Fica fixado em $R \$ 31.481,60$ (trinta e dois mil, oitocentos e oitenta e cinco reais e sessenta e oito centavos), para o exercício de 2007, o valor máximo da multa a que se refere o art. 58, caput, da Lei $n^{\circ}$ 8.443, de 16 de julho de 1992.

- 2008 - Art. $1^{\circ}$ Fica fixado em $R \$ 32.885,68$ (trinta e dois mil, oitocentos e oitenta e cinco reais e sessenta e oito centavos), para o exercício de 2008, o valor máximo da multa a que se refere o art. 58, caput, da Lei $n^{\circ}$ 8.443, de 16 de julho de 1992.

- 2009 - Art. $1^{\circ}$ É fixado em $R \$ 34.825,94$ (trinta e quatro mil, oitocentos e vinte e cinco reais e noventa e quatro centavos), para o exercício de 2009, o valor máximo da multa a que se refere o art. 58, caput, da Lei $n^{\circ}$ 8.443, de 16 de julho de 1992.

- 2010 - Art. $1^{\circ}$ É fixado em $R \$ 36.814,50$ (trinta e seis mil, oitocentos e quatorze reais e cinquenta centavos), para o exercício de 2010, o valor máximo da multa a que se refere o art. 58, caput, da Lei $n^{\circ}$ 8.443, de 16 de julho de 1992.

- 2011 - Art. $1^{o}$ É fixado em $R \$ 38.993,92$ (quarenta e um mil quinhentos e vinte e oito reais e cinquenta e dois centavos), para o exercício de 2011, o valor máximo da multa a que se refere o art. 58, caput, da Lei $n^{\circ} 8.443$, de 16 de julho de 1992.

- 2012 - Art. $1^{\circ}$ É fixado em $R \$ 41.528,52$ (quarenta e um mil quinhentos e vinte e oito reais e cinquenta e dois centavos), para o exercício de 2012, o valor máximo da multa a que se refere o art. 58, caput, da Lei $n^{\circ}$ 8.443, de 16 de julho de 1992.

- 2013 - Art. $1^{\circ}$ É fixado em $R \$ 43.953,79$ (quarenta e três mil, novecentos e cinquenta e três reais e setenta e nove centavos), para o exercício de 2013, o valor máximo da multa a que se refere o art. 58, caput, da Lei $n^{\circ}$ 8.443, de 16 de julho de 1992.

- 2014 - Art. $1^{\circ}$ É fixado em $R \$ 46.551,46$ (quarenta e seis mil quinhentos e cinquenta e um reais e quarenta e seis centavos), para o exercício de 2014, o valor máximo da multa a que se refere o art. 58, caput, da Lei $n^{\circ}$ 8.443, de 16 de julho de 1992.

- 2015 - Art. $1^{\circ}$ É fixado em $R \$ 49.535,41$ (quarenta e nove mil, quinhentos e trinta e cinco 
reais e quarenta e um centavos), para o exercício de 2015, o valor máximo da multa a que se refere o art. 58, caput, da Lei $n^{\circ}$ 8.443, de 16 de julho de 1992.

- 2016 - Art. $1^{\circ}$ É fixado em $R \$ 54.820,84$ (cinquenta e quatro mil oitocentos e vinte reais e oitenta e quatro centavos), para o exercício de 2016, o valor máximo da multa a que se refere o art. 58, caput, da Lei $n^{\circ}$ 8.443, de 16 de julho de 1992.

Na Tabela 6 foi descrito a análise comportamental da contingência jurídicas destinadas ao responsável por uso de recurso público e autoridades administrativas, referente ao art. 58 .

Tabela 6.

Contingência jurídica no art. 58 da Lei $n^{\circ} 8.443 / 92$ e incisos 1 e 2 referente ao controle interno.

\section{Contingência Jurídica (destinadas ao responsável por uso de recursos)}

\section{EVENTO ANTECEDENTE COMPORTAMENTO \\ CONSEQUENCIA}

- Arrecadar, gerenciar, utilizar e administrar os recursos públicos ou valores pelos quais a União responda.
- ato praticado com grave infração à norma legal ou regulamentar de natureza contábil, financeira, orçamentária, operacional e patrimonial

- ato de gestão ilegítimo ou antieconômico de que resulte injustificado dano ao erário.
- contas julgadas irregulares sem debito - multa prevista no art. 58

Contingência Jurídica (destinadas à autoridade administrativa)

\section{EVENTO ANTECEDENTE}

- Ocorrência da irregularidade da gestão do recurso público.

\section{COMPORTAMENTO}

CONSEQUENCIA

-. obstrução ao livre exercício das inspeções e auditorias determinadas.

- sonegação de processo, documento ou informação, em inspeções ou auditorias realizadas pelo Tribunal.
- contas julgadas irregulares, sem débito.

- multa prevista no art. 58

Além das sanções envolvendo o ressarcimento do débito acrescido da multa no valor de até $100 \%$ do débito (art. 57) e multa sem débito (art. 58), outras sanções poderão ser aplicadas como a inabilitação em exercer cargo em comissão ou função de confiança em âmbito da Administração Pública conforme art. 60. 
Art. 60. Sem prejuízo das sanções previstas na seção anterior e das penalidades administrativas, aplicáveis pelas autoridades competentes, por irregularidades constatadas pelo Tribunal de Contas da União, sempre que este, por maioria absoluta de seus membros, considera grave a infração cometida, o responsável ficará inabilitado, por um período que variará de cinco a oito anos, para o exercício de cargo em comissão ou função de confiança no âmbito da Administração Pública.

Na Tabela 7 foi analisado o art. 60 descrevendo a contingência jurídica previstas na lei. Outra sanção envolvendo o julgamento irregular das TCE estão previstas no art. 61, que se refere a necessidade do arresto dos bens dos responsáveis julgados em débito descrita na Tabela 7.

Art. 61. O Tribunal poderá, por intermédio do Ministério Público, solicitar à Advocacia-Geral da União ou, conforme o caso, aos dirigentes das entidades que lhe sejam jurisdicionadas, as medidas necessárias ao arresto dos bens dos responsáveis julgados em débito, devendo ser ouvido quanto à liberação dos bens arrestados e sua restituição.

Tabela 7

Contingência jurídica no art. 60 da Lei $n^{\circ} 8.443 / 92$ e responsável pelo uso do recurso.

\section{Contingência jurídica (destinadas ao responsável por uso de recursos)}

\begin{tabular}{|c|c|c|}
\hline $\begin{array}{c}\text { EVENTO } \\
\text { ANTECEDENTE }\end{array}$ & COMPORTAMENTO & CONSEQUENCIA \\
\hline $\begin{array}{l}\text { - Arrecadar, gerenciar, } \\
\text { utilizar e administrar os } \\
\text { recursos públicos ou } \\
\text { valores pelos quais a } \\
\text { União responda. }\end{array}$ & $\begin{array}{l}\text { - omissão no dever de prestar contas, } \\
\text { - não comprovação da aplicação dos recursos } \\
\text { repassados pela União, na forma prevista no } \\
\text { inciso VII do art. } 5^{\circ} \text { desta Lei (convênios, } \\
\text { acordos) } \\
\text { - ocorrência de desfalque ou desvio de } \\
\text { dinheiros, bens ou valores públicos } \\
\text { - prática de qualquer ato ilegal, ilegítimo ou } \\
\text { antieconômico de que resulte dano ao erário }\end{array}$ & $\begin{array}{l}\text { - ficará inabilitado, por um } \\
\text { período que variará de } \\
\text { cinco a oito anos, para o } \\
\text { exercício de cargo em } \\
\text { comissão ou função de } \\
\text { confiança no âmbito da } \\
\text { Administração Pública. }\end{array}$ \\
\hline
\end{tabular}


Tabela 7

Contingência jurídica no art. 60 da Lei $n^{\circ} 8.443 / 92$ e responsável pelo uso do recurso.

\begin{tabular}{|c|c|c|}
\hline \multicolumn{3}{|c|}{ Contingência jurídica (destinadas ao responsável por uso de recursos) } \\
\hline $\begin{array}{l}\text { EVENTO ANTECEDENTE } \\
\text { - Arrecadar, gerenciar, utilizar e } \\
\text { administrar os recursos públicos ou } \\
\text { valores pelos quais a União } \\
\text { responda. }\end{array}$ & $\begin{array}{l}\text { COMPORTAMENTO } \\
\text { - omissão no dever de prestar } \\
\text { contas, } \\
\text { - não comprovação da } \\
\text { aplicação dos recursos } \\
\text { repassados pela União, na } \\
\text { forma prevista no inciso VII } \\
\text { do art. } 5^{\circ} \text { desta Lei } \\
\text { (convênios, acordos..) } \\
\text { - ocorrência de desfalque ou } \\
\text { desvio de dinheiros, bens ou } \\
\text { valores públicos } \\
\text { - prática de qualquer ato } \\
\text { ilegal, ilegítimo ou } \\
\text { antieconômico de que resulte } \\
\text { dano ao erário }\end{array}$ & $\begin{array}{l}\text { CONSEQUENCIA } \\
\text { - arresto dos bens dos } \\
\text { responsáveis julgados em } \\
\text { débito, devendo ser ouvido } \\
\text { quanto à liberação dos bens } \\
\text { arrestados e sua restituição. }\end{array}$ \\
\hline
\end{tabular}

\section{Regimento Interno do TCU}

O Tribunal de Contas da União é um órgão de controle externo, e de acordo com a Lei $\mathrm{n}^{\circ} 8.443$, de 16 de janeiro de 1992, tem como uma de suas funções julgar as contas de qualquer pessoa física ou jurídica, sendo esta pública ou privada, que utilize, arrecade, gerencie ou administre dinheiro advindos da União. Além da Lei Orgânica $n^{\circ} 8.443$, foi analisado o Regimento Interno do TCU, que complementou e detalhou a lei analisada anteriormente.

O art. 197 do Regimento Interno do TCU, complementa o art. 57 da Lei. 8.443 que prevê sanções para o comportamento na omissão no dever de prestar contas, conforme descrito abaixo e na Tabela 8 .

Art. 197. Diante da omissão no dever de prestar contas, da não-comprovação da aplicação dos recursos repassados pela União na forma prevista no inciso VIII do art. $5^{\circ}$, da ocorrência de desfalque 
ou desvio de dinheiros, bens ou valores públicos, ou, ainda, da prática de qualquer ato ilegal, ilegítimo ou antieconômico de que resulte dano ao erário, a autoridade administrativa competente, sob pena de responsabilidade solidária, deverá imediatamente adotar providências com vistas à instauração de tomada de contas especial para apuração dos fatos, identificação dos responsáveis e quantificação do dano.

Tabela 8.

Contingência jurídica no art. 197 do Regimento Interno do TCU, destinada à autoridade administrativa.

\begin{tabular}{|c|c|c|}
\hline \multicolumn{3}{|c|}{ Contingência jurídica (destinadas à autoridade administrativa) } \\
\hline $\begin{array}{c}\text { EVENTO } \\
\text { ANTECEDENTE }\end{array}$ & COMPORTAMENTO & CONSEQUENCIA \\
\hline $\begin{array}{l}\text { - Arrecadar, gerenciar, } \\
\text { utilizar e administrar os } \\
\text { recursos públicos ou } \\
\text { valores pelos quais a } \\
\text { União responda. }\end{array}$ & - omissão no dever de prestar contas & $\begin{array}{l}\text { - contas julgadas irregulares; } \\
\text { débito (devolução dos valores } \\
\text { corrigidos; multa proporcional } \\
\text { ao débito; multa sem débito; } \\
\text { inabilitado, por um período que } \\
\text { variará de cinco a oito anos, para } \\
\text { o exercício de cargo em } \\
\text { comissão ou função de } \\
\text { confiança no âmbito da } \\
\text { Administração Pública; arresto } \\
\text { dos bens dos responsáveis } \\
\text { julgados em débito) }\end{array}$ \\
\hline
\end{tabular}

Os artigos 210 e 267 do Regimento Interno são complementares ao art. 57 da Lei no 8.443/92. Uma vez que as contas são julgadas irregulares, o TCU pode aplicar uma multa de até $100 \%$ do valor do débito.

Art. 210. Quando julgar as contas irregulares, havendo débito, o Tribunal condenará o responsável ao pagamento da dívida, atualizada monetariamente a partir da data da irregularidade, acrescida dos juros de mora devidos, podendo, ainda, aplicar-lhe a multa prevista no art. 267. 
Art. 267. Quando o responsável for julgado em débito, poderá ainda o Tribunal aplicar-lhe multa de até cem por cento do valor atualizado do dano causado ao erário, conforme estabelecido no art. 57 da Lei $n^{\circ} 8.443$, de 1992.

Na Tabela 9 é descrito os artigos 210 e 267 nos quais prevê sanção uma vez que as contas são julgadas irregulares.

Tabela 9.

Contingência jurídica no art. 210 e 267 do Regimento Interno do TCU, ao responsável pelo uso do recurso.

\section{Contingência jurídica (destinadas ao responsável por uso de recursos)}

\section{EVENTO ANTECEDENTE COMPORTAMENTO}

- Arrecadar, gerenciar, utilizar e - dano ao erário administrar os recursos públicos ou valores pelos quais a União responda.

\section{CONSEQUENCIA}

- pagamento da dívida, atualizada monetariamente a partir da data da irregularidade, acrescida dos juros de mora.

- multa de até cem por cento do valor atualizado do dano causado ao erário, conforme estabelecido no art. 57 da Lei $\mathrm{n}^{\circ} 8.443$, de 1992.

O art. 214, inciso III refere-se as contas irregulares, definindo os prazos para a quitação do débito ou da multa.

Art. 214. A decisão definitiva publicada nos órgãos oficiais constituirá:

III - no caso de contas irregulares: a) obrigação de o responsável, no prazo de quinze dias, provar, perante o Tribunal, o pagamento da quantia correspondente ao débito que lhe tiver sido imputado ou da multa cominada; b) título executivo bastante para a cobrança judicial da dívida decorrente do débito ou da multa, se não recolhida no prazo pelo responsável; c) fundamento para que a autoridade competente proceda à efetivação da sanção e da medida cautelar previstas respectivamente nos art. 270 e 275 . 
Na Tabela 10 foi descrito o art. 214 identificando a norma e a contingência jurídica em utilizando a Análise Comportamental do Direito.

Tabela 10.

Contingência jurídica no art. 214 do Regimento Interno do TCU, ao responsável pelo uso do recurso.

\section{Contingência jurídica (destinadas ao responsável por uso de recursos)}

\section{EVENTO ANTECEDENTE COMPORTAMENTO CONSEQUENCIA}

- Arrecadar, gerenciar, utilizar e - dano ao erário - o pagamento da quantia correspondente ao débito que lhe tiver sido imputado ou da multa cominada ou valores pelos quais a União - cobrança judicial da dívida decorrente do débito ou da multa, se não recolhida no prazo pelo responsável;

O art. 219 do Regimento Interno complementa o inciso III do art. 214 descrito na Tabela 10. Esse artigo prevê desconto integral ou parcelado da dívida, podendo ser descontado diretamente dos proventos do responsável. Além disso, o TCU poderá autorizar a cobrança judicial por intermédio do Ministério Público. Além disso, o TCU poderá providenciar a inclusão do nome do responsável no Cadastro Informativo de créditos não quitados do setor público federal (CADIN).

Art. 219. Expirado o prazo a que se refere à alínea a do inciso III do art. 214, sem manifestação do responsável, o Tribunal:

I-determinará o desconto integral ou parcelado da dívida nos vencimentos, subsídio, salário ou proventos do responsável, observados os limites previstos na legislação pertinente;

II - autorizará, alternativamente, a cobrança judicial da dívida, por intermédio do Ministério Público junto ao Tribunal; 
III - providenciará a inclusão do nome do responsável no Cadastro Informativo de créditos não quitados do setor público federal - Cadin, na forma estabelecida em ato normativo. Parágrafo único. Caso o ressarcimento deva ser feito a estado ou município, o Tribunal remeter-lhes-á a documentação necessária à cobrança judicial da dívida.

Na Tabela 11 é descrito art. 219 da contingência jurídica, do Regimento Interno do TCU, ao responsável pelo uso do recurso público. Os eventos antecedentes a este artigo específico é a expiração do prazo do pagamento da dívida no inciso II do art. 214.

$\mathrm{O}$ art. 268 do Regimento Interno do TCU, complementa o art. 58 da Lei n⿳⺈.443/92 referente a sanção envolvendo multa quando não existe débito.

Art. 268. O Tribunal poderá aplicar multa, nos termos do caput do art. 58 da Lei $n^{\circ} 8.443$, de 1992, atualizada na forma prescrita no $\S 1^{o}$ deste artigo, aos responsáveis por contas e atos adiante indicados, observada a seguinte gradação:

Tabela 11.

Contingência jurídica no art. 219 do Regimento Interno do TCU, ao responsável pelo uso do recurso.

\section{Contingência jurídica (destinadas ao responsável por uso de recursos)}

$\begin{array}{ccc}\text { EVENTO } & \text { COMPORTAMENTO } & \text { CONSEQUENCIA } \\ \text { ANTECEDENTE } & \end{array}$

- Contas Julgadas - omissão no pagamento do - desconto integral ou parcelado da dívida irregulares, sendo débito, expirando o prazo do nos vencimentos, subsídio, salário ou apurado dano ao erário. pagamento da dívida do inciso proventos do responsável, observados os II do art. 214. limites previstos na legislação pertinente;

- cobrança judicial da dívida, por intermédio do Ministério Público junto ao Tribunal;

- inclusão do nome do responsável no Cadastro Informativo de créditos não quitados do setor público federal - Cadin, na forma estabelecida em ato normativo. 
I-contas julgadas irregulares, não havendo débito, mas comprovada qualquer das ocorrências previstas nos incisos I, II e III do caput do art. 209, no valor compreendido entre cinco e cem por cento do montante definido no caput deste artigo;

II - ato praticado com grave infração a norma legal ou regulamentar de natureza contábil, financeira, orçamentária, operacional ou patrimonial, no valor compreendido entre cinco e cem por cento do montante a que se refere o caput;

III - ato de gestão ilegítimo ou antieconômico de que resulte injustificado dano ao erário, no valor compreendido entre cinco e cem por cento do montante referido no caput;

IV - descumprimento, no prazo fixado, sem causa justificada, à diligência determinada pelo relator, no valor compreendido entre cinco e cinquenta por cento do montante a que se refere o caput; $V$ - obstrução ao livre exercício das auditorias e inspeções determinadas, no valor compreendido entre cinco e oitenta por cento do montante a que se refere o caput;

$V I$ - sonegação de processo, documento ou informação, em auditoria ou inspeção, no valor compreendido entre cinco e oitenta por cento do montante a que se refere o caput;

VII - descumprimento de decisão do Tribunal, salvo motivo justificado, no valor compreendido entre cinco e cinquenta por cento do montante a que se refere o caput;

VIII - reincidência no descumprimento de decisão do Tribunal, no valor compreendido entre cinquenta e cem por cento do montante a que se refere o caput. 
Tabela 12.

Contingência jurídica no art. 268 do Regimento Interno do TCU, ao responsável pelo uso do recurso.

Contingência jurídica (destinadas ao responsável por uso de recursos)

\begin{tabular}{|c|c|c|}
\hline $\begin{array}{c}\text { EVENTO } \\
\text { ANTECEDENTE }\end{array}$ & COMPORTAMENTO & CONSEQUENCIA \\
\hline $\begin{array}{l}\text { - Arrecadar, gerenciar, } \\
\text { utilizar e administrar os } \\
\text { recursos públicos ou } \\
\text { valores pelos quais a União } \\
\text { responda. }\end{array}$ & $\begin{array}{l}\text { - omissão no dever de prestar contas; } \\
\text { - prática de ato de gestão ilegal, } \\
\text { ilegítimo ou antieconômico, ou } \\
\text { infração a norma legal ou } \\
\text { regulamentar de natureza contábil, } \\
\text { financeira, orçamentária, operacional } \\
\text { ou patrimonial } \\
\text { - ato de gestão ilegítimo ou } \\
\text { antieconômico de que resulte } \\
\text { injustificado dano ao erário; }\end{array}$ & $\begin{array}{l}\text { - contas julgadas irregulares } \\
\text { porém sem débitos ao erário } \\
\text { - multa nos termos do caput do } \\
\text { art. } 58 \text { da Lei } \mathrm{n}^{\circ} 8.443 \text {, de } \\
1992 \text {. } \\
\text { - valor compreendido entre } \\
\text { cinco e cem por cento do } \\
\text { montante definido no caput } \\
\text { deste artigo. }\end{array}$ \\
\hline
\end{tabular}

Contingência jurídica (destinadas ao responsável por uso de recursos)

\section{EVENTO ANTECEDENTE \\ COMPORTAMENTO \\ CONSEQUENCIA}

Arrecadar, gerenciar, utilizar e administrar os recursos públicos ou valores pelos quais a União responda.
- ato praticado com grave infração a norma legal ou regulamentar de natureza contábil, financeira, orçamentária, operacional ou patrimonial.

- obstrução ao livre exercício das auditorias e inspeções determinadas.

- sonegação de processo, documento ou informação, em auditoria ou inspeção;
- contas julgadas irregulares sem débito ao erário.

- multa nos termos do caput do art. 58 da Lei $\mathrm{n}^{\circ}$ 8.443, de 1992.

- valor compreendido entre cinco e cem por cento do montante definido no caput deste artigo.
- Decisão do Tribunal de Contas da União referente ao processo de tomada de contas especial.
- descumprimento de decisão do Tribunal, salvo motivo justificado; - reincidência no descumprimento de decisão do Tribunal.
- multa nos termos do caput do art. 58 da Lei no 8.443, de 1992. - valor compreendido entre cinco e cem por cento do montante definido no caput deste artigo. 
O art. 270 do Regimento Interno prevê outra sanção além das multas, uma vez que seja considerada grave a infração cometida por maioria absoluta de seus membros. Trata-se da inabilitação para exercer cargo em comissão ou função do confiança no âmbito da administração pública federal, podendo ser de 5 a 8 anos. Entretanto o art. 270 não descreve quais atos podem ser considerados infração grave.

Art. 270. Sem prejuízo das sanções previstas nos art.. 267 e 268 e das penalidades administrativas aplicáveis pelas autoridades competentes, por irregularidades constatadas pelo Tribunal, sempre que este, por maioria absoluta de seus membros, considerar grave a infração cometida, o responsável ficará inabilitado, por um período que variará de cinco a oito anos, para o exercício de cargo em comissão ou função de confiança no âmbito da administração pública federal, nos termos do art. 60 da Lei $n^{\circ} 8.443$, de 1992.

Na Tabela 13 é descrito a contingência jurídica no art. 210 do Regimento Interno do TCU.

Tabela 13.

Contingência jurídica no art. 270 do Regimento Interno do TCU, ao responsável pelo uso do recurso.

\section{Contingência jurídica (destinadas ao responsável por uso de recursos)}

EVENTO ANTECEDENTE COMPORTAMENTO CONSEQUENCIA

- Arrecadar, gerenciar, utilizar - grave infração cometida (atos e administrar os recursos graves não são especificados no públicos ou valores pelos quais artigo em questão). a União responda.
- o responsável ficará inabilitado, por um período que variará de cinco a oito anos, para o exercício de cargo em comissão ou função de confiança no âmbito da administração pública federal, nos termos do art. 60 da Lei $\mathrm{n}^{\circ}$ 8.443, de 1992. 
No art. 271 refere-se à inidoneidade do licitante fraudador, uma vez que a fraude seja comprovada na licitação, poderá ficar até 5 anos sem participar de licitações envolvendo administração pública federal.

Art. 271. Verificada a ocorrência de fraude comprovada a licitação, o Plenário declarará a inidoneidade do licitante fraudador para participar, por até cinco anos, de licitação na administração pública federal, nos termos do art. 46 da Lei $n^{\circ} 8.443$, de 1992

Na Tabela 14 é descrito a contingência jurídica no art. 271 do Regimento Interno do TCU.

Tabela 14

Contingência jurídica no art. 271 do Regimento Interno do TCU, ao responsável pelo uso do recurso.

Contingência jurídica (destinadas ao responsável por uso de recursos)

\begin{tabular}{lll}
\hline EVENTO & COMPORTAMENTO & \multicolumn{1}{c}{ CONSEQUENCIA } \\
ANTECEDENTE & & \\
- Arrecadar, gerenciar, & - fraude na licitação & - a inidoneidade do licitante \\
utilizar e administrar os & & $\begin{array}{l}\text { fraudador para participar, por até } \\
\text { cinco anos, de licitação na }\end{array}$ \\
recursos públicos ou & & $\begin{array}{l}\text { administração pública federal, } \\
\text { nalores pelos quais a }\end{array}$ \\
União responda. & 8.443, de 1992.
\end{tabular}

\section{Discussão}

Um dos objetivos do Estudo 1 foi descrever a rede jurídica que envolve a tomada de contas especial, bem como adotar a Análise Comportamental do Direito para analisar contingências aninhadas, ou seja, as normas jurídicas e as contingências jurídicas.

A rede jurídica relacionada a Tomada de Conta Especial (TCE) foi descrita e essa envolve o Tribunal de Contas da União (TCU) que instaura e julga as TCE. O Ministério da 
Transparência, Fiscalização e Controladoria-Geral da União é responsável pela fiscalização de recursos advindos da União, podendo instaurar TCE, além de analisar os processos de TCE antes do envio para julgamento no TCU. Os ministérios são responsáveis pela fiscalização e instalação das TCE referentes aos convênios firmados com os estados e municípios, bem como, irregularidades do próprio ministério. E por último, o Ministério Público (MP), uma vez que o TCU pode solicitar ao MP a cobrança da dívida com a União.

A rede de relações estabelecidas interage a fim de fiscalizar, controlar e sancionar o comportamento dos gestores dos recursos públicos com o intuito de alcançar as metas sociais relacionadas às normas jurídicas. Essa análise se torna possível, partindo do princípio que o Direito pode ser compreendido como um sistema de contingências sociais do direito, que geralmente ressalta o controle punitivo dos comportamentos que são considerados socialmente indesejáveis (cf. Aguiar, 2006). Esse sistema de contingências sociais pode ser compreendido como a própria norma jurídica, pois de acordo com Aguiar (2006), contingências sociais são funcionalmente especializadas no controle punitivo de comportamentos considerados socialmente indesejáveis, dentro do contexto da Análise Comportamental do Direito, isto seria sinônimo de norma.

A norma jurídica incluiria as premissas comportamentais, as contingências jurídicas [comportamentos indesejáveis (comportamento alvo a ser modificado) que sofreriam as sanções (punições previsto na lei) ] e a meta social. A norma inclui a sanção, e essa pode ou não funcionar como punição (no sentido técnico, que significa que a consequência irá reduzir a frequência do comportamento) ou como estímulo aversivo condicionado (no sentido técnico, de que o estímulo induz novos comportamentos negativamente reforçados pela cessação/diminuição da probabilidade de ocorrência do estímulo aversivo em questão). (e.g., Skinner, 1953; Baum, 1995 e 2005). As normas jurídicas fazem parte de uma estrutura maior 
jurídica, que inclui um componente político-valorativo (a meta social) e um científicodescritivo (as premissas comportamentais) (e.g., Aguiar, 2013 e 2014).

Algumas contingências descrevem a relação funcional do comportamento e suas consequências, nesse caso específico, a relação entre uma conduta delituosa e um correspondente reforço [por exemplo, desfalque ou desvio de dinheiro público (comportamento) e possuir mais dinheiro (reforço positivo)]. Entretanto, uma nova relação funcional também poderia ser estabelecida: a contingência entre as consequências da conduta delituosa (desfalque ou desvio de dinheiro público) e o bem-estar da sociedade (ou seja, o efeito aversivo do desfalque ou desvio de dinheiro público para terceiros), por exemplo, obras não concluídas, falta de recursos na saúde, etc.

A contingência entre o descontentamento da sociedade com o decréscimo de bem-estar e a sobrevivência política de autoridades eletivas (Executivo e Legislativo) acabam por estabelecer uma rede de relações jurídicas, com o intuito de coibir tal tipo de comportamento delituoso. As sanções previstas na lei só fazem sentido de serem estabelecidas e posteriormente aplicadas, se tal comportamento delituoso ocorre com uma frequência elevada, sendo necessário puni-lo. A norma visa então o alcance de metas sociais, nesse caso, gerar benefícios à sociedade coibindo os comportamentos delituosos de indivíduos (nesse estudo gestores de recursos públicos), envolvendo ainda um componente político-valorativo para a rede jurídica.

Como dito anteriormente, na proposta da Análise Comportamental do Direito, compreender a rede jurídica é importante, tendo em vista que essa rede é responsável pela aplicação das sanções e, consequentemente, pelo alcance das metas sociais. Porém a descrição não é suficiente para saber se as metas sociais seriam ou não alcançadas, mas somente para saber a relação entre os diferentes órgãos. 
No Estudo 1 foi aplicado o modelo proposto por Aguiar (2013) para a análise comportamental da Lei 8.443/92 e do Regimento Interno do TCU, referente a Tomada de Conta Especial. O modelo foi aplicado na descrição, logo, foi descrito a norma jurídica (premissas, sanção e meta social) e, aninhadas a elas, foram descritas as contingências jurídicas (eventos antecedentes, comportamento e consequências).

O modelo da Análise Comportamental do Direito pode ser utilizado como uma ferramenta descritiva de normas e contingências jurídicas. A análise com base nesse modelo pode ser útil de diversas formas, como, por exemplo, pode facilitar a identificação de incompletudes nas contingências jurídicas, quando um dos elementos não é definido ou é definido ambiguamente. Por exemplo, no art. 270 do Regimento Interno do TCU, é prevista aplicação da sanção de inabilitação por 5 a 8 anos para exercer cargo em comissão ou função do confiança no âmbito da administração pública federal ao gestor do recurso público, uma vez que seja considerada grave a infração cometida por maioria absoluta de membros do plenário do TCU. Entretanto o art. 270 não descreve quais atos, ou características dos atos que devem ser considerados como infração grave.

Esse tipo de análise de contingências jurídicas, ao explicitar as contingências previstas ou concebidas pelo legislador, pode facilitar a comparação entre o que foi planejado e o que ocorreu de fato. Por isso, a partir das descrições realizadas no Estudo 1 selecionaram-se algumas variáveis a serem analisadas no Estudo 2, com o objetivo de identificar alguns aspectos das contingências vigentes no que se referem aos comportamentos de gestores de recursos públicos.

\section{Estudo 2}

Uma contingência estabelece uma relação de dependência entre eventos comportamentais e ambientais (e.g., Catania, 1999; Skinner, 1953/2006, 1969). Para Skinner (1969) o arranjo de contingências de reforçamento e seu bom planejamento proporcionam tanto 
a manutenção como a mudança de comportamentos, se compreendermos as contingências de reforço que mantêm um determinado comportamento, poderemos então interpretá-lo com mais sucesso. Poder-se-ia concluir que o alcance de metas sociais poderia ser resultado de arranjo de contingências em nossos ambientes (cf. Glenn, 1986; 1989).

Porém, é preciso considerar que o planejamento de contingências não significa necessariamente que as contingências estão vigentes. Por exemplo, a Lei de Responsabilidade Fiscal prevê a transparência no que se refere a arrecadação de tributos e controle de gastos federais, dos estados e municípios. Machado e Costa (2008) afirmam que a Lei de Responsabilidade Fiscal estabelece normas para um comportamento ético do gestor no trato do patrimônio público que lhe foi imputado. Nesse caso, poderíamos considerar a lei como uma contingência que foi prevista para os gestores públicos. Entretanto, quando um governo gasta mais do que o previsto no orçamento anual, é possível dizer que outras contingências vigentes exerceram controle sobre tais gastos.

Essa discrepância entre o previsto e as contingências vigentes foi exemplificado por Aguiar (2013):

[...] se um membro menor de idade de uma quadrilha de bandidos armados declara a um órgão de imprensa que "De menor tem mesmo que roubar porque não dá nada. O máximo que ele fica preso é 45 dias" e tal enunciado corresponde, com um grau razoável de aproximação, a uma regra jurídica formal em vigor; então, do ponto de vista de uma análise funcional behaviorista, a regra formal e o enunciado informal do criminoso, são descrições verbais da mesma contingência jurídica. $O$ problema se complica quando, ao menos aparentemente, a regra formal não corresponde à contingência efetiva descrita pelo enunciado informal (p. 184) 
Se as contingências previstas forem diferentes das contingências vigentes, as contingências vigentes irão estabelecer e manter o padrão de comportamento em questão. Vários estudos investigaram os efeitos do controle por regras e do controle por contingências sob o comportamento humano (e.g., Shimoff, Catania \& Matthews, 1981; Hayes, Gifford \& Hayes, 1998; Hayes, Barnes-Holmes \& Roche, 2000 e Hayes, Zettle, \& Rosenfarb, 1989). Quando existe correspondência entre as regras (descrição da contingência previstas) e as contingências vigentes, o comportamento de seguir aquela regra se mantém (e.g., Galizio, 1979; Joyce \& Chase, 1990; Torgrud \& Holborn, 1990). Porém, quando ocorre discrepância as vezes o comportamento tende a ficar sobre o controle da contingência vigente e não da regra (cf. Albuquerque \& Silva, 2012).

No Estudo 1 as contingências previstas na Lei $n^{\circ}$ 8.443/92 e no Regimento Interno do TCU foram analisadas e descritas. Essa análise teve por objetivo identificar as contingências previstas, no sentido de relações previstas na lei referente ao comportamento de prestação de contas. Porém, o planejamento de uma contingência não garante que ela seja implementada, ou seja, as consequências nela previstas podem não ocorrer por falhas em componentes da rede jurídica (e.g., não há detecção dos atos indesejáveis, não há processo adequado de investigação, processo jurídico pode ser ineficiente, etc.).

No Estudo 2 buscou-se identificar e descrever alguns aspectos das contingências vigentes nos processos de prestação de contas dos gestores públicos, analisando a lista que o TCU envia ao TSE a cada dois anos (baseado na lei da ficha limpa) com o nome dos responsáveis (pessoas físicas) que tiveram suas contas julgadas irregulares pelo TCU. Foram descritas algumas das características gerais de variáveis afetas aos processos (e.g. identificar o valor médio das multas aplicadas) e exploradas algumas possíveis relações entre tais 
características (e.g., verificar se o valor da multa varia de acordo com o valor do dano causado) que possibilitariam identificar alguns aspectos das contingências vigentes.

\section{Método}

O Tribunal de Contas da União gera uma lista com a relação de responsáveis com contas julgadas irregulares durante os oito anos que precedem a eleição. Essa lista é encaminha ao Tribunal Superior Eleitoral (TSE) a cada dois anos com base na Lei 9.504/1997 (Lei Eleitoral) e na Lei Complementar 135/2010 (Lei da Ficha Limpa). Nesse estudo, utilizou-se a lista remetida ao TSE em 2014 com 10.512 nomes.

Essa lista possui um link para o site do TCU com acesso aos acórdãos dos processos. Os acórdãos contêm a decisão das TCE proferidas pelo Plenário ou pela $1^{\mathrm{a}}$ ou $2^{\mathrm{a}}$ Câmaras. Eventualmente, a TCE pode ter só um acórdão, mas isso nem sempre ocorre, por haver recursos ou diferenças nos votos dos juízes. Estes foram analisados, identificando valor do débito, valor da multa com a fundamentação legal de sua aplicação (art. 57 e/ou 58 da Lei 8.443/92), o órgão que instaurou a TCE, os cargos dos responsáveis na TCE, se houve recurso, se envolviam convênios, a duração do processo, se a sanção de inabilitação para o exercício de função pública foi aplicada, motivo de instauração baseado no art. 16, inciso III, alíneas "a", "b", "c" e "d", e mesmo se ocorreu combinações entre as alíneas (e.g., "ab", "acd", "abcd” etc).

Quando alguma informação não era identificada no acórdão, isso foi rotulado como missing. Alguns processos estavam classificados como sigilosos, nesses casos, o acesso à maioria das informações eram restritas e foram classificadas as informações disponíveis e colocada como missing as demais.

Como variáveis dependentes, foram selecionadas as possíveis sanções aplicadas pelo TCU quando as contas são julgadas irregulares. 
1) Valor da multa aplicada com base no art. 57 da Lei 8.443, a qual pode ser aplicada ao responsável quando for julgado em débito. Nesse caso, o Tribunal de Contas pode aplicar uma multa de até cem por cento do valor atualizado do dano causado ao erário.

2) Porcentagem do valor da multa prevista no art. 57 com relação ao valor do débito identificado no processo (e.g., porcentagem sobre o montante do débito).

3) Multa do art. 58 da Lei $n^{\circ} 8.443$ pode ser aplicada aos responsáveis quando suas contas forem julgadas irregulares, porém que não resulte em débito ao erário. Essa multa varia de 5\% a 95\% de um valor anualmente definido pelo Tribunal de Contas da União.

4) Sanção de Inabilitação do art. 60 da Lei $n^{\circ}$ 8443, que prevê que sem prejuízo das sanções descritas anteriormente, e se por maioria absoluta de seus membros, considerar grave a infração cometida, o responsável ficará inabilitado, por um período que variará de cinco a oito anos, para o exercício de cargo em comissão ou função de confiança no âmbito da Administração Pública.

Foram selecionadas duas amostras aleatórias e representativas (371 nomes em cada amostra) da planilha de 10.572 condenados pelo TCU no julgamento de contas irregulares. Na seleção da segunda amostra, quando saia o número do processo igual ao da primeira, foi selecionado o processo subsequente. Se este também estivesse na amostra 1, então foi selecionado o antecessor. Estimou-se um nível de confiança de $95 \%$ e erro amostral de 5\%. As duas amostras aleatórias foram analisadas nos mesmos termos para garantir a fidedignidade. Para tanto, foi feito um cálculo conforme a fórmula abaixo:

$$
n=\frac{N \cdot Z^{2} \cdot p \cdot(1-p)}{Z^{2} \cdot p \cdot(1-p)+e^{2} \cdot(N-1)}
$$

Onde:

n - amostra calculada; $\mathrm{N}$ - população; Z - variável normal padronizada associada ao nível de confiança; $\mathrm{p}$ - verdadeira probabilidade do evento; e - erro amostral 
A análise dos dados do Estudo 2 foi dividida em duas partes:, na primeira análise, foram descritas características gerais dos processos, com base em estatísticas descritivas. E, na segunda análise, foram exploradas as relações entre variáveis, com base nas contingências identificadas no Estudo 1.

\section{Resultados}

Os dados foram analisados utilizando o software IBM SPSS (20), dividida em duas partes: (1) análises descritivas para se identificar as características gerais dos processos, como duração do processo, número de responsáveis, montantes analisados e débitos, atos cometidos, quantidade de recursos, cargo do responsável, valores das multas, porcentagem das multas, estado da federação, instauração do processo, convênios, sigilo e sanção de inabilitação; e (2) análises de regressão linear para identificar potenciais variáveis preditoras das sanções aplicadas pelo Tribunal de Contas da União (multa - art. 57 e 58, porcentagem da multa do art. 57 e sanção de inabilitação). Algumas variáveis só puderam ser analisadas como variáveis binárias (e.g., Processo Instaurado pelo TCU - Sim ou Não).

\section{Análises Descritivas}

A Tabela 15 apresenta a frequência absoluta e a porcentagem referente aos motivos de instauração da Amostra 1, descritas com. base art. 16, inciso III, alínea "a", "b", "c" ou "d". Pode ocorrer do processo ser insaturado pela combinação de duas ou mais alíneas, por exemplo, alínea "ab", "ac", "bc”, "bd", “abc", "abd” etc. A alínea "c" (dano ao erário decorrente de ato de gestão ilegítimo ao antieconômico) apresenta a maior porcentagem dos motivos de instauração, 28,6\%, e a línea "b" (prática de ato de gestão ilegal) logo atrás com 15,6\%. A combinação de dois atos com maior porcentagem é a prática de ato de gestão ilegal e dano ao erário (alínea "a" e "c") que foi de 14,0\%, as demais combinações ocorrem com porcentagem entre $3 \%$ a $0,3 \%$. As porcentagens foram calculadas considerando a amostra total $(\mathrm{N}=371)$. 


\section{Tabela 15}

Frequências absolutas e porcentagem referente aos motivos da instauração da TCE na Amostra 1.

\begin{tabular}{|c|c|c|}
\hline Motivo da Instauração da TCE & $\begin{array}{l}\text { Frequência } \\
\text { Absoluta }\end{array}$ & $\begin{array}{l}\text { Porcentagem } \\
\qquad(\%)\end{array}$ \\
\hline Missing & 8 & 2,2 \\
\hline Omissão no dever de prestar contas (alínea "a") & 44 & 11,9 \\
\hline $\begin{array}{l}\text { Prática de ato de gestão ilegal, ilegítimo, antieconômico, ou } \\
\text { infração à norma legal ou regulamentar de natureza contábil, } \\
\text { financeira, orçamentária, operacional ou patrimonial (alínea "b") }\end{array}$ & 58 & 15,6 \\
\hline $\begin{array}{l}\text { Dano ao erário decorrente de ato de gestão ilegítimo ao } \\
\text { antieconômico (alínea "c") }\end{array}$ & 106 & 28,6 \\
\hline $\begin{array}{l}\text { Desfalque ou desvio de dinheiros, bens ou valores públicos } \\
\text { (alínea "d") }\end{array}$ & 49 & 13,2 \\
\hline $\begin{array}{l}\text { Omissão no dever de prestar contas e dano ao erário } \\
\text { (alínea "a" e "c") }\end{array}$ & 15 & 4,0 \\
\hline $\begin{array}{l}\text { Omissão no dever de prestar contas e Desfalque ou desvio de } \\
\text { dinheiro (alínea "a" e "d") }\end{array}$ & 1 & 0,3 \\
\hline Prática de ato de gestão ilegal e Dano ao erário (alínea "b" e "c") & 51 & 14,0 \\
\hline $\begin{array}{l}\text { Prática de ato de gestão ilegal e Desfalque ou desvio de dinheiro } \\
\text { (alínea "b" e "d") }\end{array}$ & 11 & 3,0 \\
\hline Dano ao erário e Desfalque ou desvio (alínea "c" e "d") & 12 & 3,2 \\
\hline $\begin{array}{l}\text { Omissão no dever de prestar contas, Prática de ato de gestão } \\
\text { ilegal e Dano ao erário (alínea "a", "b" e "c") }\end{array}$ & 1 & 0,3 \\
\hline $\begin{array}{l}\text { Omissão no dever de prestar contas, Dano ao erário e Desfalque } \\
\text { ou desvio de dinheiro (alínea "a", "c" e "d") }\end{array}$ & 1 & 0,3 \\
\hline $\begin{array}{l}\text { Prática de ato de gestão ilegal, Dano ao erário e Desfalque ou } \\
\text { desvio de dinheiro (alínea "b", "c" e "d") }\end{array}$ & 6 & 1,6 \\
\hline $\begin{array}{l}\text { Omissão no dever de presta contas, Prática de ato de gestão } \\
\text { ilegal, Dano ao erário e Desfalque ou desvio de dinheiro (alínea } \\
\text { "a", "b", "c" e "d") }\end{array}$ & 1 & 0,3 \\
\hline Total & 371 & 100 \\
\hline
\end{tabular}


Na Tabela 16 foi descrita a frequência absoluta e porcentagem dos motivos de instauração da Amostra 2. A mesma tendência foi observada, ou seja, a porcentagem da alínea "c" foi de 25,3\%, seguida pela alínea "b" com 19,9\%. Na combinação de motivos de instauração, a alínea "b" e "c" também apresentam a maior porcentagem, 14,3\%.

Tabela 16

Frequências absolutas e porcentagem referente aos motivos da instauração da TCE na Amostra 2

\begin{tabular}{lcc}
\hline Motivo da Instauração da TCE & $\begin{array}{c}\text { Frequência } \\
\text { Absoluta }\end{array}$ & $\begin{array}{c}\text { Porcentagem } \\
(\%)\end{array}$ \\
\hline Missing & 6 & 1,6 \\
Omissão no dever de prestar contas (alínea "a") & 42 & 11,3 \\
Prática de ato de gestão ilegal, ilegítimo, antieconômico, ou infração & & 19,9 \\
à norma legal ou regulamentar de natureza contábil, financeira, & 74 & \\
orçamentária, operacional ou patrimonial (alínea "b") & & 25,3 \\
Dano ao erário decorrente de ato de gestão ilegítimo ao & 94 & 9,7 \\
antieconômico (alínea "c") & 36 & 1,6 \\
Desfalque ou desvio de dinheiros, bens ou valores públicos (alínea \\
"d")
\end{tabular}


Tabela 16

Frequências absolutas e porcentagem referente aos motivos da instauração da TCE na Amostra 2

\begin{tabular}{lcc}
\hline Motivo da Instauração da TCE & $\begin{array}{c}\text { Frequência } \\
\text { Absoluta }\end{array}$ & $\begin{array}{c}\text { Porcentagem } \\
(\%)\end{array}$ \\
\hline $\begin{array}{l}\text { Prática de ato de gestão ilegal, Dano ao erário e Desfalque ou desvio } \\
\text { de dinheiro (alínea b, c e d) }\end{array}$ & 5 & 1,3 \\
$\begin{array}{l}\text { Omissão no dever de presta contas, Prática de ato de gestão ilegal, } \\
\text { Dano ao erário e Desfalque ou desvio de dinheiro (alínea a, b, c e d) }\end{array}$ & 1 & 0,3 \\
\hline Total & 371 & 100 \\
\hline
\end{tabular}

A Tabela 17 apresenta as frequências absolutas e a porcentagem em relação à instauração pelo TCU, débito solidário, convênio, processo sigiloso na Amostra 1 e 2, sendo o $\mathrm{N}=371$. A maior parte das TCE não são instauradas pelo TCU, 92,2\% na Amostra 1 e 94,3\% na Amostra 2. É possível perceber que as duas amostras seguem a mesma tendência nos resultados descritos abaixo.

Tabela 17.

Frequência absoluta e porcentagem em relação a instauração pelo TCU, débito solidário, convênio, processo em sigilo na Amostra 1 e 2.

\begin{tabular}{lcccc}
\hline & \multicolumn{2}{c}{$1^{\mathbf{0}}$ Amostra } & \multicolumn{2}{c}{$2^{\mathbf{0}}$ Amostra } \\
\cline { 2 - 5 } & $\begin{array}{c}\text { Frequência } \\
\text { Absoluta }\end{array}$ & $\begin{array}{c}\text { Porcentagem } \\
(\%)\end{array}$ & $\begin{array}{c}\text { Frequência } \\
\text { Absoluta }\end{array}$ & Porcentagem (\%) \\
\hline Instaurado pelo TCU & 29 & 7,8 & 20 & 5,4 \\
Sim & 342 & 92,2 & 350 & 94,3 \\
Não & 0 & 0 & 1 & 0,3 \\
Missing & 371 & 100 & 371 & 100 \\
Total & 265 & 71,4 & 262 & 70,6 \\
\hline Débito Solidário & 103 & 27,8 & 109 & 29,4 \\
Sim & 3 & 0,8 & 0 & 0 \\
Não & 371 & 100 & 371 & 100 \\
Missing & & & & \\
Total & & & & \\
\hline
\end{tabular}


Tabela 17.

Frequência absoluta e porcentagem em relação a instauração pelo TCU, débito solidário, convênio, processo em sigilo na Amostra 1 e 2.

\begin{tabular}{lcccc}
\hline Convênio & 219 & 59,0 & 241 & 65 \\
Sim & 149 & 40,2 & 125 & 33,7 \\
Não & 3 & 0,8 & 5 & 1,3 \\
Missing & 371 & 100 & 371 & 100 \\
Total & 9 & & & \\
\hline Processo em Sigilo & 361 & 2,4 & 7 & 1,9 \\
Sim & 0 & 07,6 & 364 & 91,1 \\
Não & 371 & 100 & 0 & 0 \\
Missing & & & 371 & 100 \\
Total & & & & \\
\hline
\end{tabular}

Na Tabela 18 foram descritos os cargos ou funções dos responsáveis das TCE em suas frequências absolutas e porcentagem. Os cargos que apareceram com 0,3\% foram agrupados na categoria 'outros'. Das 10 categorias descritas, 'Prefeito' é o cargo com a maior porcentagem nas TCE, $44,7 \%$ e $41,2 \%$ respectivamente das amostras analisadas.

Tabela 18

Frequência absoluta e porcentagem do cargo ou função do responsável das TCE na Amostra $1 e 2$.

\begin{tabular}{lcccc}
\hline \multirow{2}{*}{ Cargo ou Função do responsável } & \multicolumn{2}{c}{ Amostra 1 } & \multicolumn{2}{c}{ Amostra 2 } \\
\cline { 2 - 5 } & Frequência & Porcentagem & Frequência & Porcentagem \\
& Absoluta & $(\%)$ & Absoluta & $(\%)$ \\
\hline Missing & 52 & 14,0 & 49 & 13,2 \\
Beneficiário de Fraude & 1 &, 3 & 0 & 0 \\
Bolsista CNPQ ou CAPES & 7 & 1,9 & 12 & 3,2 \\
Funcionário & 7 & 1,9 & 8 & 2,2 \\
Gerente, Chefe ou Coordenador & 23 & 6,2 & 34 & 9,2 \\
Membro da Comissão de Licitação & 12 & 3,2 & 20 & 5,4 \\
ou Fiscalização & 13 & 3,5 & 16 & 4,3 \\
Outros & & & & 83 \\
\hline
\end{tabular}


Tabela 18.

Frequência absoluta e porcentagem do cargo ou função do responsável das TCE na Amostra 1 $e 2$.

\begin{tabular}{lcccc}
\hline Prefeito & 166 & 44,7 & 153 & 41,2 \\
Presidente ou Diretor & 39 & 10,5 & 47 & 12,7 \\
Secretário Estadual & 5 & 1,3 & 6 & 1,6 \\
Secretário Municipal & 14 & 3,8 & 9 & 2,4 \\
Servidor & 25 & 6,7 & 13 & 3,5 \\
Tesoureiro ou Contador & 7 & 1,9 & 4 & 1,1 \\
\hline Total & 371 & 100 & 371 & 100 \\
\hline
\end{tabular}

A quantidade de processos de tomada de contas especial por unidade federativa foi analisada e descrita na Tabela 19 (frequência absoluta e porcentagem). As maiores incidências de processos ocorreram no estado do Maranhão, seguidas por São Paulo, Minas Gerais, Rio de Janeiro e Paraná.

Tabela 19.

Frequência absoluta e porcentagem das TCE por unidade federativa na Amostra 1 e 2.

\begin{tabular}{lcccc}
\hline \multirow{2}{*}{ Estado do Processo } & \multicolumn{2}{c}{$\mathbf{1}^{\mathbf{0}}$ Amostra } & \multicolumn{2}{c}{$2^{\mathbf{0}}$ Amostra } \\
\cline { 2 - 5 } & $\begin{array}{c}\text { Frequência } \\
\text { Absoluta }\end{array}$ & $\begin{array}{c}\text { Porcentagem } \\
(\%)\end{array}$ & $\begin{array}{c}\text { Frequência } \\
\text { Absoluta }\end{array}$ & $\begin{array}{c}\text { Porcentage } \\
\text { m (\%) }\end{array}$ \\
\hline Missing & 2 &, 5 & 1 &, 3 \\
Acre (AC) & 5 & 1,3 & 6 & 1,6 \\
Alagoas (AL) & 12 & 3,2 & 7 & 1,9 \\
Amazonas (AM) & 19 & 5,1 & 12 & 3,2 \\
Amapá (AP) & 8 & 2,2 & 9 & 2,4 \\
Bahia (BA) & 18 & 4,9 & 22 & 5,9 \\
Ceará (CE) & 13 & 3,5 & 13 & 3,5 \\
Distrito Federal (DF) & 12 & 3,2 & 15 & 4,0 \\
Espírito Santo (ES) & 7 & 1,9 & 11 & 3,0 \\
Goiás (GO) & 6 & 1,6 & 9 & 2,4 \\
Maranhão (MA) & 44 & 11,9 & 42 & 11,3 \\
Minas Gerais (MG) & 23 & 6,2 & 24 & 6,5 \\
Mato Grosso do Sul (MS) & 8 & 2,2 & 16 & 4,3 \\
\hline
\end{tabular}


Tabela 19.

Frequência absoluta e porcentagem das TCE por unidade federativa na Amostra 1 e 2.

\begin{tabular}{lcccc}
\hline Mato Grosso (MT) & 13 & 3,5 & 10 & 2,7 \\
Pará (PA) & 21 & 5,7 & 18 & 4,9 \\
Paraíba (PB) & 14 & 3,8 & 9 & 2,4 \\
Pernambuco (PE) & 20 & 5,4 & 21 & 5,7 \\
Piauí (PI) & 6 & 1,6 & 10 & 2,7 \\
Paraná (PR) & 21 & 5,7 & 19 & 5,1 \\
Rio de janeiro (RJ) & 21 & 5,7 & 26 & 7,0 \\
Rio Grande do Norte (RN) & 11 & 3,0 & 7 & 1,9 \\
Rondônia (RO) & 7 & 1,9 & 8 & 2,2 \\
Roraima (RR) & 3 &, 8 & 8 & 2,2 \\
Rio Grande do Sul (RS) & 5 & 1,3 & 4 & 1,1 \\
Santa Catarina (SC) & 8 & 2,2 & 6 & 1,6 \\
Sergipe (SE) & 4 & 1,1 & 6 & 1,6 \\
São Paulo (SP) & 31 & 8,4 & 24 & 6,5 \\
Tocantins (TO) & 9 & 2,4 & 8 & 2,2 \\
\hline Total & 371 & 100 & 371 & 100 \\
\hline
\end{tabular}

Nas Tabelas 20 e 21 são apresentadas as estatísticas descritivas da duração do processo no TCU, quantidade de recursos e quantidade de pessoas em débito solidário.

Tabela 20.

Análises estatísticas na Amostra 1 e 2 referente a duração do processo no TCU, quantidade de recursos e quantidade de pessoas em débito solidário.

\begin{tabular}{|c|c|c|c|c|}
\hline \multicolumn{2}{|l|}{ Amostra 1} & $\begin{array}{c}\text { Duração do Processo } \\
\text { no TCU (anos) }\end{array}$ & $\begin{array}{l}\text { Quantidade de } \\
\text { Recursos }\end{array}$ & $\begin{array}{c}\text { Quantidade de pessoas em } \\
\text { débito solidário }\end{array}$ \\
\hline \multicolumn{2}{|l|}{ Média } & 4,03 &, 55 & 7,66 \\
\hline \multicolumn{2}{|l|}{ Mediana } & 3,00 &, 00 & 5,00 \\
\hline \multicolumn{2}{|l|}{ Moda } & 2 & 0 & 3 \\
\hline \multicolumn{2}{|c|}{ Desvio Padrão } & 2,92 & 1,68 & 6,61 \\
\hline \multicolumn{2}{|c|}{ Variância } & 8,54 & 2,83 & 43,80 \\
\hline \multicolumn{2}{|l|}{ Mínimo } & 1 & 0 & 2 \\
\hline \multicolumn{2}{|l|}{ Máximo } & 18 & 11 & 28 \\
\hline \multirow{3}{*}{ Percentil } & 25 & 2,00 & 00 & 3,00 \\
\hline & 50 & 3,00 & 00 & 5,00 \\
\hline & 75 & 6,00 &, 00 & 11,00 \\
\hline \multicolumn{2}{|c|}{ Missing } & 0 & 0 & 106 \\
\hline \multicolumn{2}{|c|}{ Total Analisado } & 371 & 371 & 265 \\
\hline
\end{tabular}


Tabela 20.

Análises estatísticas na Amostra 1 e 2 referente a duração do processo no TCU, quantidade de recursos e quantidade de pessoas em débito solidário.

\begin{tabular}{|c|c|c|c|c|}
\hline \multicolumn{2}{|c|}{ Amostra 2} & $\begin{array}{l}\text { Duração do Processo } \\
\text { no TCU (anos) }\end{array}$ & $\begin{array}{c}\text { Quantidade de } \\
\text { Recursos }\end{array}$ & $\begin{array}{c}\text { Quantidade de pessoas em } \\
\text { débito solidário }\end{array}$ \\
\hline \multicolumn{2}{|l|}{ Media } & 4,06 & ,54 & 7,68 \\
\hline \multicolumn{2}{|c|}{ Mediana } & 3,00 &, 00 & 5,00 \\
\hline \multicolumn{2}{|c|}{ Moda } & 3 & 0 & 2 \\
\hline \multicolumn{2}{|c|}{ Desvio Padrão } & 2,97 & 1,36 & 7,98 \\
\hline \multicolumn{2}{|c|}{ Variância } & 8,87 & 1,86 & 63,68 \\
\hline \multicolumn{2}{|c|}{ Mínimo } & 1 & 0 & 2 \\
\hline \multicolumn{2}{|c|}{ Máximo } & 17 & 11 & 51 \\
\hline \multirow{3}{*}{$\begin{array}{l}\text { Percen } \\
\text { til }\end{array}$} & 25 & 2,00 & 00 & 2,00 \\
\hline & 50 & 3,00 & ,00 & 5,00 \\
\hline & 75 & 5,00 & ,00 & 10,00 \\
\hline \multicolumn{2}{|l|}{ Missing } & 0 & 0 & 109 \\
\hline \multicolumn{2}{|c|}{ Total Analisado } & 371 & 371 & 262 \\
\hline
\end{tabular}

Outro dado analisado foi a porcentagem da multa do art. 57 e 58 . A multa referente ao art. 57 pode chegar até a $100 \%$ do valor do débito e a multa do artigo 58 varia de $5 \%$ a $95 \%$ de um valor anualmente definido pelo TCU. A média da porcentagem da multa referente ao art. 57 foi de $16,78 \%$ e de $15,9 \%$ e referentes a multa do art. 58 foi de 13,4 e $13,6 \%$ na Amostra 1 e 2 respectivamente. $\mathrm{O}$ cálculo da porcentagem da multa do art. 58 foi feito baseado no valor anual da multa estabelecida pelo TCU, ou seja, a porcentagem foi feita com base no ano que o processo do TCU foi finalizado.

Tabela 21.

Médias, desvio padrão, variância das porcentagens das multas art. 57 e 58 da Amostra 1 e 2.

\begin{tabular}{lcccccc}
\hline Amostra 1 & N & Mínimo & Máximo & Média & Desvio Padrão & Variância \\
\hline $\begin{array}{l}\text { Porcentagem Multa } \\
\text { art. 57 }\end{array}$ & 287 &, 31 & 100,00 & 16,82 & 16,56 & 274,44 \\
$\begin{array}{l}\text { Porcentagem Multa } \\
\text { art. 58 }\end{array}$ & 55 & 5,0 & 95,00 & 13,56 & 13,06 & 170,73 \\
\hline
\end{tabular}


Tabela 21.

Médias, desvio padrão, variância das porcentagens das multas art. 57 e 58 da Amostra 1 e 2.

\begin{tabular}{lcccccc}
\hline Amostra 2 & N & Mínimo & Máximo & Média & Desvio Padrão & Variância \\
\hline $\begin{array}{l}\text { Porcentagem Multa } \\
\text { art. 57 }\end{array}$ & 267 &, 11 & 84,00 & 15,92 & 13,43 & 180,59 \\
$\begin{array}{l}\text { Porcentagem Multa } \\
\text { art. 58 }\end{array}$ & 70 & 3,00 & 91,00 & 13,63 & 13,13 & 172,64 \\
\hline
\end{tabular}

Na Tabela 22 observa as frequências relativas e a porcentagem dos motivos de instauração e das multas (art. 57 e art. 58) na Amostra 1. A maior porcentagem do dano ao erário (alínea "c") foi de 25,3 \% do total de multas do art. 57 e na combinação das alíneas "b" e "c" a porcentagem foi de 11,3\%. As multas do art. 58 ocorrem com maior quantidade na prática de ato de gestão ilegal, ilegítimo, antieconômico (alínea "b") totalizando 8,9\%.

Tabela 22.

Motivo de instauração do processo, frequências absolutas e porcentagens das multas dos art. 57 e 58 na Amostra 1.

Amostra 1

Multa art. 57

Multa art. 58

\begin{tabular}{lcccc} 
Motivo da Instauração do Processo & $\begin{array}{c}\text { Frequência } \\
\text { Absoluta }\end{array}$ & $\begin{array}{c}\text { Porcentagem } \\
(\%)\end{array}$ & $\begin{array}{c}\text { Frequência } \\
\text { Absoluta }\end{array}$ & $\begin{array}{c}\text { Porcentagem } \\
(\%)\end{array}$ \\
\hline Sigiloso & 8 & 2,2 & 8 & 2,2 \\
Sem multa & 71 & 19,1 & 308 & 83,0 \\
Alínea "a" & 39 & 10,5 & 5 & 1,4 \\
Alínea "b" & 22 & 5,9 & 33 & 8,9 \\
Alínea "c" & 94 & 25,3 & 5 & 1,4 \\
Alínea "d" & 45 & 12,1 & 1 & 0,3 \\
\hline
\end{tabular}


Tabela 22 .

Motivo de instauração do processo, frequências absolutas e porcentagens das multas dos art. 57 e 58 na Amostra 1.

\begin{tabular}{|c|c|c|c|c|}
\hline Alínea "a" e "b" & 7 & 1,9 & 0 & 0,0 \\
\hline Alínea "a" e "c" & 15 & 4,0 & 1 & 0,3 \\
\hline Alínea "a" e "d" & 1 & 0,3 & 0 & 0,0 \\
\hline Alínea "b" e "c" & 42 & 11,3 & 6 & 1,6 \\
\hline Alínea "b" e "d" & 9 & 2,4 & 1 & 0,3 \\
\hline Alínea "c" e "d" & 10 & 2,7 & 1 & 0,3 \\
\hline Alínea "a", "b" e “c" & 1 & 0,3 & 0 & 0,0 \\
\hline Alínea "a", "b" e "d" & 1 & 0,3 & 0 & 0,0 \\
\hline Alínea “b", "c" e “d" & 5 & 1,4 & 2 & 0,5 \\
\hline Alínea "a", "b", "c" e "d" & 1 & 0,3 & 0 & 0,0 \\
\hline Total & 371 & 100 & 371 & 100 \\
\hline
\end{tabular}

$\mathrm{Na}$ Tabela 23 foi descrita as frequências relativas e a porcentagem dos motivos de instauração e das multas (art. 57 e art. 58) na Amostra 2. O dano ao erário (alínea "c") foi de $22,1 \%$ de multas do art. 57 e na combinação das alíneas "b" e "c" foi de 12,4\%. As multas do art. 58 ocorrem com maior quantidade na prática de ato de gestão ilegal, ilegítimo, antieconômico (alínea "b"), 12,4\%. 
Tabela 23.

Motivo de instauração do processo, frequências absolutas e porcentagens das multas dos art. 57 e 58 na Amostra 2.

\begin{tabular}{|c|c|c|c|c|}
\hline \multirow[b]{3}{*}{$\begin{array}{l}\text { Motivo da Instauração do } \\
\text { Processo }\end{array}$} & \multicolumn{4}{|c|}{ Amostra 2} \\
\hline & \multicolumn{2}{|c|}{ Multa art. 57} & \multicolumn{2}{|c|}{ Multa art. 58} \\
\hline & $\begin{array}{l}\text { Frequência } \\
\text { Absoluta }\end{array}$ & $\begin{array}{c}\text { Porcentagem } \\
(\%)\end{array}$ & $\begin{array}{l}\text { Frequência } \\
\text { Absoluta }\end{array}$ & $\begin{array}{l}\text { Porcentagem } \\
(\%)\end{array}$ \\
\hline Sigiloso & 6 & 1,6 & 6 & 1,6 \\
\hline Sem multa & 96 & 25,9 & 295 & 79,5 \\
\hline Alínea “a” & 38 & 10,2 & 2 & 0,5 \\
\hline Alínea "b" & 17 & 4,6 & 46 & 12,4 \\
\hline Alínea “c”" & 82 & 22,1 & 8 & 2,2 \\
\hline Alínea “d” & 31 & 8,4 & 1 & 0,3 \\
\hline Alínea "a" e "b" & 4 & 1,1 & 2 & 0,5 \\
\hline Alínea "a" e "c" & 15 & 4,0 & 0 & 0,0 \\
\hline Alínea "a" e "d" & 5 & 1,4 & 0 & 0,0 \\
\hline Alínea "b" e "c" & 46 & 12,4 & 8 & 2,2 \\
\hline Alínea "b" e "d" & 11 & 2,9 & 1 & 0,3 \\
\hline Alínea "c" e "d" & 12 & 3,2 & 0 & 0,0 \\
\hline Alínea "a", "b" e “c" & 3 & 0,8 & 1 & 0,3 \\
\hline Alínea "a", "b" e "d" & 1 & 0,3 & 0 & 0,0 \\
\hline Alínea "b", "c" e "d" & 4 & 1,1 & 1 & 0,3 \\
\hline Alínea "a", "b", “c" e "d" & 0 & 0,0 & 0 & 0,0 \\
\hline Total & 371 & 100 & 371 & 100 \\
\hline
\end{tabular}

Em alguns casos o processo recebeu a multa do art. 57 e art. 58, os motivos de instauração da TCE relacionado com as multas foram descrita na Tabela 24. 
Tabela 24.

Motivo de instauração do processo que receberam multas de art. 57 e 58 na Amostra 1 e 2.

\begin{tabular}{lcccc}
\hline & \multicolumn{2}{c}{ Amostra 1 } & \multicolumn{2}{c}{ Amostra 2 } \\
& Multa art. 57 - Multa art. 58 & Multa art. 57 - Multa art. 58 \\
\cline { 2 - 5 } $\begin{array}{l}\text { Motivo da Instauração do } \\
\text { Processo }\end{array}$ & 1 & 20,0 & 0 & 0,00 \\
\hline Alínea "b" & 1 & 20,0 & 2 & 33,3 \\
Alínea "c" & 1 & 20,0 & 0 & 0,0 \\
Alínea "a" e "c" & 1 & 20,0 & 3 & 50,0 \\
Alínea "b" e "c" & 0 & 0,0 & 1 & 16,7 \\
Alínea "a", "b" e "c" & 1 & 20,0 & 0 & 0,0 \\
Alínea "b", "c" e "d" & 5 & 100 & 6 & 100 \\
Total & 5 & & & Porcentagem \\
\hline
\end{tabular}

Outra sanção analisada é a descrita no art. 60 da Lei 8.443 que prevê a inabilitação para exercício de cargo em comissão ou função de confiança no âmbito da Administração por um período que pode variar de 5 a 8 anos. Pode considerar essa sanção a mais grave da lei, tanto que, para ser aplicada é preciso que por maioria absoluta de seus membros do colegiado ou plenários, o a infração cometida seja considerada grave. De todas as sanções analisadas, essa foi a que ocorreu com menor frequência, 25 e 24 nas Amostras 1 e 2 respectivamente, por isso, foi realizado uma análise descritiva com essa sanção.

A Tabela 25 apresenta as frequências absolutas e a porcentagem em relação à sanção de inabilitação para o exercício de cargo público e o órgão instaurador, convênio e débito solidário, na Amostra 1 e 2. Nessa tabela a maior parte dos casos no qual essa sanção é aplicada envolve débito solidário, $92 \%$ na Amostra 1 e, $83,3 \%$ na Amostra 2. As duas amostras seguem a mesma tendência nos resultados descritos abaixo. 
Tabela 25.

Frequência absoluta e porcentagem em relação a instauração pelo TCU, débito solidário, convênio, processo em sigilo em relação a sanção de inabilitação para exercício de cargo em comissão ou função de confiança no âmbito da administração pública na Amostra 1 e 2.

\begin{tabular}{|c|c|c|c|c|}
\hline & \multicolumn{2}{|c|}{ Amostra 1} & \multicolumn{2}{|c|}{ Amostra 2} \\
\hline & $\begin{array}{c}\text { Frequência } \\
\text { Absoluta }\end{array}$ & $\begin{array}{c}\text { Porcentagem } \\
(\%)\end{array}$ & $\begin{array}{l}\text { Frequência } \\
\text { Absoluta }\end{array}$ & $\begin{array}{c}\text { Porcentagem } \\
(\%)\end{array}$ \\
\hline \multicolumn{5}{|c|}{ Instaurado pelo TCU } \\
\hline Sim & 3 & 12,0 & 1 & 4,2 \\
\hline Não & 22 & 88,0 & 23 & 95,8 \\
\hline Missing & 0 & 0,0 & 0 & 0,0 \\
\hline Total & 25 & 100 & 24 & 100 \\
\hline \multicolumn{5}{|c|}{ Convênio } \\
\hline Sim & 11 & 44,0 & 12 & 50,0 \\
\hline Não & 14 & 56,0 & 10 & 41,7 \\
\hline Missing & 0 & 0,0 & 2 & 8,3 \\
\hline Total & 25 & 100 & 24 & 100 \\
\hline \multicolumn{5}{|c|}{ Débito Solidário } \\
\hline Sim & 23 & 92,0 & 20 & 83,3 \\
\hline Não & 2 & 8,0 & 4 & 16,0 \\
\hline Missing & 0 & 0,0 & 0 & 0,0 \\
\hline Total & 25 & 100 & 24 & 100 \\
\hline
\end{tabular}

A Tabela 26 apresenta a frequência absoluta e as porcentagens dos casos de aplicação da sanção do art. 60 para os cargos públicos, nessa análise foi considerada as categorias criadas para serem utilizadas na regressão linear múltipla (próxima sessão do trabalho). Foram agrupados os cargos de prefeito e secretário, presidente e diretor e outros (incluído todos os 
demais cargos). Na Amostra 1, 60\% das aplicações da sanção incluíram "outros cargos" e na Amostra 2,75\% dos casos envolveram "prefeitos e secretários".

Tabela 26.

Frequência absoluta e porcentagem dos cargos dos responsáveis na TCE em relação a sanção de inabilitação para exercício de cargo em comissão ou função de confiança no âmbito da administração pública na Amostra 1 e 2.

\begin{tabular}{lcccc}
\hline & \multicolumn{2}{c}{ Amostra 1 } & \multicolumn{2}{c}{ Amostra 2 } \\
\cline { 2 - 5 } Cargos dos responsáveis & $\begin{array}{c}\text { Frequência } \\
\text { Absoluta }\end{array}$ & $\begin{array}{c}\text { Porcentagem } \\
(\%)\end{array}$ & $\begin{array}{c}\text { Frequência } \\
\text { Absoluta }\end{array}$ & $\begin{array}{c}\text { Porcentagem } \\
(\%)\end{array}$ \\
\hline Sigiloso & 4 & 16,0 & 1 & 4,2 \\
Prefeito e Secretário & 5 & 20,0 & 18 & 75,0 \\
Presidente e Diretor & 1 & 4,0 & 3 & 12,5 \\
Outros Cargos & 15 & 60,0 & 2 & 8,3 \\
Total & 25 & 100 & 24 & 100 \\
\hline
\end{tabular}

Uma última análise descritiva com a sanção do art. 60 foi na sua relação com o motivo de instauração do processo. Na Amostra 1 observar que $80 \%$ dos casos envolveram desfalque ou desvio, sendo $52 \%$ a alínea "d" e $28 \%$ a alínea "d" combinada com outra alínea. A mesma tendência foi notada na Amostra 2.

Essas análises descritivas podem ser úteis para se conhecer algumas das características dos processos de tomada de contas especial no TCU e verificar a possibilidade de explorar possíveis relações entre as variáveis com base em análises estatísticas inferenciais. 
Tabela 27.

Frequência absoluta e porcentagem aos motivos de instauração das TCE em relação a sanção de inabilitação para exercício de cargo em comissão ou função de confiança no âmbito da administração pública na Amostra 1 e 2.

\begin{tabular}{lcccc}
\hline & \multicolumn{2}{c}{ Amostra 1 } & \multicolumn{2}{c}{ Amostra 2 } \\
\cline { 2 - 5 } $\begin{array}{l}\text { Motivo da Instauração do } \\
\text { Processo }\end{array}$ & $\begin{array}{c}\text { Frequência } \\
\text { Absoluta }\end{array}$ & $\begin{array}{c}\text { Porcentagem } \\
(\%)\end{array}$ & $\begin{array}{c}\text { Frequência } \\
\text { Absoluta }\end{array}$ & $\begin{array}{c}\text { Porcentagem } \\
(\%)\end{array}$ \\
\hline Sigiloso & 4 & 16,0 & 4 & 16,7 \\
Alínea "a" & 0 & 0,0 & 2 & 8,3 \\
Alínea "b" & 1 & 4,0 & 0 & 0,0 \\
Alínea "c" & 0 & 0,0 & 2 & 8,3 \\
Alínea "d" & 13 & 52,0 & 8 & 33,3 \\
Alínea "b" e "c" & 2 & 8,0 & 3 & 12,5 \\
Alínea "b" e "d" & 1 & 4,0 & 3 & 12,5 \\
Alínea "c" e "d" & 4 & 16,0 & 2 & 8,33 \\
Total & 25 & 100 & 24 & 100 \\
\hline
\end{tabular}

\section{Análise Inferencial}

Foi realizada a regressão linear na análise dos dados para identificar possíveis relações entre as variáveis. Para isso, primeiramente, as seguintes variáveis quantitativas contínuas foram consideradas como dependentes, em diferentes análises de regressão linear múltipla: (1) valor da multa do art. 57, (2) porcentagem da multa do art. 57 e (3) valor da multa art. 58. Regressões múltiplas examinaram possíveis relações lineares entre essas variáveis dependentes como função das seguintes variáveis preditoras (ou independentes): montante do débito (contínua), montante analisado no processo (contínua), se houve recurso (categórica nominal), se tratava-se de convênio (categórica nominal), se houve débito solidário (categórica nominal) (Anexo IV). 
As variáveis independentes categóricas nominais, tais como cargos (prefeitos e secretários, presidentes e diretores e outros cargos) e motivos de instaurações dos processos (com base no art. 16, inciso III, alínea “a”, alínea “b”, alínea “c”, alínea “d” e “mais de um ato") foram transformadas em variáveis dummies. Isso é necessário quando a análise envolve vários preditores com duas ou mais categorias. Nesse caso, elas são codificadas em valores " 0 " e " 1 ". Para interpretar as variáveis dummies é preciso fazer uma análise comparativa, por exemplo, prefeitos e secretários versus presidentes e diretores, e assim por diante, sendo a categoria de comparação aquela não incluída na regressão. Todas as análises foram realizadas usando IBM SPSS Statistic 2, sendo o $\mathrm{N}=371$ em cada amostra (1 e 2). Foi utilizado como critério de confiança de $95 \%$ ou seja, p. $<0,05$.

As análises de regressão foram realizadas em três etapas. Primeiramente foram incluídas como preditoras todas as variáveis contínuas. As que foram significantemente relacionadas à variável dependente foram mantidas para a segunda etapa. Na segunda etapa, foram incluídas as variáveis dummies relacionadas ao cargo ocupado pelo responsável. Na terceira etapa, incluíram-se as dummies relacionadas às condutas impugnadas nos processos (ou motivo de instauração da TCE). Essas etapas foram realizadas para cada uma das variáveis dependentes examinadas.

A Tabela 28 apresenta os resultados da primeira etapa de análise, com a variável dependente multa do art. 57, apenas a variável independente montante do débito foi incluída. Observa-se que o preditor selecionado (montante do débito) explicou 40,4\% $\left(R^{2}=0,404\right)$ e 20,5\% na variabilidade no resultado na Amostra 1 e 2 respectivamente. O parâmetro B constante (“Constant") representa o intercepto da linha de regressão no eixo Y. Os parâmetros indicam que o aumento de $\mathrm{R} \$ 1,00$ no montante do débito representou um aumento de $\mathrm{R} \$ 0,11$ (Amostra 1), e de R \$ 0,01, (Amostra 2), no valor da multa do art. 57. 
Tabela 28

Regressão linear da variável dependente multa do art. 57 nas Amostras 1 e 2.

\begin{tabular}{clcccc}
\hline Amostra & & B & Std. Error & Beta & Sig. \\
\hline \multirow{2}{*}{1} & (Constant) & $-24562,81$ & 20856,84 & &, 24 \\
& $\begin{array}{l}\text { Montante do } \\
\text { Débito }\end{array}$ &, 11 &, 008 &, 62 &, 00 \\
\hline \multirow{2}{*}{2} & (Constant) & 22477,61 & 5694,57 & &, 00 \\
& $\begin{array}{l}\text { Montante do } \\
\text { Débito }\end{array}$ &, 01 &, 001 &, 43 &, 00 \\
\hline
\end{tabular}

Nota: Amostra $1-R 2=0,404$ e Amostra $2-R 2=0,205$

A Tabela 29 mostra os resultados da segunda etapa, na qual foi realizada uma regressão linear com a variável dependente da multa do art. 57 em função do montante do débito e dos cargos dos gestores (dummies). Na Amostra 1 não houve nenhuma relação significativa entre a variável multa do art. 57 e os cargos. Na Amostra 2 observa-se a mesma tendência, visto que nenhuma relação foi significativa.

Tabela 29

Regressão linear da variável dependente multa do art. 57 relacionado com as variáveis independentes dos cargos dos gestores na Amostra 1 e 2.

\begin{tabular}{lcccc}
\hline \multicolumn{1}{c}{ Amostra 1 } & B & Std. Error & Beta & Sig. \\
\hline (Constant) & $-10350,96$ & 6616,62 & & 0,11 \\
Montante do & 0,11 & 0,008 & 0,65 & 0,00 \\
$\begin{array}{l}\text { Débito } \\
\text { Presidente e }\end{array}$ & 9489,86 & 12822,01 & 0,03 & 0,46 \\
Diretor & 15007,79 & 12393,74 & 0,05 & 0,22 \\
Outros Cargos & $-858,64$ & 11356,00 & & 0,94 \\
\hline Constant) & 0,11 & 0,01 & 0,65 & 0,00 \\
Montante do & 5514,10 & 15286,00 & 0,02 & 0,71 \\
Débito & $-9495,07$ & 12820,34 & $-0,04$ & 0,45 \\
Outros Cargos & & & & \\
Prefeito e & & & & \\
Secretário & &
\end{tabular}


Tabela 29

Regressão linear da variável dependente multa do art. 57 relacionado com as variáveis independentes dos cargos dos gestores na Amostra 1 e 2.

\begin{tabular}{lcccc}
\hline \multicolumn{1}{c}{ Amostra 2 } & B & Std. Error & Beta & Sig. \\
\hline (Constant) & 13184,33 & 1830,07 & & 0,00 \\
$\begin{array}{l}\text { Montante do } \\
\text { Débito }\end{array}$ & 0,01 & 0,01 & 0,44 & 0,00 \\
$\begin{array}{l}\text { Presidente e } \\
\text { Diretor }\end{array}$ & $-6138,75$ & 3151,57 & $-0,10$ & 0,05 \\
Outros Cargos & $-1590,65$ & 3283,89 & $-0,02$ & 0,62 \\
\hline Constant) & 7045,61 & 2606,03 & & 0,01 \\
Montante do & 0,01 & 0,01 & 0,44 & 0,00 \\
Débito & 4548,10 & 3770,07 & 0,07 & 0,23 \\
$\begin{array}{l}\text { Outros Cargos } \\
\text { Prefeito e }\end{array}$ & 6138,75 & 3151,57 & 0,12 & 0,05 \\
Secretário & & & \\
\hline
\end{tabular}

Nota: Amostra $1-R 2=0,430 ;$ Amostra $2-R 2=0,202$.

Os resultados da terceira etapa podem ser observados na Tabela 30. A regressão considerou o valor da multa do art. 57 como função do montante do débito e dos atos que motivaram a instauração dos processos (art. 16 da 8443/92), sendo: alínea "a" (omissão no dever de prestar contas); alínea "b" (prática de ato de gestão ilegal, ilegítimo, antieconômico, ou infração à norma legal ou regulamentar de natureza contábil, financeira, orçamentária, operacional ou patrimonial); alínea "c" (dano ao erário decorrente de ato de gestão ilegítimo ao antieconômico); e alínea "d" (desfalque ou desvio de dinheiros, bens ou valores públicos). Na análise realizada pode-se notar que eventualmente o processo incluiu mais de um motivo de instauração e foi categorizada como mais de um ato (e.g. alínea "ab”, alínea” bc", alínea "abc", etc), essa categoria representou 30,5\% na Amostra 1 e $32 \%$ na Amostra 2.

Os atos nas alíneas "a", "b", “c", "d" e "mais de um ato" foram relacionados com a multa do art. 57, a porcentagem da multa do art. 57 e a multa do art. 58. Na Tabela 28 pode observar a regressão linear da variável dependente multa do art. 57. A mesma foi significante 
para a alínea "d" quando comparada as demais, ou seja, a multa tende a aumentar quando o processo tem como motivo de instauração o desfalque ou desvio.

As variáveis incluídas na regressão explicaram $39,8 \%\left(R^{2}=0,398\right)$ da variabilidade no valor da multa do art. 57, a variável dependente, na Amostra 1. Os parâmetros indicam que um aumento de $\mathrm{R} \$ 1,00$ no montante do débito esteve associado a um aumento, estatisticamente significante, de R \$ 0,11 no valor da multa. Além disso, os resultados mostraram um aumento significante no valor da multa para os casos em que o ato impugnado foi aquele previsto na alínea "d", ou seja, desfalque ou desvio, quando comparado aos atos de omissão no dever de prestar contas (alínea “a”), gestão ilegítima ou antieconômica (alínea “b”), e mais de um ato (combinações de mais de uma alínea). Quando comparado com o ato de gestão ilegítimo que causou dano ao erário (alínea “c"), a multa do art. 57 também foi maior para o caso de desfalque ou desvio (alínea “d”), sendo que a diferença esteve próxima do nível de significância estipulado $(p=0,05)$.

Tabela 30

Regressão linear da multa do art. 57 relacionado com o motivo da instauração na Amostra 1.

\begin{tabular}{lcccc}
\hline Amostra 1 & B & Std. Erro & Beta & Sig. \\
\hline (Constant) & $-7979,65$ & 8429,79 & & 0,34 \\
Montante do Débito & 0,11 & 0,01 & 0,62 & 0,00 \\
Alínea "a" & $-13708,21$ & 15293,89 & $-0,04$ & 0,37 \\
Alínea "b" & $-3279,39$ & 14011,75 & $-0,01$ & 0,82 \\
Alínea "c" & 5075,62 & 11745,61 & 0,02 & 0,67 \\
Alínea "d" & 33592,59 & 14724,74 & 0,11 & 0,02 \\
\hline (Constant) & $-21687,86$ & 12982,01 & & 0,09 \\
Montante do Débito & 0,19 & 0,01 & 0,62 & 0,00 \\
Alínea "b" & 10428,82 & 17111,51 & 0,04 & 0,54 \\
Alínea "c" & 18783,83 & 15265,44 & 0,08 & 0,21 \\
Alínea "d" & 47300,79 & 17685,56 & 0,15 & 0,01 \\
Mais de um ato & 13708,21 & 15293,88 & 0,06 & 0,37 \\
\hline
\end{tabular}


Tabela 30

Regressão linear da multa do art. 57 relacionado com o motivo da instauração na Amostra 1.

\begin{tabular}{lcccc}
\hline (Constant) & $-11259,04$ & 11311,38 & & 0,32 \\
Montante do Débito & 0,11 & 0,01 & 0,62 & 0,00 \\
Alínea "c" & 8355,02 & 14040,19 & 0,04 & 0,55 \\
Alínea "d" & 36871,98 & 16587,39 & 0,12 & 0,03 \\
Mais de um ato & 3279,39 & 14011,75 & 0,01 & 0,82 \\
Alínea "a" & $-10428,82$ & 17111,51 & $-0,03$ & 0,54 \\
\hline Constant) & $-2903,79$ & 8552,02 & & 0,73 \\
Montante do Débito & 0,11 & 0,01 & 0,62 & 0,00 \\
Alínea "d" & 28516,88 & 14705,23 & 0,09 & 0,05 \\
Mais de um ato & $-5075,71$ & 11729,15 & $-0,02$ & 0,66 \\
Alínea "a" & $-18783,86$ & 15244,05 & $-0,06$ & 0,22 \\
Alínea "b" & $-8273,79$ & 13942,64 & $-0,03$ & 0,55
\end{tabular}

Nota: Amostra $1-R 2=0,398$

A Tabela 31 mostra os resultados dessa mesma análise para os dados da Amostra 2. As variáveis incluídas no modelo explicaram $29,6 \%\left(R^{2}=0,296\right)$ da variação no valor da multa do art. 57. Aumento no montante do débito esteve significantemente associado a aumento no valor da multa, porém com parâmetro menor que para a outra amostra ( $R \$ 0,01$ para $R \$ 1,00)$. Novamente, a multa aplicada para os casos de desfalque ou desvio (alínea "d") foi significantemente maior do que aquela aplicada para os outros atos. Além disso, a multa foi significantemente menor para os casos de gestão ilegítima (alínea "b") do que para casos de ato de gestão ilegítimo que causou dano ao erário (alínea "c") e casos que envolveram mais de um ato. 
Tabela 31

Regressão linear da multa do art. 57 relacionado com o motivo da instauração na Amostra 2.

\begin{tabular}{lcccc}
\hline Amostra 1 & B & Std. Erro & Beta & Sig. \\
\hline (Constant) & 14351,35 & 2162,39 & & 0,0 \\
Montante do Débito & 0,01 & 0,01 & 0,39 & 0,00 \\
Alínea "a" & $-6045,69$ & 4215,58 & $-0,07$ & 0,15 \\
Alínea "b" & $-13641,44$ & 3476,99 & $-0,19$ & 0,00 \\
Alínea "c" & $-4502,45$ & 3243,25 & $-0,07$ & 0,17 \\
Alínea "d" & 20678,36 & 4515,12 & 0,22 & 0,00 \\
\hline (Constant) & 8346,93 & 3541,96 & & 0,02 \\
Montante do Débito & 0,01 & 0,01 & 0,39 & 0,00 \\
Alínea "b" & $-7636,68$ & 4470,09 & $-0,11$ & 0,09 \\
Alínea "c" & 1502,72 & 4294,33 & 0,02 & 0,73 \\
Alínea "d" & 26684,72 & 5328,38 & 0,29 & 0,00 \\
Mais de um ato & 6092,81 & 4153,26 & 0,10 & 0,14 \\
(Constant) & 934,13 & 2698,56 & & 0,73 \\
Montante do Débito & 0,01 & 0,01 & 0,39 & 0,00 \\
Alínea "c" & 8916,11 & 3628,16 & 0,14 & 0,01 \\
Alínea "d" & 34099,01 & 4805,38 & 0,37 & 0,00 \\
Mais de um ato & 13505,97 & 3460,95 & 0,23 & 0,00 \\
Alínea "a" & 7372,02 & 4516,25 & 0,08 & 0,10 \\
\hline (Constant) & 9836,06 & 2419,28 & & 0,00 \\
Montante do Débito & 0,01 & 0,01 & 0,39 & 0,00 \\
Alínea "d" & 25195,02 & 4619,45 & 0,27 & 0,00 \\
Mais de um ato & 4603,55 & 3235,90 & 0,08 & 0,16 \\
Alínea "a" & $-1530,21$ & 4348,89 & $-0,02$ & 0,73 \\
Alínea "b" & $-9125,91$ & 3636,71 & $-0,13$ & 0,01 \\
\hline
\end{tabular}

Nota: Amostra $2-R 2=, 296$

Pode-se observar na Tabela 32 que a regressão linear da porcentagem da multa do art. 57 indicou que o montante do débito foi a única relação significante, com uma relação inversa. Ou seja, quanto maior foi o montante do débito menor tendeu a ser a porcentagem da multa do art. 57. Pode-se dizer que o montante do débito explicou apenas $4,2 \%\left(R^{2}=0,042\right)$ da variação da porcentagem da multa do art. 57 na Amostra 1 e explica 4,7\% $\left(R^{2}=0,047\right)$ na Amostra 2. 
Os parâmetros indicam que o aumento no valor do débito (a cada $R \$ 1,00$ ) representa uma diminuição de $\mathrm{R}$-6,325 na Amostra 1 e de R\$ -1,567 na Amostra 2.

Tabela 32

Regressão linear da variável dependente porcentagem da multa do art. 57 na Amostra 1 e 2.

\begin{tabular}{llcccc}
\hline Amostra & & B & Std. Error & Beta & Sig. \\
\hline \multirow{2}{*}{1} & (Constant) & 16,60 & 4,40 & & 0,00 \\
& Montante do Débito & $-6,33$ & 0,00 & $-0,25$ & 0,00 \\
\hline \multirow{2}{*}{2} & (Constant) & 18,80 & 3,59 & & 0,00 \\
& Montante do Débito & $-1,57$ & 0,00 & $-0,17$ & 0,00 \\
\hline
\end{tabular}

Nota: Amostra $1-R 2=0,042 ;$ Amostra $2=R 2=0,047$

A Tabela 33 mostra os resultados da regressão linear com a variável dependente da porcentagem da multa do art. 57 em função do montante do débito e dos cargos dos gestores (dummies). Na Amostra 1 não houve nenhuma relação significativa entre a variável porcentagem da multa do art. 57 e os cargos. Na Amostra 2 observa-se a mesma tendência, visto que nenhuma relação foi significativa.

Tabela 33

Regressão linear da variável dependente porcentagem da multa do art. 57 relacionado com as variáveis independentes dos cargos dos gestores na Amostra 1 e 2.

\begin{tabular}{lcccc}
\hline Amostra 1 & B & Std. Error & Beta & Sig. \\
\hline (Constant) & 17,01 & 1,33 & & 0,00 \\
Montante do Débito & $-3,62$ & 0,00 & $-0,15$ & 0,02 \\
Presidente e Diretor & $-1,42$ & 2,78 & $-0,03$ & 0,61 \\
Outros Cargos & 3,76 & 2,70 & 0,09 & 0,17 \\
\hline (Constant) & 15,87 & 2,56 & & 0,00 \\
Montante do Débito & $-3,65$ & 0,00 & $-0,15$ & 0,02 \\
Outros Cargos & 4,91 & 3,42 & 0,12 & 0,15 \\
Prefeito e Secretário & 1,07 & 2,80 & 0,03 & 0,70 \\
\hline
\end{tabular}


Tabela 33

Regressão linear da variável dependente porcentagem da multa do art. 57 relacionado com as variáveis independentes dos cargos dos gestores na Amostra 1 e 2.

\begin{tabular}{lcccc}
\hline Amostra 2 & B & Std. Error & Beta & Sig. \\
\hline (Constant) & 17,52 & 1,26 & & 0,00 \\
Montante do Débito & $-1,73$ & 0,00 & $-0,19$ & 0,01 \\
Presidente e Diretor & $-1,13$ & 2,23 & $-0,04$ & 0,61 \\
Outros Cargos & $-1,98$ & 2,44 & $-0,06$ & 0,42 \\
\hline (Constant) & 16,39 & 1,88 & & 0,00 \\
Montante do Débito & $-1,73$ & 0,00 & $-0,19$ & 0,01 \\
Outros Cargos & $-0,84$ & 2,80 & $-0,02$ & 0,76 \\
Prefeito e Secretário & 1,13 & 2,23 & 0,04 & 0,61 \\
\hline
\end{tabular}

Nota: Amostra $1-R 2=0,035 ;$ Amostra $2-R 2=0,038$

A Tabela 34 descreve a regressão da porcentagem da multa do art. 57 com os motivos de instauração das TCE. As variáveis da regressão explicaram 9,30\% $\left(R^{2}=0,093\right)$ da variabilidade na porcentagem da multa do art. 57, a variável dependente, na Amostra 1. Os parâmetros indicam que um aumento de $\mathrm{R} \$ 1,00$ no montante do débito esteve associado a um diminuição, estatisticamente significante, de $\mathrm{R} \$ 4,08$ na porcentagem da multa. Os resultados mostraram um aumento significante no valor da multa para os casos em que o ato impugnado foi aquele previsto na alínea "d", ou seja, desfalque ou desvio, quando comparado aos atos de omissão no dever de prestar contas (alínea “a”), gestão ilegítima ou antieconômica (alínea "b”), e mais de um ato (combinações de mais de uma alínea) e o ato de gestão ilegítimo que causou dano ao erário (alínea “c”). 
Tabela 34

Regressão linear da porcentagem da multa do art. 57 relacionado com o motivo da instauração na Amostra 1.

\begin{tabular}{|c|c|c|c|c|}
\hline Amostra 1 & B & Std. Erro & Beta & Sig. \\
\hline (Constant) & 17,44 & 1,71 & & 0,00 \\
\hline Montante do Débito & $-4,08$ & 0,00 & $-0,17$ & 0,00 \\
\hline Alínea “a” & $-5,22$ & 3,06 & $-0,11$ & 0,09 \\
\hline Alínea "b" & $-6,18$ & 4,22 & $-0,09$ & 0,15 \\
\hline Alínea "c" & 0,80 & 2,35 & 0,02 & 0,73 \\
\hline Alínea “d” & 8,58 & 2,96 & 0,19 & 0,00 \\
\hline$\overline{\text { (Constant) }}$ & 12,22 & 2,59 & & 0,00 \\
\hline Montante do Débito & $-4,08$ &, 00 & $-0,17$ & 0,00 \\
\hline Alínea "b" & $-0,96$ & 4,64 & $-0,01$ & 0,84 \\
\hline Alínea “c" & 6,02 & 3,04 & 0,17 & 0,05 \\
\hline Alínea “d” & 13,80 & 3,53 & 0,29 & 0,00 \\
\hline Mais de um ato & 5,22 & 3,06 & 0,15 & 0,09 \\
\hline (Constant) & 11,26 & 3,88 & & 0,05 \\
\hline Montante do Débito & $-4,08$ & 0,00 & $-0,17$ & 0,05 \\
\hline Alínea "c" & 6,98 & 4,21 & 0,19 & 0,09 \\
\hline Alínea “d” & 14,76 & 4,57 & 0,32 & 0,00 \\
\hline Mais de um ato & 6,18 & 4,22 & 0,17 & 0,14 \\
\hline Alínea "a" & 0,96 & 4,64 & 0,02 & 0,84 \\
\hline (Constant) & 18,24 & 1,69 & & 0,00 \\
\hline Montante do Débito & $-4,08$ & 0,00 & $-0,17$ & 0,00 \\
\hline Alínea “d” & 7,78 & 2,93 & 0,17 & 0,01 \\
\hline Mais de um ato & $-0,80$ & 2,35 & $-0,02$ & 0,73 \\
\hline Alínea "a” & $-6,02$ & 3,03 & $-0,13$ & 0,05 \\
\hline Alínea "b" & $-7,32$ & 4,10 & $-0,11$ & 0,08 \\
\hline
\end{tabular}

Nota: $R 2=0,093$

A Tabela 35 mostra os resultados da porcentagem da multa do art. 57 para os dados da Amostra 2 As variáveis incluídas no modelo explicaram 49,0\% $\left(R^{2}=0,490\right)$ da variação na 
porcentagem da multa do art. 57. Aumento no montante do débito é significantemente associado a diminuição a porcentagem da multa. Os parâmetros indicam que um aumento de $\mathrm{R} \$ 1,00$ no montante do débito esteve associado a um diminuição, estatisticamente significante, de $\mathrm{R} \$ 1,86$ no valor da multa A porcentagem da multa aplicada para os casos de desfalque ou desvio (alínea “d”) não foi significantemente maior para nenhuma das comparações realizadas.

Tabela 35

Regressão linear da porcentagem da multa do art. 57 relacionado com o motivo da instauração na Amostra 2.

\begin{tabular}{lcccc}
\hline Amostra 1 & B & Std. Erro & Beta & Sig. \\
\hline (Constant) & 15,23 & 1,33 & & 0,00 \\
Montante do Débito & $-1,86$ & 0,00 & $-0,19$ & 0,00 \\
Alínea "a" & 0,31 & 2,52 & 0,01 & 0,90 \\
Alínea "b" & $-0,44$ & 3,47 & $-0,01$ & 0,89 \\
Alínea "c" & 3,49 & 1,97 & 0,12 & 0,08 \\
Alínea "d" & 2,13 & 2,79 & 0,05 & 0,45 \\
\hline (Constant) & 15,43 & 2,12 & & 0,00 \\
Montante do Débito & $-1,86$ & 0,00 & $-0,19$ & 0,00 \\
Alínea "b" & $-0,65$ & 3,85 & $-0,01$ & 0,87 \\
Alínea "c" & 3,29 & 2,58 & 0,11 & 0,20 \\
Alínea "d" & 1,92 & 3,25 & 0,05 & 0,56 \\
Mais de um ato & $-0,17$ & 2,50 & $-0,01$ & 0,95 \\
\hline (Constant) & 14,59 & 3,12 & & 0,00 \\
Montante do Débito & $-1,86$ & 0,00 & $-0,19$ & 0,00 \\
Alínea "c" & 4,13 & 3,44 & 0,14 & 0,23 \\
Alínea "d" & 2,76 & 3,97 & 0,07 & 0,49 \\
Mais de um ato & 0,67 & 3,39 & 0,02 & 0,84 \\
Alínea "a" & 0,95 & 3,79 & 0,03 & 0,80 \\
\hline
\end{tabular}




\section{Tabela 35}

Regressão linear da porcentagem da multa do art. 57 relacionado com o motivo da instauração na Amostra 2.

\begin{tabular}{lcccc}
\hline (Constant) & 18,633 & 1,47 & & 0,00 \\
Montante do Débito & $-1,86$ & 0,00 & $-0,19$ & 0,00 \\
Alínea "d" & $-1,28$ & 2,85 & $-0,03$ & 0,65 \\
Mais de um ato & $-3,37$ & 1,97 & $-0,12$ & 0,09 \\
Alínea "a" & $-3,09$ & 2,59 & $-0,08$ & 0,24 \\
Alínea "b" & $-3,85$ & 3,52 & $-0,07$ & 0,28
\end{tabular}

Nota: $R 2=0,490$

A multa do art. 58 da Lei 8.443 deve ser aplicada quando a conta é julgada irregular sem resultar em dano ao erário, ou seja, ocorrer quando for apurada irregularidades previstas nas alíneas "a", "b" e "c" do inciso III do art. 16. A incidência dessa multa na Amostra 1 é de 63 casos e Amostra 2 é de 76 casos. Foi realizado uma regressão linear múltipla: do valor da multa art. 58. com possíveis relações com seguintes variáveis preditoras (ou independentes): montante do débito, montante analisado no processo, se houve recurso, se tratava-se de convênio, se houve débito solidário. Entretanto, nenhuma regressão foi significativa (Anexo V).

\section{Discussão}

O objetivo do Estudo 2 foi de analisar as contingências vigentes no julgamento das tomada de contas especial das contas julgadas irregulares, com ou sem débito ao erário, pelo Tribunal de Contas da União. Os resultados foram analisados em duas etapas: (1) análise descritiva e (2) análise inferencial.

A maior parte dos processos de TCE não são instauradas pelo Tribunal de Contas da União. O TCU tem função fiscalizadora e pode instaurar as TCE. Quando o faz, age como uma agência de controle externo. Entretanto, a rede jurídica envolvendo as TCE é ampla, o que pode 
explicar o maior volume de instauração ser externo ao TCU. No art. 8 da Lei Orgânica, a autoridade administrativa competente deve instaurar a tomada de contas especial para apuração dos fatos, identificando os responsáveis e quantificando o dano. Se não o fizer, pode responder no processo com responsabilidade solidária. Esse é outro elemento importante para explicar o volume de instauração das TCE por outros órgãos.

Entretanto, esses dados não são suficientes para assegurar que todos os processos irregulares se tornem TCE. Uma auditoria realizada em 1999 no Fundo Nacional de Desenvolvimento da Educação (FNDE) constatou que recebe-se anualmente cerca de 15 mil processos de prestações de contas para serem analisadas. $\mathrm{O}$ problema interno fica agravado quando se identifica a existência de 20 a 30 mil processos ainda pendentes de análise (Guimarães et al. 1999). Em 2010 o Ministério da Saúde emitiu 10.083 pareceres referente aos processos de prestação de contas e 509 TCE foram instauradas. Todavia, o que chama atenção é que foram abertos 3.154 diligências e desse montante total de processos, 5.747 estavam sendo reanalisados. O maior montante de TCE ser instaurado por outros órgãos corrobora o funcionamento da rede jurídica, porém, não garante sua eficácia no controle do comportamento do gestor.

Outro fator interessante a ser analisado é a alta recorrência de débito solidário nos processos analisados, representando 71,4\% e 70,6\% na Amostra 1 e 2. Como previsto no art. 8, a responsabilidade solidária pode acontecer em decorrência da omissão em instaurar um processo mesmo tendo percebido irregularidades. Além disso, o grande volume de processos com débito solidário pode advir da quantidade de pessoas que normalmente estão envolvidas nos contratos, convênios etc. Por exemplo, a quantidade de TCE envolvendo convênios na Amostra 1 foi de 59\% e, de 65\% na Amostra 2. Os convênios são firmados quando ocorre transferência de recursos financeiros dos orçamentos da União destinados à execução de 
programa de governo em regime de mútua cooperação. De um lado, o órgão da administração pública federal direta e do outro, órgão ou entidade da administração pública estadual, distrital ou municipal (TCU, 2014).

Verificando os cargos dos que tiveram suas contas julgadas como irregulares pelo TCU, identifica-se a maior incidência em prefeitos e secretários, $49,9 \%$ e 45,6, seguido por presidente e diretor, $17,3 \%$ e 21,8, e outros cargos, $18,9 \%$ e 22,6\%, na Amostra 1 e 2 respectivamente.

Os prazos médios de duração dos processos judiciais podem variar dependendo da instância judicial e/ou da própria natureza do processo. A ministra Laurita Vaz, do Superior Tribunal de Justiça (STJ), durante o $9^{\circ}$ Encontro Nacional do Poder Judiciário afirmou que a justiça deseja colocar como meta o compromisso de concluir em quatro anos o julgamento de processos em cada uma das instâncias da Justiça Federal (CNJ, 2015). Levando em consideração que um processo para chegar ao Supremo Tribunal Federal passará por três instâncias, poderíamos supor que o processo levaria pelo menos 16 anos para ser finalizado, se isso for implementado. Nos dados analisados neste estudo, a duração média dos processos no TCU é de 4,03 anos na Amostra 1 e 4,06 anos na Amostra 2. É importante ressaltar que o julgamento do Tribunais de Contas é definitivo, observados os recursos previstos no âmbito dos colegiados. A decisão é definitiva, não sujeita a reversibilidade de mérito pelo Poder Judiciário (Melo, 2011), salvo os casos que podem ir ao Supremo Tribunal Federal (STF). Vale ressaltar que na maioria das TCE não se observou recurso. Dos 371 casos analisados em $83 \%$ da Amostra 1 e 77,9\% da Amostra 2 não tiveram nenhum recurso.

Nas análises das regressões lineares, observou uma relação significativa entre o montante do débito e a multa do art. 57: quanto maior o débito, maior a multa aplicada. A tendência foi vista nas duas amostras. A Lei 8.443 no art. 57 prevê que o Tribunal pode aplicar uma multa de até cem por cento do valor atualizado do dano causado ao erário. Os dados mostram uma relação 
entre multa e débito conforme previsto na lei. Mesmo a lei prevendo uma multa de até $100 \%$ do valor do débito, nos dados analisados, a média da porcentagem da multa do art. 57 foi de 16,82\% na Amostra 1 e de 15,92\% na Amostra 2.

$\mathrm{O}$ art. 268 do Regimento Interno do TCU especifica o art. 58 da Lei 8443/92, prevendo multa entre $5 \%$ a $95 \%$ do valor pré-estabelecido pelo TCU (valores atualizados anualmente) para as contas julgadas irregulares, não havendo débito ao erário. Nos dados analisados, a média da porcentagem da multa relacionada ao art. 268 e art. 58 foi de 13,56\% na Amostra 1 e 13,63\% na Amostra 2. Com mínimo de 5\% e máximo 95\% na Amostra 1 e o mínimo de 3\% e máximo de $91 \%$ na Amostra 2.

As contas podem ser julgadas irregulares por 4 motivos, previstos no art. 16, inciso III, alínea a, b, c e d ou mesmo a combinação entre atos. O motivo mais recorrente é dano ao erário decorrente de ato de gestão ilegítimo ao antieconômico (alínea “c") sendo 28,6\% na Amostra 1 e 25,3\% na Amostra 2. O segundo motivo é prática de ato de gestão ilegal, ilegítimo, antieconômico, ou infração à norma legal ou regulamentar de natureza contábil, financeira, orçamentária, operacional ou patrimonial (alínea "b") que representa 15,6\% dos casos na Amostra 1 e 19,9\% na Amostra 2. A combinação entre as alíneas "b" e "c" aparece em terceiro, 14\% na Amostra 1 e 14,3\% na Amostra 2. Na relação entre os motivos de instauração e multa, a alínea "c" representa 31,3\% das multas do art. 57 na Amostra 1 e 29,8\% na Amostra 2. Já em relação a multa do art. 58 relaciona-se com a alínea "b", sendo 52,4\% na Amostra 1 e 60,5\% na Amostra 2. Esses resultados indicam que a alínea "b" do inciso III do art. 16 é o motivo de instauração da TCE que gera mais contas julgadas irregulares, porém sem débito.

Na regressão linear da multa do art. 57 com os motivos de instauração, observou-se uma relação significativa entre desvio e desfalque de dinheiros, bens ou valores públicos (alínea “d”) se comparado com os outros motivos de instauração (alínea "a", "b", "c" e mais de um ato). 
Essa tendência ocorreu na Amostra 1 e 2, ou seja, a multa do art. 57 tende a ser maior quando ocorre desfalque ou desvio. Mesmo não sendo dito claramente na Lei, o ato da alínea d parece implicar a má fé na gestão do recurso público, constituindo-se uma gestão antiética (cf. Tessaro, 2011). Independentemente dessa interpretação estar ou não correta, os valores estipulados pelo Tribunal indicam que o ato relacionado a desfalque ou desvio é considerado pelos Ministros como mais gravoso que os outros

Outra sanção analisada foi a do art. 60 da Lei 8443/92 que prevê a inabilitação do gestor se por irregularidades constatadas pelo Tribunal de Contas da União e por maioria absoluta de seus membros, considerar grave a infração cometida. Nesse caso, o responsável ficará inabilitado por um período de cinco a oito anos para o exercício de cargo em comissão ou função de confiança no âmbito da Administração Pública. De acordo com Costa (1999), a inabilitação da função pública é uma pena aplicável ao gestor (seja político, servidor público ou prestador de serviço) que tenha praticado algum ato ilícito. No caso específico do Decreto Lei $201 / 67$, o $§ 2^{\circ}$ do seu art. $1^{\circ}$ prevê que é necessário delimitar a extensão do dano, pois a inabilitação implicará no impedimento por um determinado tempo para o exercício de cargo ou função pública, eletivo ou de nomeação. Portanto, esse Decreto trata como sinônimos os termos ‘cargo’ e 'função pública’, que seriam de duas espécies: (a) eletivos, (b) de nomeação e (c) função pública (cf. Costa, 1999). A inabilitação é uma ferramenta utilizada para afastar os maus gestores, a fim de buscar resguardar o interesse público quando se fizer presente a prática de ato desonesto (cf. Santana, 2012). Devido ao baixo N, a análise realizada foi descritiva, mesmo sem poder analisar variáveis preditoras para a aplicação dessa sanção, fica evidente que a alínea “d” (desfalque ou desvio) é considerada a sanção mais grave. 
Na regressão linear dos parâmetros (1) multa do art. 57; (2) porcentagem da multa do art. 57 e (3) multa do art. 58 não ocorre nenhuma relação significativa com os cargos (prefeito/secretário, presidente/diretor e outros cargos).

\section{Considerações Finais}

Em conclusão, o presente trabalho contribuiu para a Análise Comportamental do Direito por pelo menos dois motivos: (1) a descrição e identificação das contingências jurídicas previstas na Lei 8443/92 e no Regimento Interno do TCU; e ainda, (2) a identificação das contingências vigentes na tomada de contas especial no julgamento das contas irregulares, como a lei prévio e como está sendo de fato aplicada.

O objetivo geral do trabalho foi analisar as contingências relacionadas ao processo de tomada de contas especial. No Estudo 1 foi aplicado o modelo da Análise Comportamental do Direito para descrever as leis e normas jurídicas como sistemas de contingências previstas. No Estudo 2 procurou-se identificar e descrever alguns aspectos relacionados às contingências vigentes nos processos que julgaram contas irregulares.

No Estudo 1 foi descrita a Lei $n^{\circ}$ 8443/92 e Regimento Interno do TCU (que complementa a Lei em questão analisada) e identificou-se nessa análise as três principais sanções aplicadas aos gestores de recursos públicos, previstas nos art. 57, art. 58 e art. 60. Além dessas sanções, considerou-se a porcentagem das multas, indicando a magnitude dessas sanções aplicadas (art. 57 e art. 58). A Análise Comportamental do Direito se mostrou uma ferramenta eficaz para a descrição das normas e contingências jurídicas em termos de contingências comportamentais. Nota-se que ao descrevê-las, por exemplo, no art. 60, a lei não é clara sobre quais comportamentos ou atos devem ser considerados como infração grave, ficando a cargo dos julgadores o delimitar tais comportamentos infracionários. 
O resultado do Estudo 1 serviu de base para realização do Estudo 2. Com base nas descrições do primeiro estudo, quatro variáveis dependentes foram selecionadas como parâmetro para a segunda análise: (1) Multa do art. 57 Lei 8443/92; (2) Porcentagem da multa do art. 57; (3) Multa art. 58 Lei 8443/92 e (4) Inabilitação do art. 60 da Lei 8443/92. Os resultados indicaram para uma relação direta entre montante do débito e multa do at. 57, porém, relação inversa entre o montante do débito e a porcentagem da multa do art. 57 . Na análise do art. 58 nenhuma regressão significativa foi observada, entretanto, nota-se que a motivo de instauração da alínea b recebe a maior quantidade de multas do art. 58, podendo supor ser esse o ato infracional que quase não gera débito. Desvio e desfalque parece ser o ato infracional mais grave, recebendo maiores multas do art. 57 e a sanção de inabilitação.

Mesmo se tratando de amostra pequena foi possível analisar em certa medida as contingências da lei que estão realmente sendo aplicadas. A parte descritiva do Estudo 2 permitiu uma melhor compreensão de variáveis importantes no comportamento do gestor, a relação das TCE com convênio, com determinados cargos e até os Estados de maior incidência. Na segunda parte da análise, fica evidente um tendência na aplicação dessa Lei, ou seja, desfalque e desvio parecem ser considerados os atos mais graves. Além disso, a sanção de inabilitação é mais aplicada aos servidores.

O presente trabalho apresenta contribuições que enriquecem a literatura da área de Análise Comportamental do Direito e a Análise do Comportamento, abrindo um campo teóricoaplicado para novas pesquisas. Estes estudos possuem relevância social, uma vez que investigam e descrevem as contingências jurídicas. Compreendê-las é importante para o arranjo ou ajustes das contingências para o alcance de metas sociais. Isso poderia proporcionar aos indivíduos um acréscimo de bem-estar social, bem como a coibição de comportamento 
delituoso. Contingências bem arranjadas implicaria no estabelecimento de normas sociais, o alcance de metas sociais e consequentemente, benefícios sociais (cf. Aguiar, 2013).

\section{Referências Bibliográficas}

Albuquerque, L. C. e Silva, F. M. (2006). Efeitos da exposição a mudanças nas contingências sobre o seguir regras. Psicologia: Teoria e Pesquisa, 22(1), 101-112.

Aguiar, J. C. de (2006). Análise Comportamental do Direito: Fundamentos para uma abordagem do direito como ciência comportamental aplicada. Tese de Doutorado. Universidade Federal de Santa Catarina.

Aguiar, J. C. de. (2013). O direito como sistema de contingências sociais. R. Fac. Dir. UFG, V. 37, n.02, p. 164 - 196, jul./dez.

Aguiar, J. C. de. (2014). Análise Comportamental do Direito: uma abordagem do direito como ciência do comportamento humano aplicada. Nomos, vol. 34, n. 2, p. 245-273.

Aguiar, R. A. R (2006). Alteridade e rede no Direito. Veredas do Direito. Belo Horizonte, v. 3, $n^{\circ} 6$, jul/dez, p.11-43.

Aguiar, J.C. e Chinelato, J.T. (2014). Interpretação do Direito e comportamento humano. Revista de Informação Legislativa, $\mathrm{n}^{\mathrm{o}} .203$, jul/set, p.111-125.

Araújo, B.J.R (2004). O Tribunal de Contas da União como protagonista do controle e na prevenção a corrupção pública brasileira. Dissertação de Mestrado, Universidade Federal de Pernambuco.

Baum, W. M. (1995). Rules, culture, and fitness. The Behavior Analyst, v. 18(1), p. 1-21.

Baum, W.M. (2005). Understanding behaviorism: behavior, culture and evolution. 2.ed. Oxford: Blackwell. 
Boynton, W. C.; Johnson, R. N.; Kell, W. G. (2002). Auditoria. Tradução de José Evaristo dos Santos. São Paulo: Atlas.

Brasil (2012). Constituição Federal (1988). Constituição da República Federativa do Brasil. Brasília, DF: Senado.

Catania, A. C. (1999). Aprendizagem: comportamento, linguagem e cognição. Porto Alegre: Artmed.

CNJ (2015). Justiça Federal quer processos julgados em quatro anos em cada instância. Disponível em: http://www.cnj.jus.br/noticias/cnj/81014-justica-federal-quer-processosjulgados-em-quatro-anos-em-cada-instancia

Controladoria Geral da União (2013). Tomada de Contas Especial: perguntas e respostas. Disponível em: $\quad$ http://www.cgu.gov.br/Publicacoes/auditoria-efiscalizacao/arquivos/tomadadecontasespecial.pdf

Costa, A. S. (1999). Inelegibilidade e inabilitação no Direito Eleitoral. Revista Jus Navigandi, Teresina, ano 4, n. 37, 1 dez. 1999. Disponível em: https://jus.com.br/artigos/1518

Costa, M. B. (2006). Corrupção, improbidade administrativa e o Tribunal de Contas da União. Faculdade de Direito da Universidade de Brasília. Brasília.

Costa, A.L.; Leite, L.C.; Bezerra, P.S.A. e Gaia, R.N.D.(2003). O controle externo das contas públicas: tendências atuais. Monografia de Pós Graduação Lato Senso - MBA em Gestão e Políticas Públicas. Fundação Getúlio Vargas. Macapá, AP.

Debert, P., Matos, M. A., e Andery, M. A. P. A. (2006). Discriminação condicional: definições, procedimentos e dados recentes. Revista Brasileira de Análise do Comportamento, 2, 37-52.

Eisenhardt, K. M (1989). Agency Theory: An Assessment And Review. Academy of Management. The Academy of Management Review; Jan; 14, 1; ABI/INFORM Global. 
Fernandes, J. U. J. (2008). Tribunais de Contas do Brasil: jurisdição e competência. 2 ed. Belo Horizonte: Fórum.

Flores, E. P. (2004). O conceito de regra na linguagem cotidiana e na Análise Experimental do Comportamento. Estudos de Psicologia (Natal), 9(2), 279-283

Galizio, M. (1979). Contingency-shaped and rule-governed behavior: Instructional control of human loss avoidance. Journal of the Experimental Analysis of Behavior, 31, 53-70.

Glenn, S. S. (1986). Metacontingencies in Walden Two. Behavior Analysis and Social Action, $6,2-8$.

Glenn, S. S. (1987). Rules as environmental events. The Analysis of Verbal Behavior, v. 5, p. 29-32.

Glenn, S. S. (1988). Contingencies and metacontingencies: Toward a synthesis of behavior analysis and cultural materialism. The Behavior Analyst, 11, 161-179.

Glenn, S. S. (1989). Verbal behavior and cultural practices. Behavior Analysis and Social Action, 7, 10-14.

Gregório, C. E. R. (2012). A Natureza Jurídica das Decisões do Tribunal de Contas da União. Pós Graduação Direito e Jurisdição. Escola da Magistratura do Distrito Federal: Brasília.

Guimarães, M.M.; Modena, C.C.; Oliveira, E.A.P.; Clemente, F.C.; Moraes, C.M. e Luna, F.O. (1999). Relatório de auditoria de desempenho. In: Portal do TCU. Disponível em: http://portal.tcu.gov.br/lumis/portal/file/fileDownload.jsp?inline=1\&fileId=8A8182A14D9 $\underline{\text { 2792C014D928429206578 }}$

Hayles, S. C., Barnes-Holmes, D. e Roche, B. (2000). Relational frame theory: a postskinnerian account of human language and cognition. New York: Kluer Academic/Plenum Publishers. 
Hayes, S.C., Zettle, R. e Rosenfarb, I. (1989). Rule-following. In S.C. Hayes (Org.), Rule governed behavior: Cognition, contingencies, and instructional control. (pp. 191-220). New York: Plenum.

Hayles, S. C., Glifford, E. V. e Hayes, G. J. (1998). Moral behavior and the development of verbal regulation. The Behavior Analyst, n. 21, p. 253-279.

Horta, R.L; Almeida, V.R. e Chilvarque, M. (2014). Avaliando o desenvolvimento da pesquisa empírica em Direito no Brasil: o caso do projeto pensando o direito. Revista de Estudos Empíricos em Direito (Brazil Journal of Empirical Legal Studies), vol.1, nº 2, Jul 2014, p.162-183.

IBGE (2016). Instituto Brasileiro de Geografia e Estatística. Disponível em: http://www.ibge.gov.br/home/estatistica/populacao/indicadores_sociais_municipais/tabela $\underline{1 \mathrm{a} . \operatorname{shtm}}$

Joyce, J. H. e Chase, P.N (1990). Effects of response variability on the sensitivity of rulegoverned behavior.Journal of the Experimental Analysis of Behavior s, 54, 251-262.

Lima, L. H. (2011). Controle externo: teoria, jurisprudência e mais de 500 questões. 4 ed. Rio de Janeiro: Elsevier.

Lima, R. K. (2008). Por uma Antropologia do Direito no Brasil. Ensaios de Antropologia e de Direito: acesso à justiça e processos institucionais de administração de conflitos e produção da verdade jurídica em uma perspectiva comparada. Rio de Janeiro: Lumens Juris, pp. 0138.

Lima, R.K. (1983). Por Uma Antropologia do Direito no Brasil. In J. Falcão (org.), Pesquisa Científica e Direito. Recife, Ed. Massangana/CNPq/Instituto Joaquim Nabuco

Lima, R. K.; Varella, A. (2008) Saber Jurídico e Direito à Diferença no Brasil: questões de teoria e método em uma perspectiva comparada. Ensaios de Antropologia e de Direito: 
acesso à justiça e processos institucionais de administração de conflitos e produção da verdade jurídica em uma perspectiva comparada. Rio de Janeiro: Lumens Juris, pp. 89-126. Loevinger, L. (1949) Jurimetrics: the methodology of legal inquiry. Disponível em: http://heinonline.org/HOL/LandingPage?handle=hein.journals/mnlr33\&div=28\&id=\&page

Kelsen, H. (1991). Teoria pura do direito. Tradução João Baptista Machado. São Paulo: Martins Fontes.

Korobkin, R. (2015). Pesquisa empírica em direito contratual: possibilidades e problemas. Revista de Estudos Empíricos em Direito (Brazilian Journal of Empirical legal Studies). Vol. $2, n^{\circ} 1$.

Luhmann, N. (1985). A sociological theory of law. Translated by E. King and M. Albrow. London: Routledge and Kegan Paul.

Machado, J. T. e Costa, R H. (2008). A lei 4.320 comentada e a lei de responsabilidade fiscal. Rio de Janeiro: Ibam.

Machado-Neto, A. L. (1987). Sociologia Jurídica. 6. ed. São Paulo. Saraiva.

Martins, A.L.A. (2009). O sistema único de saúde: contingências e metacontingência nas leis orgânicas da saúde. Dissertação de Mestrado, Universidade de Brasília, Brasília.

Matos, M.A. (1999). Análise Funcional do Comportamento. Rev. Estudos de Psicologia, PUCCampinas, v. 16, n.3, p. 8-18, setembro/dezembro.

Matos, M. A. (2001). Comportamento governado por regras. Revista Brasileira de Terapia Comportamental e Cognitiva, 3(2), 51-66.

Milani, A. e Derek, A. (2007). A má gestão no Brasil: $\mathrm{R} \$ 1$ de cada $\mathrm{R} \$ 3$ tem irregularidades. Disponível em: http://rollingstone.uol.com.br/edicao/15/a-ma-gestao-no-brasil-r-1-de-cada$\underline{\text { r-3-tem-irregularidades\#imagem0 }}$ 
Melo, P. S. F. (2011). A natureza jurídica das decisões dos Tribunais de Contas. Âmbito Jurídico, Rio Grande, XIV, n. 89, jun. Disponível em: <http://www.ambitojuridico.com.br/site/?n_link=revista_artigos_leitura\&artigo_id=9704\&revista_caderno=4> $>$.

Moreira, M. B., e Medeiros, C. A. (2007). Princípios básicos de análise do comportamento. Porto Alegre: Artmed.

Moore, J. (2008). Conceptual foundations of radical behaviorism. Cornwall-on-Hudson, NY: Sloan.

Nunes, M G. (2012). Jurimetria aplicada ao direito societário: Um estudo estatístico da dissolução de sociedade no Brasil. Tese de Doutorado em Direito Comercial. São Paulo: PUC-SP.

Pereira, G.C.C. (2005). Metacontingência e o Estatuto da Criança e do Adolescente: uma análise da correspondência entre a lei e os comportamentos dos aplicadores do direito e executores da lei. Dissertação de Mestrado, Universidade de Brasília, Brasília.

Peters, M. (2007). Implantando e gerenciando a lei Sarbanes Oxley: governança corporativa agregando valor aos negócios. São Paulo: Atlas.

Portal Brasil (2016). Governo federal é formado por ministérios, secretarias e órgãos especiais. Disponível em: http://www.brasil.gov.br/governo/2009/11/governo-federal-e-formado-por$\underline{\text { ministerios-secretarias-e-orgaos-especiais }}$

Prudêncio, M.R.A. (2005). Leis e Metacontingências: análise do controle do Estatuto da Criança e do Adolescente sobre práticas jurídicas em processos de infração de adolescentes no Distrito Federal. Dissertação de Mestrado, Universidade de Brasília, Brasília.

Santana, J. D. J. (2012). Improbidade administrativa: nomeação de servidor "comissionado" como forma de burlar o princípio do concurso público. In: Âmbito Jurídico, Rio Grande, 
XV, $\quad$ n. $100, \quad$ maio. Disponível em: $\underline{\text { http://ambito- }}$ juridico.com.br/site/?n_link=revista_artigos_leitura\&artigo_id=11588

Silva, F.S. (2016). Vetores, desafios e apostas possíveis na pesquisa empírica em Direito no Brasil. Revista de Estudos Empíricos em Direito (Brazilian Journal of Empirical Legal Studies). Vol. 03, nº 1, jan, p.24-53.

Scuro-Neto, P. (2009). Sociologia Geral e Jurídica. 6. ed. São Paulo. Saraiva.

Scott, J. F. (1971). Internalization of norms: a sociological theory of moral commitment. Englewood Cliffs: Prentice-Hall.

Sério, T. M. A. P. Andery, M. A., Gioia, P. S. e Micheletto, N. (2002). Controle de estímulos e comportamento operante: Uma introdução. São Paulo: EDUC.

Scheneider, S. M. (2012). The science of consequences: how they affect genes, change the brain, and impact our world. Amherst, N.Y.: Prometheus Books.

Shimoff, E., Catania, A. C., e Matthews B. A. (1981). Uninstructed human responding: Sensitivity of low-rate performance to schedule contingencies. Journal of the Experimental Analysis of Behavior, 36, 207-220.

Skinner, B. F. (1953/2006). Science and human behavior. New York: Free Press.

Skinner, B. F. (1969). Contingencies of reinforcement: A theoretical analysis. New York: Appleton-Century-Crofts.

Skinner, B. F. (1976). About behaviorism. New York: Alfred A. Knopf.

Skinner, B. F. (1981/2007). Seleção pelas Consequências. Revista Brasileira de Terapia Comportamental e Cognitiva, IX (1), 129-137. 
Teixeira, W. A. (2006). O controle da corrupção: desafios e oportunidades para o TCU. Monografia de conclusão de curso. Curso de Pós-Graduação Lato Sensu em Direito Público e controle externo para analises e técnicos do TCU. Brasília.

Tessaro, A. G. J. (2011). Natureza jurídica da responsabilidade dos agentes públicos em sede de tomada de contas especial .Revista Jus Navigandi, Teresina, ano 16, n. 2776, 6 fev. Disponível em: https://jus.com.br/artigos/18436.

TI (2014). Disponível em http://www.transparency.org/whatwedo. Recuperado em 16 de dezembro de 2014.

Tribunal de Contas da União. (2012). Secretaria de Planejamento. Governança e Gestão. Relatório Anual de atividades: 2012. Disponível em: http://portal2.tcu.gov.br/portal/page/portal/TCU/publicacoes_institucionais/relatorios/relat orios_atividades/2012_Relat\%C3\%B3rio_anual_de_Atividades.pdf

Tribunal de Contas da União. (2015). Portal do TCU. Disponível em: http://portal2.tcu.gov.br/TCU

Tribunal de Contas da União. (2014). Convênios e outros repasses. Disponível em: http://portal.convenios.gov.br/images/docs/MROSC/Publicacoes_Gov_OSC_e_Parceiros/

\section{Convenios_TCU_5edicao.PDF.pdf}

Todorov, J. C. (1987). A Constituição como metacontingência. Psicologia, Ciência e Profissão, 7(1), 9-13.

Todorov, J. C. (2005). Laws and the complex control of behavior. Behavior and Social Issues, $14,86-90$.

Todorov, J. C.; Moreira, M.; Prudêncio, M. R. A. e Pereira, G. C. C. (2004). O Estatuto da Criança e do Adolescente como metacontingência: um estudo de contingência e metacontingência no Estatuto da Criança e do Adolescente. Em: M. Z. S., Brandão; F. C. S., 
Conte; F. S., Brandão; Y. K., Ungberman; V. M., Silva; S. M., Oliane (Orgs), Sobre Comportamento e Cognição: Contingências e Metacontingências: Contexto Socioverbais e o Comportamento do Terapeuta. Vol. 13. Santo André, SP: ESETEC.

Torgrud, L. J., e Holborn, S.W. (1990). The effects of verbal performance descriptions on nonverbal operant responding. Journal of the Experimental Analysis of Behavior, 54 (3), 273-291.

Watson, A. (1993). Legal transplants: an approach to comparative law. London: The University of Georgia Press.

Weber, M. (1968). Economy and society. Berkeley: University of California Press.

Zabala, F. J.; Silveira, F. F. (2014). Jurimetria: estatística aplicada ao direito. Revista Direito e Liberdade, Natal, v. 16, n. 1, p. 87-103, jan./abr. Quadrimestral. Disponível em: http://www.esmarn.tjrn.jus.br/revistas/index.php/revista_direito_e_liberdade/article/view/7 32/ 596 


\section{ANEXO I}

Artigo 306 da Lei n ${ }^{\circ} 9.503$ de 23 de Setembro de 1997

Art. 306. Conduzir veículo automotor, na via pública, sob a influência de álcool ou substância de efeitos análogos, expondo a dano potencial a incolumidade de outrem:

Art. 306. Conduzir veículo automotor, na via pública, estando com concentração de álcool por litro de sangue igual ou superior a 6 (seis) decigramas, ou sob a influência de qualquer outra substância psicoativa que determine dependência:

Art. 306. Conduzir veículo automotor com capacidade psicomotora alterada em razão da influência de álcool ou de outra substância psicoativa que determine dependência: (Redação dada pela Lei $\mathrm{n}^{\circ} 12.760$, de 2012)

Penas - detenção, de seis meses a três anos, multa e suspensão ou proibição de se obter a permissão ou a habilitação para dirigir veículo automotor.

Parágrafo único. O Poder Executivo federal estipulará a equivalência entre distintos testes de alcoolemia, para efeito de caracterização do crime tipificado neste artigo.

(Incluído pela Lei no 11.705 , de 2008)

$\S 1$ o As condutas previstas no caput serão constatadas por: (Incluído pela Lei $\mathrm{n}^{\circ} 12.760$, de 2012)

I - concentração igual ou superior a 6 decigramas de álcool por litro de sangue ou igual ou superior a 0,3 miligrama de álcool por litro de ar alveolar; ou (Incluído pela Lei ${ }^{\circ} 12.760$, de 2012)

II - sinais que indiquem, na forma disciplinada pelo Contran, alteração da capacidade psicomotora. (Incluído pela Lei no 12.760 , de 2012)

$\S 20$ A verificação do disposto neste artigo poderá ser obtida mediante teste de alcoolemia, exame clínico, perícia, vídeo, prova testemunhal ou outros meios de prova em direito admitido, observado o direito à contraprova. (Incluído pela Lei $n^{\circ} 12.760$, de 2012)

$\S 20$ A verificação do disposto neste artigo poderá ser obtida mediante teste de alcoolemia ou toxicológico, exame clínico, perícia, vídeo, prova testemunhal ou outros meios de prova em direito admitido, observado o direito à contraprova. (Redação dada pela Lei no 12.971, de 2014) (Vigência)

§ 3o O Contran disporá sobre a equivalência entre os distintos testes de alcoolemia para efeito de caracterização do crime tipificado neste artigo. (Incluído pela Lei n 12.760 , de 2012)

§ 3o O Contran disporá sobre a equivalência entre os distintos testes de alcoolemia ou toxicológicos para efeito de caracterização do crime tipificado neste artigo. (Redação dada pela Lei $n^{\circ} 12.971$, de 2014) (Vigência) 


\begin{abstract}
ANEXO II
I - a prestação de contas do convênio não for apresentada no prazo fixado no inciso I do art. 72, observado o $\S 1^{\circ}$ do referido artigo desta Portaria; e II - a prestação de contas do convênio não for aprovada em decorrência de:
\end{abstract}

a) inexecução total ou parcial do objeto pactuado;

b) desvio de finalidade na aplicação dos recursos transferidos;

c) impugnação de despesas, se realizadas em desacordo com as disposições do termo celebrado ou desta Portaria;

d) não utilização, total ou parcial, da contrapartida pactuada, na hipótese de não haver sido recolhida na forma prevista no parágrafo único do art. 73 desta Portaria;

e) não utilização, total ou parcial, dos rendimentos da aplicação financeira no objeto do Plano de Trabalho, quando não recolhidos na forma prevista no parágrafo único do art. 73 desta Portaria;

f) inobservância do prescrito no $\S 1^{\circ}$ do art. 54 desta Portaria ou não devolução de rendimentos de aplicações financeiras, no caso de sua não utilização;

g) não devolução de eventual saldo de recursos federais, apurado na execução do objeto, nos termos do art. 73 desta Portaria; e

h) ausência de documentos exigidos na prestação de contas que comprometa o julgamento da boa e regular aplicação dos recursos.

$2^{\circ}$ A Tomada de Contas Especial será instaurada, ainda, por determinação dos órgãos de Controle Interno ou do Tribunal de Contas da União, no caso de omissão da autoridade competente em adotar essa medida. 


\begin{abstract}
ANEXO III
Art. 70. A fiscalização contábil, financeira, orçamentária, operacional e patrimonial da União e das entidades da administração direta e indireta, quanto à legalidade, legitimidade, economicidade, aplicação das subvenções e renúncia de receitas, será exercida pelo Congresso Nacional, mediante controle externo, e pelo sistema de controle interno de cada Poder.

* Parágrafo único. Prestará contas qualquer pessoa física ou jurídica, pública ou privada, que utilize, arrecade, guarde, gerencie ou administre dinheiros, bens e valores públicos ou pelos quais a União responda, ou que, em nome desta, assuma obrigações de natureza pecuniária.

* Nova redação dada pelo art. 12 da Emenda Constitucional nº 19, de 4.6.1998.
\end{abstract}

Art. 71. O controle externo, a cargo do Congresso Nacional, será exercido com o auxílio do Tribunal de Contas da União, ao qual compete:

I - apreciar as contas prestadas anualmente pelo Presidente da República, mediante parecer prévio, que deverá ser elaborado em sessenta dias a contar de seu recebimento;

II - julgar as contas dos administradores e demais responsáveis por dinheiros, bens e valores públicos da administração direta e indireta, incluídas as fundações e sociedades instituídas e mantidas pelo poder público federal, e as contas daqueles que derem causa a perda, extravio ou outra irregularidade de que resulte prejuízo ao erário público;

III - apreciar, para fins de registro, a legalidade dos atos de admissão de pessoal, a qualquer título, na administração direta e indireta, incluídas as fundações instituídas e mantidas pelo poder público, excetuadas as nomeações para cargo de provimento em comissão, bem como a das concessões de aposentadorias, reformas e pensões, ressalvadas as melhorias posteriores que não alterem o fundamento legal do ato concessório;

IV - realizar, por iniciativa própria, da Câmara dos Deputados, do Senado Federal, de comissão técnica ou de inquérito, inspeções e auditorias de natureza contábil, financeira, orçamentária, operacional e patrimonial, nas unidades administrativas dos Poderes Legislativo, Executivo e Judiciário, e demais entidades referidas no inciso II;

V - fiscalizar as contas nacionais das empresas supranacionais de cujo capital social a União participe, de forma direta ou indireta, nos termos do tratado constitutivo;

VI - fiscalizar a aplicação de quaisquer recursos repassados pela União, mediante convênio, acordo, ajuste ou outros instrumentos congêneres, a Estado, ao Distrito Federal ou a Município;

VII - prestar as informações solicitadas pelo Congresso Nacional, por qualquer de suas Casas, ou por qualquer das respectivas comissões, sobre a fiscalização contábil, financeira, orçamentária, operacional e patrimonial e sobre resultados de auditorias e inspeções realizadas; 
VIII - aplicar aos responsáveis, em caso de ilegalidade de despesa ou irregularidade de contas, as sanções previstas em lei, que estabelecerá, entre outras cominações, multa proporcional ao dano causado ao erário;

IX - assinar prazo para que o órgão ou entidade adote as providências necessárias ao exato cumprimento da lei, se verificada ilegalidade;

X - sustar, se não atendido, a execução do ato impugnado, comunicando a decisão à Câmara dos Deputados e ao Senado Federal;

XI - representar ao Poder competente sobre irregularidades ou abusos apurados.

$\S 1^{\circ}$ - No caso de contrato, o ato de sustação será adotado diretamente pelo Congresso Nacional, que solicitará, de imediato, ao Poder Executivo as medidas cabíveis.

$\S 2^{\circ}$ - Se o Congresso Nacional ou o Poder Executivo, no prazo de noventa dias, não efetivar as medidas previstas no parágrafo anterior, o Tribunal decidirá a respeito.

$\S 3^{\circ}$ - As decisões do Tribunal de que resulte imputação de débito ou multa terão eficácia de título executivo.

$\S 4^{\circ}$ - O Tribunal encaminhará ao Congresso Nacional, trimestral e anualmente, relatório de suas atividades.

\section{Lei $N^{\circ}$ 8.443, DE 16 DE JULHO DE 1992.}

Dispõe sobre a Lei Orgânica do Tribunal de Contas da União e dá outras providências.

\section{TÍTULO I \\ NATUREZA, COMPETÊNCIA E JURISDIÇÃO \\ Capítulo I \\ Natureza e Competência}

Art. $1^{\circ}$ Ao Tribunal de Contas da União, órgão de controle externo, compete, nos termos da Constituição Federal e na forma estabelecida nesta Lei:

I - julgar as contas dos administradores e demais responsáveis por dinheiros, bens e valores públicos das unidades dos poderes da União e das entidades da administração indireta, incluídas as fundações e sociedades instituídas e mantidas pelo poder público federal, e as contas daqueles que derem causa a perda, extravio ou outra irregularidade de que resulte dano ao Erário;

II - proceder, por iniciativa própria ou por solicitação do Congresso Nacional, de suas Casas ou das respectivas comissões, à fiscalização contábil, financeira, orçamentária, operacional e patrimonial das unidades dos poderes da União e das demais entidades referidas no inciso anterior;

III - apreciar as contas prestadas anualmente pelo Presidente da República, nos termos do art. 36 desta Lei; 
IV - acompanhar a arrecadação da receita a cargo da União e das entidades referidas no inciso I deste artigo, mediante inspeções e auditorias, ou por meio de demonstrativos próprios, na forma estabelecida no Regimento Interno;

V - apreciar, para fins de registro, na forma estabelecida no Regimento Interno, a legalidade dos atos de admissão de pessoal, a qualquer título, na administração direta e indireta, incluídas as fundações instituídas e mantidas pelo poder público federal, excetuadas as nomeações para cargo de provimento em comissão, bem como a das concessões de aposentadorias, reformas e pensões, ressalvadas as melhorias posteriores que não alterem o fundamento legal do ato concessório;

VI - efetuar, observada a legislação pertinente, o cálculo das quotas referentes aos fundos de participação a que alude o parágrafo único do art. 161 da Constituição Federal, fiscalizando a entrega dos respectivos recursos;

VII - emitir, nos termos do $\S 2^{\circ}$ do art. 33 da Constituição Federal, parecer prévio sobre as contas do Governo de Território Federal, no prazo de sessenta dias, a contar de seu recebimento, na forma estabelecida no Regimento Interno;

VIII - representar ao poder competente sobre irregularidades ou abusos apurados, indicando o ato inquinado e definindo responsabilidades, inclusive as de Ministro de Estado ou autoridade de nível hierárquico equivalente;

IX - aplicar aos responsáveis as sanções previstas nos arts. 57 a 61 desta Lei;

$\mathrm{X}$ - elaborar e alterar seu Regimento Interno;

XI - eleger seu Presidente e seu Vice-Presidente, e dar-lhes posse;

XII - conceder licença, férias e outros afastamentos aos ministros, auditores e membros do Ministério Público junto ao Tribunal, dependendo de inspeção por junta médica a licença para tratamento de saúde por prazo superior a seis meses;

XIII - propor ao Congresso Nacional a fixação de vencimentos dos ministros, auditores e membros do Ministério Público junto ao Tribunal;

XIV - organizar sua Secretaria, na forma estabelecida no Regimento Interno, e prover-lhe os cargos e empregos, observada a legislação pertinente;

$\mathrm{XV}$ - propor ao Congresso Nacional a criação, transformação e extinção de cargos, empregos e funções de quadro de pessoal de sua secretaria, bem como a fixação da respectiva remuneração;

XVI - decidir sobre denúncia que lhe seja encaminhada por qualquer cidadão, partido político, associação ou sindicato, na forma prevista nos arts. 53 a 55 desta Lei;

XVII - decidir sobre consulta que lhe seja formulada por autoridade competente, a respeito de dúvida suscitada na aplicação de dispositivos legais e regulamentares concernentes a matéria de sua competência, na forma estabelecida no Regimento Interno.

$\S 1^{\circ}$ No julgamento de contas e na fiscalização que lhe compete, o Tribunal decidirá sobre a legalidade, de legitimidade e a economicidade dos atos de gestão e das despesas deles decorrentes, bem como sobre a aplicação de subvenções e a renúncia de receitas.

$\S 2^{\circ} \mathrm{A}$ resposta à consulta a que se refere o inciso XVII deste artigo tem caráter normativo e constitui prejulgamento da tese, mas não do fato ou caso concreto.

$\S 3^{\circ}$ Será parte essencial das decisões do Tribunal ou de suas Câmaras:

I - o relatório do Ministro-Relator, de que constarão as conclusões da instrução (do relatório da equipe de auditoria ou do técnico responsável pela análise do processo, bem como do parecer das chefias imediatas, da unidade técnica), e do Ministério Público junto ao Tribunal;

II - fundamentação com que o Ministro-Relator analisará as questões de fato e de direito;

III - dispositivo com que o Ministro-Relator decidirá sobre o mérito do processo. 
Art. $2^{\circ}$ Para desempenho de sua competência o Tribunal receberá, em cada exercício, o rol de responsáveis e suas alterações, e outros documentos ou informações que considerar necessários, na forma estabelecida no Regimento Interno.

Parágrafo único. O Tribunal poderá solicitar ao Ministro de Estado supervisor da área, ou à autoridade de nível hierárquico equivalente a outros elementos indispensáveis ao exercício de sua competência.

Art. $3^{\circ}$ Ao Tribunal de Contas da União, no âmbito de sua competência e jurisdição, assiste o poder regulamentar, podendo, em conseqüência, expedir atos e instruções normativas sobre matéria de suas atribuições e sobre a organização dos processos que lhe devam ser submetidos, obrigando ao seu cumprimento, sob pena de responsabilidade.

Capítulo II

Jurisdição

Art. $4^{\circ} \mathrm{O}$ Tribunal de Contas da União tem jurisdição própria e privativa, em todo o território nacional, sobre as pessoas e matérias sujeitas à sua competência.

Art. $5^{\circ}$ A jurisdição do Tribunal abrange:

I - qualquer pessoa física, órgão ou entidade a que se refere o inciso I do art. $1^{\circ}$ desta Lei, que utilize, arrecade, guarde, gerencie ou administre dinheiros, bens e valores públicos ou pelos quais a União responda, ou que, em nome desta assuma obrigações de natureza pecuniária; ao Erário;

II - aqueles que derem causa a perda, extravio ou outra irregularidade de que resulte dano

III - os dirigentes ou liquidantes das empresas encampadas ou sob intervenção ou que de qualquer modo venham a integrar, provisória ou permanentemente, o patrimônio da União ou de outra entidade pública federal;

IV - os responsáveis pelas contas nacionais das empresas supranacionais de cujo capital social a União participe, de forma direta ou indireta, nos termos do tratado constitutivo.

$\mathrm{V}$ - os responsáveis por entidades dotadas de personalidade jurídica de direito privado que recebam contribuições para fiscais e prestem serviço de interesse público ou social;

VI - todos aqueles que lhe devam prestar contas ou cujos atos estejam sujeitos à sua fiscalização por expressa disposição de Lei;

VII - os responsáveis pela aplicação de quaisquer recursos repassados pela União, mediante convênio, acordo, ajuste ou outros instrumentos congêneres, a Estado, ao Distrito Federal ou a Município;

VIII - os sucessores dos administradores e responsáveis a que se refere este artigo, até o limite do valor do patrimônio transferido, nos termos do inciso XLV do art. $5^{\circ}$ da Constituição Federal;

IX - os representantes da União ou do Poder Público na assembleia geral das empresas estatais e sociedades anônimas de cujo capital a União ou o Poder Público participem, solidariamente, com os membros dos conselhos fiscal e de administração, pela prática de atos de gestão ruinosa ou liberalidade à custa das respectivas sociedades.

\section{TÍTULO II \\ JULGAMENTO E FISCALIZAÇÃO \\ Capítulo I \\ Julgamento de Contas \\ Seção I}

Tomada e Prestação de Contas

Art. $6^{\circ}$ Estão sujeitas à tomada de contas e, ressalvado o disposto no inciso XXXV do art.

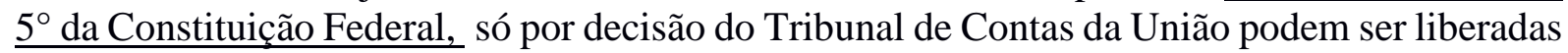
dessa responsabilidade as pessoas indicadas nos incisos I a VI do art. $5^{\circ}$ desta Lei. 
Art. $7^{\circ}$ As contas dos administradores e responsáveis a que se refere o artigo anterior serão anualmente submetidas a julgamento do Tribunal, sob forma de tomada ou prestação de contas, organizadas de acordo com normas estabelecidas em instrução normativa.

Parágrafo único. Nas tomadas ou prestações de contas a que alude este artigo devem ser incluídos todos os recursos, orçamentários e extra-orçamentários, geridos ou não pela unidade ou entidade.

Art. $8^{\circ}$ Diante da omissão no dever de prestar contas, da não comprovação da aplicação dos recursos repassados pela União, na forma prevista no inciso VII do art. $5^{\circ}$ desta Lei, da ocorrência de desfalque ou desvio de dinheiros, bens ou valores públicos, ou, ainda, da prática de qualquer ato ilegal, ilegítimo ou antieconômico de que resulte dano ao Erário, a autoridade administrativa competente, sob pena de responsabilidade solidária, deverá imediatamente adotar providências com vistas à instauração da tomada de contas especial para apuração dos fatos, identificação dos responsáveis e quantificação do dano.

$\S 1^{\circ}$ Não atendido o disposto no caput deste artigo, o Tribunal determinará a instauração da tomada de contas especial, fixando prazo para cumprimento dessa decisão.

$\S 2^{\circ}$ A tomada de contas especial prevista no caput deste artigo e em seu $\S 1^{\circ}$ será, desde logo, encaminhada ao Tribunal de Contas da União para julgamento, se o dano causado ao Erário for de valor igual ou superior à quantia para esse efeito fixada pelo Tribunal em cada ano civil, na forma estabelecida no seu Regimento Interno.

$\S 3^{\circ} \mathrm{Se}$ o dano for de valor inferior à quantia referida no parágrafo anterior, à tomada de contas especial será anexada ao processo da respectiva tomada ou prestação de contas anual do administrador ou ordenador de despesa, para julgamento em conjunto.

Art. $9^{\circ}$ Integrarão a tomada ou prestação de contas, inclusive a tomada de contas especial, dentre outros elementos estabelecidos no Regimento Interno, os seguintes:

I - relatório de gestão;

II - relatório do tomador de contas, quando couber;

III - relatório e certificado de auditoria, com o parecer do dirigente do órgão de controle interno, que consignará qualquer irregularidade ou ilegalidade constatada, indicando as medidas adotadas para corrigir as faltas encontradas;

IV - pronunciamento do Ministro de Estado supervisor da área ou da autoridade de nível hierárquico equivalente, na forma do art. 52 desta Lei.

Seção II

Decisões em Processo de Tomada ou Prestação de Contas

Art. 10. A decisão em processo de tomada ou prestação de contas pode ser preliminar, definitiva ou terminativa.

$\S 1^{\circ}$ Preliminar é a decisão pela qual o Relator ou o Tribunal, antes de pronunciar-se quanto ao mérito das contas, resolve sobrestar o julgamento, ordenar a citação ou a audiência dos responsáveis ou, ainda, determinar outras diligências necessárias ao saneamento do processo.

$\S 2^{\circ}$ Definitiva é a decisão pela qual o Tribunal julga as contas regulares, regulares com ressalva, ou irregulares.

$\S 3^{\circ}$ Terminativa é a decisão pela qual o Tribunal ordena o trancamento das contas que forem consideradas iliquidáveis, nos termos dos arts. 20 e 21 desta Lei.

Art. 11. O Relator presidirá a instrução do processo, determinando, mediante despacho singular, de ofício ou por provocação do órgão de instrução ou do Ministério Público junto ao Tribunal, o sobrestamento do julgamento, a citação ou a audiência dos responsáveis, ou outras providências consideradas necessárias ao saneamento dos autos, fixando prazo, na forma 
estabelecida no Regimento Interno, para o atendimento das diligências, após o que submeterá o feito ao Plenário ou à Câmara respectiva para decisão de mérito.

Art. 12. Verificada irregularidade nas contas, o Relator ou o Tribunal:

I - definirá a responsabilidade individual ou solidária pelo ato de gestão inquinado;

II - se houver débito, ordenará a citação do responsável para, no prazo estabelecido no Regimento Interno, apresentar defesa ou recolher a quantia devida,

III - se não houver débito, determinará a audiência do responsável para, no prazo estabelecido no Regimento Interno, apresentar razões de justificativa; não resulte dano ao Erário;

IV - adotará outras medidas cabíveis.

$\S 1^{\circ} \mathrm{O}$ responsável cuja defesa for rejeitada pelo Tribunal será cientificado para, em novo e improrrogável prazo estabelecido no Regimento Interno, recolher a importância devida.

$\S 2^{\circ}$ Reconhecida pelo Tribunal a boa-fé, a liquidação tempestiva do débito atualizado monetariamente sanará o processo, se não houver sido observada outra irregularidade nas contas.

$\S 3^{\circ} \mathrm{O}$ responsável que não atender à citação ou à audiência será considerado revel pelo Tribunal, para todos os efeitos, dando-se prosseguimento ao processo.

Art. 13. A decisão preliminar a que se refere o art. 11 desta Lei poderá, a critério do Relator, ser publicada no Diário Oficial da União.

Art. 14. O Tribunal julgará as tomadas ou prestações de contas até o término do exercício seguinte àquele em que estas lhes tiverem sido apresentadas.

Art. 15. Ao julgar as contas, o Tribunal decidirá se estas são regulares, regulares com ressalva, ou irregulares.

Art. 16. As contas serão julgadas:

I - regulares, quando expressarem, de forma clara e objetiva, a exatidão dos demonstrativos contábeis, a legalidade, a legitimidade e a economicidade dos atos de gestão do responsável;

II - regulares com ressalva, quando evidenciarem impropriedade ou qualquer outra falta de natureza formal de que não resulte dano ao Erário;

III - irregulares, quando comprovada qualquer das seguintes ocorrências:

a) omissão no dever de prestar contas;

b) prática de ato de gestão ilegal, ilegítimo, antieconômico, ou infração à norma legal ou regulamentar de natureza contábil, financeira, orçamentária, operacional ou patrimonial;

c) dano ao Erário decorrente de ato de gestão ilegítimo ao antieconômico;

d) desfalque ou desvio de dinheiros, bens ou valores públicos.

$\S 1^{\circ} \mathrm{O}$ Tribunal poderá julgar irregulares as contas no caso de reincidência no descumprimento de determinação de que o responsável tenha tido ciência, feita em processo de tomada ou prestarão de contas.

$\S 2^{\circ}$ Nas hipóteses do inciso III, alíneas c e d deste artigo, o Tribunal, ao julgar irregulares as contas, fixará a responsabilidade solidária:

a) do agente público que praticou o ato irregular, e

b) do terceiro que, como contratante ou parte interessada na prática do mesmo ato, de qualquer modo haja concorrido para o cometimento do dano apurado.

$\S 3^{\circ}$ Verificada a ocorrência prevista no parágrafo anterior deste artigo, o Tribunal providenciará a imediata remessa de cópia da documentação pertinente ao Ministério Público da União, para ajuizamento das ações civis e penais cabíveis.

Subseção I

Contas Regulares 
Art. 17. Quando julgar as contas regulares, o Tribunal dará quitação plena ao responsável. Subseção II

Contas Regulares com Ressalva

Art. 18. Quando julgar as contas regulares com ressalva, o Tribunal dará quitação ao responsável e lhe determinará, ou a quem lhe haja sucedido a adoção de medidas necessárias à correção das impropriedades ou faltas identificadas, de modo a prevenir a ocorrência de outras semelhantes.

Subseção III

Contas Irregulares

Art. 19. Quando julgar as contas irregulares, havendo débito, o Tribunal condenará o responsável ao pagamento da dívida atualizada monetariamente, acrescida dos juros de mora devidos, podendo, ainda, aplicar-lhe a multa prevista no art. 57 desta Lei, sendo o instrumento da decisão considerado título executivo para fundamentar a respectiva ação de execução.

Parágrafo único. Não havendo débito, mas comprovada qualquer das ocorrências previstas nas alíneas a, b e c do inciso III, do art. 16, o Tribunal aplicará ao responsável a multa prevista no inciso I do art. 58, desta Lei.

Subseção IV

Contas Iliquidáveis

Art. 20. As contas serão consideradas iliquidáveis quando caso fortuito ou de força maior, comprovadamente alheio à vontade do responsável, tornar materialmente impossível o julgamento de mérito a que se refere o art. 16 desta Lei.

Art. 21. O Tribunal ordenará o trancamento das contas que forem consideradas iliquidáveis e o conseqüente arquivamento do processo.

$\S 1^{\circ}$ Dentro do prazo de cinco anos contados da publicação da decisão terminativa no Diário Oficial da União, o Tribunal poderá, à vista de novos elementos que considere suficientes, autorizar o desarquivamento do processo e determinar que se ultime a respectiva tomada ou prestação de contas.

$\S 2^{\circ}$ Transcorrido o prazo referido no parágrafo anterior sem que tenha havido nova decisão, as contas serão consideradas encerradas, com baixa na responsabilidade do administrador.

Seção III

Execução das Decisões

Art. 22. A citação, a audiência, a comunicação de diligência ou a notificação far-se-á:

I - mediante ciência do responsável ou do interessado, na forma estabelecida no Regimento Interno;

II - pelo correio, mediante carta registrada, com aviso de recebimento;

III - por edital publicado no Diário Oficial da União quando o seu destinatário não for localizado.

Parágrafo único. A comunicação de rejeição dos fundamentos da defesa ou das razões de justificativas será transmitida ao responsável ou interessado, na forma prevista neste artigo.

Art. 23. A decisão definitiva será formalizada nos termos estabelecidos no Regimento Interno, por acórdão, cuja publicação no Diário Oficial da União constituirá: Erário;

I - no caso de contas regulares, certificado de quitação plena do responsável para com o

II - no caso de contas regulares com ressalva, certificado de quitação com determinação, nos termos do art. 18 desta Lei;

III - no caso de contas irregulares: 
a) obrigação de o responsável, no prazo estabelecido no Regimento Interno, comprovar perante o Tribunal que recolheu aos cofres públicos a quantia correspondente ao débito que lhe tiver sido imputado ou da multa cominada, na forma prevista nos arts. 19 e 57 desta Lei;

b) título executivo bastante para cobrança judicial da dívida decorrente do débito ou da multa, se não recolhida no prazo pelo responsável;

c) fundamento para que a autoridade competente proceda à efetivação das sanções previstas nos arts. 60 e 61 desta Lei.

Art. 24. A decisão do Tribunal, de que resulte imputação de débito ou cominação de multa, torna a dívida líquida e certa e tem eficácia de título executivo, nos termos da alínea b do inciso III do art. 23 desta Lei.

Art. 25. O responsável será notificado para, no prazo estabelecido no Regimento Interno, efetuar e comprovar o recolhimento da dívida a que se refere o art. 19 e seu parágrafo único desta Lei.

Parágrafo único. A notificação será feita na forma prevista no art. 22 desta Lei.

Art. 26. Em qualquer fase do processo, o Tribunal poderá autorizar o recolhimento parcelado da importância devida, na forma estabelecida no Regimento Interno, incidindo sobre cada parcela os correspondentes acréscimos legais.

Parágrafo único. A falta de recolhimento de qualquer parcela importará no vencimento antecipado do saldo devedor. da multa.

Art. 27. Comprovado o recolhimento integral, o Tribunal expedirá quitação do débito ou

Art. 28. Expirado o prazo a que se refere o caput do art. 25 desta Lei, sem manifestação do responsável, o Tribunal poderá:

I - determinar o desconto integral ou parcelado da dívida nos vencimentos, salários ou proventos do responsável, observados os limites previstos na legislação pertinente; ou

II - autorizar a cobrança judicial da dívida por intermédio do Ministério Público junto ao Tribunal, na forma prevista no inciso III do art. 81 desta Lei.

Art. 29. A decisão terminativa, acompanhada de seus fundamentos, será publicada no Diário Oficial da União.

Art. 30. Os prazos referidos nesta Lei contam-se da data:

I - do recebimento pelo responsável ou interessado:

a) da citação ou da comunicação de audiência;

b) da comunicação de rejeição dos fundamentos da defesa ou das razões de justificativa;

c) da comunicação de diligência;

d) da notificação;

II - da publicação de edital no Diário Oficial da União, quando, nos casos indicados no inciso anterior, o responsável ou interessado não for localizado;

III - nos demais casos, salvo disposição legal expressa em contrário, da publicação da decisão ou do acórdão no Diário Oficial da União.

Seção IV

Recursos

Art. 31. Em todas as etapas do processo de julgamento de contas será assegurado ao responsável ou interessado ampla defesa.

Art. 32. De decisão proferida em processo de tomada ou prestação de contas cabem recursos de:

I - reconsideração;

II - embargos de declaração;

III - revisão. 
Parágrafo único. Não se conhecerá de recurso interposto fora do prazo, salvo em razão da superveniência de fatos novos na forma prevista no Regimento Interno.

Art. 33. O recurso de reconsideração, que terá efeito suspensivo, será apreciado por quem houver proferido a decisão recorrida, na forma estabelecida no Regimento Interno, e poderá ser formulado por escrito uma só vez, pelo responsável ou interessado, ou pelo Ministério Público junto ao Tribunal, dentro do prazo de quinze dias, contados na forma prevista no art. 30 desta Lei.

Art. 34. Cabem embargos de declaração para corrigir obscuridade, omissão ou contradição da decisão recorrida.

$\S 1^{\circ}$ Os embargos de declaração podem ser opostos por escrito pelo responsável ou interessado, ou pelo Ministério Público junto ao Tribunal, dentro do prazo de dez dias, contados na forma prevista no art. 30 desta Lei.

$\S 2^{\circ}$ Os embargos de declaração suspendem os prazos para cumprimento da decisão embargada e para interposição dos recursos previstos nos incisos I e III do art. 32 desta Lei.

Art. 35. De decisão definitiva caberá recurso de revisão ao Plenário, sem efeito suspensivo, interposto por escrito, uma só vez, pelo responsável, seus sucessores, ou pelo Ministério Público junto ao Tribunal, dentro do prazo de cinco anos, contados na forma prevista no inciso III do art. 30 desta Lei, e fundar-se-á:

I - em erro de cálculo nas contas;

II - em falsidade ou insuficiência de documentos em que se tenha fundamentado a decisão recorrida;

III - na superveniência de documentos novos com eficácia sobre a prova produzida.

Parágrafo único. A decisão que der provimento a recurso de revisão ensejará a correção de todo e qualquer erro ou engano apurado.

\section{ANEXO IV \\ ATUREZA, COMPETÊNCIA E JURISDIÇÃO \\ CAPÍTULO I \\ NATUREZA E COMPETÊNCIA}

Art. $1^{\circ}$ Ao Tribunal de Contas da União, órgão de controle externo, compete, nos termos da Constituição Federal e na forma da legislação vigente, em especial da Lei $n^{\circ} 8.443$, de 16 de julho de 1992:

I - julgar as contas de qualquer pessoa física ou jurídica, pública ou privada, que utilize, arrecade, guarde, gerencie ou administre dinheiros, bens e valores públicos ou pelos quais a União responda ou que, em nome desta, assuma obrigações de natureza pecuniária, bem como daqueles que derem causa a perda, extravio ou outra irregularidade de que resulte dano ao erário;

II - realizar, por iniciativa própria ou por solicitação do Congresso Nacional, de suas casas ou das respectivas comissões, auditorias, inspeções ou acompanhamentos de natureza contábil, financeira, orçamentária, operacional ou patrimonial nas unidades administrativas dos Poderes Legislativo, Executivo e Judiciário e demais órgãos e entidades sujeitos à sua jurisdição; III - prestar as informações solicitadas pelo Congresso Nacional, por qualquer de suas casas, ou por suas comissões, sobre a fiscalização contábil, financeira, orçamentária, operacional e patrimonial e sobre resultados de auditorias e inspeções realizadas; 
IV - emitir pronunciamento conclusivo sobre matéria que seja submetida a sua apreciação pela comissão mista permanente de senadores e deputados referida no $\S 1^{\circ}$ do art. 166 da Constituição Federal, nos termos do $\S 1^{\circ}$ do art. 72 da Constituição Federal;

V - auditar, por solicitação da comissão mista permanente de senadores e deputados referida no $\S 1^{\circ}$ do art. 166 da Constituição Federal, ou de comissão técnica de qualquer das casas do Congresso Nacional, projetos e programas autorizados na lei orçamentária anual, avaliando os seus resultados quanto à eficácia, eficiência, efetividade e economicidade;

VI - apreciar as contas prestadas anualmente pelo Presidente da República;

VII - acompanhar a arrecadação da receita a cargo da União, das entidades da administração indireta, incluídas as fundações e sociedades instituídas e mantidas pelo poder público federal, e das demais instituições sob sua jurisdição, mediante fiscalizações, ou por meio de demonstrativos próprios;

VIII - apreciar, para fins de registro, a legalidade dos atos de admissão de pessoal, a qualquer título, na administração direta e indireta, incluídas as fundações instituídas e mantidas pelo poder público federal, excetuadas as nomeações para cargo de provimento em comissão, bem como a das concessões de aposentadorias, reformas e pensões a servidores públicos civis e militares federais ou a seus beneficiários, ressalvadas as melhorias posteriores que não alterem o fundamento legal do ato concessório;

IX - efetuar, observada a legislação pertinente, o cálculo das quotas referentes aos fundos de participação a que alude o parágrafo único do art. 161 da Constituição Federal, fiscalizando a entrega dos respectivos recursos;

$X-($ Revogado $)$

XI - efetuar, observada a legislação pertinente, o cálculo das quotas dos recursos provenientes do produto da arrecadação do Imposto sobre Produtos Industrializados destinadas aos estados e ao Distrito Federal, proporcionalmente ao valor das respectivas exportações de produtos industrializados, de que tratam o inciso II do art. 159 e o parágrafo único do art. 161 da Constituição Federal;

XII - emitir, nos termos do $\S 2^{\circ}$ do art. 33 da Constituição Federal, parecer prévio sobre as contas do governo de território federal, no prazo de sessenta dias, a contar de seu recebimento; XIII - fiscalizar, no âmbito de suas atribuições, o cumprimento, por parte dos órgãos e entidades da União, das normas da Lei Complementar $\mathrm{n}^{\circ} 101$, de 4 de maio de 2000 - Lei de Responsabilidade Fiscal;

XIV - processar e julgar as infrações administrativas contra as finanças públicas e a responsabilidade fiscal tipificadas na legislação vigente, com vistas à aplicação de penalidades; XV - acompanhar, fiscalizar e avaliar os processos de desestatização realizados pela administração pública federal, compreendendo as privatizações de empresas, incluindo instituições financeiras, e as concessões, permissões e autorizações de serviço público, nos termos do art. 175 da Constituição Federal e das normas legais pertinentes;

XVI - representar ao Poder competente sobre irregularidades ou abusos apurados, indicando o ato inquinado e definindo responsabilidades, mesmo as de ministro de Estado ou de autoridade de nível hierárquico equivalente;

XVII - aplicar aos responsáveis as sanções e adotar as medidas cautelares previstas neste Regimento;

XVIII - fiscalizar as contas nacionais das empresas supranacionais de cujo capital social a União participe, de forma direta ou indireta, nos termos do tratado constitutivo;

XIX - fiscalizar a aplicação de quaisquer recursos repassados pela União, mediante convênio, acordo, ajuste ou outros instrumentos congêneres, a estado, ao Distrito Federal, a município, e a qualquer outra pessoa, física ou jurídica, pública ou privada; 
XX - acompanhar e fiscalizar, conforme o caso, o cálculo, a entrega e a aplicação de recursos repassados pela União, por determinação legal, a estado, ao Distrito Federal ou a município, conforme dispuser a legislação específica e os respectivos normativos internos;

XXI - assinar prazo para que o órgão ou entidade adote as providências necessárias ao exato cumprimento da lei, se verificada ilegalidade;

XXII - sustar se não atendido, a execução do ato impugnado, comunicando a decisão à Câmara dos Deputados e ao Senado Federal;

XXIII - fiscalizar as declarações de bens e rendas apresentadas pelas autoridades e servidores públicos;

XXIV - decidir sobre denúncia que lhe seja encaminhada por qualquer cidadão, partido político, associação ou sindicato, bem como sobre representações em geral;

XXV - decidir sobre consulta que lhe seja formulada por autoridade competente, a respeito de dúvida suscitada na aplicação de dispositivos legais e regulamentares concernentes a matéria de sua competência;

XXVI - decidir sobre representações relativas a licitações e contratos administrativos e ao descumprimento da obrigatoriedade de que as câmaras municipais, os partidos políticos, os sindicatos de trabalhadores e as entidades empresariais sejam notificados da liberação de recursos federais para os respectivos municípios, nos termos da legislação vigente;

XXVII - fiscalizar a aplicação dos recursos repassados ao Comitê Olímpico Brasileiro e ao Comitê Paraolímpico Brasileiro por força da legislação vigente;

XXVIII - implementar e manter na Internet a página Contas Públicas, na forma definida em ato normativo;

XXIX - realizar outras fiscalizações ou exercer outras atribuições previstas em lei;

XXX - alterar este Regimento;

XXXI - eleger seu Presidente e seu Vice-Presidente, e dar-lhes posse;

XXXII - conceder licença, férias e outros afastamentos aos ministros, ministros-substitutos e membros do Ministério Público junto ao Tribunal, dependendo de inspeção por junta médica a licença para tratamento de saúde por prazo superior a seis meses;

XXXIII - organizar sua Secretaria e prover-lhe os cargos, observada a legislação pertinente;

XXXIV - propor ao Congresso Nacional a criação, transformação e extinção de cargos e funções do quadro de pessoal de sua Secretaria, bem como a fixação da respectiva remuneração. $\S 1^{\circ}$. No julgamento de contas e na fiscalização que lhe compete, o Tribunal decidirá sobre a legalidade, a legitimidade e a economicidade dos atos de gestão e das despesas deles decorrentes, bem como sobre a aplicação de subvenções e a renúncia de receitas.

$\S 2^{\circ}$. Todas as menções a ministro-substituto constantes deste Regimento Interno referem-se ao cargo de que trata o art. $73, \S 4^{\circ}$, da Constituição Federal, cujos titulares, nos termos do texto constitucional, substituem os ministros e exercem as demais atribuições da judicatura, presidindo processos e relatando-os com proposta de decisão, segundo o que dispõe o art. 78, parágrafo único, da Lei ${ }^{\circ} 8.443 / 1992$.

Art. $2^{\circ}$ Ao Tribunal de Contas da União assiste o poder regulamentar, podendo, em consequência, expedir atos normativos sobre matérias de sua competência e sobre a organização dos processos que lhe devam ser submetidos, obrigando ao seu cumprimento aqueles que lhe estão jurisdicionados, sob pena de responsabilidade, nos termos do art. $3^{\circ}$ da Lei $n^{\circ} 8.443$, de 1992.

Art. $3^{\circ}$ No exercício de sua competência, o Tribunal terá irrestrito acesso a todas as fontes de informações disponíveis em órgãos e entidades jurisdicionados, inclusive às armazenadas em meio eletrônico, bem como àquelas que tratem de despesas de caráter sigiloso. 


\section{CAPÍTULO II \\ JURISDIÇÃO}

Art. $4^{\circ} \mathrm{O}$ Tribunal de Contas da União tem jurisdição própria e privativa, em todo o território nacional, sobre as pessoas e matérias sujeitas à sua competência. Art. $5^{\circ}$ A jurisdição do Tribunal abrange:

I - qualquer pessoa física ou jurídica, pública ou privada, que utilize, arrecade, guarde, gerencie ou administre dinheiros, bens e valores públicos ou pelos quais a União responda, ou que, em nome desta, assuma obrigações de natureza pecuniária;

II - aqueles que derem causa a perda, extravio ou outra irregularidade de que resulte dano ao erário;

III - os dirigentes de empresas públicas e sociedades de economia mista constituídas com recursos da União;

IV - os dirigentes ou liquidantes das empresas encampadas ou sob intervenção ou que, de qualquer modo, venham a integrar, provisória ou permanentemente, o patrimônio da União ou de outra entidade federal;

$\mathrm{V}$ - os responsáveis pelas contas nacionais das empresas supranacionais de cujo capital social a União participe, de forma direta ou indireta, nos termos do tratado constitutivo;

VI - os responsáveis por entidades dotadas de personalidade jurídica de direito privado que recebam contribuições parafiscais e prestem serviço de interesse público ou social;

VII - todos aqueles que lhe devam prestar contas ou cujos atos estejam sujeitos à sua fiscalização por expressa disposição de lei;

VIII - os responsáveis pela aplicação de quaisquer recursos repassados pela União, mediante convênio, acordo, ajuste ou outros instrumentos congêneres, a estado, ao Distrito Federal, a município, e a qualquer outra pessoa, física ou jurídica, pública ou privada;

IX - os sucessores dos administradores e responsáveis a que se refere este artigo, até o limite do valor do patrimônio transferido, nos termos do inciso XLV do art. $5^{\circ}$ da Constituição Federal; $\mathrm{X}$ - os representantes da União ou do poder público federal na assembleia geral das empresas estatais e sociedades anônimas de cujo capital as referidas pessoas jurídicas participem, solidariamente com os membros dos conselhos fiscal e de administração, pela prática de atos de gestão ruinosa ou liberalidade à custa das respectivas sociedades.

\section{TÍTULO II \\ ORGANIZAÇÃO \\ CAPÍTULO I \\ SEDE E COMPOSIÇÃO}

Art. $6^{\circ} \mathrm{O}$ Tribunal de Contas da União tem sede no Distrito Federal e compõe-se de nove ministros.

Art. $7^{\circ}$ São órgãos do Tribunal o Plenário, a Primeira e a Segunda câmaras, o Presidente, as comissões, de caráter permanente ou temporário, e a Corregedoria, que colaborarão no desempenho de suas atribuições.

Art. $8^{\circ} \mathrm{O}$ Presidente, em suas ausências e impedimentos, por motivo de licença, férias ou outro afastamento legal, será substituído pelo Vice-Presidente.

$\S 1^{\circ} \mathrm{Na}$ ausência ou impedimento do Vice-Presidente, o Presidente será substituído pelo ministro mais antigo em exercício no cargo. 
$\S 2^{\circ} \mathrm{O}$ Vice-Presidente, em suas ausências e impedimentos, por motivo de licença, férias ou outro afastamento legal, será substituído nas funções de Corregedor pelo ministro mais antigo em exercício no cargo.

Art. $9^{\circ}$ Funciona junto ao Tribunal o Ministério Público, na forma estabelecida nos arts. 58 a 64.

Art. 10. O Tribunal disporá de Secretaria para atender às atividades de apoio técnico e administrativo, na forma estabelecida nos arts. 65 e 66.

\section{CAPÍTULO II COMPOSIÇÃO DAS CÂMARAS}

Art. 11. Cada câmara compõe-se de quatro ministros, indicados pelo Presidente do Tribunal na primeira sessão ordinária de cada ano.

$\S 1^{\circ} \mathrm{O}$ ministro-substituto atua, em caráter permanente, junto à câmara para a qual for designado pelo Presidente do Tribunal.

$\S 2^{\circ}$ Funciona junto a cada câmara um representante do Ministério Público.

$\S 3^{\circ}$ É permitida a permuta ou remoção voluntária de ministros, de uma para outra câmara, com anuência do Plenário, tendo preferência o mais antigo.

Art. 12. As câmaras são presididas pelo Vice-Presidente do Tribunal e pelo ministro mais antigo no exercício do cargo, designados pelo Presidente do Tribunal na primeira sessão ordinária de cada ano.

$\S 1^{\circ} \mathrm{Na}$ hipótese de o Vice-Presidente suceder o Presidente do Tribunal, nos termos da parte final do inciso I do art. 31, assumirá a Presidência da câmara o ministro mais antigo no exercício do cargo, entre os que dela fizerem parte.

$\S 2^{\circ} \mathrm{O}$ Presidente de cada câmara será substituído, em suas ausências e impedimentos, pelo ministro mais antigo no exercício do cargo, entre os que dela fizerem parte.

Art. 13. O Presidente do Tribunal, ao deixar o cargo, passará a integrar a câmara a que pertencia o seu sucessor.

Art. 14. O ministro, ao ser empossado, passa a integrar a câmara onde exista vaga.

\section{CAPÍTULO III COMPETÊNCIA DO PLENÁRIO}

Art. 15. Compete privativamente ao Plenário, dirigido pelo Presidente do Tribunal:

I - deliberar originariamente sobre:

a) o parecer prévio relativo às Contas do Presidente da República;

b) pedido de informação ou solicitação sobre matéria da competência do Tribunal que lhe seja endereçado pelo Congresso Nacional, por qualquer de suas casas, ou por suas comissões;

c) solicitação de pronunciamento formulada pela comissão mista permanente de senadores e deputados referida no $\S 1^{\circ}$ do art. 166 da Constituição Federal, nos termos do $\S 1^{\circ}$ do art. 72 da Constituição Federal;

d) incidente de uniformização de jurisprudência, na forma do art. 91;

e) conflito de lei ou de ato normativo do poder público com a Constituição Federal, em matéria da competência do Tribunal;

f) fixação dos coeficientes destinados ao cálculo das parcelas a serem entregues aos estados, Distrito Federal e municípios, à conta dos recursos do Fundo de Participação dos Estados e do Distrito Federal (FPE) e do Fundo de Participação dos Municípios (FPM), a que alude o 
parágrafo único do art. 161 da Constituição Federal, observados os critérios estabelecidos nas normas legais e regulamentares pertinentes;

g) fixação dos coeficientes destinados ao cálculo das parcelas que deverão ser entregues aos estados e ao Distrito Federal, sobre o produto da arrecadação do imposto sobre produtos industrializados, de que trata o inciso II do art. 159 da Constituição Federal, observados os critérios estabelecidos nas normas legais e regulamentares pertinentes;

h) contestação mencionada no art. 292;

i) inabilitação de responsável e inidoneidade de licitante, nos termos dos arts. 270 e 271, e adoção das medidas cautelares previstas nos arts. 273 a 276, resguardada, no caso do último artigo, a possibilidade de antecipação da medida pelo relator ou pelo Presidente;

j) realização de fiscalizações em unidades do Poder Legislativo, do Supremo Tribunal Federal, dos Tribunais Superiores, da Presidência da República, do Tribunal de Contas da União, do Conselho Nacional de Justiça, do Conselho Nacional do Ministério Público, bem como do Ministério Público da União e da Advocacia-Geral da União;

1) representação de equipe de fiscalização prevista no art. 246;

m) relatório de auditoria operacional;

n) relatório de fiscalização realizada em virtude de solicitação do Congresso Nacional, de suas casas e das respectivas comissões, bem como daquela autorizada nos termos da alínea "j" do inciso I do art. 15;

o) consulta sobre matéria da competência do Tribunal;

p) denúncia;

q) matéria regimental ou de caráter normativo;

r) conflito de competência entre relatores;

s) qualquer assunto não incluído expressamente na competência das câmaras;

II - deliberar sobre os recursos de reconsideração, os embargos de declaração e os pedidos de reexame apresentados contra suas próprias decisões, bem como os agravos interpostos a despachos decisórios proferidos em processos de sua competência;

III - deliberar sobre recursos de revisão;

IV - deliberar sobre os recursos contra decisões adotadas pelo Presidente sobre matéria administrativa;

V - aprovar proposta de acordo de cooperação e instrumento congênere, nas situações em que houver transferência de recursos financeiros;

VI - aprovar o plano de controle externo;

VII - aprovar os enunciados da Súmula da Jurisprudência do Tribunal;

VIII - aprovar proposta relativa a projeto de lei que o Tribunal deva encaminhar ao Poder Legislativo;

IX - deliberar sobre a lista tríplice dos ministros-substitutos e dos membros do Ministério Público junto ao Tribunal, para preenchimento de cargo de ministro.

Art. 16. Compete ainda ao Plenário:

I - constituir comissões temporárias, sem prejuízo do disposto no inciso XLI do art. 28;

II - apreciar questões administrativas de caráter relevante;

III - deliberar sobre processos por ele avocados em razão de sua relevância, por sugestão de ministro ou de ministro-substituto convocado submetida ao colegiado;

IV - deliberar sobre processos remetidos pelo relator ou pelas câmaras, nos termos do $\S 1^{\circ}$ do art. 17 ou do art. 139, exceto os de que trata o inciso VII do art. 17.

V - deliberar sobre propostas de fixação de entendimento de especial relevância para a Administração Pública, sobre questão de direito, que somente poderão ser aprovadas por $2 / 3$ dos ministros, inclusive ministros-substitutos convocados. 
VI - deliberar sobre propostas de determinações de caráter normativo, de estudos sobre procedimentos técnicos, bem como daqueles em que se entender necessário o exame incidental de inconstitucionalidade de lei ou de ato normativo do poder público.

\section{CAPÍTULO IV COMPETÊNCIA DAS CÂMARAS}

Art. 17. Compete à Primeira e à Segunda câmaras deliberar sobre:

I - prestação e tomada de contas, inclusive especial;

II - ato de admissão de pessoal da administração direta e indireta, incluídas as fundações instituídas e mantidas pelo poder público federal;

III - a legalidade, para fins de registro, de concessão de aposentadoria, reforma ou pensão a servidor público e a militar federal ou a seus beneficiários;

IV - representação, exceto a de que trata a alínea 1 do inciso I do art. 15;

V - realização de inspeção, ressalvado o disposto na alínea j do inciso I do art. 15;

VI - relatório de fiscalização, exceto as de que tratam as alíneas "j", "l", "m" e "n", do inciso I do art. 15;

VII - pedido de reexame, recurso de reconsideração e embargos de declaração apresentados contra suas próprias deliberações, bem como agravo interposto a despacho decisório proferido em processo de sua competência.

$\S 1^{\circ}$ Os assuntos de competência das câmaras, exceto os previstos no inciso VII, poderão ser incluídos na pauta do Plenário pelo relator, ou por deliberação da câmara acolhendo proposta de ministro ou sugestão de ministro-substituto ou do representante do Ministério Público, sempre que a relevância da matéria recomende esse procedimento.

$\S 2^{\circ}$ Não poderão ser apreciados pelas câmaras os processos que contenham propostas de fixação de entendimento sobre questão de direito em determinada matéria, de determinações em caráter normativo e de estudos sobre procedimentos técnicos, bem como aqueles em que se entender necessário o exame incidental de inconstitucionalidade de lei ou de ato normativo do poder público.

$\S 3^{\circ}$ Realizado, pelo Plenário, o exame incidental de inconstitucionalidade indicado na parte final do parágrafo anterior, o processo retornará à Câmara para continuidade do feito, sem prejuízo do disposto no $\S 1^{\circ}$.

$\S 4^{\circ}$ Deverão ser remetidos para apreciação do Plenário os processos nos quais se entenda cabível, em grau de recurso, o exame de declaração de inidoneidade de licitante ou de inabilitação de responsável para o exercício de cargo em comissão ou função de confiança no âmbito da administração pública federal.

\section{CAPÍTULO V \\ COMPOSIÇÃO E COMPETÊNCIA DAS COMISSÕES}

Art. 18. As comissões que colaboram no desempenho das atribuições do Tribunal são permanentes ou temporárias.

Parágrafo único. São permanentes as comissões de Regimento e de Jurisprudência.

Art. 19. As comissões permanentes compõem-se de três membros efetivos e um suplente, designados pelo Presidente, entre ministros e ministros-substitutos, do Tribunal, na primeira sessão ordinária de seu mandato.

$\S 1^{\circ}$ As comissões permanentes funcionarão com a presença de, no mínimo, dois membros. $\S 2^{\circ}$ Integrará a Comissão de Regimento o ministro mais antigo no exercício do cargo. 
$\S 3^{\circ} \mathrm{Na}$ composição das comissões de Regimento e de Jurisprudência será assegurada a participação de ministros das duas câmaras.

$\S 4^{\circ} \mathrm{O}$ ministro integrante de comissão permanente será substituído, naquela atividade,

preferencialmente pelo suplente, ou, na ausência deste, por ministro-substituto convocado.

Art. 20. As comissões temporárias compõem-se de dois ou mais membros, entre ministros e ministros-substitutos, indicados pelo Presidente no ato de sua constituição.

Art. 21. Cada comissão será presidida pelo ministro mais antigo de seus integrantes.

Art. 22. São atribuições da Comissão de Regimento:

I - cuidar da atualização do Regimento Interno, mediante a apresentação de projetos de alteração do texto em vigor e a emissão de parecer sobre projeto apresentado por ministro ou sugestão oferecida por ministro-substituto ou representante do Ministério Público;

II - opinar em processo administrativo, quando consultada pelo Presidente;

III - elaborar e aprovar suas normas de serviço.

Art. 23. São atribuições da Comissão de Jurisprudência:

I - manter a atualização e a publicação da Súmula da Jurisprudência do Tribunal;

II - superintender os serviços de sistematização e divulgação da jurisprudência predominante do Tribunal, sugerindo medidas que facilitem a pesquisa de julgados ou processos;

III - propor ao colegiado que seja compendiada em súmula a jurisprudência do Tribunal, quando verificar que o Plenário e as câmaras não divergem em suas decisões sobre determinada matéria;

IV - elaborar e aprovar suas normas de serviço.

\section{CAPÍTULO VI \\ ELEIÇÃO DO PRESIDENTE E DO VICE-PRESIDENTE}

Art. 24. O Presidente e o Vice-Presidente do Tribunal de Contas da União serão eleitos, por seus pares, para um mandato de um ano civil, permitida a reeleição apenas por um período.

$\S 1^{\circ}$ A eleição realizar-se-á em escrutínio secreto, na última sessão ordinária do mês de dezembro, ou, no caso de vaga eventual, na primeira sessão ordinária após a sua ocorrência.

$\S 2^{\circ}$ Não se procederá a nova eleição se ocorrer vaga dentro dos sessenta dias anteriores ao término do mandato.

$\S 3^{\circ} \mathrm{O}$ quórum para eleição será de, pelo menos, cinco ministros, incluindo o que presidir o ato. $\S 4^{\circ}$ Não havendo quórum, será convocada sessão extraordinária para o dia útil seguinte, na forma prevista no art. 98, repetindo-se idêntico procedimento, se necessário.

$\S 5^{\circ}$ Somente os ministros, ainda que no gozo de licença, férias ou outro afastamento legal, podem participar da eleição.

$\S 6^{\circ}$ A eleição do Presidente precederá a do Vice-Presidente.

$\S 7^{\circ}$ A eleição será efetuada pelo sistema de cédula única, obedecidas as seguintes regras:

I - o ministro que estiver presidindo a sessão chamará, na ordem de antiguidade, os ministros, que colocarão na urna os seus votos, contidos em invólucros fechados;

II - o ministro que não comparecer à sessão poderá enviar à Presidência o seu voto, em sobrecarta fechada, onde será declarada a sua destinação;

III - as sobrecartas contendo os votos dos ministros ausentes serão depositadas na urna, pelo Presidente, sem quebra de sigilo;

IV - considerar-se-á eleito, em primeiro escrutínio, o ministro que obtiver os votos de mais da metade dos membros do Tribunal; 
V - concorrerão em segundo escrutínio somente os dois ministros mais votados no primeiro e proclamar-se-á eleito, entre os dois, o mais votado, ou, se ocorrer empate, o mais antigo no cargo.

Art. 25. O escolhido para a vaga que ocorrer antes do término do mandato será empossado na mesma sessão em que for eleito e exercerá o cargo de Presidente ou de Vice-Presidente, conforme o caso, no período restante.

Art. 26. A posse do Presidente e do Vice-Presidente do Tribunal, eleitos para entrarem em exercício a partir de $1^{\circ}$ de janeiro do ano seguinte ao da eleição, será dada em sessão extraordinária a ser

realizada até 16 de dezembro.

$\S 1^{\circ}$ No ato de posse, o Presidente e o Vice-Presidente prestarão o seguinte compromisso:

"PROMETO DESEMPENHAR COM INDEPENDÊNCIA E EXAÇÃO OS DEVERES DO MEU CARGO, CUMPRINDO E FAZENDO CUMPRIR A CONSTITUIÇÃO FEDERAL E AS LEIS DO PAÍS".

$\S 2^{\circ}$ Em caso de licença ou outro afastamento legal, a posse poderá ocorrer mediante procuração específica, devendo o empossado firmar o compromisso por escrito.

Art. 27. Serão lavrados pelo dirigente da unidade responsável pelo secretariado das sessões, em livro próprio, os termos de posse do Presidente e do Vice-Presidente.

\section{CAPÍTULO VII COMPETÊNCIA DO PRESIDENTE}

Art. 28. Compete ao Presidente:

I - dirigir os trabalhos e superintender a ordem e a disciplina do Tribunal e de sua Secretaria; II - representar o Tribunal perante os Poderes da União, dos estados e municípios, e demais autoridades;

III - atender ao pedido de informação, nos limites de sua competência, dando ciência ao Tribunal, se for o caso;

IV - atender ao pedido de informação decorrente de decisão do Tribunal ou de iniciativa de ministro sobre questão administrativa;

V - velar pelas prerrogativas do Tribunal, cumprindo e fazendo cumprir a sua Lei Orgânica e este Regimento Interno;

VI - presidir as sessões plenárias;

VII - convocar sessão extraordinária do Plenário, observado o disposto no art. 98;

VIII - apresentar ao Plenário as questões de ordem e resolver os requerimentos que lhe sejam formulados, sem prejuízo de recurso ao Plenário;

IX - proferir voto de desempate em processo submetido ao Plenário;

$\mathrm{X}$ - votar quando se apreciar inconstitucionalidade de lei ou de ato do poder público;

$\mathrm{XI}$ - votar quando se apreciarem processos que envolvam matéria administrativa e projetos de atos normativos;

XII - relatar e votar quando se apreciar agravo contra despacho decisório de sua autoria;

XIII - dar ciência ao Plenário dos expedientes de interesse geral recebidos dos Poderes da União ou de quaisquer outras entidades;

XIV - decidir as questões administrativas ou, quando considerá-las relevantes, sortear relator para submetê-las ao Plenário, segundo o inciso IV do art. 154, resguardados os casos de que tratam os

arts. 47 e 74 e a competência da Corregedoria; 
$\mathrm{XV}$ - submeter ao Plenário a proposta relativa a projeto de lei que o Tribunal deva encaminhar ao Poder Legislativo;

XVI - despachar os processos e documentos urgentes e determinar a realização de inspeção na hipótese de afastamento legal do relator no período de recesso;

XVII - decidir sobre pedidos de vista e de cópia de peça de processo formulados pelas partes interessadas, nas hipóteses dos $\S \S 1^{\circ}$ e $3^{\circ}$ do art. 163;

XVIII - cumprir e fazer cumprir as deliberações do Plenário;

XIX - decidir sobre pedido de sustentação oral relativo a processo a ser submetido ao Plenário, na forma estabelecida no art. 168;

$\mathrm{XX}$ - expedir certidões requeridas ao Tribunal na forma da lei;

XXI - dar posse a ministro, ministro-substituto e ao procurador-geral;

XXII - designar os presidentes das câmaras, na forma estabelecida no art. 12;

XXIII - expedir atos concernentes às relações jurídico-funcionais dos ministros, ministrossubstitutos e membros do Ministério Público;

XXIV - definir a composição das câmaras, observado o disposto noß $3^{\circ}$ do art. 55 e nos arts. 11 a 14

XXV - designar os ministros-substitutos para atuarem, em caráter permanente, junto às câmaras, na forma estabelecida noß $1^{\circ}$ do art. 11;

XXVI - convocar ministro-substituto para substituir ministro, na forma estabelecida nos incisos I e II do art. 55;

XXVII - elaborar a lista tríplice segundo o critério de antiguidade dos ministros-substitutos, na forma estabelecida no $\$ 3^{\circ}$ do art. 36;

XXVIII - coordenar a organização das listas de unidades jurisdicionadas, nos termos do parágrafo único do art. 148;

XXIX - submeter ao Plenário projeto de ato normativo fixando o valor de que trata o caput do art. 199, nos termos doß $1^{\circ}$ do mesmo artigo;

XXX - proceder à distribuição dos processos, mediante sorteio, nos termos dos arts. 147 a 155; XXXI - assinar as deliberações do Plenário;

XXXII - aprovar as atas do Plenário, submetendo o ato para homologação na sessão ordinária subsequente;

XXXIII - efetuar as nomeações para cargos efetivos e em comissão e as designações para funções de confiança no quadro de pessoal da Secretaria do Tribunal, bem como as exonerações

$\mathrm{e}$

dispensas;

XXXIV - administrar os recursos humanos, materiais, tecnológicos, orçamentários e financeiros do Tribunal;

XXXV - conceder aposentadoria a servidores do Tribunal, bem como pensão a seus beneficiários;

XXXVI - determinar, na forma prevista no art. 43, o início do processo de verificação de invalidez de ministro ou ministro-substituto;

XXXVII - nomear curador ao paciente, na hipótese do inciso anterior, quando se tratar de incapacidade mental, bem assim praticar os demais atos preparatórios do procedimento;

XXXVIII - determinar a instauração de sindicância ou processo administrativo disciplinar e aplicar as penalidades de demissão e de cassação de aposentadoria ou disponibilidade de servidor do Tribunal;

XXXIX - aprovar, anualmente, a programação financeira de desembolso do Tribunal;

XL - assinar os acordos de cooperação de que trata o art. 296; 
XLI - criar comissões temporárias e designar os seus membros e ainda os das comissões permanentes;

XLII - apresentar ao Plenário, até 31 de março do ano subsequente, o relatório de sua gestão, com os dados fornecidos até 31 de janeiro pelas unidades da Secretaria do Tribunal;

XLIII - aprovar e fazer publicar o Relatório de Gestão Fiscal exigido pela Lei Complementar $\mathrm{n}^{\mathrm{o}} 101$, de 4 de maio de 2000.

XLIV - designar, na primeira sessão ordinária de cada ano, permitida a recondução, o ministro responsável por supervisionar a edição da Revista do Tribunal.

$\S 1^{\circ} \mathrm{O}$ Presidente poderá delegar as atribuições previstas nos incisos XIV, XVII, XX, XXIII, XXX, XXXIII a XXXV e XL.

$\S 2^{\circ}$ Compete, ainda, ao Presidente, assinar a "Carteira de Identificação Funcional" dos servidores habilitados a exercerem funções específicas de controle externo no Tribunal de Contas da União, no exercício de cargo efetivo ou em comissão.

Art. 29. Em caráter excepcional e havendo urgência, o Presidente poderá decidir sobre matéria da competência do Tribunal, submetendo o ato à homologação do Plenário na próxima sessão ordinária.

Art. 30. Dos atos e das decisões administrativas do Presidente caberá recurso ao Plenário.

Parágrafo único. O recurso administrativo de que trata o caput será regulado, no que couber, pela Lei Geral do Processo Administrativo.

\section{CAPÍTULO VIII \\ COMPETÊNCIA DO VICE-PRESIDENTE}

Art. 31. Compete ao Vice-Presidente:

I - substituir o Presidente em suas ausências e impedimentos por motivo de licença, férias ou outro afastamento legal, e sucedê-lo, no caso de vaga, na hipótese prevista noß $2^{\circ}$ do art. 24;

II - presidir uma das câmaras;

III - exercer as funções de Corregedor;

IV - (Revogado)

V - colaborar com o Presidente no exercício de suas funções, quando solicitado.

Art. 32. Incumbe ao Vice-Presidente, no exercício das funções de Corregedor:

I - exercer os encargos de inspeção e correição geral permanentes;

II - relatar os processos administrativos referentes a deveres dos ministros e ministrossubstitutos do Tribunal e dos servidores da Secretaria;

III - auxiliar o Presidente nas funções de fiscalização e supervisão da ordem e da disciplina do Tribunal e de sua Secretaria;

IV - apresentar ao Plenário, até a última sessão do mês de fevereiro do ano subsequente, relatório das atividades da Corregedoria.

\section{CAPÍTULO IX \\ COMPETÊNCIA DO PRESIDENTE DE CÂMARA}

Art. 33. Ao Presidente de câmara compete:

I - presidir as sessões;

II - convocar sessões extraordinárias;

III - relatar os processos que lhe forem distribuídos;

IV - proferir voto nos processos submetidos à deliberação da respectiva câmara; 
$\mathrm{V}$ - apresentar ao colegiado as questões de ordem e resolver os requerimentos que lhe sejam formulados, sem prejuízo de recurso para a respectiva câmara;

VI - encaminhar ao Presidente do Tribunal os assuntos da atribuição deste, bem como as matérias da competência do Plenário;

VII - convocar ministro-substituto para substituir ministro, na forma estabelecida no inciso II do art. 55;

VIII - decidir sobre pedido de sustentação oral relativo a processo a ser submetido à respectiva câmara, na forma estabelecida no art. 168;

IX - assinar as deliberações da câmara, observado o disposto no art. 68;

$\mathrm{X}$ - aprovar as atas da câmara, submetendo o ato para homologação na próxima sessão ordinária;

XI - cumprir e fazer cumprir as deliberações da câmara.

\section{CAPÍTULO X MINISTROS}

Art. 34. Os ministros do Tribunal de Contas da União, em número de nove, serão nomeados pelo Presidente da República, observados os requisitos constitucionais e escolhidos:

I - um terço pelo Presidente da República, com aprovação do Senado Federal, sendo dois alternadamente entre ministros-substitutos e membros do Ministério Público junto ao Tribunal, indicados em lista tríplice pelo Plenário, segundo os critérios de antiguidade e merecimento, na forma estabelecida no art. 36;

II - dois terços pelo Congresso Nacional.

Art. 35. Em caso de vacância, a competência para a escolha de ministro do Tribunal de Contas da União será definida de modo que mantenha a composição mencionada no artigo anterior.

Art. 36. Ocorrendo vaga de cargo de ministro a ser provida por ministro-substituto ou por membro do Ministério Público junto ao Tribunal, o Presidente convocará sessão extraordinária para que o Plenário delibere sobre a respectiva lista tríplice, dentro do prazo de quinze dias, contado da data da ocorrência da vaga.

$\S 1^{\circ} \mathrm{O}$ quórum para deliberar sobre a lista a que se refere o caput será de, pelo menos, cinco ministros, incluindo o que presidir o ato.

$\S 2^{\circ}$ A lista tríplice obedecerá, alternadamente, ao critério de antiguidade e de merecimento.

$\S 3^{\circ}$ Quando o preenchimento da vaga deva obedecer ao critério de antiguidade, caberá ao Presidente elaborar a lista tríplice, no caso de vaga a ser provida por ministro-substituto, e, ao Procurador-Geral, se o provimento for destinado a membro do Ministério Público, a ser submetida ao Plenário.

$\S 4^{\circ}$ No caso de vaga a ser preenchida segundo o critério de merecimento, o Presidente apresentará ao Plenário, conforme o caso, a lista dos nomes dos ministros-substitutos ou dos membros do Ministério Público que possuam os requisitos constitucionais, cabendo ao Procurador-Geral elaborar lista sêxtupla para os fins de formação da lista tríplice pelo Tribunal. $\S 5^{\circ}$ Cada ministro escolherá três nomes, se houver, de ministros-substitutos ou de membros do Ministério Público.

$\S 6^{\circ} \mathrm{O}$ Presidente chamará, na ordem de antiguidade, os ministros, que colocarão na urna os votos contidos em invólucro fechado.

$\S 7^{\circ}$ Os três nomes mais votados, se houver, constarão da lista tríplice a ser encaminhada ao Presidente da República. 
Art. 37. Os ministros têm prazo de trinta dias, a partir da publicação do ato de nomeação no Diário Oficial da União, prorrogável por mais sessenta dias, no máximo, mediante solicitação escrita, para posse e exercício no cargo.

Art. 38. Os ministros tomam posse em sessão extraordinária do Plenário, podendo fazê-lo perante o Presidente, em período de recesso.

$\S 1^{\circ}$ No ato de posse, o ministro prestará compromisso em termos idênticos aos constantes doß $1^{\circ}$ do art. 26.

$\S 2^{\circ}$ Será lavrado pelo dirigente da unidade administrativa competente da Secretaria do Tribunal, em livro próprio, o termo de posse do ministro.

Art. 39. É vedado ao ministro do Tribunal:

I - exercer, ainda que em disponibilidade, outro cargo ou função, salvo uma de magistério;

II - exercer cargo técnico ou de direção de sociedade civil, associação ou fundação, de qualquer natureza ou finalidade, salvo de associação de classe, sem remuneração;

III - exercer comissão remunerada ou não, mesmo em órgãos de controle da administração pública direta ou indireta, ou em concessionárias de serviço público;

IV - exercer profissão liberal, emprego particular ou comércio, ou participar de sociedade comercial, exceto como acionista ou cotista sem ingerência;

$\mathrm{V}$ - celebrar contrato com pessoa jurídica de direito público, empresa pública, sociedade de economia mista, fundação, sociedade instituída e mantida pelo poder público ou empresa concessionária de serviço público, salvo quando o contrato obedecer a normas uniformes para todo e qualquer contratante;

VI - dedicar-se a atividade político-partidária;

VII - manifestar, por qualquer meio de comunicação, opinião sobre processo pendente de julgamento, seu ou de outrem, ou emitir juízo depreciativo sobre despachos, votos ou sentenças de órgãos judiciais, ressalvada a crítica nos autos e em obras técnicas ou no exercício de magistério;

VIII - atuar em processo de interesse próprio, de cônjuge, de parente consanguíneo ou afim, na linha reta ou na colateral, até o segundo grau, ou de amigo íntimo ou inimigo capital, assim como em processo em que tenha funcionado como advogado, perito, representante do Ministério Público ou servidor da Secretaria do Tribunal ou do Controle Interno.

IX - atuar em processo quando nele estiver postulando, como advogado da parte, o seu cônjuge ou qualquer parente seu, consanguíneo ou afim, em linha reta ou colateral, até o segundo grau. $\S 1^{\circ}$ No caso do inciso IX, o impedimento só se verifica quando o advogado já estava exercendo o patrocínio da causa; é, porém, vedado ao advogado pleitear no processo, a fim de criar o impedimento do ministro.

Art. 40. Não podem ocupar, simultaneamente, cargos de ministro, parentes consanguíneos ou afins, na linha reta ou na colateral, até o segundo grau.

Parágrafo único. A incompatibilidade resolve-se:

I - antes da posse, contra o último nomeado ou contra o mais moço, se nomeados na mesma data;

II - depois da posse, contra o que lhe deu causa;

III - se a ambos imputável, contra o que tiver menos tempo de exercício no Tribunal.

Art. 41. A antiguidade do ministro será determinada na seguinte ordem:

I - pela posse;

II - pela nomeação;

III - pela idade.

Art. 42. Os ministros, após um ano de exercício, terão direito a sessenta dias de férias por ano, observada a escala aprovada pelo Presidente e comunicada ao Plenário no mês de dezembro. 
$\S 1^{\circ}$ As férias dos ministros serão concedidas de forma que não comprometam o quórum das sessões.

$\S 2^{\circ}$ A qualquer tempo, por necessidade do serviço, as férias poderão ser interrompidas, sendo facultado ao interessado gozar o restante do período em época oportuna.

Art. 43. O processo de verificação de invalidez de ministro, para o fim de aposentadoria, terá início a seu requerimento, ou por ordem do Presidente do Tribunal, de ofício, ou em cumprimento de deliberação do Tribunal.

$\S 1^{\circ}$ Instaurado o processo de verificação de invalidez, o paciente será afastado, desde logo, do exercício do cargo, até decisão final, devendo ficar concluído o processo no prazo de sessenta dias.

$\S 2^{\circ}$ Tratando-se de incapacidade mental, o Presidente nomeará curador ao paciente, sem prejuízo da defesa que este queira oferecer pessoalmente, ou por procurador que constituir.

$\S 3^{\circ} \mathrm{O}$ ministro que, por dois anos consecutivos, afastar-se, ao todo, por seis meses ou mais, para tratamento de saúde, deverá submeter-se, ao requerer nova licença para igual fim, dentro de dois anos, a exame para verificação de invalidez.

Art. 44. O paciente será notificado, por ofício do Presidente do Tribunal, ao qual será anexada cópia da ordem inicial, para alegar, em dez dias, prorrogáveis por mais dez, o que entender a bem de seus direitos, mesmo mediante a juntada de documentos.

Art. 45. Decorrido o prazo previsto no artigo antecedente, atendida ou não a notificação, o Presidente nomeará uma junta de três médicos para proceder ao exame do paciente e ordenará as demais diligências necessárias à averiguação do caso.

Parágrafo único. A recusa do paciente em submeter-se à perícia médica permitirá o julgamento baseado em quaisquer outras provas.

Art. 46. Concluídas as diligências, poderá o paciente, ou o seu curador, apresentar alegação no prazo de dez dias.

Art. 47. O processo será instruído pela unidade administrativa competente da Secretaria do Tribunal e conduzido pelo Presidente até que seja sorteado o relator.

Art. 48. O julgamento será feito pelo Plenário, participando o Presidente da votação.

Art. 49. A decisão do Tribunal, pela incapacidade do ministro, será tomada pelo voto da maioria absoluta dos seus membros.

Parágrafo único. A decisão que concluir pela incapacidade do ministro será imediatamente comunicada ao Poder Executivo, para os devidos fins.

Art. 50. O Tribunal poderá determinar, por motivo de interesse público, a disponibilidade ou a aposentadoria de ministro da Corte, assegurada a ampla defesa.

$\S 1^{\circ}$ Em qualquer dos casos, antes da instauração do procedimento, o Presidente do Tribunal remeterá ao ministro implicado cópia dos elementos contra ele coligidos, franqueando ao acusado oportunidade para apresentação de defesa prévia, no prazo de quinze dias, contado a partir da notificação.

$\S 2^{\circ}$ Findo o prazo estabelecido para oferecimento de defesa prévia, tenha esta sido ou não apresentada, o Presidente convocará o Tribunal para, em sessão ordinária ou extraordinária, ouvido o Ministro-Corregedor, deliberar a respeito da instauração do processo.

$\S 3^{\circ}$ Determinada a instauração do procedimento, será procedida à distribuição do feito, mediante sorteio de relator.

$\S 4^{\circ}$ A partir da instauração do procedimento, o Tribunal poderá, a qualquer tempo, afastar o ministro implicado do exercício de suas funções, sem prejuízo dos vencimentos e das vantagens do cargo, até a deliberação final.

$\S 5^{\circ}$ Finda a fase de instrução do processo, será aberto novo prazo de quinze dias para apresentação de defesa e igual prazo para manifestação do Ministério Público junto ao Tribunal. 
$\S 6^{\circ} \mathrm{O}$ julgamento será realizado em sessão ordinária ou extraordinária, sendo que a disponibilidade ou a aposentadoria somente poderá ser determinada mediante o voto da maioria absoluta dos ministros efetivos do Tribunal, excluído o ministro processado.

$\S 7^{\circ} \mathrm{O}$ Presidente participará da votação de que trata o parágrafo anterior.

$\S 8^{\circ}$ Da decisão publicar-se-á o acórdão.

$\S 9^{\circ} \mathrm{Se}$ a decisão concluir pela disponibilidade ou aposentadoria do ministro, será comunicada, imediatamente, ao Poder Executivo para a formalização do ato.

$\S 10$ A aposentadoria voluntária do ministro implicado, publicada em data anterior ao julgamento de que trata o§ $6^{\circ}$, implicará o imediato arquivamento do feito.

$\S 11$ Aplicam-se aos Ministros-Substitutos o disposto no presente artigo.

\section{CAPÍTULO XI \\ MINISTROS-SUBSTITUTOS}

Art. 51. Os ministros-substitutos serão nomeados pelo Presidente da República, entre cidadãos que satisfaçam os requisitos exigidos para o cargo de ministro do Tribunal de Contas da União, mediante concurso público de provas e títulos realizado perante o Tribunal e por este homologado, observada a ordem de classificação.

Parágrafo único. A comprovação do efetivo exercício por mais de dez anos de cargo da carreira de controle externo do quadro de pessoal da Secretaria do Tribunal constitui título computável para efeito do concurso a que se refere o caput.

Art. 52. O ministro-substituto, depois de empossado, só perderá o cargo por sentença judicial transitada em julgado.

Art. 53. O ministro-substituto, quando em substituição a ministro, terá as mesmas garantias, impedimentos e subsídio do titular, e gozará, no Plenário e na câmara em que estiver atuando, dos direitos e prerrogativas a este assegurados, nos termos e hipóteses previstos neste Regimento Interno.

Parágrafo único. Quando no exercício regular das demais atribuições da judicatura, o ministrosubstituto terá as mesmas garantias e impedimentos de juiz do Tribunal Regional Federal.

Art. 54. Por todo o período em que o ministro se mantiver afastado do exercício do cargo, o ministro-substituto permanecerá convocado, sendo-lhe asseguradas as vantagens da substituição durante suas ausências justificadas e impedimentos por motivo de licença.

Parágrafo único. Cessará a convocação do ministro-substituto se este entrar em gozo de férias. Art. 55. Incumbe ao ministro-substituto:

I - mediante convocação do Presidente do Tribunal e na forma disciplinada em Resolução específica:

a) exercer, no caso de vacância, as funções relativas ao cargo de ministro, até novo provimento, observada a ordem de preferência;

b) substituir, observada a ordem de preferência, os ministros em suas ausências e impedimentos por motivo de licença, férias ou outro afastamento legal;

II - mediante convocação do Presidente do Tribunal ou de presidente de câmara, conforme o caso:

a) substituir, observada a ordem de preferência, os ministros para efeito de quórum ou para completar a composição do Plenário ou das câmaras, sempre que estes comunicarem ao Presidente do Tribunal ou da câmara respectiva a impossibilidade de comparecimento à sessão; b) votar, se necessário para manter o quórum, no lugar do ministro que declarar impedimento em processo constante da pauta, bem como para desempatar votação, quando aplicável a solução do§ $2^{\circ}$ do art. 124, observada sempre a ordem de preferência; 
III - atuar, em caráter permanente, junto ao Plenário e à câmara para a qual for designado, presidindo a instrução dos processos que lhe forem distribuídos na forma estabelecida nos arts. 147 a 151 e 153, e relatando-os com proposta de acórdão por escrito, a ser votada pelos membros do respectivo colegiado.

$\S 1^{\circ}$ Quando for convocado para substituir ministro em câmara na qual não atue ordinariamente, o ministro-substituto poderá comparecer à sessão da câmara de origem, para relatar, sem direito a voto, os processos de sua relatoria originária já incluídos em pauta ou que sejam de competência privativa desse colegiado.

$\S 2^{\circ}$ Cessada a convocação, o ministro-substituto que estava convocado para substituir ministro em câmara na qual não atue ordinariamente poderá comparecer à sessão desse colegiado pararelatar, sem direito a voto, os processos de sua relatoria originária já incluídos em pauta.

$\S 3^{\circ} \mathrm{Na}$ impossibilidade de convocação de ministros-substitutos, os ministros poderão atuar em outra câmara de que não sejam membros efetivos, mediante designação do Presidente do Tribunal por solicitação de presidente de câmara.

$\S 4^{\circ}$ A preferência dos ministros-substitutos será determinada, sucessivamente, pela antiguidade da posse, da nomeação e pela classificação no concurso público de ingresso na carreira.

$\S 5^{\circ}$ Quando convocados, os ministros-substitutos deverão atuar, prioritariamente, nos processos da relatoria do ministro substituído.

$\S 6^{\circ}$ Em caso de não cumprimento, por motivo de força maior, do disposto no parágrafo anterior, é facultado ao Presidente convocar, observada a ordem de preferência, novo ministro-substituto para substituir ministro, devendo ser tornada sem efeito a primeira convocação.

Art. 56. Os ministros-substitutos não poderão exercer funções ou comissões na Secretaria do Tribunal.

Art. 57. Aplica-se aos ministros-substitutos o disposto nos arts. 37, 39 e 43 a 50.

Parágrafo único. O disposto no art. 42 também é válido para os ministros-substitutos, ressalvado que não poderão coincidir as férias dos que atuarem na mesma câmara.

\section{CAPÍTULO XII MINISTÉRIO PÚBLICO}

Art. 58. O Ministério Público junto ao Tribunal de Contas da União, ao qual se aplicam os princípios institucionais da unidade, da indivisibilidade e da independência funcional, compõese de um procurador-geral, três subprocuradores-gerais e quatro procuradores, nomeados pelo Presidente da República, entre brasileiros, bacharéis em Direito.

$\S 1^{\circ} \mathrm{O}$ Ministério Público junto ao Tribunal tem por Chefe o Procurador-Geral, que será nomeado pelo Presidente da República, entre integrantes da carreira, para exercer mandato de dois anos, permitida a recondução, tendo tratamento protocolar, direitos e prerrogativas correspondentes aos de cargo de ministro do Tribunal.

$\S 2^{\circ}$ Em caso de vacância do cargo de procurador-Geral, o Presidente do Tribunal encaminhará ao Presidente da República lista contendo o nome de todos os integrantes da carreira do Ministério Público, por ordem de antiguidade e com a indicação dos seus respectivos cargos.

$\S 3^{\circ}$ A carreira do Ministério Público junto ao Tribunal é constituída pelos cargos de subprocurador-geral e procurador, este inicial e aquele representando o último nível da carreira, não excedendo a dez por cento a diferença de subsídio de uma classe para outra, respeitada igual diferença entre os cargos de subprocurador-Geral e procurador-geral.

$\S 4^{\circ} \mathrm{O}$ ingresso na carreira far-se-á no cargo de procurador, mediante concurso público de provas e títulos, assegurada a participação da Ordem dos Advogados do Brasil em sua realização e observada, nas nomeações, a ordem de classificação. 
$\S 5^{\circ}$ A promoção ao cargo de subprocurador-Geral far-se-á, alternadamente, por antiguidade e merecimento.

$\S 6^{\circ}$ Caberá ao Procurador-Geral baixar o edital do concurso de que trata o§ $4^{\circ}$, bem assim homologar seu resultado final.

Art. 59. O Procurador-Geral toma posse em sessão extraordinária do Tribunal, podendo fazêlo perante o Presidente, em período de recesso.

$\S 1^{\circ}$ Os demais membros do Ministério Público tomam posse perante o Procurador-Geral.

$\S 2^{\circ}$ Será lavrado pelo dirigente da unidade administrativa competente da Secretaria do Tribunal, em livro próprio, o termo de posse do Procurador-Geral e dos procuradores.

Art. 60. Em caso de vacância e em suas ausências e impedimentos por motivo de licença, férias ou outro afastamento legal, o Procurador-Geral será substituído pelos subprocuradores-gerais e, na ausência destes, pelos procuradores, observada, em ambos os casos, a ordem de antiguidade da posse, da nomeação e de classificação no concurso público de ingresso na carreira, sucessivamente.

Parágrafo único. Nessas substituições, os subprocuradores-gerais e procuradores farão jus ao subsídio do cargo substituído.

Art. 61. Aos membros do Ministério Público junto ao Tribunal aplica-se o disposto no art. 37 e no inciso VIII e $\S 1^{\circ}$ do art. 39 deste Regimento, no art. 130 da Constituição Federal e, subsidiariamente, no que couber, na Lei Complementar $n^{\circ} 75$, de 20 de maio de 1993.

Art. 62. Compete ao Procurador-Geral e, por delegação prevista no art. 82 da Lei no 8.443, de 1992, aos subprocuradores-gerais e procuradores:

I - promover a defesa da ordem jurídica, requerendo, perante o Tribunal, as medidas de interesse da Justiça, da Administração e do erário;

II - comparecer às sessões do Tribunal;

III - dizer de direito, oralmente ou por escrito, em todos os assuntos sujeitos à decisão do Tribunal, sendo obrigatória sua audiência nos processos de tomada ou prestação de contas e nos concernentes aos atos de admissão de pessoal e de concessão de aposentadorias, reformas e pensões;

IV - interpor os recursos permitidos em lei ou previstos neste Regimento;

V - promover junto à Advocacia-Geral da União ou, conforme o caso, perante os dirigentes das entidades jurisdicionadas do Tribunal, as medidas previstas no inciso II do art. 219 e no art. 275, remetendo-lhes a documentação e instruções necessárias;

VI - requerer as providências previstas nos arts. 40 e 44 da Lei no 8.443, de 1992;

VII - requisitar ao Presidente o apoio administrativo e de pessoal da Secretaria do Tribunal necessários ao desempenho da missão do Ministério Público, nos termos do art. 83 da Lei n $^{\circ}$ 8.443 , de

1992;

VIII - elaborar relatório anual contendo o andamento dos processos de execução dos acórdãos do Tribunal e a resenha das atividades específicas a cargo do Ministério Público, relativas ao exercício encerrado.

$\S 1^{\circ}$ Compete, ainda, ao Procurador-Geral avocar, quando julgar necessário, processo que esteja sob exame de qualquer dos membros do Ministério Público.

$\S 2^{\circ} \mathrm{Na}$ oportunidade em que emitir seu parecer, o Ministério Público, mesmo que suscite questão preliminar, manifestar-se-á também quanto ao mérito, ante a eventualidade daquela não ser acolhida.

Art. 63. Os membros do Ministério Público terão direito a sessenta dias de férias por ano, de acordo com escala aprovada pelo Procurador-Geral no mês de dezembro. 
$\S 1^{\circ} \mathrm{Na}$ escala referida no caput não devem coincidir as férias de mais de três membros do Ministério Público, os quais poderão, a qualquer tempo, interrompê-las por necessidade do serviço, facultando-se ao interessado gozar o restante do período em época oportuna.

$\S 2^{\circ}$ O Procurador-Geral remeterá à Presidência do Tribunal, no mês de dezembro de cada ano, cópia da escala de férias anual e, quando ocorrerem, as suas alterações, para as devidas anotações nos respectivos assentamentos individuais.

Art. 64. O Procurador-Geral baixará as instruções que julgar necessárias, definindo as atribuições dos subprocuradores-gerais e procuradores, disciplinando os critérios de promoção dos procuradores e os serviços internos do Ministério Público junto ao Tribunal.

\section{CAPÍTULO XIII SECRETARIA}

Art. 65. À Secretaria do Tribunal incumbe a prestação de apoio técnico e a execução dos serviços administrativos do Tribunal de Contas da União.

$\S 1^{\circ}$ A estrutura, competência e funcionamento das unidades da Secretaria do Tribunal serão fixados em ato normativo.

$\S 2^{\circ} \mathrm{O}$ Presidente do Tribunal baixará normas dispondo sobre o funcionamento das unidades da Secretaria durante o período de recesso a que se refere o parágrafo único do art. 92.

Art. 66. Para cumprir as suas finalidades, a Secretaria do Tribunal disporá de quadro próprio de pessoal, organizado em plano de carreiras, cujos princípios, diretrizes, denominações, estruturação, formas de provimento e demais atribuições são os fixados em lei específica.

\section{TÍTULO III \\ DELIBERAÇÕES E JURISPRUDÊNCIA \\ CAPÍTULO I \\ DELIBERAÇÕES DO PLENÁRIO E DAS CÂMARAS}

Art. 67. As deliberações do Plenário e, no que couber, das câmaras, terão a forma de:

I - instrução normativa, quando se tratar de disciplinamento de matéria que envolva pessoa física, órgão ou entidade sujeita à jurisdição do Tribunal;

II - resolução, quando se tratar de:

a) aprovação do Regimento Interno, de ato definidor da estrutura, atribuições e funcionamento do Tribunal, das unidades de sua Secretaria e demais serviços auxiliares;

b) outras matérias de natureza administrativa interna que, a critério do Tribunal, devam revestirse dessa forma;

III - decisão normativa, quando se tratar de fixação de critério ou orientação, e não se justificar a expedição de instrução normativa ou resolução;

IV - parecer, quando se tratar de:

a) Contas do Presidente da República;

b) outros casos em que, por lei, deva o Tribunal assim se manifestar;

V - acórdão, quando se tratar de deliberação em matéria da competência do Tribunal de Contas da União, não enquadrada nos incisos anteriores.

Parágrafo único. As deliberações previstas neste artigo serão formalizadas nos termos estabelecidos em ato normativo.

Art. 68. Os acórdãos serão redigidos pelo relator ou pelo redator, na forma do art. 126, e assinados eletronicamente por um deles, conforme o caso, pelo Presidente do respectivo 
colegiado e pelo representante do Ministério Público, na forma estabelecida em norma específica.

$\S 1^{\circ} \mathrm{O}$ acórdão correspondente ao voto de desempate proferido pelo Presidente será por este assinado e pelo representante do Ministério Público.

$\S 2^{\circ}$ As assinaturas do Presidente e do representante do Ministério Público suprirão a ausência da assinatura do relator ou do redator, se estes não comparecerem à sessão na qual se conclua a votação.

Art. 69. São partes essenciais das deliberações do Tribunal:

I - o relatório do relator, de que constarão, quando houver, o teor integral da parte dispositiva da deliberação recorrida quando se tratar de recurso, as conclusões da equipe de fiscalização, ou do servidor responsável pela análise do processo, bem como as conclusões dos pareceres das chefias da unidade técnica e do Ministério Público junto ao Tribunal, afora para os processos constantes de Relação, segundo as hipóteses do art. 143;

II - a fundamentação com que o relator analisar as questões de fato e de direito, dispensada a elaboração de considerandos, exceto nos casos do $\S 3^{\circ}$ do art. 143;

III - o dispositivo com que o relator decidir sobre o mérito do processo;

IV - as ressalvas, quando feitas pelos votantes.

Art. 70. As instruções normativas, resoluções e decisões normativas serão assinadas eletronicamente pelo Presidente, com a redação final aprovada pelo Plenário.

Art. 71. Os pareceres serão redigidos pelo relator e assinados:

I - por todos os ministros e ministros-substitutos convocados, quando se tratar das Contas do

Presidente da República;

II - pelo Presidente e pelo relator, nos demais casos.

\section{CAPÍTULO II \\ ELABORAÇÃO, APROVAÇÃO E ALTERAÇÃO DE ATOS NORMATIVOS}

Art. 72. O Regimento Interno do Tribunal somente poderá ser alterado mediante aprovação, pela maioria absoluta de seus ministros, de projeto de resolução.

Art. 73. A apresentação de projeto concernente a enunciado da súmula, instrução normativa, resolução ou decisão normativa é de iniciativa do Presidente, dos ministros e das comissões de Regimento

e de Jurisprudência, podendo ser ainda sugerida por ministro-substituto ou representante do Ministério Público.

Art. 74. O projeto, com a respectiva justificação, será apresentado em Plenário, competindo ao Presidente proceder ao sorteio do relator.

Parágrafo único. Quando a matéria for de competência das comissões de Regimento ou de Jurisprudência, o sorteio do relator será efetuado somente após a manifestação da respectiva comissão.

Art. 75. O projeto concernente a instrução normativa, resolução e decisão normativa poderá receber emendas dos ministros ou sugestões dos ministros-substitutos e do Procurador-Geral junto a este Tribunal, dentro do prazo proposto pelo relator, com a anuência do Plenário.

$\S 1^{\circ} \mathrm{O}$ relator submeterá ao Plenário, na sessão ordinária seguinte àquela em que houver sido designado, a proposta do prazo referido no caput, cujo termo inicial será o dia seguinte à data da sessão.

$\S 2^{\circ}$ Caso o relator apresente substitutivo, depois de apreciadas as alterações propostas ao projeto original, será reaberto outro prazo, sugerido por ele ao Plenário, para o oferecimento de novas emendas ou sugestões. 
$\S 3^{\circ}$ Entende-se como substitutivo o projeto elaborado pelo relator, que altera, substancialmente, o projeto original.

Art. 76. Nos projetos de atos normativos em que haja manifestação da Comissão de Regimento ou da Comissão de Jurisprudência, será distribuído aos ministros, ministros-substitutos e ao Procurador-Geral, para fins de apresentação de emendas ou de sugestões, conforme o caso, a versão que

houver sido por elas aprovada, acompanhada das respectivas justificações.

Parágrafo único. O ministro que houver sido designado para relatar projeto de ato normativo no âmbito das comissões será excluído do sorteio a que se refere o art. 74 .

Art. 77. As emendas e sugestões serão encaminhadas diretamente ao relator da matéria.

Art. 78. A emenda, de acordo com a sua natureza, será assim classificada:

I - supressiva, quando objetivar excluir artigo, parágrafo, inciso ou alínea do projeto;

II - aditiva, quando pretender acrescentar artigo, parágrafo, inciso ou alínea ao projeto;

III - modificativa, quando alterar dispositivo do projeto;

IV - substitutiva, quando apresentada como sucedânea do projeto, alterando-o substancialmente.

Art. 79. Encerrado o prazo para emendas e sugestões, o relator apresentará, até a segunda sessão plenária seguinte, o relatório e o parecer sobre o projeto original ou o substitutivo e as alterações propostas.

Art. 80. Encerrada a discussão, a matéria entrará em votação, observada a seguinte ordem:

I - substitutivo do relator;

II - substitutivo de ministro;

III - projeto originário;

IV - subemendas do relator;

$\mathrm{V}$ - emendas com parecer favorável;

VI - emendas com parecer contrário.

$\S 1^{\circ} \mathrm{A}$ aprovação de substitutivo prejudica a votação das demais proposições, salvo os destaques requeridos.

$\S 2^{\circ}$ Os requerimentos de destaque destinam-se a permitir votação em separado da correspondente matéria, podendo incidir sobre emendas, subemendas e partes do projeto ou do substitutivo.

Art. 81. Considerar-se-á aprovada a proposição que obtiver maioria absoluta de votos dos ministros.

Art. 82. A redação final será votada na mesma sessão ou na sessão plenária seguinte àquela em que for aprovado o projeto concernente a enunciado de súmula, instrução normativa, resolução ou decisão normativa.

Parágrafo único. Será dispensada a votação da redação final se aprovado o projeto originário, sem emendas, ou o substitutivo integralmente.

Art. 83. Somente será admitida emenda à redação final para evitar incorreções gramaticais ou para maior clareza e objetividade do texto.

Art. 84. Os prazos previstos nos $\S \S 1^{\circ}$ e $2^{\circ}$ do art. 75 poderão ser dispensados, reduzidos ou ampliados, a critério do Plenário, mediante proposta justificada do Presidente ou do relator.

Parágrafo único. O prazo de apresentação do relatório e parecer previsto no art. 79 poderá ser ampliado, a critério do Plenário, mediante proposta justificada do relator.

\author{
CAPÍTULO III \\ JURISPRUDÊNCIA
}


Art. 85. A Súmula da Jurisprudência constituir-se-á de princípios ou enunciados, resumindo teses, soluções, precedentes e entendimentos, adotados reiteradamente pelo Tribunal, ao deliberar sobre assuntos ou matérias de sua jurisdição e competência.

Art. 86. Na organização gradativa da Súmula, a cargo da unidade responsável pelo secretariado das sessões do Tribunal, será adotada numeração de referência para os enunciados, aos quais se seguirá a menção dos dispositivos legais e dos julgados em que se fundamentam.

Art. 87. Poderá ser incluído, revisto, revogado ou restabelecido, na Súmula, qualquer enunciado, mediante aprovação pela maioria absoluta dos ministros do projeto específico a que se refere o art. 73 .

Art. 88. Ficarão vagos, com nota de cancelamento, os números dos enunciados que o Tribunal revogar, conservando os mesmos números os que forem apenas modificados, fazendo-se a ressalva correspondente.

Art. 89. A Súmula e suas alterações serão publicadas nos órgãos oficiais.

Art. 90. A citação da Súmula será feita pelo número correspondente ao seu enunciado e dispensará, perante o Tribunal, a indicação de julgados no mesmo sentido.

\section{CAPÍTULO IV \\ INCIDENTE DE UNIFORMIZAÇÃO DE JURISPRUDÊNCIA}

Art. 91. Ao apreciar processo em que seja suscitada divergência entre deliberações anteriores do Tribunal, poderá o colegiado, por sugestão de ministro, ministro-substituto ou representante do Ministério Público, decidir pela apreciação preliminar da controvérsia, em anexo aos autos principais, retirando a matéria de pauta.

$\S 1^{\circ}$ Se reconhecer a existência da divergência, o relator solicitará a audiência do Ministério Público, submetendo em seguida a questão à deliberação do Plenário até a segunda sessão subsequente.

$\S 2^{\circ}$ Dirimida a divergência jurisprudencial, a apreciação do processo quanto ao mérito terá prosseguimento na mesma sessão do Plenário, ressalvados os casos do inciso VII do art. 17.

$\S 3^{\circ} \mathrm{O}$ acórdão que resolver a divergência será remetido à Comissão de Jurisprudência para oportuna apreciação da necessidade de elaboração de enunciado de Súmula sobre a matéria.

$\S 4^{\circ}$ Não sendo reconhecida pelo relator a existência de divergência, levará seus fundamentos ao Plenário que, ao acolhê-los, prosseguirá na apreciação do mérito do processo, se matéria de sua competência, ou encaminhá-lo-á à câmara originária.

$\S 5^{\circ}$ Se o Plenário, dissentindo do relator, entender pela existência de divergência, prosseguirá na forma dos $\S \S 1^{\circ}, 2^{\circ}$ e $3^{\circ}$, passando a funcionar como revisor para o incidente o ministro que primeiro proferir o voto dissidente.

\section{TÍTULO IV \\ SESSÕES \\ CAPÍTULO I \\ SESSÕES DO PLENÁRIO}

Art. 92. O Tribunal se reúne, anualmente, no Distrito Federal, no período de 17 de janeiro a 16 de dezembro.

Parágrafo único. O recesso previsto no art. 68 da Lei ${ }^{\circ} 8.443$, de 1992, compreendido no período de 17 de dezembro a 16 de janeiro, não ocasionará a paralisação dos trabalhos do Tribunal, nem a suspensão ou interrupção dos prazos processuais. 
Art. 93. As sessões do Plenário serão ordinárias e extraordinárias e, ressalvadas as hipóteses previstas nos incisos III e VII do art. 96 e observado o disposto no $\S 3^{\circ}$ do art. 24 e no $\S 1^{\circ}$ do art. 36, somente poderão ser abertas com o quórum de cinco ministros ou ministros-substitutos convocados, exclusive o Presidente.

$\S 1^{\circ}$ Caso o quórum indicado no caput venha a ser comprometido em virtude de declarações de impedimento de um ou mais ministros ou ministros-substitutos convocados, o Presidente poderá retirar o processo de pauta e convocar, para uma próxima sessão, ministros-substitutos em número suficiente à recomposição do quórum, quando se dará início a nova discussão e votação acerca da matéria, a menos que seja possível a aplicação do disposto na alínea b do inciso II do art. 55.

$\S 2^{\circ}$ Nenhuma sessão poderá ser realizada sem a presença do representante do Ministério Público junto ao Tribunal, exceto nas hipóteses a que se referem os incisos III e VII do art. 96. Art. 94. As sessões ordinárias serão realizadas às quartas-feiras, com início às 14 horas e 30 minutos e término às 18 horas e 30 minutos, podendo haver intervalo de até trinta minutos.

$\S 1^{\circ}$ Por proposta do Presidente, de ministro, de ministro-substituto ou do representante do Ministério Público, aprovada pelo Plenário, a sessão ordinária poderá ser interrompida para realização de sessão extraordinária, de caráter reservado, prevista no art. 97.

$\S 2^{\circ}$ A critério do Plenário, por proposta do Presidente, as sessões ordinárias poderão ser prorrogadas por até sessenta minutos.

$\S 3^{\circ}$ Salvo nas hipóteses previstas nos arts. 112 e 119 e no $\S 1^{\circ}$ do art. 124 , o julgamento de contas ou a apreciação de processo de fiscalização a cargo do Tribunal, uma vez iniciado, ultimar-se-á na mesma sessão, ainda que excedida a hora regimental.

$\S 4^{\circ}$ Caso ocorra convocação de sessão extraordinária para os fins previstos nos incisos I a IV do art. 96, não será realizada sessão ordinária, se houver coincidência de data e horário.

$\S 5^{\circ}$ Se o horário da sessão convocada nos termos do art. 98 coincidir, em parte, com o da sessão ordinária, esta poderá ter início logo após o encerramento da sessão extraordinária.

$\S 6^{\circ}$ A última sessão ordinária do Tribunal realizar-se-á na primeira quarta-feira do mês de dezembro.

$\S 7^{\circ} \mathrm{O}$ julgamento de mérito de determinadas matérias ou tipos de processo poderá também ser realizado por meio eletrônico, nos termos e condições definidos em resolução.

Art. 95. Nas sessões ordinárias, será observada, preferencialmente, a seguinte ordem de trabalho:

I - homologação da ata da sessão anterior;

II - sorteio dos relatores de processos, conforme previsto no art. 102;

III - expediente, nos termos do art. 103;

IV - apreciação das medidas cautelares adotadas pelos relatores ou pelo Presidente, nos termos do $\S 1^{\circ}$ do art. 276 ;

V - julgamento ou apreciação dos processos constantes de Relação, nas hipóteses do art. 143;

VI - julgamento ou apreciação dos demais processos incluídos em pauta, observado o disposto no art. 141.

Art. 96. As sessões extraordinárias serão convocadas para os seguintes fins:

I - posse do Presidente e do Vice-Presidente;

II - apreciação das Contas do Presidente da República;

III - posse de ministro, de ministro-substituto e do Procurador-Geral;

IV - eleição do Presidente ou do Vice-Presidente, na hipótese prevista no $\S 4^{\circ}$ do art. 24;

V - deliberação acerca da lista tríplice dos ministros-substitutos e dos membros do Ministério

Público junto ao Tribunal, para preenchimento de cargo de ministro, na forma prevista no art. 
VI - julgamento ou apreciação dos processos restantes da pauta de sessão ordinária ou extraordinária, ou que, pela sua urgência, sejam incluídos em pauta extraordinária, observado o disposto no art. 141;

VII - outros eventos, a critério do Plenário.

Art. 97. O Plenário poderá realizar sessões extraordinárias de caráter reservado quando a preservação de direitos individuais e o interesse público o exigirem, bem como para julgar ou apreciar os processos que derem entrada ou se formarem no Tribunal com chancela de sigiloso. Parágrafo único. As sessões extraordinárias a que se refere o caput serão realizadas exclusivamente com a presença dos ministros, ministros-substitutos, representante do Ministério Público, das partes e de seus procuradores, quando a requererem, e de servidores do gabinete das autoridades e da unidade responsável pelo secretariado das sessões, autorizados pelo Presidente.

$\S 2^{\circ}$ (Revogado).

Art. 98. As sessões extraordinárias, ressalvado o disposto no $\S 1^{\circ}$ do art. 94 , serão convocadas com antecedência mínima de vinte e quatro horas pelo Presidente, de ofício, ou por proposta de ministro ou ministro-substituto, observado, por ocasião da necessidade de inclusão de processo em pauta, o disposto no art. 141.

Art. 99. À hora prevista, o Presidente declarará aberta a sessão, mencionando os nomes dos ministros, dos ministros-substitutos e do representante do Ministério Público junto ao Tribunal presentes e indicando os nomes dos ausentes e os motivos das respectivas ausências, quando cientificado.

Art. 100. Se não houver quórum, a matéria constante da ordem dos trabalhos ficará automaticamente transferida para a sessão seguinte.

Art. 101. Havendo quórum, passar-se-á, se for o caso, à homologação da ata da sessão anterior, previamente disponibilizada, preferencialmente em meio eletrônico, aos gabinetes dos ministros, dos ministros-substitutos e do representante do Ministério Público.

Parágrafo único. A ata de cada sessão deverá ser submetida a homologação até a segunda sessão ordinária seguinte.

Art. 102. Homologada a ata, passar-se-á, se for o caso, aos sorteios previstos nos arts. 150, 154 e 155.

Art. 103. Proceder-se-á, em seguida, ao expediente, para comunicações, indicações, moções e requerimentos, os quais, quando couber, serão objeto de deliberação do Plenário e incluídos em ata.

Art. 104. Encerrada a fase do expediente, seguir-se-á a apreciação das medidas cautelares adotadas pelo Presidente ou pelos relatores, nos termos do $\S 1^{\circ}$ do art. 276.

Art. 105. Após a apreciação das medidas cautelares a que se refere o artigo anterior, e de acordo com a competência estabelecida nos arts. 15 e 16, serão apreciados ou julgados os processos constantes das Relações previstas no art. 143, e depois os demais processos incluídos na pauta, organizados por relator, os quais relatarão sequencialmente todos os seus processos, identificados por classes de assuntos, conforme a natureza, observada a seguinte ordem preferencial:

I - recursos;

II - pedidos de informação e outras solicitações formuladas pelo Congresso Nacional, por qualquer de suas casas ou respectivas comissões;

III - consultas;

IV - tomadas e prestações de contas;

$\mathrm{V}$ - auditorias e inspeções; 
VI - matérias remetidas pelo relator ou pelas câmaras, na forma estabelecida no $§ 1^{\circ}$ do art. 17 e no art. 139;

VII - denúncias, representações e outros assuntos de competência do Plenário.

$\S 1^{\circ}$ No julgamento e apreciação dos processos será respeitada a ordem de antiguidade decrescente dos relatores, salvo pedido de preferência deferido pelo Plenário, de ministro ou ministro-substituto, formulado, oralmente, no início da sessão.

$\S 2^{\circ}$ Terá preferência para julgamento ou apreciação o processo incluído em pauta no qual deva ser produzida sustentação oral.

Art. 106. É facultado ao relator limitar-se a enunciar a identificação do processo e a ler a minuta de acórdão, ressalvado quando houver sustentação oral, caso em que se observará o art. 168.

$\S 1^{\circ}$ A simples leitura da minuta de acórdão não dá início à fase de votação, podendo, ainda, a matéria ser discutida.

$\S 2^{\circ}$ Cabe ao relator prestar os esclarecimentos solicitados no curso dos debates.

Art. 107. O Presidente, durante a discussão, poderá aduzir informações que orientem o Plenário.

Art. 108. No curso da discussão, o relator, qualquer ministro ou ministro-substituto poderá solicitar a audiência do Ministério Público junto ao Tribunal.

Art. 109. O representante do Ministério Público poderá, ainda, usar da palavra, a seu pedido, para prestar esclarecimentos, alegar ou requerer o que julgar oportuno.

Art. 110. Nenhum ministro ou ministro-substituto falará sem que o Presidente lhe conceda a palavra, nem interromperá, sem licença, o que dela estiver usando.

Art. 111. O Ministro ou Ministro-Substituto que alegar impedimento ou suspeição, de acordo com o parágrafo único do art. 151, não participará da discussão e da votação do processo.

Art. 112. Na fase de discussão, qualquer ministro ou ministro-substituto convocado poderá pedir vista do processo, passando a funcionar como revisor, sendo facultado ao representante do Ministério Público fazer o mesmo pedido.

$\S 1^{\circ} \mathrm{O}$ processo será encaminhado pela unidade responsável pelo secretariado das sessões, no mesmo dia, a quem houver requerido vista, sendo devolvido ao relator, preferencialmente, até a segunda sessão seguinte, para inclusão na pauta da sessão subsequente, obedecido o disposto no art. 141.

$\S 2^{\circ}$ A vista requerida ou sugerida ao Ministério Público poderá se dar em mesa, durante a sessão, ficando a discussão da matéria suspensa até seu pronunciamento.

$\S 3^{\circ}$ Novos pedidos de vista poderão ser concedidos, pelo prazo fixado no $\S 1^{\circ}$, para cada solicitante, devendo o processo ser restituído pelo último deles ao relator, de preferência para inclusão na pauta da próxima sessão, obedecido o disposto no art. 141.

$\S 4^{\circ}$ Se o revisor, por qualquer motivo, não puder comparecer à sessão, será considerado como desistente do pedido de vista, salvo prévia justificação dirigida ao Presidente do colegiado.

$\S 5^{\circ}$ Voltando o processo à pauta, será reaberta a discussão, dando-se a palavra ao relator, que apresentará novamente a matéria, podendo falar, em seguida, conforme o caso, os revisores e o representante do Ministério Público, na ordem em que foram formulados os respectivos pedidos de vista.

$\S 6^{\circ}$ Ainda na fase de discussão, qualquer ministro ou ministro-substituto convocado poderá antecipar seu voto, quando houver pedido de vista.

$\S 7^{\circ} \mathrm{Na}$ hipótese do parágrafo anterior, fica assegurado ao representante do Ministério Público o direito de pedir vista do processo.

Art. 113. A discussão também poderá ser adiada, por decisão do Plenário, mediante proposta fundamentada do Presidente, de qualquer ministro ou de ministro-substituto convocado, nos seguintes casos:

I - se a matéria requerer maior estudo; 
II - para instrução complementar, por considerar-se incompleta;

III - se for solicitada a audiência do Ministério Público;

IV - se for requerida sua apreciação em sessão posterior.

Parágrafo único. As providências previstas nos incisos I a III deverão ser processadas em caráter de urgência.

Art. 114. Apresentado o processo pelo relator e não mais havendo quem queira discutir a matéria, o Presidente encerrará a fase de discussão e abrirá, a seguir, a fase de votação.

Art. 115. Se a matéria versar sobre questões diferentes, embora conexas, o Presidente poderá submetê-las a discussão e votação em separado.

Art. 116. As questões preliminares ou prejudiciais serão decididas antes do julgamento ou da apreciação de mérito proposta pelo relator.

$\S 1^{\circ} \mathrm{Se}$ a preliminar versar sobre falta ou impropriedade sanável, o Tribunal poderá converter o julgamento ou apreciação em diligência.

$\S 2^{\circ}$ Rejeitada a preliminar, dar-se-á a palavra ao relator e, se for o caso, aos revisores, para apresentarem os seus votos, com as correspondentes minutas de acórdão.

Art. 117. Apresentados os votos a que se refere o $\S 2^{\circ}$ do artigo anterior, qualquer ministro ou ministro-substituto convocado poderá se manifestar sobre a matéria em discussão.

Art. 118. Concluída a fase de encaminhamento, o Presidente tomará os demais votos, primeiramente dos ministros-substitutos convocados e depois dos ministros, observada a ordem crescente de antiguidade em ambos os casos, exceto na sessão que aprecia as Contas do Presidente da República, quando a ordem de tomada de declarações de votos será invertida.

$\S 1^{\circ}$ Antes de proclamado o resultado da votação, cada ministro ou ministro-substituto convocado, caso modifique o seu voto, poderá falar uma vez, sendo facultado ao Presidente de ofício ou a pedido, reabrir a discussão.

$\S 2^{\circ}$ Nenhum ministro ou ministro-substituto convocado presente à sessão poderá deixar de votar, salvo se declarar impedimento ou suspeição, nos termos do art. 111, e na hipótese prevista no art. 123.

$\S 3^{\circ}$ Não poderá, ainda, participar da votação o ministro ou ministro-substituto convocado para substituí-lo quando um deles já houver proferido o seu voto.

Art. 119. Na fase de votação, o julgamento ou apreciação serão suspensos quando houver pedido de vista solicitado por ministro ou ministro-substituto convocado, que passará a funcionar como revisor, sem prejuízo de que os demais ministros e ministros-substitutos convocados profiram seus votos na mesma sessão, desde que se declarem habilitados.

$\S 1^{\circ} \mathrm{O}$ processo será encaminhado pela unidade responsável pelo secretariado das sessões do Tribunal, no mesmo dia, ao revisor, que deverá incluí-lo em pauta para prosseguimento da votação, preferencialmente até a quarta sessão subsequente, obedecido o disposto no art. 141, desde que esteja presente o relator, salvo se com este concordar o revisor.

$\S 2^{\circ}$ Caso o pedido de vista, com base neste artigo ou no art. 112, haja sido feito por ministrosubstituto convocado, caberá a este votar no lugar do ministro substituído, mesmo que cessada a convocação.

$\S 3^{\circ}$ Ao dar prosseguimento à votação, serão computados os votos já proferidos pelos ministros ou ministros-substitutos convocados, ainda que não compareçam ou hajam deixado o exercício do cargo, cabendo ao Presidente esclarecer a matéria e apresentar o resumo da votação até então procedida.

$\S 4^{\circ} \mathrm{O}$ relator, os ministros ou os ministros-substitutos convocados que já tenham proferido seus votos poderão modificá-los até a conclusão do julgamento ou apreciação do processo.

Art. 120. A votação também será suspensa quando for sugerida alteração na minuta de acórdão, acolhida pelo relator, até a leitura de sua redação final. 
Art. 121. O ministro que estiver momentaneamente substituindo o Presidente na sessão poderá pedir vista de processo.

Art. 122. Na hipótese de pedido de vista, na forma do art. 112, se o relator tiver deixado o Tribunal, o revisor submeterá o processo à deliberação do colegiado.

Parágrafo único. Se o pedido de vista se deu com fundamento no art. 119, será computado o voto do relator, mesmo que já tenha deixado o Tribunal, não votando quem lhe tenha sucedido. Art. 123. Não participará da votação o ministro ou ministro-substituto convocado que esteve ausente por ocasião da apresentação e discussão do relatório, salvo se der por esclarecido.

Art. 124. Caberá ao Presidente do Tribunal ou ao ministro que estiver na Presidência do Plenário proferir voto de desempate.

$\S 1^{\circ}$ Caso não se julgue habilitado a proferir o voto de desempate, deverá fazê-lo, preferencialmente, na primeira sessão a que comparecer.

$\S 2^{\circ}$ Se o Presidente do Tribunal declarar impedimento ou suspeição no momento do desempate, a votação será reiniciada com a convocação de um ministro-substituto presente à sessão, apenas para esse fim, observada a ordem de antiguidade no cargo.

$\S 3^{\circ}$ Não sendo possível convocar um ministro-substituto para a mesma sessão, o processo será reincluído em pauta para julgamento ou apreciação em nova data, reiniciando-se a votação.

$\S 4^{\circ}$ Nas hipóteses dos $\S \S 2^{\circ}$ e $3^{\circ}$, poderá o Presidente do Tribunal continuar presidindo a sessão, durante a reapreciação ou julgamento do processo.

$\S 5^{\circ}$ A mesma solução dos $\S \S 2^{\circ}$ e $3^{\circ}$ será dada quando o empate decorrer do voto do Presidente. Art. 125. Encerrada a votação, o Presidente proclamará o resultado, declarando-o:

I - por unanimidade;

II - por maioria simples;

III - por 2/3 dos ministros, inclusive ministros-substitutos convocados;

IV - por maioria absoluta;

V - por voto de desempate.

Parágrafo único. O disposto no inciso IV do caput aplica-se aos casos previstos no art. 49, no $\S$ $6^{\circ}$ do art. 50 e nos arts. 72, 81, 87 e 270 deste Regimento Interno.

Art. 126. Vencido no todo o voto do relator, o ministro ou ministro-substituto convocado que houver proferido em primeiro lugar o voto vencedor atuará como redator, cabendo-lhe redigir e assinar o acórdão e a respectiva declaração de voto.

Parágrafo único. Vencido em parte o voto do relator, o acórdão será também por este assinado. Art. 127. Quando forem apresentadas mais de duas propostas de mérito, dar-se-á a apuração mediante votações sucessivas, das quais participarão todos os ministros e ministros substitutos convocados que participaram da fase de discussão, observando-se o seguinte procedimento: I - será, desde logo, declarada vencedora a proposta de mérito que superar, em número de votos, a soma dos votos das demais propostas;

II - não ocorrendo a hipótese prevista no inciso anterior, elimina-se a proposta menos votada entre elas e submetem-se à votação as propostas que obtiverem os maiores números de votos.

Parágrafo único. Havendo duas ou mais propostas com o mesmo número de votos, serão colocadas inicialmente em votação as duas propostas que mais se assemelhem, observando-se, a seguir, o disposto no inciso II.

Art. 128. Qualquer ministro ou ministro-substituto convocado poderá apresentar por escrito, no prazo de quarenta e oito horas, a sua declaração de voto, que será anexada ao processo, desde que faça comunicação nesse sentido, logo após a proclamação do resultado.

Parágrafo único. Será obrigatória a apresentação de declaração de voto quando o ministro ou ministro-substituto convocado proferir voto divergente ou votar com ressalva. 
Art. 129. Qualquer ministro ou ministro-substituto convocado poderá pedir reexame de processo julgado na mesma sessão e com o mesmo quórum.

Art. 130. Se o adiantado da hora não permitir que todos os processos constantes da pauta sejam julgados ou apreciados, o Presidente, antes de encerrar a sessão, determinará, de ofício ou mediante proposta de qualquer ministro ou ministro-substituto convocado, que os processos restantes, cujos relatores estejam presentes, tenham preferência na sessão seguinte.

Parágrafo único. Os processos transferidos para a sessão seguinte, que, por qualquer motivo, nela deixarem de ser relatados, serão automaticamente excluídos de pauta e somente serão apreciados ou julgados quando reincluídos por expressa iniciativa do relator, obedecido o disposto no art. 141.

Art. 131. Por proposta de ministro, ministro-substituto ou de representante do Ministério Público, o Tribunal poderá:

I - determinar a supressão, nas peças processuais, de palavras ou expressões desrespeitosas ou descorteses, incompatíveis com o tratamento devido ao Tribunal e às autoridades públicas em geral;

II - mandar retirar dos autos as peças consideradas, em seu conjunto, nas condições definidas no inciso anterior.

Art. 132. Esgotada a ordem de trabalho, o Presidente declarará encerrada a sessão.

Art. 133. As atas das sessões serão lavradas pela unidade responsável por seu secretariado e delas ou de seus anexos deverão constar:

I - o dia, mês e ano, bem como a hora da abertura e do encerramento da sessão;

II - o nome do ministro que presidiu a sessão e do secretário desta;

III - os nomes dos ministros, dos ministros-substitutos e do representante do Ministério Público presentes;

IV - os nomes dos ministros e dos ministros-substitutos que não compareceram e o motivo da ausência, quando cientificado;

$\mathrm{V}$ - os sorteios, o expediente e as comunicações a que se referem os arts. 102, 103 e 104;

VI - os acórdãos proferidos, acompanhados dos correspondentes relatórios, votos, declarações de votos e votos revisores, desde que concluído o julgamento, bem como os relatórios, votos, declarações de votos e votos revisores já exarados nos processos cuja apreciação foi adiada; VII - as demais ocorrências, indicando-se, quanto aos processos:

a) as declarações de voto apresentadas e os pareceres considerados necessários ao perfeito conhecimento da matéria;

b) os pedidos de vista.

Parágrafo único. Quando o Tribunal deliberar, em sessão extraordinária de caráter reservado, pelo levantamento do sigilo de processo, a deliberação e, se for o caso, o relatório e voto em que se fundamentar constarão da respectiva ata a ser publicada, a qual identificará ainda os outros processos examinados, bem como o número dos acórdãos neles proferidos, mantendose, conforme a preservação dos direitos individuais e o interesse público o exigirem, o sigilo das demais informações.

\section{CAPÍTULO II SESSÕES DAS CÂMARAS}

Art. 134. As sessões das câmaras serão ordinárias e extraordinárias, e somente poderão ser abertas com o quórum de três ministros ou ministros-substitutos convocados, incluindo o Presidente. 
$\S 1^{\circ}$ Caso o quórum indicado no caput venha a ser comprometido em virtude de declarações de impedimento ou de suspeição de um ou mais ministros ou ministros-substitutos convocados, o Presidente da câmara respectiva poderá retirar o processo de pauta e solicitar à Presidência do Tribunal a convocação, para uma próxima sessão, de ministros-substitutos em número suficiente à recomposição do quórum, quando se dará início a nova discussão e votação acerca da matéria, a menos que seja possível a aplicação do disposto na alínea b do inciso II do art. 55 . $\S 2^{\circ}$ A convocação dos ministros-substitutos a que se refere o parágrafo anterior será feita, preferencialmente, entre aqueles que já atuam na respectiva câmara e, em situações excepcionais, poderá ser utilizada a prerrogativa prevista no $\S 3^{\circ}$ do art. 55.

$\S 3^{\circ} \mathrm{Na}$ impossibilidade de convocação de ministros-substitutos, os ministros poderão atuar em outra câmara de que não sejam membros efetivos, mediante designação do Presidente do Tribunal, por solicitação de presidente de câmara.

$\S 4^{\circ}$ A nova votação de que trata o $\S 1^{\circ}$ dar-se-á ao início da sessão para a qual houve a convocação.

$\S 5^{\circ}$ As câmaras poderão realizar sessões extraordinárias de caráter reservado para julgamento ou apreciação de processos de sua competência que derem entrada ou se formarem no Tribunal com chancela de sigiloso.

$\S 6^{\circ}$ As sessões extraordinárias a que se refere o parágrafo anterior serão realizadas exclusivamente com a presença dos ministros, dos ministros-substitutos, do representante do Ministério Público, das partes e de seus procuradores, quando a requererem, e de servidores do gabinete das autoridades e da unidade responsável pelo secretariado das sessões, autorizados pelo Presidente.

Art. 135. As sessões ordinárias da Primeira e da Segunda câmaras realizar-se-ão às terças-feiras, com início às 15 horas e às 16 horas, respectivamente.

Art. 136. Ocorrendo convocação de sessão extraordinária do Plenário, a sessão ordinária da câmara, se houver coincidência de data e de horário, poderá ser realizada, posteriormente, em data e horário estabelecidos pelo seu Presidente.

Art. 137. O julgamento ou apreciação pelas câmaras começará com os processos constantes de Relação, seguindo-se os processos que contenham pedido de sustentação oral e, depois, os demais processos incluídos em pauta, de acordo com a competência estabelecida no art. 17, divididos por classes de assuntos, conforme sua natureza, com observância da antiguidade dos ministros e ministros-substitutos, os quais relatarão todos os seus processos em conjunto, com a observância da seguinte ordem preferencial:

I - recursos;

II - tomadas e prestações de contas;

III - auditorias, inspeções e outras matérias concernentes a fiscalização;

IV - atos de admissão de pessoal;

$\mathrm{V}$ - concessões de aposentadorias, reformas e pensões;

VI - representações.

Art. 138. Os presidentes das câmaras terão sempre direito a voto e relatarão os processos que lhes forem distribuídos.

Art. 139. Caso ocorra empate nas votações das câmaras, o processo será submetido à deliberação do Plenário, salvo se tratar de matéria relacionada no inciso VII do art. 17, caso em que se observará a mesma solução dada nos $\S \S 1^{\circ}, 2^{\circ}$ e $3^{\circ}$ do art. 124.

Parágrafo único. (Revogado)

Art. 140. As câmaras obedecerão, no que couber, às normas relativas ao Plenário.

\section{CAPÍTULO III}




\section{PAUTAS DO PLENÁRIO E DAS CÂMARAS}

Art. 141. As pautas das sessões ordinárias e das extraordinárias serão organizadas pela unidade responsável pelo seu secretariado, sob a supervisão do Presidente do respectivo colegiado, observadas a ordem de antiguidade dos relatores e a forma de apreciação dos processos.

$\S 1^{\circ}$ Até as 14 horas do terceiro dia útil anterior à realização da respectiva sessão, os gabinetes dos relatores deverão fornecer à unidade referida no caput, preferencialmente mediante sistema informatizado, as informações relativas aos processos que constituirão a pauta do relator e, se houver, dos revisores, observadas a forma de apreciação - por Relação ou unitária - e, para os processos apreciados de forma unitária, as classes.

$\S 2^{\circ}$ As pautas das sessões serão disponibilizadas pela unidade referida no caput, preferencialmente em meio eletrônico, no terceiro dia útil antecedente às sessões, aos gabinetes dos ministros, dos ministros-substitutos e do representante do Ministério Público junto ao Tribunal.

$\S 3^{\circ}$ As pautas das sessões serão divulgadas mediante a afixação em local próprio e acessível do edifício-sede do Tribunal, a publicação nos órgãos oficiais e a disponibilização no Portal do TCU na internet, até quarenta e oito horas antes da sessão.

$\S 4^{\circ}$ A divulgação da pauta ou de seu aditamento no Portal do TCU na internet e em excerto do Boletim do Tribunal de Contas da União, com a antecedência de até quarenta e oito horas da Sessão, suprirá a ausência de publicação nos órgãos oficiais.

$\S 5^{\circ}$ Para efeito de classificação, os processos a serem apreciados de forma unitária serão divididos em dois grupos, mas essa informação não constará da pauta nem será tornada pública antes do julgamento. Os grupos são assim constituídos:

I - Grupo I: processos em que o relator acolhe em seu voto as conclusões dos pareceres coincidentes do titular da unidade técnica e do representante do Ministério Público, ou do único parecer emitido por um deles;

II - Grupo II: processos em que o relator discorda das conclusões de pelo menos um dos pareceres ou do único parecer emitido, bem como aqueles que não contêm parecer.

$\S 6^{\circ}$ Os processos classificados no Grupo I somente serão apreciados de forma unitária se, a juízo do relator, não puderem ser adotadas, por despacho, as medidas saneadoras previstas no art. 157, ou não puder constar de Relação para votação na forma do art. 143.

$\S 7^{\circ}$ Serão disponibilizados em meio eletrônico pelo gabinete do relator, com antecedência mínima de dois dias úteis da sessão de julgamento e apreciação dos processos, ao Presidente, aos ministros, aos ministros-substitutos, ao representante do Ministério Público e à unidade referida no caput, os arquivos com as minutas de acórdãos relativos aos processos constantes de Relação, bem como os relatórios e, facultativamente, os votos e as minutas dos acórdãos referentes a processos a serem apreciados de forma unitária.

$\S 8^{\circ}$ Ressalvado o disposto no $\S 9^{\circ}$, as Relações e os processos cujos relatórios não forem enviados eletronicamente à unidade referida no caput, no prazo previsto no $\S 7^{\circ}$, serão automaticamente excluídos da pauta e incluídos na pauta da sessão seguinte.

$\S 9^{\circ} \mathrm{O}$ relator que necessite incluir processos em pauta ou disponibilizar relatórios ou arquivos das Relações de processos fora dos prazos previstos nos $\S \S 1^{\circ}$ e $7^{\circ}$, respectivamente, encaminhará justificativa à Presidência do colegiado competente, para deliberação.

$\S 10$ A inclusão em pauta fora do prazo previsto no $\S 1^{\circ}$, ressalvadas as hipóteses do $\S 14$, somente será deferida se for possível a publicação de seu aditamento em órgão oficial, até quarenta e oito horas antes da sessão, e a disponibilização no Portal do TCU na internet, com essa mesma antecedência. 
$\S 11$. As eventuais substituições no conteúdo dos relatórios, votos, acórdãos, pareceres e projetos, inclusive daqueles referentes a processos constantes de Relação, procedidas pelo relator após o vencimento do prazo, deverão ser distribuídas eletronicamente aos destinatários mencionados no $\S 7^{\circ}$, com a indicação de que se trata de alteração, bem assim da data e da hora em que foi efetivada.

$\S 12$ Caso a alteração tratada no parágrafo anterior implique modificação de mérito da proposta original, esta circunstância deverá ser expressamente consignada quando do envio da substituição.

$\S 13$ Será observado o disposto no $\S 7^{\circ}$ quanto ao arquivo de projeto ou proposta, com a respectiva justificação, quando se tratar de enunciado de Súmula, instrução normativa, resolução ou decisão normativa.

$\S 14$ Prescinde de publicação em órgão oficial a inclusão em pauta de processos:

I - em que se esteja propondo a adoção de medida cautelar ou a realização de audiência da parte antes daquela providência;

II - que tratem da aprovação de atos normativos;

III - administrativos, se assim requerido pelo interessado; e

IV - que tratem de solicitação de informações ou de cópia dos autos efetuada pelo Congresso Nacional, na forma do inciso II do art. 159.

$\mathrm{V}$ - em que se esteja julgando embargos declaratórios ou agravo.

Art. 142. Excluir-se-á processo da pauta mediante requerimento do relator ou revisor, no caso de o pedido de vista ter sido feito com base no art. 119, endereçado ao Presidente, que dará conhecimento ao respectivo colegiado por meio de anotação na pauta disponibilizada em meio eletrônico, ressalvado o disposto no parágrafo único do art. 130.

Parágrafo único. A exclusão de processo da pauta durante a sessão deverá ser solicitada oralmente, pelo relator, ou pelo revisor no caso de o pedido de vista ter sido feito com base no art. 119.

\section{CAPÍTULO IV \\ PROCESSOS CONSTANTES DE RELAÇÃO}

Art. 143. A critério do relator poderão ser submetidos, mediante Relação, ao Plenário e às câmaras, observadas as respectivas competências, os processos:

I - de prestação ou tomada de contas, inclusive especial, cuja proposta de deliberação:

a) acolher os pareceres convergentes do titular da unidade técnica e do representante do Ministério Público, desde que se tenham pronunciado pela regularidade, pela regularidade com ressalva, pela quitação ao responsável ou pelo trancamento;

b) acolher um dos pareceres que, mesmo divergentes, não concluam pela irregularidade;

c) acolher pareceres convergentes dos quais conste proposta de rejeição das alegações de defesa ou de irregularidade, desde que o valor de ressarcimento, acrescido dos encargos legais, seja igual ou inferior ao valor fixado pelo Tribunal, a partir do qual a tomada de contas especial deverá ser imediatamente encaminhada para julgamento, observado o disposto no $\S 3^{\circ}$;

d) for pela regularidade ou regularidade com ressalva nos processos em que se levantar o estado de diferimento, nos termos do parágrafo único do art. 195;

II - de admissão e concessão de aposentadoria, reforma ou pensão cuja proposta de deliberação acolher os pareceres convergentes do titular da unidade técnica e do representante do Ministério Público, desde que se tenham pronunciado pela legalidade, ou, ainda que tenham sido pela ilegalidade, tratem exclusivamente de questão jurídica de solução já compendiada na Súmula da Jurisprudência; 
III - referentes a auditorias e inspeções, exceto as mencionadas no $\S 4^{\circ}$, e outras matérias relativas a fiscalização de atos sujeitos a registro e de atos e contratos em que o relator esteja de acordo com as conclusões do servidor responsável pela análise do processo, ou, quando houver, da equipe de fiscalização, e com os pareceres das chefias da unidade técnica e do Ministério Público, se existente,

desde que estes não concluam pela ocorrência de ilegalidade ou irregularidade;

IV - em que se apreciem recursos cuja proposta de deliberação acolher pareceres convergentes da unidade técnica e do Ministério Público, quando existente, que concluírem pelo:

a) conhecimento e provimento total, quando a decisão recorrida tiver sido adotada em processos incluídos em Relação;

b) não conhecimento, observado o disposto no $\S 3^{\circ}$;

$\mathrm{V}$ - em que o relator acolha pareceres convergentes ou, na inexistência destes, formule proposta de deliberação acerca das seguintes matérias:

a) apensamento ou arquivamento de processos;

b) pedido de recolhimento parcelado de dívida que, se denegatório, observará o disposto no $\S$ $3^{\mathrm{o}}$;

c) adoção de medida saneadora;

d) correção de erro material;

e) pedido de prorrogação de prazo fixado pelo Tribunal que, se denegatório, observará o disposto no $\S 3^{\circ}$;

f) não conhecimento de embargos de declaração, observado o disposto no $\S 3^{\circ}$;

g) conversão de processo em tomada de contas especial.

$\S 1^{\circ}$ Qualquer ministro, ministro-substituto convocado ou o representante do Ministério Público poderá requerer destaque de processo constante de Relação, para deliberação em separado.

$\S 2^{\circ}$ Os processos julgados ou apreciados consoante o rito previsto neste artigo receberão, no gabinete do relator, a devida formalização do acórdão proferido, nos termos estabelecidos em ato normativo.

$\S 3^{\circ} \mathrm{O}$ acórdão proferido em processos constantes de Relação, em que haja deliberação pela rejeição das alegações de defesa, pela irregularidade de contas, pelo não conhecimento de recurso ou pela denegação de pedido de recolhimento parcelado de dívida ou de prorrogação de prazo, ou, ainda, pela

ilegalidade do ato de admissão ou concessão previsto na parte final do inciso II deste artigo, conterá os considerandos nos quais estarão descritos todos os elementos e fatos indispensáveis ao juízo de mérito.

$\S 4^{\circ}$ Não poderão constar de Relação os processos que tratem de:

I - proposta de aplicação de multa;

II - proposta de fixação de entendimento prevista no art. 16 , inciso $\mathrm{V}$, de determinação de caráter normativo, de suspensão de pagamentos de parcelas de vencimentos, proventos e benefícios e de estudos sobre procedimentos técnicos;

III - solicitação de qualquer natureza oriunda do Congresso Nacional, de suas casas ou comissões;

IV - auditoria, inspeção ou acompanhamento realizado por solicitação do Congresso Nacional; V - auditoria, inspeção ou acompanhamento de obra pública determinado pela lei de diretrizes orçamentárias ou pela lei orçamentária anual da União;

VI - obra pública incluída em plano de fiscalização;

VII - auditoria operacional;

VIII - auditoria ou inspeção classificada no Grupo II, na forma do $\S 5^{\circ}$ do art. 141 .

$\S 5^{\circ}$ - revogado. 
$\S 6^{\circ}$ A inclusão em Relação de processo de que trata a alínea d do inciso I do caput dar-se-á até o dia $1^{\circ}$ de dezembro do exercício seguinte ao da apresentação das contas.

\title{
TÍTULO V \\ PROCESSO EM GERAL \\ CAPÍTULO I \\ PARTES
}

Art. 144. São partes no processo o responsável e o interessado.

$\S 1^{\circ}$ Responsável é aquele assim qualificado, nos termos da Constituição Federal, da Lei Orgânica do Tribunal de Contas da União e respectiva legislação aplicável.

$\S 2^{\circ}$ Interessado é aquele que, em qualquer etapa do processo, tenha reconhecida, pelo relator ou pelo Tribunal, razão legítima para intervir no processo.

Art. 145. As partes podem praticar os atos processuais diretamente ou por intermédio de procurador regularmente constituído, ainda que não seja advogado.

$\S 1^{\circ}$ Constatado vício na representação da parte, o relator fixará prazo de dez dias para que o responsável ou interessado promova a regularização, sob pena de serem tidos como inexistentes os atos praticados pelo procurador.

$\S 2^{\circ}$ Não se aplica o disposto no final do parágrafo anterior ao caso de juntada de documentos que efetivamente contribuam na busca da verdade material.

$\S 3^{\circ}$ Nos atos processuais, é suficiente a indicação do nome de um dos procuradores, quando a parte houver constituído mais de um ou o constituído substabelecer a outro com reserva de poderes.

$\S 4^{\circ}$ Poderá a parte indicar o procurador em cujo nome serão feitas as notificações, observado o $\S 7^{\circ}$ do art. 179 .

\section{CAPÍTULO II \\ INGRESSO DE INTERESSADO EM PROCESSO}

Art. 146. A habilitação de interessado em processo será efetivada mediante o deferimento, pelo relator, de pedido de ingresso formulado por escrito e devidamente fundamentado.

$\S 1^{\circ} \mathrm{O}$ interessado deverá demonstrar em seu pedido, de forma clara e objetiva, razão legítima para intervir no processo.

$\S 2^{\circ} \mathrm{O}$ relator indeferirá o pedido que não preencher os requisitos do parágrafo anterior.

$\S 3^{\circ}$ É facultado ao interessado, na mesma oportunidade em que solicitar sua habilitação em processo, requerer a juntada de documentos e manifestar a intenção de exercitar alguma faculdade processual.

$\S 4^{\circ}$ Ao deferir o ingresso de interessado no processo, o relator fixará prazo de até quinze dias, contado da ciência do requerente, para o exercício das prerrogativas processuais previstas neste Regimento, caso o interessado já não as tenha exercido.

$\S 5^{\circ} \mathrm{O}$ pedido de habilitação de que trata este artigo será indeferido quando formulado após a inclusão do processo em pauta.

$\S 6^{\circ}$ Quando o ingresso de interessado ocorrer na fase de recurso, observar-se-á o disposto no art. 282.

\author{
CAPÍTULO III \\ DISTRIBUIÇÃO
}


Art. 147. A distribuição de processos aos ministros e ministros-substitutos obedecerá aos princípios da publicidade, da alternatividade e do sorteio.

Art. 148. Para efeito da realização do sorteio, as unidades administrativas dos Poderes Legislativo, Executivo e Judiciário, as entidades da administração indireta, incluídas as fundações instituídas e mantidas pelo poder público federal, e outras unidades que, por determinação normativa, estejam sujeitas à jurisdição do Tribunal, serão agrupadas em listas de unidades jurisdicionadas.

Parágrafo único. As listas referidas no caput serão organizadas sob a coordenação do Presidente e, depois de aprovadas pelo Plenário, publicadas no Boletim do Tribunal de Contas da União.

Art. 149. Para os fins de distribuição de processos concernentes a recursos federais repassados por força de lei ou mediante convênio, acordo, ajuste ou outros instrumentos congêneres, os órgãos e entidades governamentais dos estados, do Distrito Federal e dos municípios equiparam-se às unidades jurisdicionadas e serão incluídos nas listas de que trata o artigo anterior.

Parágrafo único. Aplica-se também o critério previsto neste artigo quanto aos processos referentes a recursos federais transferidos a entidade privada ou pessoa física domiciliada, por ocasião da constituição do processo, na área do respectivo estado ou Distrito Federal.

Art. 150. Na primeira sessão ordinária do Plenário do mês de julho, nos anos pares, o Presidente sorteará, para vigência a partir do primeiro dia do ano subsequente, entre os ministros e os ministros-substitutos, na forma estabelecida em ato normativo, o relator de cada lista de unidades jurisdicionadas, ao qual serão distribuídos todos os processos que derem entrada ou se formarem no Tribunal ao longo do biênio, salvo os mencionados no art. 154.

Parágrafo único. Em observância ao princípio da alternatividade, o ministro ou o ministrosubstituto não poderá ser contemplado com a mesma lista no biênio subsequente.

Art. 151. A composição das listas não poderá ser alterada durante o biênio de vigência do sorteio, exceto nas hipóteses de:

I - criação, fusão, incorporação, cisão, desestatização, desmembramento, extinção ou alteração de vinculação organizacional ou sistêmica de unidades jurisdicionadas;

II - impedimento do relator, atinente a determinado órgão ou entidade;

III - consolidação de processos de prestação ou de tomada de contas, determinada pelo Tribunal como medida de racionalização administrativa;

IV - criação, desmembramento ou fusão de estado ou território federal.

Parágrafo único. O ministro ou ministro-substituto deverá declarar o seu impedimento nas hipóteses dos incisos VIII e IX do art. 39, podendo ainda alegar suspeição, por motivo íntimo.

Art. 152. Caberão ao Presidente cujo mandato se encerrar as listas e os processos anteriormente sorteados para seu sucessor.

Art. 153. Na hipótese de o relator deixar o Tribunal, as listas e os processos que lhe cabiam por sorteio serão redistribuídos àquele que o suceder no cargo.

Art. 154. O Presidente sorteará, entre os ministros, relator de cada processo referente a:

I - recursos de reconsideração e de revisão e pedido de reexame interpostos às deliberações das câmaras ou do Plenário;

II - auditorias a serem coordenadas diretamente por ministros, com a sua participação na execução;

III - projetos de atos normativos;

IV - assuntos que não ensejem a distribuição segundo os critérios previstos nos arts 148 e 149. Parágrafo único. Não participará do sorteio o ministro que tiver proferido o voto condutor do acórdão objeto dos recursos previstos no inciso I, observadas as competências do Plenário e das câmaras. 
Art. 155. Na primeira sessão ordinária do Plenário do mês de julho, o Presidente sorteará, entre os ministros, o relator das Contas do Presidente da República, relativas ao exercício subsequente, a serem apreciadas pelo Tribunal nos termos dos arts. 221 a 229.

$\S 1^{\circ}$ No caso de impedimento do ministro sorteado, ou se ocorrer a impossibilidade do desempenho dessas funções, reconhecida pelo Plenário, será realizado novo sorteio.

$\S 2^{\circ}$ Os nomes dos relatores sorteados serão excluídos dos sorteios seguintes até que todos os demais ministros tenham sido contemplados em iguais condições, exceto na hipótese de que trata o parágrafo anterior.

$\S 3^{\circ}$ Em observância ao princípio da alternatividade, o ministro por último sorteado não será incluído no sorteio seguinte.

\section{CAPÍTULO IV \\ ETAPAS DO PROCESSO, INSTRUÇÃO E TRAMITAÇÃO}

Art. 156. São etapas do processo a instrução, o parecer do Ministério Público e o julgamento ou a apreciação.

$\S 1^{\circ} \mathrm{Na}$ etapa da instrução, aplica-se aos servidores o disposto no inciso VIII do art. 39.

$\S 2^{\circ}$ Aplicam-se aos recursos, no que couber, o disposto no caput e no parágrafo anterior.

Art. 157. O relator presidirá a instrução do processo, determinando, mediante despacho, de ofício ou por provocação da unidade de instrução ou do Ministério Público junto ao Tribunal, o sobrestamento do julgamento ou da apreciação, a citação, a audiência dos responsáveis, ou outras providências consideradas necessárias ao saneamento dos autos.

$\S 1^{\circ} \mathrm{O}$ relator poderá, mediante portaria, delegar competência a titular de unidade técnica, para realização de citação, audiência, diligência e outras providências necessárias ao saneamento do processo.

$\S 2^{\circ}$ A delegação de competência a que se refere o parágrafo anterior, no caso de citação e audiência, poderá, a critério do relator, ter seu alcance restringido a responsáveis ou a valores indicados no instrumento de delegação.

$\S 3^{\circ} \mathrm{O}$ titular de unidade técnica poderá delegar competência, de forma irrestrita ou não, aos diretores de divisão, para encaminhamento dos autos após instrução e parecer.

$\S 4^{\circ} \mathrm{O}$ relator, ou seu sucessor, permanece vinculado ao processo, mesmo após prolatada a deliberação, exceto nos casos de recurso que ensejem sorteio de novo relator, bem como ao respectivo processo de cobrança executiva, quando houver.

$\S 5^{\circ}$ Os atos do processo poderão se dar por meio eletrônico, na forma a ser disciplinada em ato normativo.

$\S 6^{\circ}$ A critério do relator e mediante delegação em portaria específica, o chefe de seu gabinete poderá efetuar despachos de mero expediente ou de simples encaminhamento de processos.

Art. 158. Os atos relativos a despesas de natureza reservada legalmente autorizadas terão tramitação sigilosa.

Art. 159. Consideram-se urgentes, e nessa qualidade terão tramitação preferencial, os documentos e processos referentes a:

I - solicitação de realização de auditorias e inspeções formulada pelo Congresso Nacional, por qualquer de suas casas ou pelas respectivas comissões;

II - solicitação de informações e requisição de resultados de auditorias e inspeções, bem assim de pronunciamento conclusivo, a ser emitido no prazo de trinta dias do recebimento, nos termos dos incisos III, IV e V do art. $1^{\circ}$;

III - pedido de informação para instrução de mandado de segurança ou outro feito judicial;

IV - consulta que, pela sua natureza, exija imediata solução, a critério do relator; 
V - denúncia ou representação que indique a ocorrência de fato grave, a critério do relator;

VI - medidas cautelares;

VII - caso em que o retardamento possa representar significativo dano ao erário;

VIII - recursos previstos neste Regimento que tenham efeito suspensivo;

IX - outros assuntos que, a critério do Plenário ou do Presidente, sejam entendidos como urgentes.

\section{CAPÍTULO V \\ APRESENTAÇÃO DE ALEGAÇÕES DE DEFESA, DE RAZÕES DE JUSTIFICATIVA E DE DOCUMENTOS NOVOS}

Art. 160. As alegações de defesa e as razões de justificativa serão admitidas dentro do prazo determinado na citação ou na audiência.

$\S 1^{\circ}$ Desde a constituição do processo até o término da etapa de instrução, é facultada à parte a juntada de documentos novos.

$\S 2^{\circ}$ Considera-se terminada a etapa de instrução do processo no momento em que o titular da unidade técnica emitir seu parecer conclusivo, sem prejuízo do disposto no $\S 3^{\circ}$ do art. 157 .

$\S 3^{\circ} \mathrm{O}$ disposto no $\S 1^{\circ}$ não prejudica o direito da parte de distribuir, após a inclusão do processo em pauta, memorial aos ministros, ministros-substitutos e ao representante do Ministério Público.

Art. 161. Havendo mais de um responsável pelo mesmo fato, a defesa apresentada por um deles aproveitará a todos, mesmo ao revel, no que concerne às circunstâncias objetivas, e não aproveitará no tocante aos fundamentos de natureza exclusivamente pessoal.

\section{CAPÍTULO VI \\ PROVAS}

Art. 162. As provas que a parte quiser produzir perante o Tribunal devem sempre ser apresentadas de forma documental, mesmo as declarações pessoais de terceiros.

$\S 1^{\circ}$ São inadmissíveis no processo provas obtidas por meios ilícitos.

$\S 2^{\circ} \mathrm{O}$ relator, em decisão fundamentada, negará a juntada de provas ilícitas, impertinentes, desnecessárias ou protelatórias.

\section{CAPÍTULO VII \\ PEDIDO DE VISTA E DE CÓPIA DOS AUTOS}

Art. 163. As partes poderão pedir vista ou cópia de peça do processo, mediante solicitação dirigida ao relator, segundo os procedimentos previstos neste capítulo.

$\S 1^{\circ} \mathrm{Na}$ ausência ou impedimento por motivo de licença, férias, recesso do Tribunal ou outro afastamento legal do relator ou do seu substituto, e não havendo delegação de competência na forma do art. 164, caberá ao Presidente do Tribunal decidir sobre os pedidos previstos no caput. $\S 2^{\circ}$ Poderão ser indeferidos os pedidos de que trata o caput se existir motivo justo ou, estando no dia de julgamento do processo, não houver tempo suficiente para a concessão de vista ou extração de cópias.

$\S 3^{\circ}$ No caso de processo encerrado, exceto por apensamento a processo em aberto, caberá à Presidência do Tribunal decidir sobre os pedidos previstos no caput.

$\S 4^{\circ}$ Do despacho que indeferir pedido de vista ou cópia de peça de processo cabe agravo, na forma do art. 289. 
Art. 164. O relator, mediante portaria, poderá delegar competência aos titulares das unidades técnicas e ao chefe de seu gabinete, bem como aos dos membros do Ministério Público, para autorização de pedido de vista e de fornecimento de cópia de processo.

Art. 165. O despacho que deferir o pedido de vista indicará o local onde os autos poderão ser examinados.

$\S 1^{\circ}$ As partes não poderão retirar processo das dependências do Tribunal, exceto por intermédio de advogado regularmente constituído, que poderá fazê-lo pelo prazo de cinco dias, sob a sua responsabilidade, na forma e nas condições definidas em ato normativo.

$\S 2^{\circ}$ Se o processo, retirado das dependências do Tribunal, não for devolvido dentro do prazo prescrito no parágrafo anterior, o relator determinará a reconstituição das peças que entender necessárias ao julgamento, que em caso de revelia da parte poderá ter por fundamento exclusivamente as conclusões da unidade técnica.

Art. 166. Deferido o pedido, para o recebimento de cópias, a parte deverá apresentar comprovante do recolhimento da importância correspondente ao ressarcimento dos custos.

$\S 1^{\circ} \mathrm{O}$ pagamento será dispensado nas solicitações de interesse de órgão ou entidade da administração pública federal, estadual ou municipal.

$\S 2^{\circ}$ Poderá ser fornecida cópia de processo, julgado ou não, mesmo de natureza sigilosa, ressalvados os documentos e informações protegidos por sigilo fiscal, bancário, comercial ou outros previstos em lei, a dirigente que comprove, de forma objetiva, a necessidade das informações para defesa do órgão ou entidade federal, estadual ou municipal.

$\S 3^{\circ}$ Constará registro do caráter reservado das informações em cada cópia de processo de natureza sigilosa a ser fornecida.

Art. 167. Não será concedida vista ou fornecida cópia de peças da etapa de instrução antes do seu término, observado o disposto no $\S 2^{\circ}$ do art. 160.

\section{CAPÍTULO VIII SUSTENTAÇÃO ORAL}

Art. 168. No julgamento ou apreciação de processo, ressalvada a hipótese prevista no $\S 9^{\circ}$, as partes poderão produzir sustentação oral, após a apresentação, ainda que resumida, do relatório e antes da leitura do voto resumido do relator, pessoalmente ou por procurador devidamente constituído, desde que a tenham requerido ao Presidente do respectivo colegiado até quatro horas antes do início da sessão, cabendo ao referido Presidente autorizar, excepcionalmente, a produção de sustentação oral nos casos em que houver pedido fora do prazo estabelecido.

$\S 1^{\circ} \mathrm{O}$ requerimento da parte será apreciado pelo Presidente do respectivo colegiado, devendo ser dada ciência da respectiva decisão ao dirigente da unidade responsável pelo secretariado das sessões.

$\S 2^{\circ}$ Se houver solicitação da parte interessada na sustentação oral, poderá o relator autorizá-la a obter cópia do relatório antes da sessão, fato que dispensará a sua apresentação por ocasião do julgamento, sendo facultado à parte dispensá-la em qualquer hipótese.

$\S 3^{\circ}$ Após o pronunciamento, se houver, do representante do Ministério Público, a parte ou seu procurador falará uma única vez e sem ser interrompida, pelo prazo de dez minutos, podendo o Presidente do colegiado, ante a maior complexidade da matéria, prorrogar o tempo por até igual período, se previamente requerido.

$\S 4^{\circ}$ No caso de procurador de mais de uma parte, aplica-se o prazo previsto no parágrafo anterior.

$\S 5^{\circ}$ Se no mesmo processo houver interesses opostos, observar-se-á, relativamente a cada parte, o disposto nos parágrafos anteriores quanto aos prazos para sustentação oral. 
$\S 6^{\circ}$ Havendo mais de uma parte com procuradores diferentes, o prazo previsto no $\S 3^{\circ}$ será duplicado e dividido em frações iguais entre estes, observada a ordem cronológica dos requerimentos.

$\S 7^{\circ}$ Quando se tratar de julgamento ou apreciação de processo em sessão de caráter reservado, as partes e seus procuradores terão acesso à Sala das Sessões ao iniciar-se a apresentação do relatório e dela deverão ausentar-se ao ser concluído o seu exame.

$\S 8^{\circ}$ Durante a discussão e o julgamento, por solicitação de ministro, ministro-substituto ou representante do Ministério Público, poderá ser concedida a palavra à parte ou a seu procurador para estrito esclarecimento de matéria de fato.

$\S 9^{\circ}$ Não se admitirá sustentação oral no julgamento ou apreciação de consulta, embargos de declaração, agravo e medida cautelar.

\section{CAPÍTULO IX ARQUIVAMENTO DE PROCESSO}

Art. 169. O processo será encerrado no sistema informatizado de controle de processos, mediante despacho do dirigente da unidade técnica, nas seguintes situações:

I - quando houver decisão do relator ou de colegiado pelo apensamento definitivo a outro processo;

II - quando houver decisão do relator, de colegiado ou da Presidência pelo seu encerramento, após efetuadas as comunicações determinadas e expirados os prazos dos recursos cabíveis dotados de efeito suspensivo;

III - nos casos de decisões definitivas ou terminativas, após a adoção das providências nelas determinadas e a efetivação das competentes comunicações;

IV - após o registro de que trata o art. 259 do Regimento Interno;

$\mathrm{V}$ - nos casos em que o processo tenha cumprido o objetivo para o qual foi constituído;

VI - nos casos previstos nos arts. 212, 213, 235, parágrafo único, 263 e 265;

$\S 1^{\circ} \mathrm{O}$ encerramento do processo com fundamento nos incisos I e $\mathrm{V}$ deste artigo deverá ser precedido de ciência aos interessados dos motivos determinantes.

$\S 2^{\circ} \mathrm{O}$ encerramento do processo implicará o apensamento dos autos a outro processo, no caso do inciso I, ou, no caso de processo físico, o arquivamento dos autos na unidade técnica competente.

Art. 170. O Tribunal disciplinará, em ato normativo, os procedimentos de guarda, gerenciamento, preservação e consulta de autos de processo.

Parágrafo único. Nos processos em que seja cabível a interposição de recurso nas situações indicadas no $\S 2^{\circ}$ do art. 285 , observado o parágrafo único do art. 286 , e no caput do art. 288 , o prazo de guarda, gerenciamento, preservação e consulta dos autos será de, no mínimo, seis anos, a contar do trânsito em julgado.

\section{CAPÍTULO X NULIDADES}

Art. 171. Nenhum ato será declarado nulo se do vício não resultar prejuízo para a parte, para o erário, para a apuração dos fatos pelo Tribunal ou para a deliberação adotada.

Parágrafo único. Quando puder decidir do mérito a favor da parte a quem aproveitaria a declaração de nulidade, o Tribunal não a pronunciará nem mandará repetir o ato ou suprir-lhe a falta. 
Art. 172. Não se tratando de nulidade absoluta, considerar-se-á válido o ato que, praticado de outra forma, tiver atingido o seu fim.

Parágrafo único. O disposto neste artigo não impede o suprimento da nulidade absoluta, nas hipóteses previstas neste Regimento e nas leis processuais aplicáveis subsidiariamente aos processos do Tribunal.

Art. 173. A parte não poderá arguir nulidade a que haja dado causa ou para a qual tenha, de qualquer modo, concorrido.

Art. 174. Conforme a competência para a prática do ato, o Tribunal ou o relator declarará a nulidade de ofício, se absoluta, ou por provocação da parte ou do Ministério Público junto ao Tribunal, em qualquer caso.

Art. 175. A nulidade do ato, uma vez declarada, causará a dos atos subsequentes que dele dependam ou sejam consequência.

Parágrafo único. A nulidade de uma parte do ato, porém, não prejudicará as outras que dela sejam independentes.

Art. 176. O relator ou o Tribunal, ao pronunciar a nulidade, declarará os atos a que ela se estende, ordenando as providências necessárias, a fim de que sejam repetidos ou retificados, ressalvado o disposto no art. 171.

Parágrafo único. Pronunciada a nulidade na fase recursal, compete:

I - ao relator do recurso ou ao Tribunal declarar os atos a que ela se estende;

II - ao ministro ou ministro-substituto, sob cuja relatoria o ato declarado nulo foi praticado, ou ao seu sucessor, ordenar as providências necessárias para a repetição ou retificação do ato.

Art. 177. Eventual incompetência do relator não é causa de nulidade dos atos por ele praticados. Art. 178. Nos processos em que deva intervir, a falta de manifestação do Ministério Público implica a nulidade do processo a partir do momento em que esse órgão deveria ter-se pronunciado.

Parágrafo único. A manifestação posterior do Ministério Público sana a nulidade do processo, se ocorrer antes da decisão definitiva de mérito do Tribunal, nas hipóteses em que expressamente anuir aos atos praticados anteriormente ao seu pronunciamento.

\section{CAPÍTULO XI COMUNICAÇÕES}

Art. 179. A citação, a audiência ou a notificação, bem como a comunicação de diligência e de rejeição de alegações de defesa, far-se-ão:

I - mediante ciência da parte, efetivada por servidor designado, por meio eletrônico, fac-símile, telegrama ou qualquer outra forma, desde que fique confirmada inequivocamente a entrega da comunicação ao destinatário;

II - mediante carta registrada, com aviso de recebimento que comprove a entrega no endereço do destinatário;

III - por edital publicado nos órgãos oficiais, quando o seu destinatário não for localizado.

$\S 1^{\circ}$ A citação, a audiência, a comunicação de diligência ou a notificação determinada, conforme o caso, pelo relator, pelo Presidente, pelas câmaras ou pelo Plenário será expedida pela unidade técnica competente da Secretaria do Tribunal.

$\S 2^{\circ}$ No caso de adoção de medida cautelar pelo Tribunal, pelo Presidente, ou pelos relatores, as comunicações poderão ser efetivadas pelo meio mais célere possível, entre os previstos no inciso I do caput, observado o $\S 4^{\circ}$ do art. 276.

$\S 3^{\circ}$ As notificações ao responsável para pagamento de débito ou de multa, efetivadas nas formas previstas nos incisos I e II do caput, serão acompanhadas de cópia do documento de 
arrecadação, devidamente preenchido com dados que não sofrerão modificações até a data indicada.

$\S 4^{\circ}$ Supre a falta da citação ou da audiência o comparecimento espontâneo do responsável, desde que havido após a determinação do Tribunal ou do relator prevista no inciso II ou III do art. 202.

$\S 5^{\circ}$ Ato normativo próprio do Tribunal disciplinará a elaboração, a expedição e o controle de entrega das comunicações.

$\S 6^{\circ}$ Estão abrangidas no conceito de audiência as comunicações processuais da oitiva prevista no art. 250, inciso $\mathrm{V}$, e no conceito de notificação, todas as comunicações processuais não caracterizadas por citação, audiência ou diligência.

$\S 7^{\circ}$ Quando a parte for representada por advogado, a comunicação deve ser dirigida ao representante legalmente constituído nos autos.

\section{CAPÍTULO XII CERTIDÕES E PRESTAÇÃO DE INFORMAÇÕES}

Art. 180. As certidões ou informações requeridas ao Tribunal por pessoa física ou jurídica, para defesa de seus direitos ou esclarecimentos de interesse particular, coletivo ou geral, serão expedidas pela Presidência, ou pelos dirigentes das unidades técnicas, mediante delegação, no prazo máximo de quinze dias a contar da autuação do requerimento.

$\S 1^{\circ}$ Os requerimentos serão instruídos em caráter prioritário pelas unidades competentes, considerando os julgados do Tribunal, o cadastro de responsáveis por contas julgadas irregulares, bem como outras fontes subsidiárias, encaminhando-os à Presidência acompanhados de minuta de certidão.

$\S 2^{\circ}$ A Presidência disciplinará, em ato normativo, a forma de atendimento aos requerimentos referidos neste artigo.

Art. 181. Quando se tratar de matéria cujo sigilo seja considerado pelo Tribunal como imprescindível à segurança da sociedade e do Estado, ou quando a defesa da intimidade e o interesse social o exigirem, o requerente será informado sobre a impossibilidade de atendimento da solicitação.

Art. 182. O denunciante poderá requerer ao Tribunal, mediante expediente dirigido ao Presidente, certidão dos despachos e dos fatos apurados, a qual deverá ser fornecida no prazo máximo de quinze dias, a contar da data da entrada do pedido, desde que o respectivo processo de apuração tenha sido concluído ou arquivado.

$\S 1^{\circ}$ Decorrido o prazo de noventa dias, a contar da data em que a denúncia deu entrada no Tribunal, será obrigatoriamente fornecida a certidão de que trata este artigo, ainda que não estejam concluídas as apurações.

$\S 2^{\circ}$ Ao expedir a certidão prevista no caput e no $\S 1^{\circ}$, deverá o denunciante ser alertado, se for o caso, de que o respectivo processo tramita em caráter sigiloso.

\section{CAPÍTULO XIII PRAZOS}

Art. 183. Os prazos referidos neste Regimento contam-se dia a dia, a partir da data:

I - do recebimento pela parte:

a) da citação ou da comunicação de audiência;

b) da comunicação de rejeição das alegações da defesa;

c) da comunicação de diligência;

d) da notificação; 
II - constante de documento que comprove a ciência da parte;

III - da publicação nos órgãos oficiais, quando a parte não for localizada;

IV - nos demais casos, salvo disposição legal expressa em contrário, da publicação do acórdão no Diário Oficial da União.

Parágrafo único. A prorrogação, quando cabível, contar-se-á a partir do término do prazo inicialmente concedido e independerá de notificação da parte.

Art. 184. Os acréscimos em publicação e as retificações em comunicação, que contiverem informações substanciais capazes de afetar a esfera de direito subjetivo do destinatário, importam em devolução do prazo à parte.

Parágrafo único. A comunicação de mera correção de inexatidão material ou de resultado de julgamento de recurso interposto por outro interessado, observado o disposto no artigo 261, não ensejará restituição de prazo.

Art. 185. Na contagem dos prazos, salvo disposição legal em contrário, excluir-se-á o dia do início e incluir-se-á o do vencimento.

$\S 1^{\circ}$ Atendido o disposto no caput, o prazo começa a correr a partir do primeiro dia em que houver expediente no Tribunal.

$\S 2^{\circ} \mathrm{Se}$ o vencimento recair em dia em que não houver expediente, o prazo será prorrogado até o primeiro dia útil imediato.

Art. 186. Os prazos para interposição de recursos e para apresentação de alegações de defesa, de razões de justificativa, de atendimento de diligência, de cumprimento de determinação do Tribunal, bem como os demais prazos fixados para a parte, em qualquer situação, não se suspendem nem se interrompem em razão do recesso do Tribunal, previsto no art. 68 da Lei $\mathrm{n}^{\circ}$ 8.443, de 1992.

Parágrafo único. Decorrido o prazo fixado para a prática do ato, extingue-se, independentemente de declaração, o direito do jurisdicionado de praticá-lo ou alterá-lo, se já praticado, salvo comprovado justo motivo.

Art. 187. O ato que ordenar diligência assinará prazo para seu cumprimento, findo o qual a matéria poderá ser apreciada, mesmo para a imposição de sanções legais.

Parágrafo único. Se o ato for omisso a respeito, será de quinze dias o prazo para cumprimento de diligência, salvo se existir disposição especial para o caso.

\title{
TÍTULO VI \\ ATIVIDADE DE CONTROLE EXTERNO \\ CAPÍTULO I-A \\ PLANO DE CONTROLE EXTERNO
}

Art. 188-A. As ações de controle externo obedecerão a plano de controle externo, proposto pela Presidência, de acordo com o plano estratégico e as diretrizes do Tribunal e das Contas do Presidente da República.

Parágrafo único. O plano será elaborado em consulta aos relatores das listas de unidades jurisdicionadas e das contas do governo, e será aprovado pelo Plenário em sessão de caráter reservado.

\author{
CAPÍTULO I \\ JULGAMENTO DE CONTAS \\ SEÇÃO I \\ TOMADA E PRESTAÇÃO DE CONTAS
}


Art. 188. Têm o dever de prestar contas e, ressalvado o disposto no inciso XXXV do art. $5^{\circ}$ da Constituição Federal, só por decisão do Tribunal de Contas da União podem ser liberadas dessa responsabilidade, as pessoas indicadas nos incisos I e III a VII do art. $5^{\circ}$ deste Regimento.

Art. 189. As contas dos administradores e responsáveis a que se refere o artigo anterior serão submetidas a julgamento do Tribunal, sob forma de tomada ou prestação de contas, que poderão ser ordinárias, extraordinárias ou especiais.

Parágrafo único. Atos normativos próprios do Tribunal disporão acerca da organização, recebimento e tratamento dos processos de tomadas e prestações de contas a que se refere este artigo.

Art. 190. O órgão de controle interno competente encaminhará ou colocará à disposição do Tribunal, em cada exercício, por meio de acesso a banco de dados informatizado, o rol de responsáveis e suas alterações, com a indicação da natureza da responsabilidade de cada um, além de outros documentos ou informações necessários, na forma prescrita em ato normativo. Art. 191. As contas dos órgãos e fundos indicados no art. 257 deverão ser acompanhadas de demonstrativos que expressem as situações dos projetos e instituições beneficiadas por renúncia de receitas, bem como do impacto socioeconômico de suas atividades.

Art. 192. Salvo disposição legal ou regulamentar em contrário, os processos de tomada ou prestação de contas ordinária deverão ser apresentados ao Tribunal dentro dos prazos definidos no ato normativo de que trata o art. 194.

Art. 193. (Revogado)

Art. 194. Os processos de tomada ou prestação de contas ordinária conterão os elementos e demonstrativos especificados em ato normativo, que evidenciem a boa e regular aplicação dos recursos públicos e, ainda, a observância aos dispositivos legais e regulamentares aplicáveis.

Parágrafo único. $\mathrm{O}$ ato normativo mencionado no caput, tendo em vista a racionalização e a simplificação do exame e do julgamento das tomadas e prestações de contas pelo Tribunal, estabelecerá também critérios de formalização dos respectivos processos, tendo em vista a materialidade dos recursos públicos geridos, a natureza e a importância socioeconômica dos órgãos e entidades.

Art. 195. O Tribunal disciplinará, em ato normativo, procedimentos de análise técnica simplificada, entre os quais o diferimento da instrução de processos de tomada e prestação de contas que contenham parecer do controle interno pela regularidade ou regularidade com ressalva, observados, ainda, critérios de materialidade, relevância e risco.

Parágrafo único. Entende-se por diferimento o sobrestamento da análise do processo na unidade técnica por prazo determinado, findo o qual, inexistindo elementos supervenientes que infirmem o parecer do controle interno, será encaminhado ao relator, após ouvido o Ministério Público, para julgamento por Relação, observado o prazo fixado no $\S 6^{\circ}$ do art. 143 .

Art. 196. O Tribunal disciplinará, em ato normativo, a forma de apresentação das contas a serem prestadas pelo governo de território federal.

\section{SEÇÃO II \\ TOMADA DE CONTAS ESPECIAL}

Art. 197. Diante da omissão no dever de prestar contas, da não-comprovação da aplicação dos recursos repassados pela União na forma prevista no inciso VIII do art. $5^{\circ}$, da ocorrência de desfalque ou desvio de dinheiros, bens ou valores públicos, ou, ainda, da prática de qualquer ato ilegal, ilegítimo ou antieconômico de que resulte dano ao erário, a autoridade administrativa competente, sob pena de responsabilidade solidária, deverá imediatamente adotar providências 
com vistas à instauração de tomada de contas especial para apuração dos fatos, identificação dos responsáveis e quantificação do dano.

$\S 1^{\circ}$ Não providenciado o disposto no caput, o Tribunal determinará a instauração de tomada de contas especial, fixando prazo para cumprimento dessa decisão.

$\S 2^{\circ}$ Esgotadas todas as medidas ao alcance da autoridade administrativa e do órgão do controle interno, visando à apuração dos fatos irregulares, à perfeita identificação dos responsáveis e ao ressarcimento do erário, a tomada de contas especial será encaminhada ao Tribunal para julgamento, observado, quando couber, o art. 206.

$\S 3^{\circ} \mathrm{Na}$ ocorrência de perda, extravio ou outra irregularidade sem que se caracterize a má-fé de quem lhe deu causa, se o dano for imediatamente ressarcido, a autoridade administrativa competente deverá, em sua tomada ou prestação de contas ordinária, comunicar o fato ao Tribunal, ficando dispensada desde logo a instauração de tomada de contas especial.

Art. 198. Os processos de tomadas de contas especiais instauradas por determinação da autoridade administrativa ou do Tribunal deverão conter os elementos especificados em ato normativo, sem prejuízo de outras peças que permitam ajuizamento acerca da responsabilidade ou não pelo dano verificado.

Parágrafo único. O disposto no caput não se aplica aos processos convertidos em tomada de contas especial pelo Tribunal, sendo nesse caso obrigatória, entretanto, a cientificação do ministro de Estado supervisor da área ou autoridade equivalente.

Art. 199. A tomada de contas especial prevista no caput e no $\S 1^{\circ}$ do art. 197 será, desde logo, encaminhada ao Tribunal para julgamento, se o dano ao erário for de valor igual ou superior à quantia fixada em cada ano civil, até a última sessão ordinária do Plenário, para vigorar no exercício subsequente.

$\S 1^{\circ}$ A proposta de fixação da quantia a que se refere o caput será submetida ao Plenário pelo Presidente do Tribunal, mediante projeto de ato normativo.

$\S 2^{\circ}$ Havendo majoração do limite a que se refere o caput, as tomadas de contas especiais de exercícios anteriores já presentes no Tribunal, cujo dano ao erário seja inferior ao novo valor fixado, poderão ser arquivadas, sem cancelamento do débito, na forma indicada no art. 213, desde que ainda não tenha sido efetivada a citação dos responsáveis.

$\S 3^{\circ} \mathrm{Na}$ hipótese do parágrafo anterior, o responsável poderá solicitar ao Tribunal o desarquivamento do processo para julgamento.

$\S 4^{\circ}$ Se o dano for de valor inferior à quantia a que alude o caput, a tomada de contas especial será anexada ao processo da respectiva tomada ou prestação de contas ordinária do administrador ou ordenador de despesa, para julgamento em conjunto.

Art. 200. O Tribunal poderá baixar ato normativo visando simplificar a formalização e o trâmite e agilizar o julgamento das tomadas de contas especiais.

\section{SEÇÃO III DECISÕES}

Art. 201. A decisão em processo de prestação ou de tomada de contas, mesmo especial, pode ser preliminar, definitiva ou terminativa.

$\S 1^{\circ}$ Preliminar é a decisão pela qual o relator ou o Tribunal, antes de pronunciar-se quanto ao mérito das contas, resolve sobrestar o julgamento, ordenar a citação ou a audiência dos responsáveis, rejeitar as alegações de defesa e fixar novo e improrrogável prazo para recolhimento do débito ou, ainda, determinar outras diligências necessárias ao saneamento do processo. 
$\S 2^{\circ}$ Definitiva é a decisão pela qual o Tribunal julga as contas regulares, regulares com ressalva ou irregulares.

$\S 3^{\circ}$ Terminativa é a decisão pela qual o Tribunal ordena o trancamento das contas que forem consideradas iliquidáveis, ou determina o seu arquivamento pela ausência de pressupostos de constituição e de desenvolvimento válido e regular do processo ou por racionalização administrativa e economia processual, nos termos dos arts. 211 a 213.

Art. 202. Verificada irregularidade nas contas, o relator ou o Tribunal:

I - definirá a responsabilidade individual ou solidária pelo ato de gestão inquinado;

II - se houver débito, ordenará a citação do responsável para que, no prazo de quinze dias, apresente alegações de defesa ou recolha a quantia devida, ou ainda, a seu critério, adote ambas as providências;

III - se não houver débito, determinará a audiência do responsável para que, no prazo de quinze dias, apresente razões de justificativa;

IV - adotará outras medidas cabíveis.

$\S 1^{\circ}$ Os débitos serão atualizados monetariamente e, caso o responsável venha a ser condenado pelo Tribunal, serão acrescidos de juros de mora, nos termos da legislação vigente, devendo-se registrar expressamente essas informações no expediente citatório.

$\S 2^{\circ} \mathrm{Na}$ oportunidade da resposta à citação, será examinada a ocorrência de boa-fé na conduta do responsável e a inexistência de outra irregularidade nas contas.

$\S 3^{\circ}$ Comprovados esses requisitos e subsistindo o débito, o Tribunal proferirá, mediante acórdão, deliberação de rejeição das alegações de defesa e dará ciência ao responsável para que, em novo e improrrogável prazo de quinze dias, recolha a importância devida.

$\S 4^{\circ} \mathrm{Na}$ hipótese do parágrafo anterior, a liquidação tempestiva do débito atualizado monetariamente saneará o processo e o Tribunal julgará as contas regulares com ressalva e dará quitação ao responsável.

$\S 5^{\circ} \mathrm{O}$ ofício que der ciência ao responsável da rejeição das alegações de defesa deverá conter expressamente informação sobre o disposto no parágrafo anterior.

$\S 6^{\circ}$ Não reconhecida a boa-fé do responsável ou havendo outras irregularidades, o Tribunal proferirá, desde logo, o julgamento definitivo de mérito pela irregularidade das contas.

$\S 7^{\circ}$ No caso de rejeição das razões de justificativa, a comunicação a que se refere o $\S 3^{\circ}$ do art. 179 será efetivada na mesma oportunidade em que se fizer a notificação da aplicação das sanções previstas nos arts. 268 e 270.

$\S 8^{\circ} \mathrm{O}$ responsável que não atender à citação ou à audiência será considerado revel pelo Tribunal, para todos os efeitos, dando-se prosseguimento ao processo.

Art. 203. A decisão preliminar do relator a que se refere o $\S 1^{\circ}$ do art. 201 poderá, a seu critério, ser publicada nos órgãos oficiais.

Art. 204. O Tribunal julgará as tomadas e prestações de contas até o término do exercício seguinte àquele em que lhe tiverem sido apresentadas.

Art. 205. Ao julgar as contas, o Tribunal decidirá se são regulares, regulares com ressalva ou irregulares.

Art. 206. A decisão definitiva em processo de tomada ou prestação de contas ordinária não constituirá fato impeditivo da aplicação de multa ou imputação de débito em outros processos, salvo se a matéria tiver sido examinada de forma expressa e conclusiva, hipótese na qual o seu exame dependerá do conhecimento de eventual recurso interposto pelo Ministério Público.

$\S 1^{\circ}$ (Revogado)

$\S 2^{\circ}$ (Revogado) 
Art. 207. As contas serão julgadas regulares quando expressarem, de forma clara e objetiva, a exatidão dos demonstrativos contábeis, a legalidade, a legitimidade e a economicidade dos atos de gestão do responsável.

Parágrafo único. Quando julgar as contas regulares, o Tribunal dará quitação plena ao responsável.

Art. 208. As contas serão julgadas regulares com ressalva quando evidenciarem impropriedade ou qualquer outra falta de natureza formal de que não resulte dano ao erário.

$\S 1^{\circ} \mathrm{O}$ acórdão de julgamento deverá indicar, resumidamente, os motivos que ensejam a ressalva das contas.

$\S 2^{\circ} \mathrm{Na}$ hipótese prevista no caput, o Tribunal dará quitação ao responsável e lhe determinará, ou a quem lhe haja sucedido, se cabível, a adoção de medidas necessárias à correção das impropriedades ou faltas identificadas, de modo a prevenir a ocorrência de outras semelhantes. Art. 209. O Tribunal julgará as contas irregulares quando evidenciada qualquer das seguintes ocorrências:

I - omissão no dever de prestar contas;

II - prática de ato de gestão ilegal, ilegítimo ou antieconômico, ou infração a norma legal ou regulamentar de natureza contábil, financeira, orçamentária, operacional ou patrimonial;

III - dano ao erário decorrente de ato de gestão ilegítimo ou antieconômico;

IV - desfalque ou desvio de dinheiros, bens ou valores públicos.

$\S 1^{\circ} \mathrm{O}$ Tribunal poderá julgar irregulares as contas no caso de descumprimento de determinação de que o responsável tenha tido ciência, feita em processo de tomada ou prestação de contas.

$\S 2^{\circ}$ Contas apresentadas em desacordo com as normas legais e regulamentares aplicáveis à matéria poderão ser julgadas regulares com ressalva, desde que se comprove, por outros meios, a boa e regular aplicação dos recursos.

$\S 3^{\circ}$ Contas que não consigam demonstrar por outros meios a boa e regular aplicação dos

recursos poderão ser julgadas irregulares, nos termos do inciso II do caput, sem prejuízo da imputação de débito.

$\S 4^{\circ}$ Citado o responsável pela omissão de que trata o inciso I, bem como instado a justificar essa omissão, a apresentação posterior das contas, sem justificativa para a falta, não elidirá a respectiva irregularidade, podendo o débito ser afastado caso a documentação comprobatória das despesas esteja de acordo com as normas legais e regulamentares e demonstre a boa e regular aplicação dos recursos, sem prejuízo de aplicação da multa prevista no inciso I do art. 268.

$\S 5^{\circ}$ Nas hipóteses dos incisos II, III e IV, o Tribunal, ao julgar irregulares as contas, fixará a responsabilidade solidária:

I - do agente público que praticou o ato irregular; e

II - do terceiro que, como contratante ou parte interessada na prática do mesmo ato, de qualquer modo haja concorrido para o cometimento do dano apurado.

$\S 6^{\circ} \mathrm{A}$ responsabilidade do terceiro de que trata o inciso II do parágrafo anterior derivará:

I - do cometimento de irregularidade que não se limite ao simples descumprimento de obrigações contratuais ou ao não pagamento de títulos de crédito ou;

II - da irregularidade no recebimento de benefício indevido ou pagamento superfaturado.

$\S 7^{\circ}$ Verificadas as ocorrências previstas nos incisos III e IV do caput, o Tribunal, por ocasião do julgamento, determinará a remessa de cópia da documentação pertinente ao Ministério Público da União, para ajuizamento das ações cabíveis, podendo decidir sobre essa mesma providência também nas hipóteses dos incisos I e II.

Art. 210. Quando julgar as contas irregulares, havendo débito, o Tribunal condenará o responsável ao pagamento da dívida, atualizada monetariamente a partir da data da 
irregularidade, acrescida dos juros de mora devidos, podendo, ainda, aplicar-lhe a multa prevista no art. 267.

$\S 1^{\circ}$ A apuração do débito far-se-á mediante:

I - verificação, quando for possível quantificar com exatidão o real valor devido;

II - estimativa, quando, por meios confiáveis, apurar-se quantia que seguramente não excederia o real valor devido.

$\S 2^{\circ}$ Não havendo débito, mas evidenciada qualquer das ocorrências previstas nos incisos I, II

e III do caput e no $\S 3^{\circ}$ do artigo anterior, o Tribunal aplicará ao responsável a multa prevista no inciso I do art. 268.

$\S 3^{\circ}$ Quando não for possível precisar a data do débito com exatidão, far-se-á o seu arbitramento por estimativa, desde que essa providência não desfavoreça o responsável.

Art. 211. As contas serão consideradas iliquidáveis quando caso fortuito ou de força maior, comprovadamente alheio à vontade do responsável, tornar materialmente impossível o julgamento de mérito.

$\S 1^{\circ} \mathrm{Na}$ hipótese prevista neste artigo, o Tribunal ordenará o trancamento das contas e o consequente arquivamento do processo.

$\S 2^{\circ}$ Dentro do prazo de cinco anos contados da publicação, nos órgãos oficiais, da decisão terminativa a que se refere o $\S 3^{\circ}$ do art. 201, o Tribunal poderá, à vista de novos elementos considerados suficientes, autorizar o desarquivamento do processo e determinar que se ultime a respectiva tomada ou prestação de contas.

$\S 3^{\circ}$ Transcorrido o prazo referido no parágrafo anterior sem que tenha havido nova decisão, as contas serão consideradas encerradas, com baixa na responsabilidade do administrador.

Art. 212. O Tribunal determinará o arquivamento do processo de prestação ou de tomada contas, mesmo especial, sem julgamento do mérito, quando verificar a ausência de pressupostos de constituição e de desenvolvimento válido e regular do processo.

Art. 213. A título de racionalização administrativa e economia processual, e com o objetivo de evitar que o custo da cobrança seja superior ao valor do ressarcimento, o Tribunal poderá determinar, desde logo, nos termos de ato normativo, o arquivamento de processo, sem cancelamento do débito, a cujo pagamento continuará obrigado o devedor, para que lhe possa ser dada quitação.

\section{SEÇÃO IV EXECUÇÃO DAS DECISÕES}

Art. 214. A decisão definitiva publicada nos órgãos oficiais constituirá:

I - no caso de contas regulares, certificado de quitação plena do responsável para com o erário; II - no caso de contas regulares com ressalva, certificado de quitação com determinação, se cabível, nos termos do $\S 2^{\circ}$ do art. 208;

III - no caso de contas irregulares:

a) obrigação de o responsável, no prazo de quinze dias, provar, perante o Tribunal, o pagamento da quantia correspondente ao débito que lhe tiver sido imputado ou da multa cominada;

b) título executivo bastante para a cobrança judicial da dívida decorrente do débito ou da multa, se não recolhida no prazo pelo responsável;

c) fundamento para que a autoridade competente proceda à efetivação da sanção e da medida cautelar previstas respectivamente nos art. 270 e 275.

Art. 215. A decisão do Tribunal, de que resulte imputação de débito ou cominação de multa, torna a dívida líquida e certa e tem eficácia de título executivo. 
Art. 216. O responsável será notificado para efetuar e provar o pagamento das dívidas decorrentes de imputação de débito ou cominação de multa.

Art. 217. Em qualquer fase do processo, o Tribunal ou o relator poderá autorizar o pagamento parcelado da importância devida em até trinta e seis parcelas, desde que o processo não tenha sido remetido para cobrança judicial.

$\S 1^{\circ}$ Verificada a hipótese prevista neste artigo, incidirão sobre cada parcela, corrigida monetariamente, os correspondentes acréscimos legais.

$\S 2^{\circ}$ A falta de pagamento de qualquer parcela importará no vencimento antecipado do saldo devedor.

Art. 218. Provado o pagamento integral, o Tribunal expedirá quitação do débito ou da multa ao responsável, desde que o processo não tenha sido remetido para cobrança judicial.

$\S 1^{\circ} \mathrm{O}$ pagamento integral do débito ou da multa não importa em modificação do julgamento quanto à irregularidade das contas.

$\S 2^{\circ}$ Caso já tenha sido encaminhada a documentação para cobrança executiva, a comunicação do pagamento da dívida será enviada ao órgão executor.

Art. 219. Expirado o prazo a que se refere a alínea a do inciso III do art. 214, sem manifestação do responsável, o Tribunal:

I - determinará o desconto integral ou parcelado da dívida nos vencimentos, subsídio, salário ou proventos do responsável, observados os limites previstos na legislação pertinente;

II - autorizará, alternativamente, a cobrança judicial da dívida, por intermédio do Ministério Público junto ao Tribunal;

III - providenciará a inclusão do nome do responsável no Cadastro Informativo de créditos não quitados do setor público federal - Cadin, na forma estabelecida em ato normativo.

Parágrafo único. Caso o ressarcimento deva ser feito a estado ou município, o Tribunal remeterlhes-á a documentação necessária à cobrança judicial da dívida.

Art. 220. Para os fins previstos no art. $1^{\circ}$, inciso I, alínea g e no art. $3^{\circ}$ da Lei Complementar $n^{\circ}$ 64, de 18 de maio de 1990, o Tribunal, com a devida antecedência ou quando solicitado, enviará ao Ministério Público Eleitoral, em tempo hábil, o nome dos responsáveis cujas contas houverem sido julgadas irregulares nos cinco anos imediatamente anteriores à época em que forem realizadas eleições no âmbito da União, dos estados, do Distrito Federal e dos municípios.

Parágrafo único. Não se aplica o disposto neste artigo aos processos em que houver recurso com efeito suspensivo cuja admissibilidade tenha sido reconhecida pelo relator.

\section{CAPÍTULO II APRECIAÇÃO DAS CONTAS DO PRESIDENTE DA REPÚBLICA}

Art. 221. O Tribunal de Contas da União apreciará as Contas prestadas anualmente pelo Presidente da República, mediante parecer prévio a ser elaborado em sessenta dias a contar da data de seu recebimento.

$\S 1^{\circ}$ (Revogado)

Parágrafo único. As contas prestadas pelo Presidente da República consistirão nos balanços gerais da União e no relatório do órgão central do sistema de controle interno do Poder Executivo sobre a execução dos orçamentos de que trata o $\S 5^{\circ}$ do art. 165 da Constituição Federal.

$\S 3^{\circ}$ (Revogado)

$\S 4^{\circ}$ (Revogado) 
Art. 222. O Tribunal estabelecerá em ato normativo específico a forma de apresentação do relatório que acompanha as contas prestadas pelo Presidente da República, elaborado pelo órgão central do sistema de controle interno do Poder Executivo.

Art. 223. O relatório e o projeto dos parecer prévio sobre as Contas do Presidente da República serão apresentados ao Plenário pelo relator dentro do prazo de cinquenta dias a contar do recebimento das contas pelo Tribunal.

Parágrafo único. Esse prazo poderá ser ampliado, por deliberação do Plenário, mediante solicitação justificada do relator, observado o disposto no art. 226.

Art. 224. O relator, além dos elementos contidos nas contas prestadas, poderá solicitar esclarecimentos adicionais e efetuar, por intermédio de unidade própria, fiscalizações que entenda necessárias à elaboração do seu relatório.

Art. 225. Os trabalhos voltados à instrução das contas a que se refere este capítulo observarão as diretrizes propostas pelo relator e aprovadas pelo Plenário, bem como o plano de controle externo.

$\S 1^{\circ}$ (Revogado)

$\S 2^{\circ}$ (Revogado)

Art. 226. A apreciação das contas tratadas neste capítulo pelo Tribunal far-se-á em sessão extraordinária a ser realizada com antecedência mínima de setenta e duas horas do término do prazo para a remessa do relatório e pareceres ao Congresso Nacional.

Art. 227. O relator, até cinco dias antes da data da sessão a que se refere o artigo anterior, fará distribuir cópia do relatório e do parecer prévio ao Presidente, ministros, ministros-substitutos e ao representante do Ministério Público junto ao Tribunal.

Art. 228. O parecer prévio a que se refere o caput do art. 221 será conclusivo no sentido de exprimir se as contas prestadas pelo Presidente da República representam adequadamente as posições financeira, orçamentária, contábil e patrimonial, em 31 de dezembro, bem como sobre a observância dos princípios constitucionais e legais que regem a administração pública federal. $\S 1^{\circ} \mathrm{O}$ parecer prévio conterá registros sobre a observância às normas constitucionais, legais e regulamentares na execução dos orçamentos da União e nas demais operações realizadas com recursos públicos federais, em especial quanto ao que estabelece a lei orçamentária anual.

$\S 2^{\circ} \mathrm{O}$ relatório, que acompanhará o parecer prévio, conterá informações sobre:

I - o cumprimento dos programas previstos na lei orçamentária anual quanto à legitimidade, eficiência e economicidade, bem como o atingimento de metas e a consonância destes com o plano plurianual e com a lei de diretrizes orçamentárias;

II - o reflexo da administração financeira e orçamentária federal no desenvolvimento econômico e social do País.

III - o cumprimento dos limites e parâmetros estabelecidos pela Lei Complementar $\mathrm{n}^{\mathrm{o}} 101$, de 4/5/2000 - Lei de Responsabilidade Fiscal.

Art. 229. O Tribunal restituirá ao Congresso Nacional as Contas do Presidente da República acompanhadas do parecer prévio aprovado pelo Plenário, do relatório apresentado pelo relator e das declarações de voto emitidas pelos demais ministros e ministros-substitutos convocados. Parágrafo único. Os elementos a que se refere o caput serão publicados em separata da Revista do Tribunal de Contas da União, para ampla divulgação.

\author{
CAPÍTULO III \\ FISCALIZAÇÃO \\ SEÇÃO I \\ INICIATIVA DA FISCALIZAÇÃO \\ SUBSEÇÃO I
}




\section{FISCALIZAÇÃO EXERCIDA POR INICIATIVA PRÓPRIA}

Art. 230. O Tribunal, no exercício de suas atribuições, poderá realizar, por iniciativa própria, fiscalizações nos órgãos e entidades sob sua jurisdição, com vistas a verificar a legalidade, a economicidade, a legitimidade, a eficiência, a eficácia e a efetividade de atos, contratos e fatos administrativos.

\section{SUBSEÇÃO II \\ FISCALIZAÇÃO EXERCIDA POR INICIATIVA DO CONGRESSO NACIONAL}

Art. 231. O Tribunal apreciará, em caráter de urgência, os pedidos de informação e as solicitações previstas nos incisos II a $\mathrm{V}$ do art. $1^{\mathrm{o}}$, que lhe forem endereçados pelo Congresso Nacional, por qualquer de suas casas ou pelas respectivas comissões.

Art. 232. Nos termos dos incisos IV e VII do art. 71 e $\S 1^{\circ}$ do art. 72 da Constituição Federal, são competentes para solicitar ao Tribunal a prestação de informações e a realização de auditorias e inspeções:

I - Presidente do Senado Federal;

II - Presidente da Câmara dos Deputados; e

III - presidentes de comissões do Congresso Nacional, do Senado Federal ou da Câmara dos Deputados, quando por aquelas aprovadas.

$\S 1^{\circ} \mathrm{O}$ Tribunal regulamentará as formas de atendimento às solicitações de que trata este artigo, bem como aos pedidos de cópia e de vista de processo oriundos do Congresso Nacional, além de definir os legitimados a efetuar esses pedidos.

$\S 2^{\circ} \mathrm{O}$ Plenário ou o relator não conhecerá de solicitações encaminhadas ao Tribunal por quem não seja legitimado.

Art. 233. Se a solicitação implicar a realização de auditoria, o relator submeterá à deliberação do Plenário sua inclusão no plano de fiscalização do Tribunal.

\section{SUBSEÇÃO III \\ DENƯNCIA}

Art. 234. Qualquer cidadão, partido político, associação ou sindicato é parte legítima para denunciar irregularidades ou ilegalidades perante o Tribunal de Contas da União.

$\S 1^{\circ}$ Em caso de urgência, a denúncia poderá ser encaminhada ao Tribunal por telegrama, facsímile ou outro meio eletrônico, sempre com confirmação de recebimento e posterior remessa do original em dez dias, contados a partir da mencionada confirmação.

$\S 2^{\circ}$ A denúncia que preencha os requisitos de admissibilidade será apurada em caráter sigiloso, até que se comprove a sua procedência, e somente poderá ser arquivada após efetuadas as diligências pertinentes, mediante despacho fundamentado do relator.

$\S 3^{\circ}$ Reunidas as provas que indiquem a existência de irregularidade ou ilegalidade, serão públicos os demais atos do processo, observado o disposto no art. 236, assegurando-se aos acusados oportunidade de ampla defesa.

$\S 4^{\circ}$ Os processos concernentes a denúncia observarão, no que couber, os procedimentos prescritos nos arts. 250 a 252.

Art. 235. A denúncia sobre matéria de competência do Tribunal deverá referir-se a administrador ou responsável sujeito à sua jurisdição, ser redigida em linguagem clara e objetiva, conter o nome legível do denunciante, sua qualificação e endereço, e estar acompanhada de indício concernente à irregularidade ou ilegalidade denunciada. 
Parágrafo único. O relator ou o Tribunal não conhecerá de denúncia que não observe os requisitos e formalidades prescritos no caput, devendo o respectivo processo ser arquivado após comunicação ao denunciante.

Art. 236. No resguardo dos direitos e garantias individuais, o Tribunal dará tratamento sigiloso às denúncias formuladas, até decisão definitiva sobre a matéria.

$\S 1^{\circ}$ Salvo expressa manifestação em contrário, o processo de denúncia tornar-se-á público após a decisão definitiva sobre a matéria.

$\S 2^{\circ} \mathrm{O}$ denunciante não se sujeitará a nenhuma sanção administrativa, cível ou penal em decorrência da denúncia, salvo em caso de comprovada má-fé.

\section{SUBSEÇÃO IV \\ REPRESENTAÇÃO}

Art. 237. Têm legitimidade para representar ao Tribunal de Contas da União:

I - o Ministério Público da União, nos termos do art. $6^{\circ}$, inciso XVIII, alínea c, da Lei Complementar $n^{\circ} 75 / 93$;

II - os órgãos de controle interno, em cumprimento ao $\S 1^{\circ}$ do art. 74 da Constituição Federal; III - os senadores da República, deputados federais, estaduais e distritais, juízes, servidores públicos e outras autoridades que comuniquem a ocorrência de irregularidades de que tenham conhecimento em virtude do cargo que ocupem;

IV - os tribunais de contas dos estados, do Distrito Federal e dos municípios, as câmaras municipais e os ministérios públicos estaduais;

$\mathrm{V}$ - as equipes de inspeção ou de auditoria, nos termos do art. 246;

VI - as unidades técnicas do Tribunal; e

VII - outros órgãos, entidades ou pessoas que detenham essa prerrogativa por força de lei específica.

Parágrafo único. Aplicam-se às representações os dispositivos constantes do $\S 1^{\circ}$ e da segunda parte do $\S 2^{\circ}$ do art. 234, do caput e do parágrafo único do art. 235 e dos arts. 250 a 252.

\section{SEÇÃO II \\ INSTRUMENTOS DA FISCALIZAÇÃO \\ SUBSEÇÃO I \\ LEVANTAMENTOS}

Art. 238. Levantamento é o instrumento de fiscalização utilizado pelo Tribunal para:

I - conhecer a organização e o funcionamento dos órgãos e entidades da administração direta, indireta e fundacional dos Poderes da União, incluindo fundos e demais instituições que lhe sejam jurisdicionadas, assim como dos sistemas, programas, projetos e atividades governamentais no que se refere aos aspectos contábeis, financeiros, orçamentários, operacionais e patrimoniais;

II - identificar objetos e instrumentos de fiscalização; e

III - avaliar a viabilidade da realização de fiscalizações.

\section{SUBSEÇÃO II AUDITORIAS}

Art. 239. Auditoria é o instrumento de fiscalização utilizado pelo Tribunal para: 
I - examinar a legalidade e a legitimidade dos atos de gestão dos responsáveis sujeitos a sua jurisdição, quanto ao aspecto contábil, financeiro, orçamentário e patrimonial;

II - avaliar o desempenho dos órgãos e entidades jurisdicionados, assim como dos sistemas, programas, projetos e atividades governamentais, quanto aos aspectos de economicidade, eficiência e eficácia dos atos praticados;

III - subsidiar a apreciação dos atos sujeitos a registro.

\section{SUBSEÇÃO III \\ INSPEÇÕES}

Art. 240. Inspeção é o instrumento de fiscalização utilizado pelo Tribunal para suprir omissões e lacunas de informações, esclarecer dúvidas ou apurar denúncias ou representações quanto à legalidade, à legitimidade e à economicidade de fatos da administração e de atos administrativos praticados por qualquer responsável sujeito à sua jurisdição.

\section{SUBSEÇÃO IV ACOMPANHAMENTOS}

Art. 241. Acompanhamento é o instrumento de fiscalização utilizado pelo Tribunal para: I - examinar, ao longo de um período predeterminado, a legalidade e a legitimidade dos atos de gestão dos responsáveis sujeitos a sua jurisdição, quanto ao aspecto contábil, financeiro, orçamentário e patrimonial; e

II - avaliar, ao longo de um período predeterminado, o desempenho dos órgãos e entidades jurisdicionadas, assim como dos sistemas, programas, projetos e atividades governamentais, quanto aos aspectos de economicidade, eficiência e eficácia dos atos praticados.

Art. 242. As atividades dos órgãos e entidades jurisdicionadas ao Tribunal serão acompanhadas de forma seletiva e concomitante, mediante informações obtidas:

I - pela publicação nos órgãos oficiais e mediante consulta a sistemas informatizados adotados pela administração pública federal:

a) da lei relativa ao plano plurianual, da lei de diretrizes orçamentárias, da lei orçamentária anual e da abertura de créditos adicionais;

b) dos editais de licitação, dos extratos de contratos e de convênios, acordos, ajustes, termos de parceria ou outros instrumentos congêneres, bem como dos atos referidos no art. 259;

II - por meio de expedientes e documentos solicitados pelo Tribunal ou colocados à sua disposição;

III - por meio de visitas técnicas ou participações em eventos promovidos por órgãos e entidades da administração pública.

IV - pelo acesso a informações publicadas em sítio eletrônico do órgão ou entidade.

Parágrafo único. As informações obtidas pelos procedimentos previstos neste artigo independem da existência de processo autuado, podendo ser objeto de delegação de competência.

\section{SUBSEÇÃO V MONITORAMENTOS}

Art. 243. Monitoramento é o instrumento de fiscalização utilizado pelo Tribunal para verificar o cumprimento de suas deliberações e os resultados delas advindos. 


\section{SEÇÃO III \\ PLANO DE FISCALIZAÇÃO}

Art. 244. As auditorias, acompanhamentos e monitoramentos obedecerão a plano de fiscalização elaborado pela Presidência, em consulta com os relatores das listas de unidades jurisdicionadas, e aprovado pelo Plenário em sessão de caráter reservado.

$\S 1^{\circ}$ A periodicidade do plano de fiscalização, bem como os critérios e procedimentos para sua elaboração, serão estabelecidos em ato próprio do Tribunal.

$\S 2^{\circ}$ Os levantamentos e inspeções serão realizados por determinação do Plenário, da câmara, do relator ou, na hipótese do art. 28, inciso XVI, do Presidente, independentemente de programação, observada a disponibilidade dos recursos humanos e materiais necessários.

\section{SEÇÃO IV \\ EXECUÇÃO DAS FISCALIZAÇÕES}

Art. 245. Ao servidor que exerce função específica de controle externo, quando credenciado pelo Presidente do Tribunal, ou por delegação deste, pelos dirigentes das unidades técnicas da Secretaria, para desempenhar funções de fiscalização, são asseguradas as seguintes prerrogativas:

I - livre ingresso em órgãos e entidades sujeitos à jurisdição do Tribunal;

II - acesso a todos os processos, documentos e informações necessários à realização de seu trabalho, mesmo a sistemas eletrônicos de processamento de dados, que não poderão ser sonegados, sob qualquer pretexto;

III - competência para requerer, por escrito, aos responsáveis pelos órgãos e entidades, os documentos e informações desejados, fixando prazo razoável para atendimento.

$\S 1^{\circ}$ No caso de obstrução ao livre exercício de auditorias e inspeções, ou de sonegação de processo, documento ou informação, o Tribunal ou o relator assinará prazo improrrogável de até quinze dias para apresentação de documentos, informações e esclarecimentos julgados necessários, fazendo-se a comunicação do fato ao ministro de Estado supervisor da área ou à autoridade de nível hierárquico equivalente, para as medidas cabíveis.

$\S 2^{\circ}$ Vencido o prazo e não cumprida a exigência, o Tribunal aplicará a sanção prescrita no inciso V ou VI do art. 268, observado o disposto no $\S 3^{\circ}$ do mesmo artigo, e representará ao Presidente do Congresso Nacional sobre o fato, para as medidas cabíveis.

$\S 3^{\circ}$ Sem prejuízo da sanção referida no parágrafo anterior, poderá o Plenário adotar a medida prevista no art. 273.

Art. 246. No curso de fiscalização, se verificado procedimento de que possa resultar dano ao erário ou irregularidade grave, a equipe representará, desde logo, com suporte em elementos concretos e convincentes, ao dirigente da unidade técnica, o qual submeterá a matéria ao respectivo relator, com parecer conclusivo.

$\S 1^{\circ} \mathrm{O}$ relator, considerando a urgência requerida, fixará prazo de até cinco dias úteis para que o responsável se pronuncie sobre os fatos apontados.

$\S 2^{\circ}$ A fixação de prazo para pronunciamento não impede que o Tribunal ou o relator adote, desde logo, medida cautelar, de acordo com o disposto no art. 276, independentemente do recebimento ou da análise prévia das justificativas da parte.

Art. 247. As modalidades e procedimentos a serem observados na realização de fiscalizações serão definidos em ato normativo.

Art. 248. O Tribunal comunicará às autoridades competentes o resultado das fiscalizações que realizar, para as medidas saneadoras das impropriedades e faltas identificadas. 


\section{SEÇÃO V \\ OBJETO DA FISCALIZAÇÃO \\ SUBSEÇÃO I \\ DISPOSIÇÕES GERAIS SOBRE A FISCÁLIZAÇÃO DE ATOS E CONTRATOS}

Art. 249. Para assegurar a eficácia do controle e para instruir o julgamento das contas, o Tribunal efetuará a fiscalização dos atos de que resulte receita ou despesa, praticados pelos responsáveis sujeitos à sua jurisdição, competindo-lhe, para tanto, em especial:

I - realizar fiscalizações, na forma estabelecida nos arts. 238 a 243;

II - fiscalizar as contas nacionais das empresas supranacionais a que se refere o inciso XVIII do art. $1^{\circ}$, na forma estabelecida em ato normativo;

III - fiscalizar, na forma estabelecida no art. 254, a aplicação de quaisquer recursos repassados pela União mediante convênio, acordo, ajuste ou outros instrumentos congêneres, a estado, ao Distrito Federal, a município, e a qualquer outra pessoa, física ou jurídica, pública ou privada; Art. 250. Ao apreciar processo relativo à fiscalização de atos e contratos, o relator ou o Tribunal: I - determinará o arquivamento do processo, ou o seu apensamento às contas correspondentes, se útil à apreciação destas, quando não apurada transgressão a norma legal ou regulamentar de natureza contábil, financeira, orçamentária, operacional ou patrimonial;

II - determinará a adoção de providências corretivas por parte do responsável ou de quem lhe haja sucedido quando verificadas tão somente falhas de natureza formal ou outras impropriedades que não ensejem a aplicação de multa aos responsáveis ou que não configurem indícios de débito e o arquivamento ou apensamento do processo às respectivas contas, sem prejuízo do monitoramento do cumprimento das determinações;

III - recomendará a adoção de providências quando verificadas oportunidades de melhoria de desempenho, encaminhando os autos à unidade técnica competente, para fins de monitoramento do cumprimento das determinações;

IV - determinará a audiência do responsável para, no prazo de quinze dias, apresentar razões de justificativa, quando verificada a ocorrência de irregularidades decorrentes de ato ilegal, ilegítimo ou antieconômico, bem como infração a norma legal ou regulamentar de natureza contábil, financeira, orçamentária ou patrimonial.

V - determinará a oitiva da entidade fiscalizada e do terceiro interessado para, no prazo de quinze dias, manifestarem-se sobre fatos que possam resultar em decisão do Tribunal no sentido de desconstituir ato ou processo administrativo ou alterar contrato em seu desfavor.

$\S 1^{\circ}$ Acolhidas as razões de justificativa, o Tribunal declarará esse fato mediante acórdão e, conforme o caso, adotará uma das providências previstas no inciso I.

$\S 2^{\circ}$ Não elidido o fundamento da impugnação, o Tribunal aplicará ao responsável, no próprio processo de fiscalização, ressalvado o disposto no art. 206, a multa prevista no inciso II ou III do art. 268

e determinará o apensamento do processo às contas correspondentes.

$\S 3^{\circ} \mathrm{Na}$ oportunidade do exame das contas, será verificada a conveniência da renovação da determinação das providências de que trata o inciso II do caput, com vistas a aplicar oportunamente, se for o caso, o disposto no $\S 1^{\circ}$ do art. 209.

$\S 4^{\circ} \mathrm{O}$ apensamento, às respectivas contas, de processos referentes a atos de admissão de pessoal e concessão de aposentadoria, pensão e reforma será regulamentado em ato normativo.

$\S 5^{\circ} \mathrm{A}$ aplicação de multa em processo de fiscalização não implicará prejulgamento das contas ordinárias da unidade jurisdicionada, devendo o fato ser considerado no contexto dos demais atos de gestão do período envolvido. 
$\S 6^{\circ}$ Caso as matérias objeto da oitiva de que trata o inciso $\mathrm{V}$ demandem urgente decisão de mérito, a unidade técnica responsável pela fiscalização dará a elas prioridade na instrução processual, deixando para propor as medidas constantes dos incisos II, III e IV em momento posterior à deliberação do Tribunal sobre aquelas questões.

$\S 7^{\circ}$ Observar-se-ão em relação à oitiva prevista no inciso $\mathrm{V}$ as normas aplicáveis à audiência, no que couber.

Art. 251. Verificada a ilegalidade de ato ou contrato em execução, o Tribunal assinará prazo de até quinze dias para que o responsável adote as providências necessárias ao exato cumprimento da lei, com indicação expressa dos dispositivos a serem observados, sem prejuízo do disposto no inciso IV do caput e nos $\S \S 1^{\circ}$ e $2^{\circ}$ do artigo anterior.

$\S 1^{\circ}$ No caso de ato administrativo, o Tribunal, se não atendido:

I - sustará a execução do ato impugnado;

II - comunicará a decisão à Câmara dos Deputados e ao Senado Federal;

III - aplicará ao responsável, no próprio processo de fiscalização, a multa prevista no inciso VII do art. 268.

$\S 2^{\circ}$ No caso de contrato, o Tribunal, se não atendido, adotará a providência prevista no inciso

III do parágrafo anterior e comunicará o fato ao Congresso Nacional, a quem compete adotar o ato de sustação e solicitar, de imediato, ao Poder Executivo, as medidas cabíveis.

$\S 3^{\circ}$ Se o Congresso Nacional ou o Poder Executivo, no prazo de noventa dias, não efetivar as medidas previstas no parágrafo anterior, o Tribunal decidirá a respeito da sustação do contrato. $\S 4^{\circ}$ Verificada a hipótese do parágrafo anterior, e se decidir sustar o contrato, o Tribunal:

I - determinará ao responsável que, no prazo de quinze dias, adote as medidas necessárias ao cumprimento da decisão;

II - comunicará o decidido ao Congresso Nacional e à autoridade de nível ministerial competente.

Art. 252. Se configurada a ocorrência de desfalque, desvio de bens ou outra irregularidade de que resulte dano ao erário, o Tribunal ordenará, desde logo, a conversão do processo em tomada de contas especial, salvo na hipótese prevista no art. 213.

Parágrafo único. Caso a tomada de contas especial envolva responsável por contas ordinárias, deverá ser observado o disposto no art. 206.

\section{SUBSEÇÃO II \\ FISCALIZAÇÃO DAS TRANSFERÊNCIAS CONSTITUCIONAIS E LEGAIS}

Art. 253. O Tribunal fiscalizará, na forma estabelecida em ato normativo:

I - a entrega das parcelas devidas aos estados, ao Distrito Federal e aos municípios à conta dos recursos dos fundos de participação a que alude o parágrafo único do art. 161 da Constituição Federal;

II - a aplicação dos recursos dos fundos constitucionais do Norte, Nordeste e Centro-Oeste administrados por instituições federais;

III - a aplicação dos recursos transferidos ao Distrito Federal com base no inciso XIV do art.

21 da Constituição Federal;

IV - o cálculo, a entrega e a aplicação, conforme o caso, de quaisquer recursos repassados pela União por determinação legal a estado, ao Distrito Federal ou a município, consoante dispuser a legislação específica.

\section{SUBSEÇÃO III}




\section{FISCALIZAÇÃO DE CONVÊNIOS, ACORDOS, AJUSTES E OUTROS INSTRUMENTOS CONGÊNERES}

Art. 254. A fiscalização da aplicação de quaisquer recursos repassados pela União, autarquias, fundações instituídas e mantidas pelo poder público e demais órgãos e entidades da administração pública federal mediante convênio, acordo, ajuste ou outros instrumentos congêneres, a estado, ao Distrito Federal, a município, e a qualquer outra pessoa, física ou jurídica, pública ou privada, será feita pelo Tribunal por meio de levantamentos, auditorias, inspeções, acompanhamentos ou monitoramentos, bem como por ocasião do exame dos processos de tomadas ou prestações de contas da unidade ou entidade transferidora dos recursos.

$\S 1^{\circ}$ Para o cumprimento do disposto neste artigo deverão ser verificados, entre outros aspectos, o atingimento dos objetivos acordados, a correção da aplicação dos recursos, a observância às normas legais e regulamentares pertinentes e às cláusulas pactuadas.

$\S 2^{\circ}$ Ficará sujeito à multa prevista no inciso II ou III do art. 268 a autoridade administrativa que transferir, mediante convênio, acordo, ajuste ou outros instrumentos congêneres, recursos federais a gestores omissos na prestação de contas de recursos anteriormente recebidos ou que tenham dado causa a perda, extravio ou outra irregularidade que resulte dano ao erário, ainda não ressarcido.

$\S 3^{\circ}$ A autoridade administrativa competente deverá adotar imediatas providências com vistas à instauração de tomada de contas especial no caso de omissão na prestação de contas ou quando constatar irregularidade na aplicação dos recursos federais transferidos, sob pena de responsabilidade solidária, na forma prescrita em ato normativo.

\section{SUBSEÇÃO IV \\ FISCALIZAÇÃO DA APLICAÇÃO DE SUBVENÇÕES, AUXÍLIOS E CONTRIBUIÇÕES}

Art. 255. A fiscalização pelo Tribunal da aplicação de recursos transferidos sob as modalidades de subvenção, auxílio e contribuição compreenderá as fases de concessão, utilização e prestação de contas e será realizada, no que couber, na forma estabelecida no art. 254.

\section{SUBSEÇÃO V \\ FISCALIZAÇÃO DA ARRECADAÇÃO DA RECEITA}

Art. 256. A fiscalização da arrecadação da receita a cargo dos órgãos e entidades da administração direta, indireta e fundacional dos Poderes da União, bem como dos fundos e demais instituições sob jurisdição do Tribunal, far-se-á em todas as etapas da receita e processar-se-á mediante levantamentos, auditorias, inspeções, acompanhamentos ou monitoramentos, incluindo a análise de demonstrativos próprios, com a identificação dos respectivos responsáveis, na forma estabelecida em ato normativo.

\section{SUBSEÇÃO VI \\ FISCALIZAÇÃO DA RENÚNCIA DE RECEITAS}

Art. 257. A fiscalização pelo Tribunal da renúncia de receitas será feita, preferentemente, mediante auditorias, inspeções ou acompanhamentos nos órgãos supervisores, bancos operadores e fundos que tenham atribuição administrativa de conceder, gerenciar ou utilizar os recursos decorrentes das aludidas renúncias, sem prejuízo do julgamento das tomadas e 
prestações de contas apresentadas pelos referidos órgãos, entidades e fundos, quando couber, na forma estabelecida em ato normativo.

Parágrafo único. A fiscalização terá como objetivos, entre outros, verificar a legalidade, legitimidade, eficiência, eficácia e economicidade das ações dos órgãos e entidades mencionados no caput, bem como o real benefício socioeconômico dessas renúncias.

\section{SUBSEÇÃO VII \\ OUTRAS FISCALIZAÇÕES}

Art. 258. O Tribunal realizará, ainda, na forma definida em atos normativos específicos:

I - a fiscalização, no âmbito de suas atribuições, do cumprimento, por parte dos órgãos e entidades da União, das normas da Lei Complementar $n^{\circ} 101$, de 4 de maio de 2000 - Lei de Responsabilidade Fiscal;

II - o acompanhamento, a fiscalização e a avaliação dos processos de desestatização realizados pela administração pública federal, compreendendo as privatizações de empresas, incluindo instituições financeiras, e as concessões, permissões e autorizações de serviço público, previstas no art. 175 da Constituição Federal e nas normas legais pertinentes, conforme disposto em ato normativo;

III - a fiscalização das declarações de bens e rendas apresentadas pelas autoridades e servidores públicos, nos termos da legislação em vigor;

IV - a fiscalização da aplicação dos recursos repassados ao Comitê Olímpico Brasileiro e ao Comitê Paraolímpico Brasileiro por força da legislação vigente;

$\mathrm{V}$ - outras fiscalizações determinadas em lei.

\section{CAPÍTULO IV \\ APRECIAÇÃO DE ATOS SUJEITOS A REGISTRO}

Art. 259. O Tribunal apreciará, para fins de registro, mediante procedimentos de físcalização ou processo específico, na forma estabelecida em normativos específicos, os atos de:

I - admissão de pessoal, a qualquer título, na administração direta e indireta, incluídas as fundações instituídas e mantidas pelo poder público federal, excetuadas as nomeações para cargo de provimento em comissão;

II - concessão de aposentadorias, reformas e pensões a servidores públicos federais civis e militares ou a seus beneficiários, ressalvadas as melhorias posteriores que não alterem o fundamento legal do ato concessório inicial.

Art. 260. Para o exercício da competência atribuída ao Tribunal, nos termos do inciso III do art. 71 da Constituição Federal, a autoridade administrativa responsável por ato de admissão de pessoal ou de concessão de aposentadoria, reforma ou pensão, a que se refere o artigo anterior, submeterá os dados e informações necessários ao respectivo órgão de controle interno, que deverá emitir parecer sobre a legalidade dos referidos atos e torná-los disponíveis à apreciação do Tribunal, na forma estabelecida em ato normativo.

$\S 1^{\circ} \mathrm{O}$ Tribunal determinará o registro dos atos que considerar legais e recusará o registro dos atos considerados ilegais. 
$\S 2^{\circ} \mathrm{O}$ acórdão que considerar legal o ato e determinar o seu registro não faz coisa julgada administrativa e poderá ser revisto de ofício pelo Tribunal, com a oitiva do Ministério Público e do beneficiário do ato, dentro do prazo de cinco anos da apreciação, se verificado que o ato viola a ordem jurídica, ou a qualquer tempo, no caso de comprovada má-fé.

$\S 3^{\circ}$ Identificada irregularidade em ato de concessão já cadastrado nos sistemas

informatizados do TCU, poderá o Tribunal proceder ao exame do respectivo ato, dispensando a manifestação do órgão de controle interno respectivo.

$\S 4^{\circ}$ Os atos que, a despeito de apresentarem algum tipo de inconsistência em sua versão submetida ao exame do Tribunal, não estiverem dando ensejo, no momento de sua apreciação, apagamentos irregulares, serão considerados legais, para fins de registro, devendo ser consignada no julgamento a ressalva em relação à falha que deixou de existir.

$\S 5^{\circ} \mathrm{O}$ Tribunal poderá considerar prejudicado, por perda de objeto, o exame dos atos de admissão e concessão cujos efeitos financeiros tenham se exaurido antes de sua apreciação. § $6^{\circ}$ Será considerado prejudicado, por inépcia, o ato de admissão ou concessão que apresentar inconsistências nas informações prestadas pelo órgão de pessoal que impossibilitem sua análise, devendo ser determinado o encaminhamento de novo ato, livre de falhas.

Art. 261. Quando o Tribunal considerar ilegal ato de admissão de pessoal, o órgão de origem deverá, observada a legislação pertinente, adotar as medidas regularizadoras cabíveis, fazendo cessar todo e qualquer pagamento decorrente do ato impugnado.

$\S 1^{\circ} \mathrm{O}$ responsável que injustificadamente deixar de adotar as medidas de que trata o caput, no prazo de quinze dias, contados da ciência da decisão deste Tribunal, ficará sujeito a multa e ao ressarcimento das quantias pagas após essa data.

$\S 2^{\circ}$ Se houver indício de procedimento culposo ou doloso na admissão de pessoal, o Tribunal determinará a instauração ou conversão do processo em tomada de contas especial, para apurar responsabilidades e promover o ressarcimento das despesas irregularmente efetuadas. Art. 262. Quando o ato de concessão de aposentadoria, reforma ou pensão for considerado

ilegal, o órgão de origem fará cessar o pagamento dos proventos ou benefícios no prazo de quinze dias, contados da ciência da decisão do Tribunal, sob pena de responsabilidade solidária da autoridade administrativa omissa.

$\S 1^{\circ}$ Caso não seja suspenso o pagamento, ou havendo indício de procedimento culposo ou doloso na concessão de benefício sem fundamento legal, o Tribunal determinará a instauração ou a conversão do processo em tomada de contas especial, para apurar responsabilidades e promover o ressarcimento das despesas irregularmente efetuadas.

$\S 2^{\circ}$ Recusado o registro do ato, por ser considerado ilegal, a autoridade administrativa responsável poderá emitir novo ato, se for o caso, escoimado das irregularidades verificadas. $\S 3^{\circ}$ Verificada a omissão total ou parcial de vantagens a que faz jus o interessado, o Tribunal poderá considerar o ato legal, independentemente das comunicações que entender oportunas para cada caso.

Art. 263. O relator ou o Tribunal não conhecerá de requerimento que lhe seja diretamente dirigido por interessado na obtenção de quaisquer benefícios ou vantagens de caráter pessoal, devendo a solicitação ser arquivada após comunicação ao requerente.

\section{CAPÍTULO V \\ RESPOSTA A CONSULTA}

Art. 264. O Plenário decidirá sobre consultas quanto a dúvida suscitada na aplicação de dispositivos legais e regulamentares concernentes à matéria de sua competência, que lhe forem formuladas pelas seguintes autoridades: 
I - presidentes da República, do Senado Federal, da Câmara dos Deputados e do Supremo Tribunal Federal;

II - Procurador-Geral da República;

III - Advogado-Geral da União;

IV - presidente de comissão do Congresso Nacional ou de suas casas;

$\mathrm{V}$ - presidentes de tribunais superiores;

VI - ministros de Estado ou autoridades do Poder Executivo federal de nível hierárquico equivalente;

VII - comandantes das Forças Armadas.

$\S 1^{\circ}$ As consultas devem conter a indicação precisa do seu objeto, ser formuladas articuladamente e instruídas, sempre que possível, com parecer do órgão de assistência técnica ou jurídica da autoridade consulente.

$\S 2^{\circ}$ Cumulativamente com os requisitos do parágrafo anterior, as autoridades referidas nos incisos IV, V, VI e VII deverão demonstrar a pertinência temática da consulta às respectivas áreas de atribuição das instituições que representam.

$\S 3^{\circ}$ A resposta à consulta a que se refere este artigo tem caráter normativo e constitui prejulgamento da tese, mas não do fato ou caso concreto.

$\S 4^{\circ} \mathrm{A}$ decisão sobre processo de consulta somente será tomada se presentes na sessão pelo menos sete ministros, incluindo ministros-substitutos convocados, além do Presidente.

Art. 265. O relator ou o Tribunal não conhecerá de consulta que não atenda aos requisitos do artigo anterior ou verse apenas sobre caso concreto, devendo o processo ser arquivado após comunicação ao consulente.

\section{TÍTULO VII \\ SANÇÕES \\ CAPÍTULO I \\ DISPOSIÇÕES GERAIS}

Art. 266. O Tribunal de Contas da União poderá aplicar aos administradores ou responsáveis que lhe são jurisdicionados as sanções prescritas na Lei $n^{\circ}$ 8.443, de 1992, na forma estabelecida neste título.

Parágrafo único. Às mesmas sanções previstas neste título ficarão sujeitos, por responsabilidade solidária, na forma prevista no $\S 1^{\circ}$ do art. 74 da Constituição Federal, os responsáveis pelo controle interno que, comprovadamente, tomarem conhecimento de irregularidade ou ilegalidade e delas deixarem de dar imediata ciência ao Tribunal.

\section{CAPÍTULO II MULTAS}

Art. 267. Quando o responsável for julgado em débito, poderá ainda o Tribunal aplicar-lhe multa de até cem por cento do valor atualizado do dano causado ao erário, conforme estabelecido no art. 57 da Lei $n^{\circ} 8.443$, de 1992.

Art. 268. O Tribunal poderá aplicar multa, nos termos do caput do art. 58 da Lei $\mathrm{n}^{\circ} 8.443$, de 1992, atualizada na forma prescrita no $\S 1^{\circ}$ deste artigo, aos responsáveis por contas e atos adiante indicados, observada a seguinte gradação:

I - contas julgadas irregulares, não havendo débito, mas comprovada qualquer das ocorrências previstas nos incisos I, II e III do caput do art. 209, no valor compreendido entre cinco e cem por cento do montante definido no caput deste artigo; 
II - ato praticado com grave infração a norma legal ou regulamentar de natureza contábil, financeira, orçamentária, operacional ou patrimonial, no valor compreendido entre cinco e cem por cento do montante a que se refere o caput;

III - ato de gestão ilegítimo ou antieconômico de que resulte injustificado dano ao erário, no valor compreendido entre cinco e cem por cento do montante referido no caput;

IV - descumprimento, no prazo fixado, sem causa justificada, à diligência determinada pelo relator, no valor compreendido entre cinco e cinquenta por cento do montante a que se refere o caput;

V - obstrução ao livre exercício das auditorias e inspeções determinadas, no valor compreendido entre cinco e oitenta por cento do montante a que se refere o caput;

VI - sonegação de processo, documento ou informação, em auditoria ou inspeção, no valor compreendido entre cinco e oitenta por cento do montante a que se refere o caput;

VII - descumprimento de decisão do Tribunal, salvo motivo justificado, no valor compreendido entre cinco e cinquenta por cento do montante a que se refere o caput;

VIII - reincidência no descumprimento de decisão do Tribunal, no valor compreendido entre cinquenta e cem por cento do montante a que se refere o caput.

$\S 1^{\circ}$ A multa de que trata o caput será atualizada, periodicamente, mediante portaria da Presidência do Tribunal, com base na variação acumulada no período, pelo índice utilizado para atualização dos créditos tributários da União.

$\S 2^{\circ}$ Nos casos em que ficar demonstrada a inadequação da multa aplicada com fundamento nos incisos IV, V, VI ou VII, o Tribunal poderá revê-la, de ofício, diminuindo seu valor ou tornando-a sem efeito.

$\S 3^{\circ}$ A multa aplicada com fundamento nos incisos IV, V, VI, VII ou VIII prescinde de prévia audiência dos responsáveis, desde que a possibilidade de sua aplicação conste da comunicação do despacho ou da decisão descumprida ou do ofício de apresentação da equipe de fiscalização. Art. 269. O débito decorrente de multa aplicada pelo Tribunal, nos termos do artigo anterior, quando pago após o seu vencimento, será atualizado monetariamente desde a data do acórdão condenatório até a data do efetivo pagamento.

\section{CAPÍTULO III OUTRAS SANÇÕES}

Art. 270. Sem prejuízo das sanções previstas nos arts. 267 e 268 e das penalidades administrativas aplicáveis pelas autoridades competentes, por irregularidades constatadas pelo Tribunal, sempre que este, por maioria absoluta de seus membros, considerar grave a infração cometida, o responsável ficará inabilitado, por um período que variará de cinco a oito anos, para o exercício de cargo em comissão ou função de confiança no âmbito da administração pública federal, nos termos do art. 60 da Lei nº 8.443, de 1992.

$\S 1^{\circ} \mathrm{O}$ Tribunal deliberará primeiramente sobre a gravidade da infração.

$\S 2^{\circ}$ Se considerada grave a infração, por maioria absoluta de seus membros, o Tribunal decidirá sobre o período de inabilitação a que ficará sujeito o responsável.

$\S 3^{\circ}$ Aplicada a sanção referida no caput, o Tribunal comunicará a decisão ao responsável e à autoridade competente para cumprimento dessa medida.

Art. 271. Verificada a ocorrência de fraude comprovada a licitação, o Plenário declarará a inidoneidade do licitante fraudador para participar, por até cinco anos, de licitação na administração pública federal, nos termos do art. 46 da Lei no 8.443, de 1992.

Art. 272. O Tribunal manterá cadastro específico das sanções aplicadas com fundamento nos arts. 270 e 271, observadas as prescrições legais a esse respeito. 


\section{TÍTULO VIII \\ MEDIDAS CAUTELARES}

Art. 273. No início ou no curso de qualquer apuração, o Plenário, de ofício, por sugestão de unidade técnica ou de equipe de fiscalização ou a requerimento do Ministério Público, determinará, cautelarmente, nos termos do art. 44 da Lei $n^{\circ}$ 8.443, de 1992, o afastamento temporário do responsável, se existirem indícios suficientes de que, prosseguindo no exercício de suas funções, possa retardar ou dificultar a realização de auditoria ou inspeção, causar novos danos ao erário ou inviabilizar o seu ressarcimento.

Parágrafo único. Será solidariamente responsável, conforme o $\S 1^{\circ}$ do art. 44 da Lei $\mathrm{n}^{\circ} 8.443$, de 1992, a autoridade superior competente que, no prazo fixado pelo Plenário, deixar de atender à determinação prevista no caput.

Art. 274. Nas mesmas circunstâncias do artigo anterior, poderá o Plenário, sem prejuízo das medidas previstas nos arts. 270 e 275 , decretar, por prazo não superior a um ano, a indisponibilidade de bens do responsável, tantos quantos considerados bastantes para garantir o ressarcimento dos danos em apuração, nos termos do $\S 2^{\circ}$ do art. 44 da Lei nº 8.443, de 1992. Art. 275. O Plenário poderá solicitar, por intermédio do Ministério Público junto ao Tribunal, na forma do inciso $\mathrm{V}$ do art. 62, à Advocacia-Geral da União ou, conforme o caso, aos dirigentes das entidades que lhe sejam jurisdicionadas, as medidas necessárias ao arresto dos bens dos responsáveis julgados em débito, devendo ser ouvido quanto à liberação dos bens arrestados e sua restituição, nos termos do art. 61 da Lei nº 8.443, de 1992.

Art. 276. O Plenário, o relator, ou, na hipótese do art. 28, inciso XVI, o Presidente, em caso de urgência, de fundado receio de grave lesão ao erário, ao interesse público, ou de risco de ineficácia da decisão de mérito, poderá, de ofício ou mediante provocação, adotar medida cautelar, com ou sem a prévia oitiva da parte, determinando, entre outras providências, a suspensão do ato ou do procedimento impugnado, até que o Tribunal decida sobre o mérito da questão suscitada, nos termos do art. 45 da Lei no 8.443 , de 1992.

$\S 1^{\circ} \mathrm{O}$ despacho do relator ou do Presidente, de que trata o caput, bem como a revisão da cautelar concedida, nos termos do $\S 5^{\circ}$ deste artigo, será submetido ao Plenário na primeira sessão subsequente.

$\S 2^{\circ}$ Se o Plenário, o Presidente ou o relator entender que antes de ser adotada a medida cautelar deva o responsável ser ouvido, o prazo para a resposta será de até cinco dias úteis.

$\S 3^{\circ}$ A decisão do Plenário, do Presidente ou do relator que adotar a medida cautelar determinará também a oitiva da parte, para que se pronuncie em até quinze dias, ressalvada a hipótese do parágrafo anterior.

$\S 4^{\circ}$ Nas hipóteses de que trata este artigo, as devidas notificações e demais comunicações do Tribunal e, quando for o caso, a resposta do responsável ou interessado poderão ser encaminhadas por telegrama, fac-símile ou outro meio eletrônico, sempre com confirmação de recebimento, com posterior remessa do original, no prazo de até cinco dias, iniciando-se a contagem do prazo a partir da mencionada confirmação do recebimento.

$\S 5^{\circ}$ A medida cautelar de que trata este artigo pode ser revista de ofício por quem a tiver adotado ou em resposta a requerimento da parte.

$\S 6^{\circ}$ Recebidas eventuais manifestações das partes quanto às oitivas a que se referem os parágrafos anteriores, deverá a unidade técnica submeter à apreciação do relator análise e proposta tão somente quanto aos fundamentos e à manutenção da cautelar, salvo quando o estado do processo permitir a formulação imediata da proposta de mérito. 


\section{TÍTULO IX \\ RECURSOS \\ CAPÍTULO I \\ DISPOSIÇÕES GERAIS}

Art. 277. Cabem os seguintes recursos nos processos do Tribunal:

I - recurso de reconsideração;

II - pedido de reexame;

III - embargos de declaração;

IV - recurso de revisão;

$\mathrm{V}$ - agravo.

Art. 278. O relator do recurso apreciará sua admissibilidade e fixará os itens do acórdão sobre os quais ele incide, na hipótese e para os fins do $\S 1^{\circ}$ do art. 285 , em prazo a ser definido em ato normativo, após exame preliminar da unidade técnica.

$\S 1^{\circ}$ Se o relator entender admissível o recurso, determinará as providências para sua instrução, saneamento e apreciação, bem como para comunicação aos órgãos ou entidades pertinentes, se houver efeito suspensivo.

$\S 2^{\circ}$ Entendendo não ser admissível, mesmo que por motivo decorrente de erro grosseiro, máfé ou atitude meramente protelatória, ou por estar prejudicado em razão da manifesta perda de seu objeto, o relator, ouvido o Ministério Público, quando cabível, não conhecerá do recurso mediante despacho fundamentado ou, a seu critério, submetê-lo-á ao colegiado.

$\S 3^{\circ} \mathrm{A}$ interposição de recurso, ainda que venha a não ser conhecido, gera preclusão consumativa.

$\S 4^{\circ}$ Não se conhecerá de recurso da mesma espécie, exceto embargos de declaração, pela parte ou pelo Ministério Público junto ao TCU, contra deliberação que apreciou o primeiro recurso interposto.

$\S 5^{\circ}$ Não se conhecerá de recurso contra deliberação proferida em sede de monitoramento de acórdão do Tribunal em que não tenham sido rediscutidas questões de mérito, nem imposto nenhum tipo de sanção.

Art. 279. Ressalvada a hipótese de embargos de declaração, não cabe recurso de decisão que rejeitar alegações de defesa, converter processo em tomada de contas especial ou determinar sua instauração, ou ainda que determinar a realização de citação, audiência, diligência ou fiscalização.

Parágrafo único. Se a parte intentar o recurso, a documentação encaminhada será aproveitada como defesa, sempre que possível, sem prejuízo da realização da citação ou da audiência, quando for obrigatória.

Art. 280. Exceto nos embargos de declaração, no agravo e no pedido de reexame em processo de fiscalização de ato ou contrato, é obrigatória a audiência do Ministério Público em todos os recursos, ainda que o recorrente tenha sido ele próprio.

$\S 1^{\circ} \mathrm{O}$ relator poderá deixar de encaminhar os autos ao Ministério Público, solicitando sua manifestação oral na sessão de julgamento quando, nos recursos, apresentar ao colegiado proposta de:

I - não conhecimento;

II - correção de erro material;

III - evidente conteúdo de baixa complexidade que não envolva o mérito.

$\S 2^{\circ}$ Entendendo conveniente, o representante do Ministério Público pedirá vista dos autos, que poderá ser em mesa, para oferecimento de manifestação na própria sessão de julgamento, ou em seu gabinete, para apresentação de parecer ao relator, no prazo de cinco dias úteis. 
$\S 3^{\circ}$ A manifestação oral do Ministério Público, nas hipóteses tratadas nos parágrafos anteriores, deverá ser reduzida a termo, assinada por seu representante e, no prazo de quarenta e oito horas após o encerramento da sessão, juntada aos autos.

Art. 281. Havendo mais de um responsável pelo mesmo fato, o recurso apresentado por um deles aproveitará a todos, mesmo àquele que houver sido julgado à revelia, no que concerne às circunstâncias objetivas, não aproveitando no tocante aos fundamentos de natureza exclusivamente pessoal.

Art. 282. Cabe ao interessado demonstrar, na peça recursal, em preliminar, o seu interesse em intervir no processo, nos termos do $\S 1^{\circ}$ do art. 146, devendo a questão ser avaliada no juízo de admissibilidade.

Art. 283. Nos recursos interpostos pelo Ministério Público, é necessária a instauração do contraditório, mediante concessão de oportunidade para oferecimento de contrarrazões recursais, quando se tratar de recurso tendente a agravar a situação do responsável.

Parágrafo único. O Tribunal regulamentará os recursos interpostos pelo Ministério Público, com observância ao disposto neste artigo.

Art. 284. Havendo partes com interesses opostos, a interposição de recurso por uma delas enseja à outra a apresentação de contrarrazões, no mesmo prazo dado ao recurso.

\section{CAPÍTULO II \\ RECURSO DE RECONSIDERAÇÃO}

Art. 285. De decisão definitiva em processo de prestação ou tomada contas, inclusive especial, cabe recurso de reconsideração, com efeito suspensivo, para apreciação do colegiado que houver proferido a decisão recorrida, podendo ser formulado uma só vez e por escrito, pela parte ou pelo Ministério Público junto ao Tribunal, dentro do prazo de quinze dias, contados na forma prevista no art. 183.

$\S 1^{\circ}$ Se o recurso versar sobre item específico do acórdão, os demais itens não recorridos não sofrem o efeito suspensivo, caso em que deverá ser constituído processo apartado para prosseguimento da execução das decisões.

$\S 2^{\circ}$ Não se conhecerá de recurso de reconsideração quando intempestivo, salvo em razão de superveniência de fatos novos e dentro do período de cento e oitenta dias contados do término do prazo indicado no caput, caso em que não terá efeito suspensivo.

\section{CAPÍTULO III PEDIDO DE REEXAME}

Art. 286. Cabe pedido de reexame de decisão de mérito proferida em processo concernente a ato sujeito a registro e a fiscalização de atos e contratos.

Parágrafo único. Ao pedido de reexame aplicam-se as disposições do caput e dos parágrafos do art. 285.

\section{CAPÍTULO IV \\ EMBARGOS DE DECLARAÇÃO}

Art. 287. Cabem embargos de declaração quando houver obscuridade, omissão ou contradição em acórdão do Tribunal. 
$\S 1^{\circ}$ Os embargos de declaração poderão ser opostos por escrito pela parte ou pelo Ministério Público junto ao Tribunal, dentro do prazo de dez dias, contados na forma prevista no art. 183, com indicação do ponto obscuro, contraditório ou omisso.

$\S 2^{\circ}$ Os embargos de declaração serão submetidos à deliberação do colegiado competente pelo relator ou pelo redator, conforme o caso.

$\S 3^{\circ}$ Os embargos de declaração suspendem os prazos para cumprimento do acórdão embargado e para interposição dos demais recursos previstos neste Regimento, aplicando-se, entretanto, o disposto no $\S 1^{\circ}$ do art. 285.

$\S 4^{\circ}$ Interpostos embargos de declaração contra acórdão proferido em processo relatado por ministro-substituto convocado, este permanece vinculado ao respectivo processo.

$\S 5^{\circ}$ Ao apreciar embargos de declaração opostos contra decisão proferida por câmara que deixou de integrar, o ministro, excepcionalmente, relatará o processo e proferirá o seu voto na câmara de origem.

$\S 6^{\circ}$ Os embargos de declaração meramente protelatórios serão recebidos como petição, por meio de despacho do relator, não se lhes aplicando o disposto no $\S 3^{\circ}$ deste artigo.

$\S 7^{\circ}$ Conferidos efeitos infringentes aos embargos, serão devolvidos os prazos a todos os interessados.

\section{CAPÍTULO V \\ RECURSO DE REVISÃO}

Art. 288. De decisão definitiva em processo de prestação ou tomada de contas, inclusive especial, cabe recurso de revisão ao Plenário, de natureza similar à da ação rescisória, sem efeito suspensivo, interposto uma só vez e por escrito pelo responsável, seus sucessores, ou pelo Ministério Público junto ao Tribunal, dentro do prazo de cinco anos, contados na forma prevista no inciso IV do art. 183, e fundar-se-á:

I - em erro de cálculo nas contas;

II - em falsidade ou insuficiência de documentos em que se tenha fundamentado o acórdão recorrido;

III - na superveniência de documentos novos com eficácia sobre a prova produzida.

$\S 1^{\circ} \mathrm{O}$ acórdão que der provimento a recurso de revisão ensejará a correção de todo e qualquer erro ou engano apurado.

$\S 2^{\circ}$ Em face de indícios de elementos eventualmente não examinados pelo Tribunal, o Ministério Público poderá interpor recurso de revisão, compreendendo o pedido de reabertura as contas e o pedido de mérito.

$\S 3^{\circ}$ Admitido o pedido de reabertura das contas pelo relator sorteado para o recurso de revisão, este ordenará, por despacho, sua instrução pela unidade técnica competente e a conseguinte instauração de contraditório, se apurados elementos que conduzam ao agravamento da situação do responsável ou à inclusão de novos responsáveis.

$\S 4^{\circ}$ A instrução do recurso de revisão abrange o reexame de todos os elementos constantes dos autos.

$\S 5^{\circ} \mathrm{A}$ interposição de recurso de revisão pelo Ministério Público dar-se-á em petição autônoma para cada processo de contas a ser reaberto.

$\S 6^{\circ}$ Se os elementos que deram ensejo ao recurso de revisão referirem-se a mais de um exercício, os respectivos processos serão conduzidos por um único relator, sorteado para o recurso. 


\section{CAPÍTULO VI \\ AGRAVO}

Art. 289. De despacho decisório do Presidente do Tribunal, de presidente de câmara ou do relator, desfavorável à parte, e da medida cautelar adotada com fundamento no art. 276 cabe agravo, no prazo de cinco dias, contados na forma do art. 183.

$\S 1^{\circ}$ Interposto o agravo, o Presidente do Tribunal, o presidente de câmara ou o relator poderá reformar o seu despacho ou submeter o feito à apreciação do colegiado competente para o julgamento de mérito do processo.

$\S 2^{\circ} \mathrm{Se}$ o despacho agravado for do Presidente do Tribunal ou de presidente de câmara, o julgamento será, nos termos deste Regimento, presidido por seu substituto, computando-se o voto do presidente agravado.

$\S 3^{\circ}$ Caso a decisão agravada seja do Tribunal, o relator do agravo será o mesmo que já atuava no processo ou o redator do acórdão recorrido, se este houver sido o autor da proposta de medida cautelar.

$\S 4^{\circ}$ A critério do Presidente do Tribunal, do presidente de câmara ou do relator, conforme o caso, poderá ser conferido efeito suspensivo ao agravo.

$\S 5^{\circ}$ Interposto agravo contra acórdão proferido em processo relatado por ministro-substituto convocado, este permanece vinculado ao respectivo processo.

\section{TÍTULO X \\ FIXAÇÃO DOS COEFICIENTES DE PARTICIPAÇÕES CONSTITUCIONAIS}

Art. 290. O Tribunal, até o último dia útil de cada exercício, fixará e publicará os coeficientes individuais de participação dos estados, do Distrito Federal e dos municípios, no Fundo de Participação dos Estados e do Distrito Federal (FPE), e no Fundo de Participação dos Municípios (FPM), para vigorarem no exercício subsequente.

Parágrafo único. Os coeficientes individuais de participação serão calculados na forma e critérios fixados em lei e com base em dados constantes da relação que deverá ser encaminhada ao Tribunal até 31 de outubro de cada ano pela Fundação Instituto Brasileiro de Geografia e Estatística - IBGE.

Art. 291. O Tribunal, até o último dia útil do mês de julho de cada ano, aprovará e publicará nos órgãos oficiais os coeficientes individuais de participação dos estados e do Distrito Federal nos recursos de que trata o inciso II do art. 159 da Constituição Federal, calculados de acordo com critérios fixados em lei.

Parágrafo único. Até o dia 25 do mês de julho de cada ano, o órgão encarregado do controle das exportações de produtos industrializados fornecerá ao Tribunal, de forma consolidada e por unidade da federação, os valores das exportações ocorridas nos doze meses antecedentes a $1^{\circ}$ de julho do ano imediatamente anterior, apurados na forma da lei.

Art. 292. As unidades federadas disporão de trinta dias, a partir da publicação referida nos arts. 290 e 291, para apresentar contestação, juntando desde logo as provas em que se fundamentar. Parágrafo único. O Tribunal deverá manifestar-se sobre a contestação mencionada neste artigo no prazo de trinta dias, contados da data do seu recebimento.

Art. 292-A. As Unidades Federadas disporão de quinze dias, a partir da publicação dos percentuais individuais de participação calculados pelo Tribunal por força do disposto no caput do $\S 4^{\circ}$ do art. $1^{\circ}$-A e no $\S 2^{\circ}$ do art. $1^{\circ}$-B da Lei $n^{\circ} 10.336$, de 19 de dezembro de 2001, acrescidos pela Lei $\mathrm{n}^{\circ} 10.866$, de 4 de maio de 2004, para apresentar o recurso para retificação previsto no $\S 5^{\circ}$ do art. $1^{\circ}$-A do mesmo diploma legal.

Parágrafo único. O Tribunal se manifestará sobre o recurso mencionado neste artigo dentro do 
prazo previsto no inciso III do $\S 4^{\circ}$ do art. $1^{\circ}$-A da Lei ${ }^{\circ}$ 10.336/2001.

\section{TÍTULO XI DISPOSIÇÕES GERAIS}

Art. 293. O Tribunal de Contas da União encaminhará ao Congresso Nacional, trimestral e anualmente, relatório de suas atividades.

$\S 1^{\circ}$ Os relatórios trimestrais e anuais serão encaminhados pelo Tribunal ao Congresso Nacional nos prazos de até sessenta dias e de até noventa dias, respectivamente, após o vencimento dos períodos correspondentes.

$\S 2^{\circ}$ Os relatórios conterão, além de outros elementos, a resenha das atividades específicas no tocante ao julgamento de contas e à apreciação de processos de fiscalização a cargo do Tribunal. Art. 294. As atas das sessões do Tribunal serão publicadas nos órgãos oficiais, conforme disposto em ato normativo específico, e terão os efeitos de prova hábil para todos os fins de direito.

Art. 295. O Tribunal terá as seguintes publicações:

I - atas das sessões plenárias e das câmaras;

II - Boletim do Tribunal de Contas da União;

III - Revista do Tribunal de Contas da União;

IV - Súmula da Jurisprudência;

$\mathrm{V}$ - Regimento Interno.

$\S 1^{\circ} \mathrm{O}$ Tribunal poderá ter, ainda, outras publicações relativas às matérias de sua competência. $\S 2^{\circ}$ No começo de cada ano, desde que tenha havido anteriormente reforma regimental, será republicado, na íntegra, o Regimento Interno.

$\S 3^{\circ} \mathrm{O}$ Boletim do Tribunal de Contas da União é considerado órgão oficial, nos termos do art. 98 da Lei $\mathrm{n}^{\circ} 8.443$, de 1992.

$\S 4^{\circ}$ O Tribunal poderá criar diário eletrônico, disponibilizado no Portal do TCU, para publicação de atos processuais e administrativos próprios, bem como comunicações em geral, consoante o disposto no art. $4^{\circ}$ da Lei 11.419, de 19 de dezembro de 2006.

$\S 5^{\circ}$ A publicação no diário eletrônico substituirá qualquer outro meio e publicação oficial, para quaisquer efeitos legais, à exceção dos casos expressamente estabelecidos em lei.

Art. 296. O Tribunal de Contas da União poderá firmar acordo de cooperação com os tribunais de contas dos estados, do Distrito Federal, com os conselhos ou tribunais de contas dos municípios, com tribunais nacionais e entidades congêneres internacionais, com outros órgãos e entidades da administração pública e, ainda, com entidades civis, objetivando o intercâmbio de informações que visem ao aperfeiçoamento dos sistemas de controle e de fiscalização, o treinamento e o aperfeiçoamento de pessoal e o desenvolvimento de ações conjuntas de fiscalização quando envolverem o mesmo órgão ou entidade repassadora ou aplicadora dos recursos públicos, observadas a jurisdição e a competência específica de cada participante.

$\S 1^{\circ}$ Os acordos de cooperação aprovados pelo Plenário serão assinados pelo Presidente do Tribunal.

$\S 2^{\circ}$ No caso de ser instituída comissão para implantar acordo de cooperação, o Presidente designará ministros ou auditores para integrá-la, na forma estabelecida em ato normativo.

$\S 3^{\circ} \mathrm{O}$ Plenário poderá delegar ao Presidente a competência para aprovar os acordos de cooperação de que trata o caput, nos termos e limites que estabelecer no ato de delegação.

Art. 297. O Tribunal, para o exercício de sua competência institucional, poderá, na forma estabelecida em ato normativo, requisitar aos órgãos e entidades federais, sem quaisquer ônus, a prestação de serviços técnicos especializados, a serem executados por prazo previamente 
fixado, sob pena de aplicação da sanção prevista no inciso VII do art. 268, de acordo com o art. 101 da Lei $\mathrm{n}^{\circ} 8.443$, de 1992.

Art. 298. Aplicam-se subsidiariamente no Tribunal as disposições das normas processuais em vigor, no que couber e desde que compatíveis com a Lei Orgânica.

Art. 298-A. Todos os atos, os termos, os documentos, as comunicações e as deliberações poderão ser produzidas, praticados, armazenados, transmitidos e assinados em meio eletrônico, na forma de norma elaborada pelo Tribunal, atendidos os requisitos previstos em lei.

Art. 298-B. O Tribunal presta homenagem aos ministros:

I - por motivo de afastamento definitivo de seu serviço;

II - por motivo de falecimento;

III - para celebrar o centenário de nascimento.

$\S 1^{\circ}$ As sessões comemorativas de celebração de centenário de nascimento serão realizadas, sempre que possível, na primeira parte da sessão do Plenário que ocorrer na quarta-feira seguinte à data natalícia que se estiver celebrando.

$\S 2^{\circ}$ Quando a homenagem consistir na aposição de nome, busto ou estátua em dependência do Tribunal, dependerá de proposta escrita e justificada de pelo menos cinco ministros, sobre a qual opinará, fundamentalmente, o Presidente, e de aprovação do Plenário, por maioria absoluta de votos.

Art. 299. Este Regimento Interno entrará em vigor em $1^{\text {o }}$ de janeiro de 2003. 
ANEXO IV

Amostra 1 - Coefficients ${ }^{a}$

\begin{tabular}{|l|r|r|r|r|r|}
\hline \multirow{2}{*}{ Model } & \multicolumn{2}{|c|}{ Unstandardized Coefficients } & \multicolumn{1}{c|}{$\begin{array}{c}\text { Standardized } \\
\text { Coefficients }\end{array}$} & \multicolumn{1}{c|}{ Sig. } \\
\cline { 2 - 5 } & \multicolumn{1}{|c|}{$\mathrm{B}$} & \multicolumn{1}{c|}{ Std. Error } & \multicolumn{1}{c|}{ Beta } & \\
\hline (Constant) & $-24562,813$ & 20856,835 & & $-1,178$ &, 240 \\
SeHouverRecurso & $-13082,202$ & 12748,764 &,- 044 & $-1,026$ &, 306 \\
Convênio & 17674,940 & 9609,148 &, 078 & 1,839 &, 067 \\
Montate_Débito &, 112 &, 008 &, 628 & 14,795 &, 000 \\
Montante do Processo & $-2,448 \mathrm{E}-005$ &, 000 &,- 005 &,- 109 &, 913 \\
Avaliado & $-1238,069$ & 10506,971 &,- 005 &,- 118 &, 906 \\
Débito Solidário & & & &
\end{tabular}

a. Dependent Variable: Multa relacionada ao artigo 57

Amostra 2 - Coefficients ${ }^{a}$

\begin{tabular}{|c|c|c|c|c|c|c|}
\hline \multirow[t]{2}{*}{ Model } & & \multicolumn{2}{|c|}{ Unstandardized Coefficients } & \multirow{2}{*}{$\begin{array}{c}\begin{array}{c}\text { Standardized } \\
\text { Coefficients }\end{array} \\
\text { Beta }\end{array}$} & \multirow[t]{2}{*}{$\mathrm{t}$} & \multirow[t]{2}{*}{ Sig. } \\
\hline & & $B$ & Std. Error & & & \\
\hline \multirow{6}{*}{1} & (Constant) & 22477,606 & 5694,565 & & 3,947 & ,000 \\
\hline & $\begin{array}{l}\text { SeHouveRec } \\
\text { urso }\end{array}$ & $-5927,833$ & 3250,986 &,- 088 & $-1,823$ & ,069 \\
\hline & Convênio & $-1943,302$ & 2750,134 &,- 033 &,- 707 & ,480 \\
\hline & $\begin{array}{l}\text { Montante do } \\
\text { Débito }\end{array}$ & ,010 & ,001 & ,436 & 9,182 & ,000 \\
\hline & $\begin{array}{l}\text { Montante do } \\
\text { Processo } \\
\text { Avaliado }\end{array}$ & $-7,011 E-005$ & ,000 &,- 036 &,- 755 & ,451 \\
\hline & $\begin{array}{l}\text { Débito } \\
\text { Solidário }\end{array}$ & $-5378,942$ & 2935,216 &,- 089 & $-1,833$ & ,068 \\
\hline
\end{tabular}

a. Dependent Variable: Multa relacionada ao artigo 57

Amostra 1 - Coefficients ${ }^{a}$

\begin{tabular}{|c|c|c|c|c|c|}
\hline \multirow[t]{2}{*}{ Model } & \multicolumn{2}{|c|}{ Unstandardized Coefficients } & \multirow{2}{*}{\begin{tabular}{|c|}
$\begin{array}{c}\text { Standardized } \\
\text { Coefficients }\end{array}$ \\
Beta
\end{tabular}} & \multirow[t]{2}{*}{$\mathrm{t}$} & \multirow[t]{2}{*}{ Sig. } \\
\hline & $\mathrm{B}$ & Std. Error & & & \\
\hline (Constant) & 16,601 & 4,401 & & 3,773 &, 000 \\
\hline Se Houver Recurso & $-2,847$ & 2,785 &,- 061 & $-1,023$ & ,307 \\
\hline Convênio & 2,373 & 2,060 & ,069 & 1,152 & ,250 \\
\hline Montate_Débito & $-6,325 E-006$ &, 000 &,- 251 & $-2,870$ & ,004 \\
\hline $\begin{array}{l}\text { Montante do } \\
\text { Processo } \\
\text { Avaliado }\end{array}$ & $6,761 \mathrm{E}-007$ & ,000 &, 117 & 1,343 & ,180 \\
\hline Débito Solidário & $-1,032$ & 2,167 &,- 029 &,- 476 & ,634 \\
\hline
\end{tabular}

a. Dependent Variable: Porcentagem da multa do art. 57 em relação ao montante do débito 
Amostra 2 - Coefficients ${ }^{a}$

\begin{tabular}{|c|c|c|c|c|c|}
\hline \multirow[t]{2}{*}{ Model } & \multicolumn{2}{|c|}{ Unstandardized Coefficients } & \multirow{2}{*}{$\begin{array}{c}\text { Standardized } \\
\text { Coefficients } \\
\text { Beta }\end{array}$} & \multirow[t]{2}{*}{$\mathrm{T}$} & \multirow[t]{2}{*}{ Sig. } \\
\hline & $B$ & Std. Error & & & \\
\hline (Constant) & 18,801 & 3,593 & & 5,233 & ,000 \\
\hline Se Houve Recurso & $-2,285$ & 2,211 &,- 064 & $-1,033$ & ,302 \\
\hline Convênio & $-1,336$ & 1,833 &,- 044 &,- 729 & ,467 \\
\hline Montante do Débito & -1,567E-006 &, 000 &,- 166 & $-2,660$ & ,008 \\
\hline $\begin{array}{l}\text { Montante do Processo } \\
\text { Avaliado }\end{array}$ & $-1,048 \mathrm{E}-007$ &, 000 &,- 080 & $-1,281$ & ,201 \\
\hline Débito Solidário &,- 076 & 1,759 &,- 003 &,- 043 & ,966 \\
\hline
\end{tabular}

a. Dependent Variable: Porcentagem da multa do art. 57 em relação ao montante do débito

Amostra 1 - Coefficients ${ }^{a}$

\begin{tabular}{|c|c|c|c|c|c|c|}
\hline \multirow{2}{*}{\multicolumn{2}{|c|}{ Model }} & \multicolumn{2}{|c|}{ Unstandardized Coefficients } & \multirow{2}{*}{$\begin{array}{c}\text { Standardized } \\
\text { Coefficients } \\
\text { Beta }\end{array}$} & \multirow[t]{2}{*}{$\mathrm{T}$} & \multirow[t]{2}{*}{ Sig. } \\
\hline & & $B$ & Std. Error & & & \\
\hline \multirow{6}{*}{1} & (Constant) & 1676,366 & 546,806 & & 3,066 & ,002 \\
\hline & Se Houver Recurso & $-31,506$ & 334,236 &,- 005 &,- 094 & 925 \\
\hline & Convênio & $-111,101$ & 251,924 &,- 024 &,- 441 & 659 \\
\hline & Montate_Débito &, 000 &, 000 &,- 091 & $-1,678$ & ,094 \\
\hline & $\begin{array}{l}\text { Montante do } \\
\text { Processo Avaliado }\end{array}$ & $1,019 E-005$ & ,000 & ,094 & 1,730 & ,084 \\
\hline & Débito Solidário & $-642,653$ & 275,462 &,- 128 & $-2,333$ & ,020 \\
\hline
\end{tabular}

a. Dependent Variable: Multa relacionada ao artigo 58

Amostra 2 - Coefficients ${ }^{a}$

\begin{tabular}{|l|r|r|r|r|r|}
\hline Model & \multicolumn{2}{|c|}{ Unstandardized Coefficients } & \multicolumn{1}{c|}{$\begin{array}{c}\text { Standardized } \\
\text { Coefficients }\end{array}$} & \multirow{2}{*}{ Sig. } \\
\cline { 2 - 5 } & \multicolumn{1}{|c|}{$\mathrm{B}$} & Std. Error & Beta & 2,465 &, 014 \\
\hline & 1539,685 & 624,567 &, 114 & 2,213 &, 028 \\
(Constant) & 789,144 & 356,561 &, 095 & 1,900 &, 058 \\
SeHouveRecurso & 573,225 & 301,628 &,- 089 & $-1,755$ &, 080 \\
Convênio &, 000 &, 000 &, 183 & 3,640 &, 000 \\
Montante do Débito & $3,707 \mathrm{E}-005$ &, 000 &,- 186 & $-3,616$ &, 000 \\
\hline
\end{tabular}

a. Dependent Variable: Multa relacionada ao artigo 58 
Amostra 1 - Coefficients ${ }^{a}$

\begin{tabular}{|c|c|c|c|c|c|}
\hline \multirow[t]{2}{*}{ Model } & \multicolumn{2}{|c|}{ Unstandardized Coefficients } & \multirow{2}{*}{$\begin{array}{c}\text { Standardized } \\
\text { Coefficients } \\
\text { Beta }\end{array}$} & \multirow[t]{2}{*}{$\mathrm{T}$} & \multirow[t]{2}{*}{ Sig. } \\
\hline & $\mathrm{B}$ & Std. Error & & & \\
\hline (Constant) & 28,536 & 9,926 & & 2,875 & ,006 \\
\hline Se Houver Recurso & $-3,984$ & 5,328 &,- 119 &,- 748 & ,459 \\
\hline Convênio & $-4,408$ & 4,346 &,- 158 & $-1,014$ & ,317 \\
\hline Montate_Débito & $-1,872 \mathrm{E}-006$ &, 000 &,- 021 &,- 133 & ,895 \\
\hline $\begin{array}{l}\text { Montante do Processo } \\
\text { Avaliado }\end{array}$ & 7,124E-009 &, 000 & ,028 &, 180 & ,858 \\
\hline Débito Solidário & $-6,637$ & 6,085 &,- 173 & $-1,091$ & ,282 \\
\hline
\end{tabular}

a. Dependent Variable: Porcentagem_MultaArt58

Asmotra 2 - Coefficients ${ }^{a}$

\begin{tabular}{|l|r|r|r|r|r|}
\hline \multirow{2}{*}{ Model } & \multicolumn{2}{|c|}{ Unstandardized Coefficients } & \multicolumn{1}{c|}{$\begin{array}{c}\text { Standardized } \\
\text { Coefficients }\end{array}$} & Sig. \\
\cline { 2 - 5 } & \multicolumn{1}{|c|}{$\mathrm{B}$} & Std. Error & \multicolumn{1}{c|}{ Beta } & \\
\hline (Constant) & 17,782 & 9,384 & &, 063 \\
Se Houve Recurso &,-- 957 & 3,324 &,- 035 &,- 288 &, 774 \\
Convênio & 2,363 & 3,347 &, 089 &, 706 &, 483 \\
Montante do Débito & $-6,057 \mathrm{E}-007$ &, 000 &,- 020 &,- 158 &, 875 \\
Montante do Processo & $8,267 \mathrm{E}-008$ &, 000 &, 157 & 1,280 &, 205 \\
Avaliado & $-7,119$ & 6,906 &,- 127 & $-1,031$ &, 306 \\
Débito Solidário & & & & \\
\hline
\end{tabular}

a. Dependent Variable: Porcentagem_MultaArt58 
ANEXO V

Regressões Lineares da Multa do Art. 58

Amostra 1 - Coefficients ${ }^{a}$

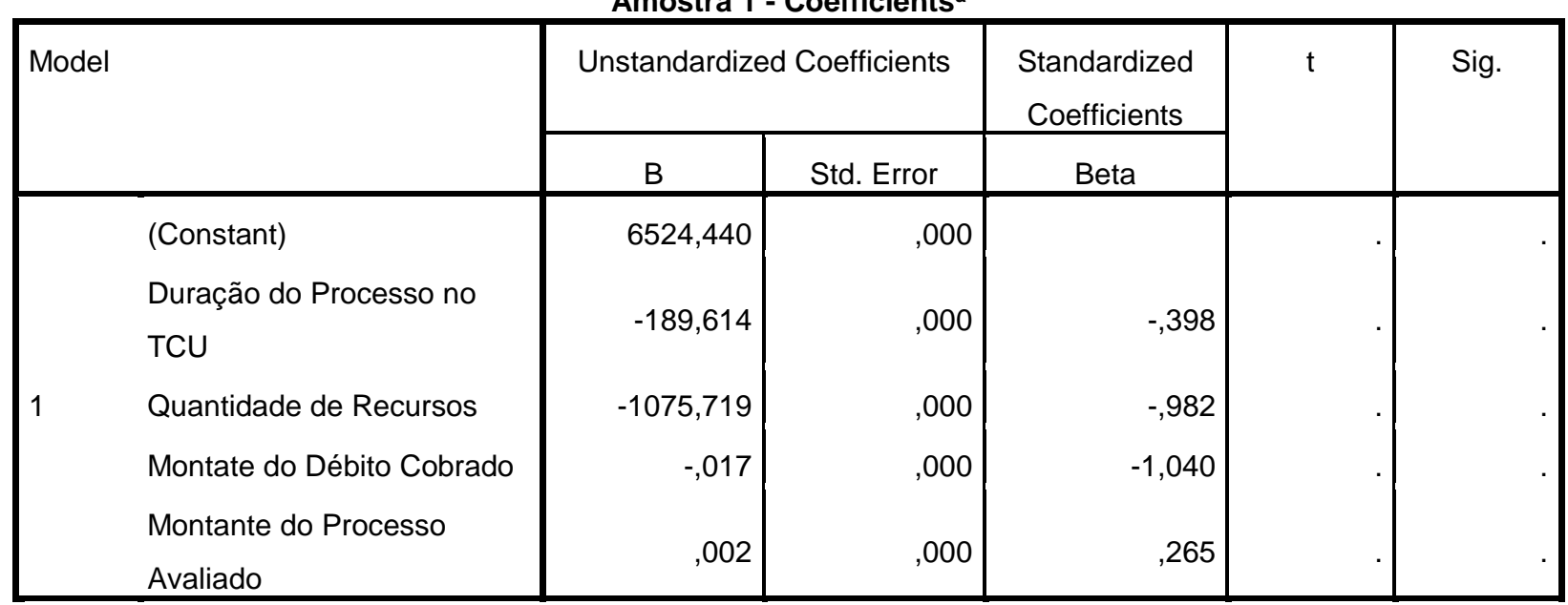

a. Dependent Variable: Multa relacionada ao artigo 58

Amostra 2 - Coefficients ${ }^{a}$

\begin{tabular}{|c|c|c|c|c|c|c|}
\hline \multirow{2}{*}{\multicolumn{2}{|c|}{ Model }} & \multicolumn{2}{|c|}{ Unstandardized Coefficients } & \multirow{2}{*}{$\begin{array}{c}\text { Standardized } \\
\text { Coefficients } \\
\text { Beta } \\
\end{array}$} & \multirow[t]{2}{*}{$\mathrm{t}$} & \multirow[t]{2}{*}{ Sig. } \\
\hline & & $\mathrm{B}$ & Std. Error & & & \\
\hline \multirow{5}{*}{1} & (Constant) & 1253,799 & 1590,198 & & ,788 &, 575 \\
\hline & $\begin{array}{l}\text { Duração do Processo no } \\
\text { TCU }\end{array}$ & 797,133 & 415,841 & 1,763 & 1,917 & ,306 \\
\hline & Quantidade de Recursos & 754,227 & 986,300 &, 377 & ,765 &, 584 \\
\hline & $\begin{array}{l}\text { Montante do Processo } \\
\text { Avaliado }\end{array}$ & ,000 &, 000 &,- 950 & $-1,157$ & ,454 \\
\hline & Montante do Débito & $-9,298 E-005$ &, 001 &,- 033 &,- 067 & ,957 \\
\hline
\end{tabular}

a. Dependent Variable: Multa relacionada ao artigo 58 
Amostra 1 - Coefficients ${ }^{a}$

\begin{tabular}{|c|c|c|c|c|c|c|}
\hline \multirow{2}{*}{\multicolumn{2}{|c|}{ Model }} & \multicolumn{2}{|c|}{ Unstandardized Coefficients } & \multirow{2}{*}{$\begin{array}{c}\text { Standardized } \\
\text { Coefficients } \\
\text { Beta }\end{array}$} & \multirow[t]{2}{*}{$\mathrm{t}$} & \multirow[t]{2}{*}{ Sig. } \\
\hline & & $\mathrm{B}$ & Std. Error & & & \\
\hline \multirow{3}{*}{1} & (Constant) & 6346,154 & 1239,432 & & 5,120 &, 000 \\
\hline & $\begin{array}{l}\text { Cargo de Perfeito e } \\
\text { Secretário }\end{array}$ & $-2754,487$ & 1626,550 &,- 302 & $-1,693$ & ,098 \\
\hline & $\begin{array}{l}\text { Cargo de Presidente e } \\
\text { Diretor }\end{array}$ & $-730,769$ & 1752,822 &,- 074 &,- 417 & ,679 \\
\hline \multirow{3}{*}{1} & (Constant) & 5615,385 & 1239,432 & & 4,531 &, 000 \\
\hline & $\begin{array}{l}\text { Cargo de Perfeito e } \\
\text { Secretário }\end{array}$ & $-2023,718$ & 1626,550 &,- 222 & $-1,244$ & ,221 \\
\hline & Outras Cargos & 730,769 & 1752,822 &, 074 & ,417 & 679 \\
\hline
\end{tabular}

a. Dependent Variable: Multa relacionada ao artigo 58

Amostra 2 - Coefficients ${ }^{a}$

\begin{tabular}{|c|c|c|c|c|c|c|}
\hline \multirow{2}{*}{\multicolumn{2}{|c|}{ Model }} & \multicolumn{2}{|c|}{ Unstandardized Coefficients } & \multirow{2}{*}{$\begin{array}{c}\text { Standardized } \\
\text { Coefficients } \\
\text { Beta }\end{array}$} & \multirow[t]{2}{*}{$\mathrm{t}$} & \multirow[t]{2}{*}{ Sig. } \\
\hline & & $\mathrm{B}$ & Std. Error & & & \\
\hline \multirow{3}{*}{1} & (Constant) & 5586,957 & 994,733 & & 5,617 &, 000 \\
\hline & $\begin{array}{l}\text { Cargo de Prefeito e } \\
\text { Secretário }\end{array}$ & $-348,364$ & 1353,660 &,- 037 &,- 257 & ,798 \\
\hline & $\begin{array}{l}\text { Cargo de Presidente e } \\
\text { Direto }\end{array}$ & $-1071,332$ & 1553,026 &,- 098 &,- 690 & ,493 \\
\hline \multirow{3}{*}{1} & (Constant) & 4515,625 & 1197,647 & & 3,770 &, 000 \\
\hline & $\begin{array}{l}\text { Cargo de Prefeito e } \\
\text { Secretário }\end{array}$ & 847,528 & 1522,183 &, 088 &, 557 &, 580 \\
\hline & Outros Cargos & 1071,332 & 1559,542 &, 109 & ,687 & ,495 \\
\hline
\end{tabular}

a. Dependent Variable: Multa relacionada ao artigo 58 
Amostra 1 - Coefficients ${ }^{a}$

\begin{tabular}{|c|c|c|c|c|c|c|}
\hline \multirow{2}{*}{\multicolumn{2}{|c|}{ Model }} & \multicolumn{2}{|c|}{ Unstandardized Coefficients } & \multirow{2}{*}{$\begin{array}{c}\begin{array}{c}\text { Standardized } \\
\text { Coefficients }\end{array} \\
\text { Beta } \\
\end{array}$} & \multirow[t]{2}{*}{$\mathrm{t}$} & \multirow[t]{2}{*}{ Sig. } \\
\hline & & $\mathrm{B}$ & Std. Error & & & \\
\hline \multirow{5}{*}{1} & (Constant) & 3590,909 & 1290,162 & & 2,783 & ,008 \\
\hline & Alínea_A & 209,091 & 2307,913 &, 014 &, 091 & ,928 \\
\hline & Alínea_B & 1822,727 & 1489,751 & ,214 & 1,224 & ,227 \\
\hline & Alínea_C & 2009,091 & 2307,913 &, 138 & ,871 & ,388 \\
\hline & Alínea_D & $-1590,909$ & 4469,254 &,- 051 &,- 356 & ,723 \\
\hline \multirow{5}{*}{1} & (Constant) & 3800,000 & 1913,620 & & 1,986 & ,053 \\
\hline & Alínea_B & 1613,636 & 2053,480 & , 189 & ,786 & ,436 \\
\hline & Alínea_C & 1800,000 & 2706,267 &, 124 & ,665 &, 509 \\
\hline & Alínea_D & $-1800,000$ & 4687,393 &,- 058 &,- 384 & ,703 \\
\hline & MaisDeUmAto & $-209,091$ & 2307,913 &,- 020 &,- 091 & ,928 \\
\hline \multirow{5}{*}{1} & (Constant) & 5413,636 & 744,876 & & 7,268 &, 000 \\
\hline & Alínea_C & 186,364 & 2053,480 & ,013 &, 091 & ,928 \\
\hline & Alínea_D & $-3413,636$ & 4343,334 &,- 109 &,- 786 & ,436 \\
\hline & MaisDeUmAto & $-1822,727$ & 1489,751 &,- 175 & $-1,224$ & ,227 \\
\hline & Alínea_A & $-1613,636$ & &,- 111 &,- 786 & ,436 \\
\hline \multirow{5}{*}{1} & (Constant) & 5600,000 & 1913,620 & & 2,926 & ,005 \\
\hline & Alínea_D & $-3600,000$ & 4687,393 &,- 115 &,- 768 & ,446 \\
\hline & MaisDeUmAto & $-2009,091$ & 2307,913 &,- 192 &,- 871 & ,388 \\
\hline & Alínea_A & $-1800,000$ & 2706,267 &,- 124 &,- 665 &, 509 \\
\hline & Alínea_B & $-186,364$ & 2053,480 &,- 022 &,- 091 & ,928 \\
\hline
\end{tabular}

a. Dependent Variable: Multa relacionada ao artigo 58 
Amostra 2 - Coefficients ${ }^{a}$

\begin{tabular}{|c|c|c|c|c|c|c|}
\hline \multirow{2}{*}{\multicolumn{2}{|c|}{ Model }} & \multicolumn{2}{|c|}{ Unstandardized Coefficients } & \multirow{2}{*}{$\begin{array}{c}\text { Standardized } \\
\text { Coefficients } \\
\text { Beta }\end{array}$} & \multirow[t]{2}{*}{$\mathrm{t}$} & \multirow[t]{2}{*}{ Sig. } \\
\hline & & $\mathrm{B}$ & Std. Error & & & \\
\hline \multirow{5}{*}{1} & (Constant) & 4846,154 & 1295,744 & & 3,740 &, 000 \\
\hline & Alínea_A & $-2596,154$ & 3548,541 &,- 095 &,- 732 & ,467 \\
\hline & Alínea_B & 739,542 & 1467,460 &, 077 &, 504 & ,616 \\
\hline & Alínea_C & $-96,154$ & 2099,345 &,- 007 &,- 046 & ,964 \\
\hline & Alínea_D & $-3096,154$ & 4848,230 &,- 081 &,- 639 &, 525 \\
\hline \multirow{5}{*}{1} & (Constant) & 2250,000 & 3303,512 & & ,681 & ,498 \\
\hline & Alínea_B & 3335,695 & 3374,563 & ,347 & ,988 & ,327 \\
\hline & Alínea_C & 2500,000 & 3693,439 &, 174 & 677 &, 501 \\
\hline & Alínea_D & $-500,000$ & 5721,851 &,- 013 &,- 087 & ,931 \\
\hline & MaisDeUmAto & 2596,154 & 3548,541 & ,221 & ,732 & ,467 \\
\hline \multirow{5}{*}{1} & (Constant) & 5585,695 & 688,830 & & 8,109 &, 000 \\
\hline & Alínea_C & $-835,695$ & 1789,632 &,- 058 &,- 467 & ,642 \\
\hline & Alínea_D & $-3835,695$ & 4722,380 &,- 100 &,- 812 & ,420 \\
\hline & MaisDeUmAto & $-739,542$ & 1467,460 &,- 063 &,- 504 & ,616 \\
\hline & Alínea_A & $-3335,695$ & 3374,563 &,- 122 &,- 988 & ,327 \\
\hline \multirow{5}{*}{1} & (Constant) & 4750,000 & 1651,756 & & 2,876 & ,005 \\
\hline & Alínea_D & $-3000,000$ & 4955,268 &,- 078 &,- 605 & ,547 \\
\hline & MaisDeUmAto & 96,154 & 2099,345 & ,008 &, 046 & ,964 \\
\hline & Alínea_A & $-2500,000$ & 3693,439 &,- 091 &,- 677 &, 501 \\
\hline & Alínea_B & 835,695 & 1789,632 & ,087 & ,467 & ,642 \\
\hline
\end{tabular}

a. Dependent Variable: Multa relacionada ao artigo 58 